\title{
Groundwater Regulation in a Drying South West
}

Michael Bennett and Alex Gardner

Faculty of Law, The University of Western Australia 
ISBN: 978-1-74052-306-6

\section{NATIONAL CENTRE FOR}

\section{GROUNDWATER RESEARCH \& TRAINING}

GPO Box 2100 | ADELAIDE SA $5001 \mid$ Australia

p: +61 882012193 | f: +61 882017906

enquiries@groundwater.com.au

www.groundwater.com.au

The National Centre for Groundwater Research and Training is an Australian Government initiative, supported by the Australian Research Council and the National Water Commission. 


\section{Contents}

Preface.

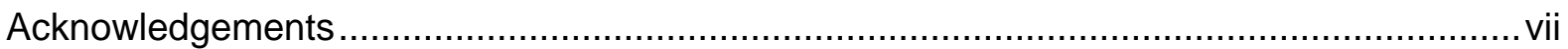

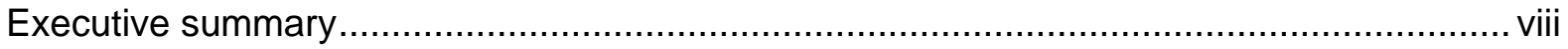

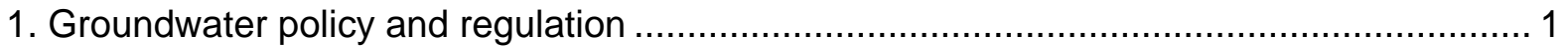

1.1 Policy objectives for groundwater management ..................................................... 1

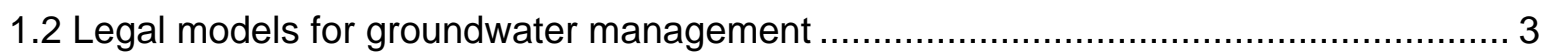

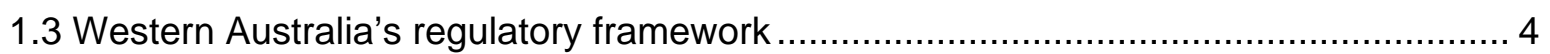

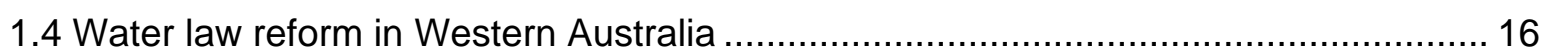

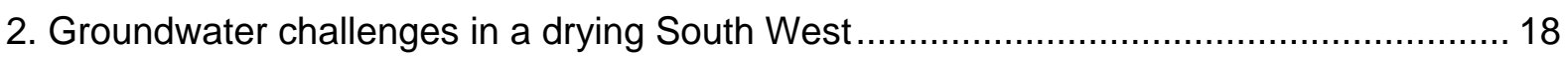

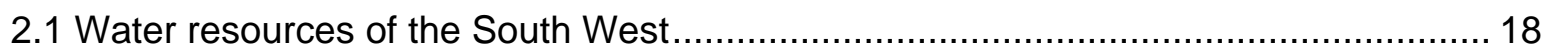

2.2 The drying trend and its impacts on water resources ....................................... 20

2.3 Future scenarios for groundwater in the South West ........................................... 29

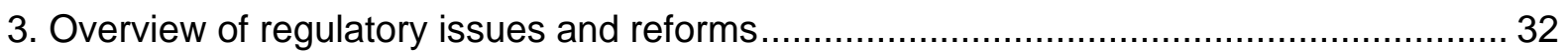

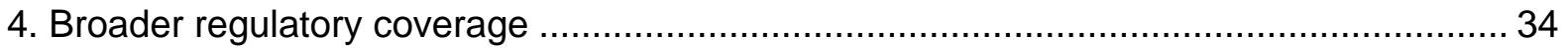

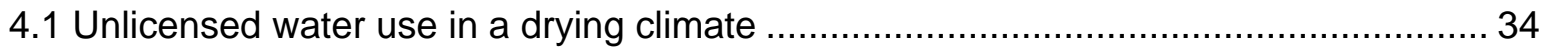

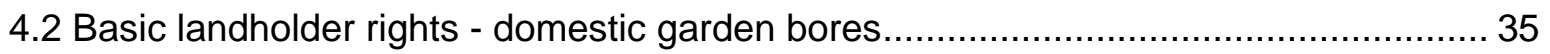

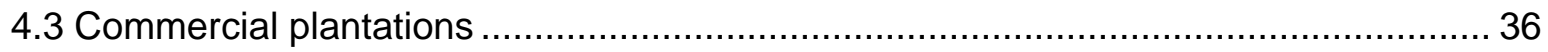

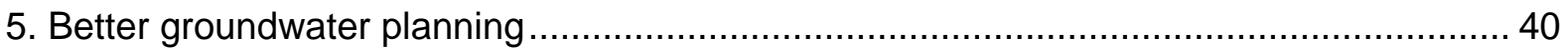

5.1 Statutory water plans and sustainable extraction limits ..................................... 40

5.2 A duty to consider and address risks from climate change ..................................... 42

5.3 Sharing groundwater with the environment in a drying climate .............................. 47

5.4 Sharing groundwater between consumptive uses in a drying climate ....................... 51

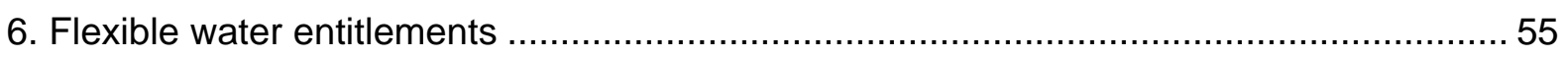

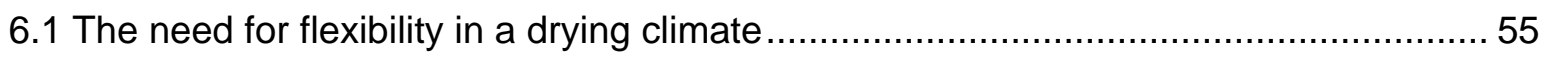

6.2 Problems with the existing entitlements system ................................................. 56

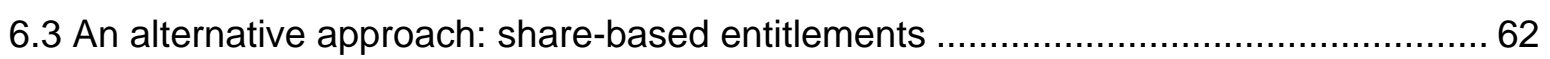

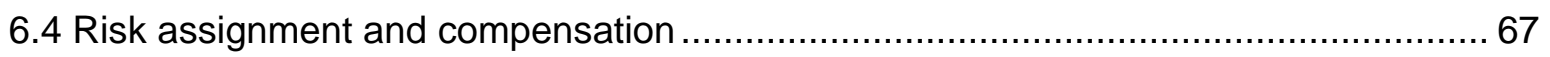

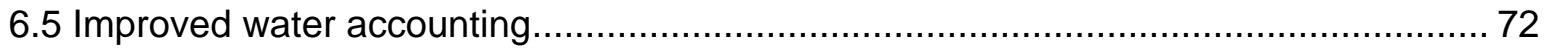

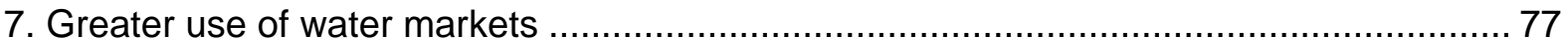

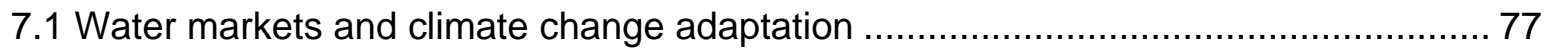

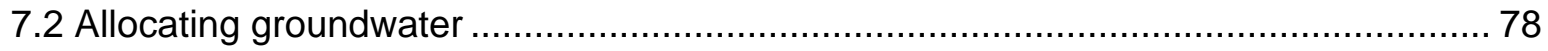

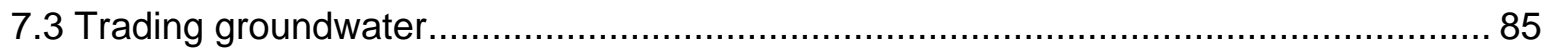

8. Applying the reforms to groundwater resources in the South West .............................. 90

8.1 Defining the consumptive pool in the face of uncertainty ...................................... 90 


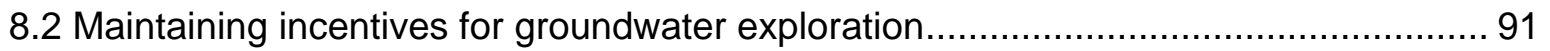

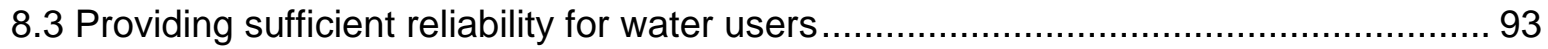

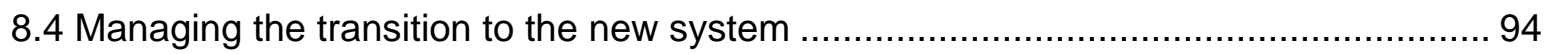

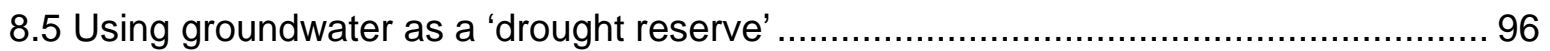

9. Conclusion: groundwater regulation in a drying climate ........................................... 101

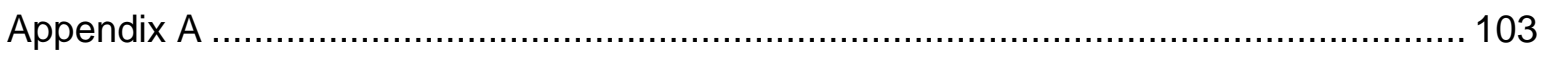

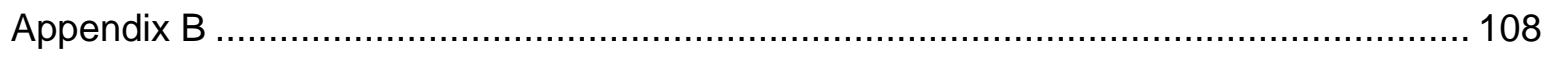

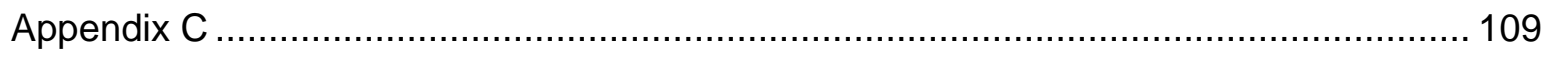

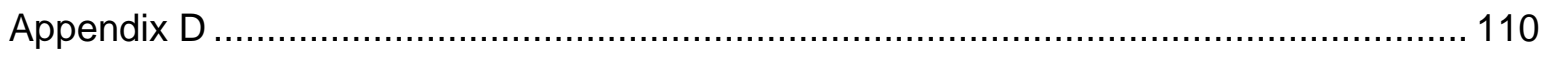

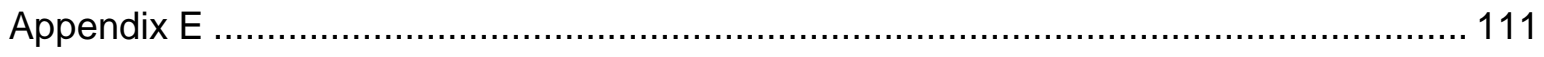

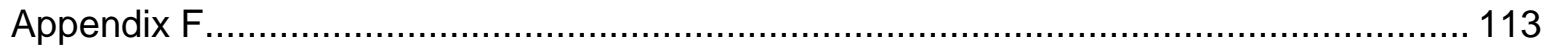

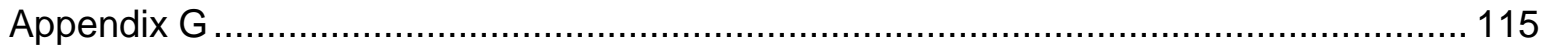

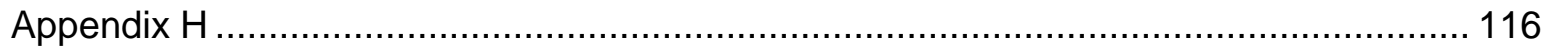

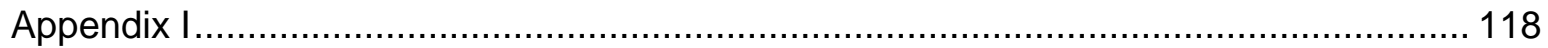

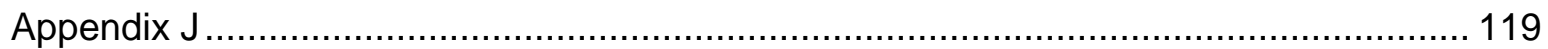

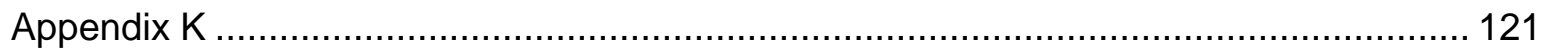

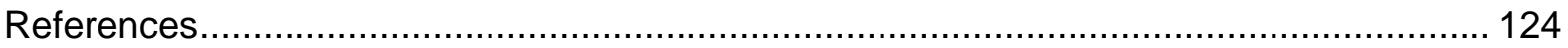

\section{List of figures}

Figure 1: Water resources of the South West............................................................... vii

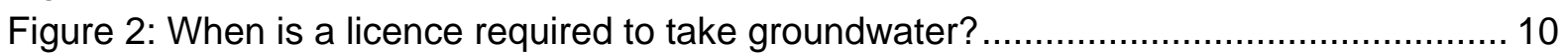

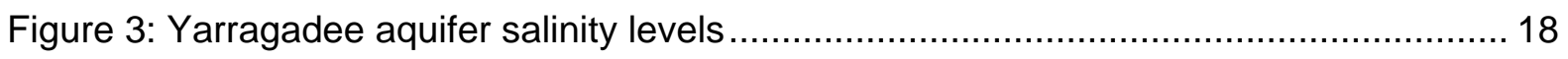

Figure 4: Rainfall trend in Western Australia (1970-2012,mm/10yrs) ................................. 20

Figure 5: Annual rainfall in SWWA (1900-2013)

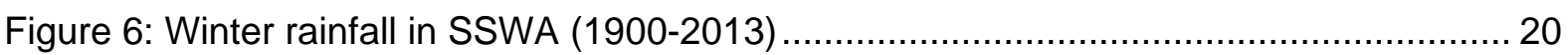

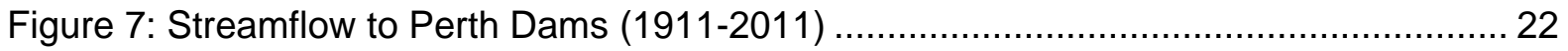

Figure 8: Water sources for the Integrated Water Supply System $(1940-2023)$.................. 23

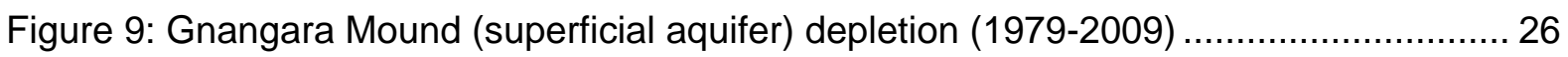

Figure 10: Yarragadee Aquifer (deeper aquifer) pressure levels (1973-2011) .................... 26

Figure 11: Water table trend in the southern Perth Basin (1980-2007) .............................. 27

Figure 12: Projected change in groundwater levels in superficial aquifers of the southern

Perth Basin between 2008 and 2030 (median future climate) ........................................ 30

Figure 13: Unlicensed use crowds out licenced use in a drying climate .............................. 34

Figure 14: CSIRO scenario for decline in Perth rainfall due to climate change (1987) ........ 43

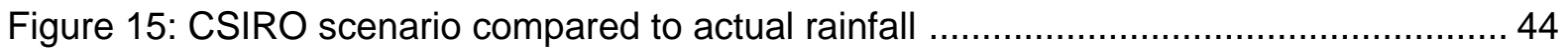

Figure 16: Non-compliant sites on the Gnangara Mound (\% of total sites).......................... 49

Figure 17: Recognising over-allocation: adjustment to allocation limits in a drying climate.. 56

Figure 18: Current entitlements vs National Water Initiative entitlements ............................. 63 


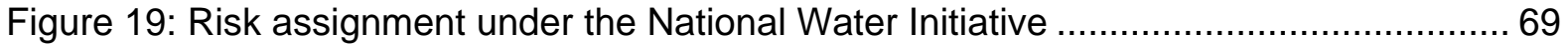

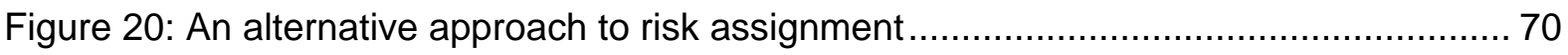

Figure 21: Assessment of Expressions of Interest in the Seabird Subarea, Gingin ............ 82

Figure 22: Trade-off between flexibility and reliability in rules for determining consumptive

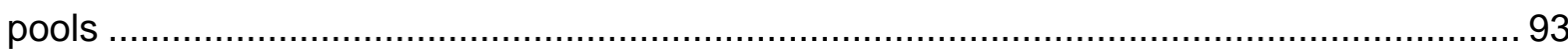

Figure 23: Variable Groundwater Abstraction Rule (2002-3 to 2007-8)............................. 97

Figure 24: Variable Groundwater Abstraction Rule (2008-9 to 2011-12)........................... 98

\section{List of tables}

Table 1: Examples of provisions in South West groundwater allocation plans ...................... 6

Table 2: Common conditions on groundwater licences in the South West .......................... 10

Table 3: Recognised over-allocation in South West groundwater management areas ........ 28

Table 4: Factors affecting watertable decline on the Gnangara Mound ............................... 37

Table 5: North West Corridor Allocation Limits and Licenced Use (2009) ........................... 52

Table 6: Design criteria for public open space in the Northern Corridor .............................. 54

Table 7: Existing regulatory mechanisms to address over-allocation .................................. 56

Table 8 : Water access for power stations in the Collie Basin (2009) ................................ 59

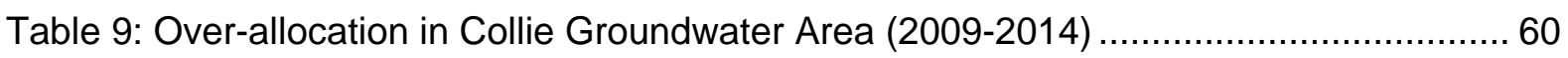

Table 10 : Gnangara groundwater system: licenced entitlements in over-allocated areas... 61

Table 11: Contributions of major water sources to the Perth's water supply ....................... 61

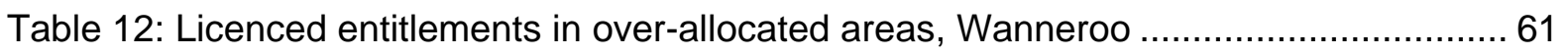

Table 13: Examples of rules for varying the consumptive pool........................................ 63

Table 14: Examples of National Water Initiative-consistent water access entitlements........ 65

Table 15: Water available from the Leederville-Parmelia aquifer in the Mingenew subarea

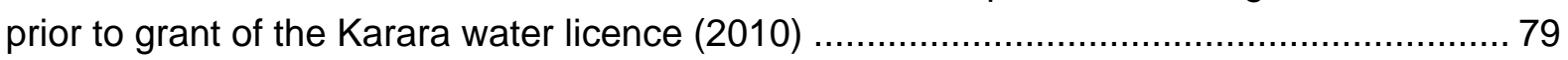

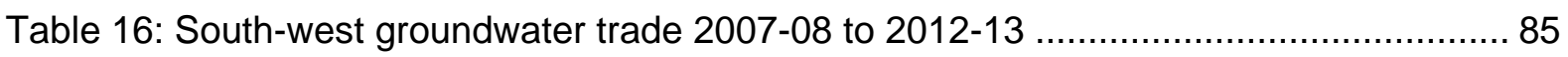

Table 17: Allocation Limits for Gingin Superficial Aquifers (1993-2014) ............................ 91 


\section{Preface}

The South West of Western Australia - which we define broadly to include an area stretching from Geraldton to Albany - has experienced significant challenges from a drying climate over recent decades. The scientific evidence suggests that this drying climate is linked to human-induced climate change, and that further drying is likely as greenhouse gas concentrations in the atmosphere increase. The drying climate is already having very serious consequences for water resources management.

While steps clearly need to be taken to reduce emissions, this Report focuses on adaptation of water resources management, especially in relation to the future of groundwater management and regulation in the South West. This is an important issue, given that groundwater makes up around three quarters of all water used in the South West and supports important environmental assets, including internationally recognised wetlands. The Report analyses existing legislation in the light of academic commentary, government reports and case studies and recommends a series of regulatory reforms designed to adapt groundwater management to a drying climate.

The Report has two key aims: to contribute to the debate on new water resource management legislation proposed for Western Australia, and to contribute to the scholarship on 'climate adaptation law' pertaining to water resource management. In doing so, we are conscious of the value of the South West of Western Australia as a 'field laboratory' of climate change adaptation. ${ }^{1}$

Our research suggests that while Western Australia's groundwater resources have in many respects been well managed, this management could be improved by a more modern regulatory framework that is better suited to keeping groundwater extraction within sustainable limits in a drying climate. We hope this report can make a modest contribution to achieving that outcome.

Michael Bennett and Alex Gardner

Faculty of Law, The University of Western Australia

Researchers with the National Centre for Groundwater Research and Training

30 June 2014

\footnotetext{
${ }^{1}$ Brian Sadler, 'Informed Adaptation to a Changed Climate State: Is South-Western Australia a National Canary?' (2005) <http://www.ioci.org.au/publications/cat_view/16-ioci-stage-2/33-general-papers.html> 1, 8.
} 


\section{Acknowledgements}

We were greatly assisted in the preparation of this Report by a Steering Committee comprising Tad Bagdon, Ed Hauck and subsequently lqbal Samnakay (Department of Water), James Duggie (Department of Environment Regulation), Ruth Harvey and subsequently Vanessa Moscovis and Paul Bendotti (Water Corporation) and Maria Comino (independent water law expert). The Steering Committee provided helpful feedback on our project plan, draft papers and drafts of the Report. Maria Comino also contributed the case study on groundwater trading in NSW featured in Chapter 7 and provided editorial comments. The assistance of Steering Committee members is very much appreciated, as is their recognition of our academic independence. The views in the draft Report are our own, as are any errors.

We would also like to thank the Department of Water for providing Michael Bennett with a desk in its Water Allocation Planning Branch for one day a week during the research phase for this report. This ability to have regular contact with the talented and dedicated staff of the Department was a great help in going beyond black letter law to build an understanding of how groundwater regulation works in practice.

Finally, we thank those participated in the public seminars, meetings and interviews through which we sought feedback on a draft of this report.

Funding for this project was provided by the National Centre for Groundwater Research and Training, an Australian Government initiative supported by the Australian Research Council and the National Water Commission. 


\section{Executive summary}

\section{Groundwater in a drying South West}

The community of South West Western Australia is facing an enormous water resources challenge from climate change, which is raising fundamental questions about the regulatory framework for managing groundwater. Do we need to extend groundwater regulation? Do we need a more rigorous approach to setting allocation limits? Can we continue with fixed, volumetric water rights in a drying climate? What should be the role for water markets in distributing water rights?

The South West of Western Australia is home to around 2 million people, some 90 per cent of Western Australia's population. This community is fortunate to have the benefit of substantial groundwater resources, which meet around three quarters of its water needs, along with the needs of the natural environment including internationally-significant wetlands and groundwater-dependent threatened species.

\section{Figure 1: Water resources of the South West $^{2}$}

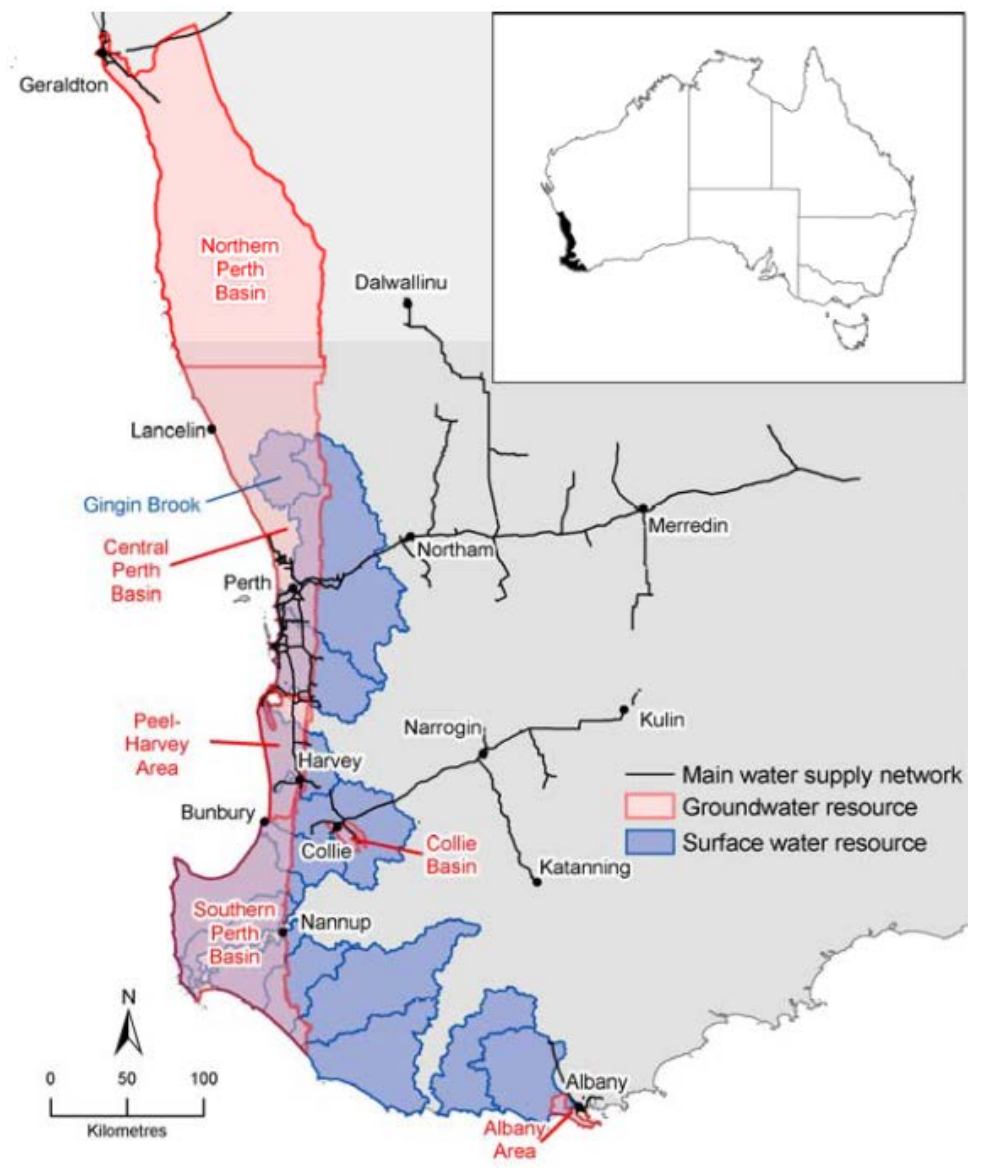

\footnotetext{
${ }^{2}$ CSIRO, 'Water yields and demands in south-west Western Australia: A report to the Australian Government from the CSIRO South-West Western Australia Sustainable Yields Project' (CSIRO, 2009) 5.
} 
The South West has experienced a significant drying trend over recent decades. This decline in winter rainfall (17 per cent since 1970) has been associated with a dramatic decline in streamflow to South West reservoirs (more than 50 per cent). There has also been a substantial impact on groundwater resources - both directly, through reduced recharge to aquifers, and indirectly through increased demand for groundwater as a substitute for increasingly scarce surface water resources.

A number of peer-reviewed scientific papers, and a major research venture carried out by the CSIRO, Bureau of Meteorology and WA Government, have linked the decline in South West rainfall to climate change caused by greenhouse gas emissions. Whatever the cause of past drying, there is a high degree of agreement among climate models that the South West will experience a drying trend in future decades due to human-induced climate change. The impact on groundwater yields will be modest in some areas, but very substantial in others. Yield declines may be greater than one-third by 2030 in the Gnangara, Blackwood and Albany groundwater areas. Impacts on surface-water resources will also have an impact by increasing demand for alternative water sources such as groundwater.

The science suggests that effective action to stabilise greenhouse concentrations could quickly begin reverse this drying trend, but that it would take several centuries to fully reverse. While not detracting from the importance of reducing greenhouse gas emissions, this does underline the importance of considering how the South West can adapt to a dryer future. This report considers how the design of the regulatory framework for groundwater management can help meet this important challenge.

\section{Research questions and directions for reform}

In this report we seek to address the following fundamental questions for groundwater management and regulation:

- How can groundwater use be maintained within sustainable limits in a drying climate, and how can groundwater be used productively and efficiently within these limits?

- What role does the regulatory framework for groundwater management have in achieving these goals?

From an analysis of the existing regulatory framework, an assessment of how it has operated in practice and consideration of approaches in other jurisdictions we have identified four main directions for reform, which we outline below. The first three (broader regulatory coverage, better groundwater planning and flexible water access entitlements) relate to the goal of keeping groundwater use within sustainable limits in a drying climate. The fourth (greater use of water markets) relates to the productive and efficient use of groundwater. These reform directions are consistent with the Intergovernmental Agreement on a National Water Initiative which Western Australia signed in 2006. 


\section{Broader regulatory coverage}

There is value, in a drying climate, in bringing existing, unlicensed uses within the regulatory framework as far as possible. Otherwise there is a risk that these unlicensed uses will expand, unconstrained by an allocation limit, to the detriment of groundwater-dependent ecosystems or licenced water users. There are two unlicensed water uses of groundwater that are potentially problematic: domestic garden bores and commercial plantations.

Domestic garden bores are widely used in the South West. The Department of Water estimated in 2009 that there were 167,000 garden bores in the Perth Metropolitan Area, with total water use in the order of 73 gigalitres (GL) a year. Garden bores are currently exempt from usual licensing requirements (except in the unusual case in which water is not taken solely from the water table aquifer). This needs to be reconsidered in a drying climate particularly in vulnerable areas, such as those that are already over-allocated or are close to wetlands.

\section{Law Reform Recommendation: Domestic Garden Bores}

Consideration should be given to two options:

- to license new and existing domestic garden bores in specified areas, or

- to prohibit the construction of new domestic garden bores in specified areas.

It is clear from studies of the Gnangara Mound that commercial plantations can have a significant impact on groundwater levels in a drying climate. While the Gnangara plantation is an unusual, if not unique, example in the South West of a large commercial plantation being located over a shallow, over-allocated aquifer, there is a strong case for the new water resource management to have the capacity to regulate plantations in specified areas.

South Australia is the first Australian jurisdiction to include commercial plantations within its water management regime. The South Australian reforms only came into effect in October 2013 , so it is difficult to assess their usefulness in practice. Even so, the broad framework provided by these laws - the licensing of commercial plantations in designated areas, with the hydrological impact of those plantations being assessed in accordance with rules in the relevant statutory water allocation plan - appears to offer a workable approach.

\section{Law Reform Recommendation: Commercial plantations}

Western Australia's new water resource management legislation should recognise commercial plantations as a consumptive use of groundwater resources and have the capacity to licence water use by commercial plantations in specified areas identified by the statutory planning process.

\section{Better groundwater planning}

Good water allocation planning is central to maintaining groundwater use within sustainable limits in a drying climate. Important elements of such planning are the use of statutory water allocation plans to provide a consistent, legally secure basis to set and administer allocation 
limits; a transparent process to identify sustainable yields and set allocation limits; and monitoring and reporting on whether allocation limits and plan objectives have been met.

\section{Law Reform Recommendation: Statutory water allocation plans}

The legislation should:

- $\quad$ provide for statutory water allocation plans that bind decision-makers performing functions under the legislation and other government agencies exercising powers under other legislation

- require, as part of the process for preparing each statutory water allocation plan, the publication of a scoping document that details how sustainable yields will be assessed

- require plans to identify the sustainable yield of each groundwater resource, explain how the sustainable yield was calculated and explain any discrepancy between the sustainable yield and the provisions of the plan

- provide that plans must be approved by the Cabinet (Governor in Council) and then tabled in Parliament and subject to disallowance

- specify the monitoring that is to be carried out to assess whether the objectives of plans are being achieved, and requirements for the reporting of that information.

While projections of reduced rainfall due to climate change were taken into account for water supply planning purposes from the late 1980s, they were only directly incorporated in assessments of groundwater allocation limits from 2009, some two decades later. Our analysis of groundwater allocation plans in the South West shows that there is still only one finalised plan that uses climate change projections. The Department of Water has recently done a significant amount of work in developing tools and guidelines to facilitate the use of climate projections in water allocation planning. To ensure that climate change is addressed in the making of water allocation plans we recommend that the new water resource management legislation require the Minister to consider climate change risks in plan preparation and to address those risks in the plan provisions.

\section{Law Reform Recommendation: Duty to consider and address climate change in making statutory water allocation plans}

The legislation should require the Minister to consider climate change risks in the preparation of statutory water allocation plans and to address those risks in the plan provisions.

Water allocation plans can have a role in deciding how groundwater, and groundwater scarcity, should be shared between consumptive uses in a drying climate. Non-statutory water allocation plans commonly reserve groundwater for the purpose of public (drinking) water supply, and the recent strategy to address groundwater shortages in Perth's North West Corridor has also effectively reserved groundwater for the efficient watering of public open space. The power to make reservations of this kind should be retained in the new water resource management legislation to provide the capacity to make sure water is available, on an equitable basis, for water uses that provide a public benefit. 


\section{Law reform recommendation: Reservation of groundwater}

The new water resource management legislation should provide that statutory water allocation plans may reserve water for specified purposes.

\section{Flexible water access entitlements}

Groundwater resources are likely to diminish in a drying climate because of reduced groundwater recharge. This raises the question, in areas that are already fully allocated, of whether the regulatory system is capable of adjusting the volume of water that can be taken under water access entitlements in order to keep total groundwater extraction within sustainable limits, over the medium to longer term and in extreme drought.

Under current law and practice, groundwater entitlements are volumetric - that is, licensees are entitled to extract a specified volume of water each year. During temporary severe water shortages these entitlements may be reduced by ministerial direction, and no compensation is payable. These powers have not been exercised in the past twenty years, even though it is arguable that there have been seasonal circumstances that could have warranted their application. Further, volumetric groundwater entitlements may be reduced permanently on various grounds and no compensation is payable if the reduction is 'fair and reasonable' amongst licensees. In practice, this power has rarely been exercised in over-allocated groundwater areas in the South West. This may be because licensees have an expectation of a fixed annual entitlement and because it would be administratively onerous to amend a large number of licences individually and deal with resulting merits appeals to the State Administrative Tribunal.

The introduction of a more flexible entitlements system, consistent with Western Australia's commitments under the National Water Initiative, would make it easier to manage allocations within sustainable limits in a drying climate. Under this system, water users would hold perpetual share entitlements in a consumptive pool and available water can be accessed in proportion to the share. This consumptive pool could be varied in response to seasonal circumstances, in accordance with rules in the relevant statutory water plan, in order to keep allocations to entitlements within sustainable limits. Variation of the consumptive pool would affect all water users equally, so that the allocation is proportional to the share and no compensation would be payable.

\section{Law Reform Recommendation: A more flexible entitlements system}

The legislation should provide greater flexibility to adjust levels of groundwater extraction in response to seasonal circumstances through non-compensable adjustments made by:

- a new system of water entitlements that provide access to a share of a consumptive pool determined periodically, rather than to a fixed annual volume of water

- pending the introduction of those entitlements, powers to vary more easily the volume of water that may be taken under existing licences.

The legislation should also provide that, where necessary, permanent reductions to groundwater entitlements can be made to adapt to a drying climate. If there is no currently applicable statutory plan, this adaptation is best undertaken by making a statutory plan. If 
there is an existing statutory plan, then a permanent reduction of entitlements can be made by plan amendment, usually at a time prescribed for regular plan review. Such regular review might take place, for example, every ten years, but there should also be ministerial authority to change a plan during the ten year term. If an existing plan provides for consumptive pool determination, then the entitlement reduction can be undertaken by amending the relevant plan rules for determining the consumptive pool. This form of plan amendment may or may not affect all water users equally.

\section{Law Reform Recommendation: A regular plan review of entitlements}

The legislation should provide a capacity for longer term adjustments to climate change impacts by providing for:

- regular plan review, possibly every ten years

- a fair process by which the minister may amend plan provisions to re-set the regime of rules for determination of the consumptive pool and share entitlements.

The legislation should also provide for how the risk of loss from entitlement reductions made by plan amendments is assigned between water users and government. In all Australian jurisdictions that have implemented the National Water Initiative a periodic adjustment to a consumptive pool, made in accordance with a statutory water plan, will apply equally to all entitlement-holders ${ }^{3}$ and is not compensable. However, permanent adjustments to the reliability of water access entitlements through plan amendments, either during the term of a plan or at the end of the plan term, raise more difficult questions of compensation. Water users who invest on the basis of a plan-defined entitlement may legitimately anticipate some security of entitlement during the term of the plan.

One approach put forward in the National Water Initiative, which has been adopted in some Australian jurisdictions, is to provide that reductions in water access associated with plan amendments or new plans may be compensable, depending on the reason for the new approach. If the reduction is needed because of climatic changes no compensation is payable, but compensation may need to be paid if the consumptive pool is reduced because of changes in government policy or improvements in knowledge. This approach is difficult to apply in practice because it is hard to apportion reductions in water entitlements between these different factors.

An alternative approach is to recognise that certainty is needed during the term of a plan, but a regular plan review at the end of the plan term is the opportunity for the community and the government to re-assess the long term sustainability of plan provisions of water for consumptive use and for environmental and other public benefit outcomes. The community and the government may then legitimately anticipate the capacity to re-set the plan regime without the burden of compensation unless the burden of entitlement reductions were to fall disproportionately on particular water users, so that water rights are effectively acquired for a public purpose identified in the new plan.

\footnotetext{
${ }^{3}$ Assuming the entitlement holders have the same level of security.
} 


\section{Law Reform Recommendation: Risk assignment and compensation}

No compensation should be payable for adjustments to consumptive pools, or the rules governing the determination of consumptive pools, by regular end of term plan review and amendment. Permanent regulatory adjustments to consumptive pools and entitlements during the term of the plan would be compensable. Commonwealth structural adjustment assistance, funded by major emitters of greenhouse gases, could be provided to water users affected by climate change.

A flexible water entitlements system will help to keep groundwater allocations within sustainable limits in a drying climate, but this will be to no effect if groundwater use exceeds those limits. We therefore support proposals in the Department of Water's Position Paper, Reforming Water Resource Management ('2013 Position Paper') for increased metering, and suggest some additional reforms to increase compliance with metering requirements and disclosure of data obtained from metering. We also recommend that the legislation should have the capacity to introduce 'net' water accounting that takes into account return flow of water to an aquifer as well as extraction.

\section{Law Reform Recommendation: Improved water accounting}

The legislation should provide for:

- the implementation of increased metering as proposed by the 2013 Position Paper

- a strengthening of enforcement provisions for non-compliance with licence conditions requiring metering and reporting

- reform of the provisions for the water register to mandate on-line publication of licence conditions for metering and of the metering data unless the licensee can show a good reason for non-disclosure

- the capacity to introduce 'net' accounting for groundwater entitlements.

\section{Greater use of water markets}

Water markets promote the productive and efficient use of water. They facilitate the movement of water to its most economically productive use, and by putting a price on water encourage physically efficient water use. Both of these things become increasingly important in a drying climate.

At present market-based mechanisms such as auctions are not used in the initial allocation of groundwater entitlements in the South West. Groundwater is normally allocated for free under a 'first-in, first-served' approach, in which the applicant who is first in time has priority over other applicants. There have also been experiments with 'merit selection', under which expressions of interest for water use are assessed against multiple, often subjective, criteria. The failure to use market-based mechanisms may in part be due to the fact that the current legislation does not provide a clear legal basis to do so. The new legislation should correct this shortcoming. In order to promote productive and efficient use of groundwater, marketbased mechanisms should be considered the default approach for heavily allocated groundwater resources, including where water has been reserved for specified uses. 
Law reform recommendation: Initial allocation of groundwater through market-based mechanisms

The legislation should provide a clear legal basis for the release of unallocated water through a range of mechanisms, including market-based mechanisms such as auctions. Market-based mechanisms should be considered the default approach for heavily allocated groundwater resources.

This raises the question of how the resulting revenue should be used. The State Government's Water Reform Implementation Committee recommended in 2006 that the revenue be directed to water resource management. This would have the advantage of providing much-needed funding for water resource management and building support for the use of market-based mechanisms.

\section{Law reform recommendation: Use of revenue from groundwater allocation}

The revenue from the release of groundwater through auctions and other market-based mechanisms should be directed to water resource management.

Water trading has been possible since 2001 amendments to the Rights in Water and Irrigation Act 1914 (WA) ('RIWI Act'), and a number of water trades have been carried out in South West groundwater areas. However, there are a number of barriers to trade. The State Government proposes to address some of these barriers to trade. One barrier that it does not propose to address is the requirement that the person purchasing the water entitlement must be the owner or occupier of land from which the water is taken, or have an agreement with that person. This makes it more difficult for some prospective water purchasers, such as businesses that wish to acquire a portfolio of water entitlements for leasing or investors acquiring a water entitlement before acquiring land title, to purchase water entitlements.

\section{Law Reform Recommendations: Water trading}

The legislation should be designed to facilitate trade in groundwater entitlements, including through implementation of the reforms outlined in the 2013 Position Paper. The legislation should include the capacity to remove the requirement that a purchaser of an entitlement must be an owner or occupier of the land from which the water will be taken.

\section{Applying these reforms in the South West}

\section{When should the National Water Initiative model be used for groundwater resources?}

The National Water Initiative model, built around the concept of water users holding tradeable shares to a sustainable consumptive pool, is sometimes criticised as an Eastern States invention that works for surface water but isn't suitable for groundwater resources. To some extent this ignores the fact that there are substantial groundwater resources in the Eastern States, and that many of these resources are already subject to the National Water Initiative model. However, it is true that there are issues that need to be addressed in 
applying this model to groundwater resources, and that the model may not be appropriate for all groundwater resources in the South West.

One issue is that the volume of water that is allocated to water entitlements will tend to be unreliable in poorly understood systems. This is because the volume of water that can be taken under an entitlement will change with changes in the consumptive pool. A second issue is that premature introduction of share entitlements and auctions of those entitlements may discourage exploration for new groundwater resources. For these reasons, it may be appropriate for poorly understood systems, and systems in which there is scope for substantial new resources to be identified by exploration, to continue to use the traditional licensing model - albeit with some refinements such as greater flexibility to vary the volume of water taken under those licences.

In other areas, the introduction of the full National Water Initiative model is to be recommended for the reasons discussed above. Experience from other Australian jurisdictions is that the model provides the capacity to find the right balance between flexibility to sustainably manage a groundwater resource and reliability of water access for entitlement holders.

\section{Managing the transition to the new system}

In areas where it is appropriate to introduce the full National Water Initiative reforms, including share based entitlements, there will be issues that have to be addressed in the transition to the new system. There will be particular challenges in areas that are overallocated, as an entitlement to a share of a sustainable consumptive pool may be less than the volume of water available under the old licence. Legislation in other Australian jurisdictions does not provide for compensation for this transition. It could be argued that Western Australia should provide for a different approach because its legislation currently provides for compensation for licence amendments in certain circumstances. However, even if current compensation rights were applied to the conversion of licences to share entitlements, no compensation would be payable where reductions are fair and reasonable between relevant licensees.

\section{Law reform recommendation: Compensation on transition to share entitlements} The new legislation should not provide a right to compensation for losses suffered in the conversion of existing licences to share entitlements, at least where the Minister is satisfied that the conversion is fair and reasonable between relevant licensees.

The new legislation should have the capacity to ease the transition from licenses to share entitlements in over-allocated areas through the use of techniques such as the issuing of temporary supplementary entitlements that phase out over time.

\section{Law reform recommendation: Supplementary entitlements}

The new legislation should provide the capacity to issue supplementary entitlements, which phase out over time, to ease the transition to more sustainable allocation limits in currently over-allocated water resources. 


\section{Use of groundwater as a 'drought reserve'}

One important issue for the South West, along with other areas of the world facing a drying climate, is how groundwater resources should be managed to anticipate future extreme drought. Some groundwater resources - especially deeper, more confined aquifers - may have the capacity to be temporarily overdrawn to meet water needs in periods of drought and replenished through limiting extraction in wetter periods. The experience of groundwater extraction for public water supply in Perth has been one of sustained high groundwater abstraction in a drying climate, rather than strategic use of confined aquifers as a 'drought reserve'. This may in part be due to inadequacies in the current regulatory framework. We suggest a number of options to provide a better regulatory basis for use of groundwater as a 'drought reserve' in a drying climate. The key to each of those options are firm legal safeguards to ensure that a realistic allocation limit is set for a drying climate, and that groundwater extraction is below that limit in relatively wet years to provide room to increase extraction in drought.

\section{Law reform recommendation: Sustainable use of groundwater as a 'drought reserve'} The new legislation should provide the basis for sustainable use of groundwater resources as a 'drought reserve', where appropriate. Regulatory options include:

- The use of 'carryover' or 'borrowing' rules in statutory water allocation plans, leaving it to the entitlement holder to elect when to 'bank' an allocation for later use

- Compulsory 'banking' of a proportion of each entitlement holder's periodic allocation so as to build an individual reserve that is accessible to the entitlement holder in a severe drought as declared by the Minister

- Formal designation of volumes of water in suitable deeper aquifers as a 'drought reserve', accessible through short term licences that are auctioned in severe droughts

- Establishing an independent statutory authority to hold share entitlements as a drought reserve, to be auctioned in extreme droughts.

\section{Concluding points}

The broad conclusion of this report is that new water resource management legislation is needed to meet the challenges of groundwater management in a drying South West. This conclusion is consistent with the reforms outlined in the State Government's 2013 Position Paper, as are many of our recommendations. There are, however, some differences around important issues such as risk assignment and some areas in which our recommendations raise new issues that are not considered in the 2013 Position Paper. A comparison between our proposals and those of the State Government is attached at Appendix A.

Some important general principles emerge from the experience of the South West.

1. One obvious principle is that, in setting limits, governments should not assume past rainfall is a good guide to the future. Climate change projections must be taken into account.

2. However, given that climate science and hydrogeology do not provide a crystal ball, the entitlements system must be flexible enough to allow collective extraction to be 
adjusted under changing conditions. This flexibility should include reductions in consumptive pools to keep extraction within sustainable limits in a drying climate. The flexibility may also include temporary increases in extraction from deeper, more confined aquifers that are managed as 'drought reserves.'

3. Thirdly, there is a need to ensure that the regulatory framework encourages the productive and efficient use of groundwater: this can be achieved through use of market-based mechanisms, but with the ability for governments to reserve water for specified uses where it is in the public interest to do so.

Finally, we note that managed aquifer recharge ('MAR') using waste water or stormwater is becoming increasingly important in the drying climate of the South West, and in other parts of the world seeking to make better use of water resources in a drying climate. While we recognise that MAR raises important issues of regulatory reform, some of which are considered in the 2013 Position Paper, we have not dealt with those issues in this report. These issues are being separately considered, in work led by Alex Gardner, as part of a project being conducted for the CRC for Water Sensitive Cities. 


\section{Groundwater policy and regulation}

This chapter provides context for the analysis in later chapters. It begins by considering, in broad terms, the policy objectives for groundwater management and some of the legal models that can help (or hinder) the achievement of those objectives. It then considers Western Australia's regulatory framework, with a particular focus on how it has been applied to groundwater resources of the South West, and current proposals for reform of that framework.

\subsection{Policy objectives for groundwater management}

Groundwater managers and legislators face two fundamental policy questions: what limits should be placed on the use of groundwater resources, and who should be able to access groundwater within those limits?

In Australia, as in other countries, the answer to the first question has been influenced by attitudes towards groundwater resources. Historically, groundwater resources were seen simply as a factor of production to be harnessed for agricultural and industrial development. ${ }^{4}$ To the extent that limits to groundwater use were considered at all, they were directed towards protecting existing groundwater users and the continued capacity to extract groundwater for development. ${ }^{5}$

The emergence of the concept of sustainable development marked a new stage in the evolution of groundwater policy, along with other areas of natural resource management. The Rio Declaration on Environment and Development ${ }^{6}$ and Agenda $21^{7}$ (1992) emphasised the need to limit resource use, including use of freshwater resources, to levels that could equitably meet the developmental and environmental needs of present and future generations.

This concept was endorsed in Australia, with some variations in terminology, in a number of policy statements and intergovernmental agreements, including the National Strategy on Ecologically Sustainable Development (1992), ${ }^{8}$ the Intergovernmental Agreement on the Environment (1992), ${ }^{9}$ the National Framework for Improved Groundwater Management in Australia (1996) ${ }^{10}$ and, most recently, the Intergovernmental Agreement on a National Water Initiative (2004). ${ }^{11}$ Sustainable

\footnotetext{
${ }^{4}$ Lin Crase, 'An Introduction to Australian Water Policy' in Lin Crase (ed), Water Policy in Australia: The Impact of Change and Uncertainty (Resources for the Future, 2008) .

${ }^{5}$ William M Alley and Stanley A Leake, 'The Journey from Safe Yield to Sustainability' (2004) 42(1) Ground Water 12; Western Australia, Parliamentary Debates, Legislative Assembly, 8 October 1912, 2292 (Minister for Lands) (advocating regulatory controls on artesian bores 'so that there might be no serious loss in the future through a decrease in the flow from bores owing to an excess of bores in a certain area').

${ }^{6}$ Rio Declaration on Environment and Development, United Nations Conference on Environment and Development, reproduced in 31 ILM 874 (1992).

${ }^{7}$ Agenda 21: Programme of Action for Sustainable Development UN GAOR, 46th Sess., Agenda Item 21, UN Doc A/Conf.151/26 (1992).

${ }^{8}$ Australian Government, National Strategy on Ecologically Sustainable Development (1992).

${ }^{9}$ Commonwealth, State, Territory and Local Governments, Intergovernmental Agreement on the Environment (1992).

${ }^{10}$ Australian Government, National Framework for Improved Groundwater Management in Australia (1996).

${ }^{11}$ Council of Australian Governments, 'Intergovernmental Agreement on a National Water Initiative' (2004)
} 
development and related concepts have been incorporated as guiding principles in Australian legislation, including water resource management legislation. ${ }^{12}$

We make three initial observations on the meaning and application of 'sustainable development', 'sustainable yield' and similar terms in a groundwater context. First, what constitutes a sustainable yield depends on the nature of a groundwater resource. For example, different considerations may apply to shallow aquifers recharged by rainfall compared to confined aquifers storing 'fossil water'. It has been suggested that 'mining' of the latter may be considered sustainable in some circumstances, such as where it takes place in a planned way that leaves enough time for alternative water sources to be identified ${ }^{13}$ or provides for recovery of groundwater storage within an acceptable timeframe. ${ }^{14}$

Second, important environmental assets and ecosystem functions must at least be identified; and further, under the relatively strong version of sustainability normally adopted in Australian policy statements (but not always followed through in practice) allocation limits should be consistent with the protection of those assets and functions. ${ }^{15}$

Third, there is a healthy debate about the practical application of concepts like sustainable yield in a groundwater context. For example, the idea that abstraction should be no greater than natural recharge has been variously criticised as a 'water budget myth'16 and praised as a useful guide where it is not possible to develop an accurate numerical model of a groundwater system. ${ }^{17}$ There is also room for debate and different expert judgments on the groundwater flows needed to meet ecological requirements, particularly for groundwater-dependent ecosystems. ${ }^{18}$

Taking these points together, it becomes clear that the identification of allocation limits demands a sophisticated assessment of the impacts that abstraction (and other factors such as land use change) will have on a dynamic groundwater system, and the environmental and social impacts that flow from this for present and future generations. ${ }^{19}$ Overlay the prospect of future climatic

\footnotetext{
${ }^{12}$ On ESD in Australian legislation see Gerry Bates, Environmental Law in Australia (LexisNexis Butterworths, 8th ed, 2013) 227-236; examples of relevant provisions in Australian water resource management legislation include Water Management Act 2000 (NSW) s 3; Water Act 2000 (Qld) s 10; and Natural Resources Management Act 2004 (SA) s 7; Water Act 2007 (Cth) ss 3, 21(4).

${ }^{13}$ Jac Van der Gun and Annukka Lipponen, 'Reconciling Groundwater Storage Depletion Due to Pumping with Sustainability' (2010) 2(11) Sustainability 3418.

${ }^{14}$ GHD et al, 'Guidance for groundwater storage utilisation in water planning' (2012) 7.

${ }^{15}$ Australia's Intergovernmental Agreement on a National Water Initiative, for example, requires that overdrawn water systems should be returned to an 'environmentally sustainable level of take'. This is defined as 'the level of water extraction from a particular system which, if exceeded would compromise key environmental assets, or ecosystem functions and the productive base of the resource': Council of Australian Governments, above n 11 sch B(i),

${ }^{16}$ J D Bredehoeft, 'Safe yield and the water budget myth' (1997) 35(6) Ground Water 929 (arguing that this is a 'water budget myth' because increased abstraction will lead to greater water capture by inducing greater recharge and reducing discharge)

${ }^{17}$ Alley and Leake, above n 5, 3421

${ }^{18}$ National Water Commission, 'Ecological water requirements of groundwater systems: a knowledge and policy review' (2011) ix ('the science to inform the provision for groundwater-dependent ecological values is at an early stage in Australia in comparison with consideration of environmental flows in surface water management').

${ }^{19}$ Yangxiao Zhou, 'A critical review of groundwater budget myth, safe yield and sustainability' (2009) 370(1-4) Journal of Hydrology 207.
} 
shifts to drier and hotter conditions and the task of water managers becomes even more challenging.

Despite these implementation challenges, the concept of sustainable development - with its requirement to consider the developmental and environmental needs of future as well as present generations - offers enduring guidance on management philosophy and issues that should be addressed in setting allocation limits, and in groundwater planning more generally. It is arguably more important than ever under conditions that place additional pressure on groundwater resources, such as the shift to dryer climatic conditions experienced in the South West of Western Australia.

As we have noted, another very important groundwater management issue - and one which comes into sharper focus as water becomes scarcer - is how rights to extract water should be distributed. It is difficult, in this area, to identify any clear and broadly accepted policy objectives. In Australia, a tension has developed between concepts of 'equitable' and 'efficient' water allocations. The concept of 'equitable' allocations is a vague one, but is associated with democratic control over water allocation, exercised through fair decision-making processes. ${ }^{20}$ The concept of 'efficient' water allocation places greater emphasis on the economic utility of water use and is associated with allocation through water markets. Australia's Intergovernmental Agreement on a National Water Initiative places greater emphasis on the latter objective, while maintaining a role for government to set the rules for water allocation through statutory water plans. ${ }^{21}$

\subsection{Legal models for groundwater management}

There are many different legal models that can be used to govern groundwater use. These include:

- a 'rule of capture' model, under which landowners overlying a groundwater resource have unlimited rights to access that resource, ${ }^{22}$

- an 'correlative rights' model, under which landholders may pump as much as they like provided they put it to beneficial use and do not interfere with the ability of other landholders to do the same; ${ }^{23}$

- a 'regulated access' model, under which the state allocates rights to use groundwater through a licence or other instrument. ${ }^{24}$

In Australia the historical common law 'rule of capture' model has been replaced by a statutory 'regulated access' model for most groundwater resources. A particular advantage of this model is that it can set caps on cumulative water use. If the regulatory system covers all significant water users, appropriate caps are set and water use is properly monitored and regulated, such a system provides a good basis to achieve sustainable management of groundwater resources.

\footnotetext{
${ }^{20} \mathrm{G}$ L Syme, B E Nancarrow and J A McCreddin, 'Defining the components of fairness in the allocation of water to environmental and human uses' (1999) 57 Journal of Environmental Management 51.

${ }^{21}$ Council of Australian Governments, above $\mathrm{n} 11$.

${ }^{22}$ Alex Gardner, Richard Bartlett and Janice Gray, Water Resources Law (Lexis Nexis Butterworths, 2009$) 166$.

${ }^{23}$ Josh Patashnik, 'All Groundwater is Local: California's New Groundwater Monitoring Law' (2011) 22 Standford Law and Policy Review 317, 319.

${ }^{24}$ Joseph W Dellapenna, 'Global climate disruption and water law reform in the United States' in Paul Martin et al (eds), Environmental Governance and Sustainability (IUCN Academy of Environmental Law, 2012)
} 
As Dellapenna has noted, the 'regulated access' model also has the advantage, from a climate change adaptation perspective, of providing greater flexibility to adjust water use in a drying climate. ${ }^{25}$ While this is clearly correct, the degree to which water use can be adjusted is affected by the design of the particular regulatory framework (such as the design of the provisions concerning variation of water access rights), not to mention the social and political context in which that framework is used.

\subsection{Western Australia's regullatory framework}

\section{Definition of water resources}

The Rights in Water and Irrigation Act 1914 (WA) ('RIWI Act') is the principal legislation governing groundwater management in Western Australia. Under the RIWI Act, 'water resources' are defined to include:

(a) water courses and wetlands together with their bed and banks;

(b) other surface waters; and

(c) aquifers and underground water ${ }^{26}$.

'Aquifers' is not defined in the Act, but 'underground water' and 'underground water source' is defined to include 'water that percolates from the ground into a well or other works'. ${ }^{27}$

\section{Objectives of water resource management}

Part III of the RIWI Act deals with management of water resources. The objects of the Part are to:

- provide for the management of water resources, and in particular for

- their sustainable use and development to meet the needs of current and future users; and for

- the protection of their ecosystems and the environment in which water resources are situated, including by the regulation of activities detrimental to them;

- promote the orderly, equitable and efficient use of water resources;

- foster consultation with members of local communities; and

- assist the integration of the management of water resources with the management of other natural resources. ${ }^{28}$

The Minister, and other persons having functions under the Act such as delegates of the Minister, must seek to ensure that these objects are achieved. ${ }^{29}$

\section{Water resource planning, monitoring and review}

Under provisions included in the RIWI Act in $2001,{ }^{30}$ the Minister may make regional, sub-regional and local area management plans for the management of water resources. ${ }^{31}$ The RIWI Act

\footnotetext{
${ }^{25}$ Ibid. Dellapenna uses the term 'regulated riparianism' rather than 'regulated access'. We have used the term 'regulated access' because 'riparianism' is less apposite in a groundwater context.

${ }^{26}$ Rights in Water and Irrigation Act 1914 (WA) s2. Note that there is a different definition of 'water resource' in s26GB, which relates to the directions power.

${ }^{27}$ Ibid.

${ }^{28}$ Ibid s 4(1).

${ }^{29}$ Ibid s 4(3).
} 
provides that these plans are one of a number of relevant considerations to be taken into account in licensing decisions. ${ }^{32}$

We won't describe the RIWI Act planning provisions here, because they aren't used in practice. Why is that? It may, in part, be due to the demands on departmental resources that would be associated with preparing three sets of management plans (regional, sub-regional and local). ${ }^{33}$ Another reason may be the statutory requirement for the Minister to seek advice from the Water Resources Council on a proposed plan. ${ }^{34}$ Despite the mandatory language of the Water (Agencies) Powers Act 1984 (WA) ${ }^{35}$ this body has never been established.

The Department of Water has prepared a number of non-statutory plans, known as water allocation plans, which perform similar functions to the water resource management plans contemplated by the RIWI Act. These plans have been prepared for most areas with managed groundwater resources ${ }^{36}$ in the South West (see Appendix C). This is consistent with the Department's practice of generally developing allocation plans for resources where 30 per cent or more of the allocation limit is committed. ${ }^{37}$ There are exemptions, however. Perth's Jandakot Mound and Albany's groundwater resources are two important and heavily allocated groundwater areas that do not have allocation plans. ${ }^{38}$

The non-statutory water allocation plans are developed with the benefit of public consultation and commonly set objectives, management measures and performance indicators. Some examples are provided in Table 1.

\footnotetext{
${ }^{30}$ Rights in Water and Irrigation Amendment Act 2000 (WA) (commenced 10 Jan 2001: see s2 and Western Australia, Government Gazette, 10 Jan 2001 163).

${ }^{31}$ Rights in Water and Irrigation Act 1914 (WA), ss 26GW, 26GX, 26GY.

${ }^{32}$ Rights in Water and Irrigation Act 1914 (WA) sch 1, cl 7.

${ }^{33}$ As we see below, non-statutory water allocation plans have generally been prepared in a 'single layer' rather than in a hierarchy of regional, sub-regional and local plans. Some non-statutory regional plans, with a broader focus than that contemplated by the RIWI Act, have also been developed: e.g. Department of Water, 'Water planning for the South West Region 2010-2030' (Government of Western Australia, 2010).

${ }^{34}$ Rights in Water and Irrigation Act 1914 (WA), inserted in its current form by s26, Water Resources Legislation Amendment Act 2007 (WA).

${ }^{35}$ Water (Agencies) Powers Act 1984 (WA) s 16 ('The Minister is to appoint 6, 7 or 8 persons to be the members of a body called the Water Resources Council'). This provision was inserted by s107 of the Water Resources Legislation Amendment Act 2007 (WA).

${ }^{36}$ As discussed in the following section, some non-artesian groundwater is not regulated under the RIWI Act.

${ }^{37}$ Department of Water, 'Water Allocation Planning in Western Australia: A Guide to Our Process' (2011) 2.

${ }^{38}$ In the case of the Jandakot Mound, part of the explanation may lie in the fact that groundwater extraction in the Jandakot area was subject to environmental impact assessment under Part IV of the Environmental Protection Act 1986 (WA) and is governed by Ministerial Conditions imposed following that assessment.
} 
Table 1: Examples of provisions in South West groundwater allocation plans ${ }^{39}$

\begin{tabular}{|c|c|c|}
\hline Objective & Management measure & Performance indicator \\
\hline $\begin{array}{l}\text { Maintain adequate } \\
\text { groundwater levels to } \\
\text { sustain the renewable } \\
\text { capacity of the water } \\
\text { resource }\end{array}$ & $\begin{array}{l}\text { Allocation limits for total consumptive use } \\
\text { set at less than estimated recharge }\end{array}$ & Change in groundwater levels \\
\hline $\begin{array}{l}\text { Prevent inland movement } \\
\text { of seawater interface }\end{array}$ & $\begin{array}{l}\text { Allocation limits for total consumptive use } \\
\text { set at a level that will maintain groundwater } \\
\text { flow to the sea. Abstraction near the coast } \\
\text { to be limited. If seawater interface is found } \\
\text { to be intermixing with an aquifer the } \\
\text { Department may restrict coastal pumping } \\
\text { or require draw points to be moved. }\end{array}$ & $\begin{array}{l}\text { Movement of seawater } \\
\text { interface }\end{array}$ \\
\hline $\begin{array}{l}\text { Protect groundwater- } \\
\text { dependent ecosystems }\end{array}$ & $\begin{array}{l}\text { Cumulative allocation limits for licensed } \\
\text { abstraction, plus case-by-case assessment } \\
\text { of licence applications for impacts on } \\
\text { groundwater-dependent ecosystems }\end{array}$ & $\begin{array}{l}\text { Minimum groundwater levels } \\
\text { for environmentally significant } \\
\text { sites }\end{array}$ \\
\hline
\end{tabular}

As their name suggests, water allocation plans identify cumulative allocation limits for groundwater abstraction. The Department of Water's publication 'Water Allocation Planning in Western Australia: A Guide to our Process' ('Water Allocation Planning Guide') states that before an allocation limit is set the Department will set environmental water requirements and assess the 'resource yield' - effectively the sustainable yield - needed to meet those requirements. ${ }^{40}$ In South West groundwater management areas this assessment is typically done using computer-based, numerical simulations. ${ }^{41}$ However, there is no requirement that non-statutory plans or associated methods reports contain this sustainable yield figure. Nor is there any requirement that the final allocation limit be consistent with the sustainable yield. ${ }^{42}$

As illustrated in the extract from the Arrowsmith Groundwater Allocation Plan at Appendix B, in practice a water allocation plan will identify:

- an allocation limit for total consumptive use for the relevant sub-area/aquifer;

\footnotetext{
${ }^{39}$ The examples in the first row are drawn from Department of Water, 'Arrowsmith Groundwater Allocation Plan' (2010), 8 and Department of Water, 'Review of the Jurien and Arrowsmith Groundwater Limits: Supporting Information for the Jurien and Arrowsmith Groundwater Allocation Plans' (2009), Appendix A. The examples in the second row are drawn from Department of Water, 'South West Groundwater Areas Allocation Plan' (2009),15-16, 32, 40, 42, 58. The final example is drawn from Department of Water, 'Gnangara Groundwater Areas Allocation Plan' (Department of Water, 2009) 37, 65.

${ }^{40}$ Department of Water, above $\mathrm{n} 37,24$.

${ }^{41}$ A number of different groundwater models are used by the Department of Water in allocation planning. The principal models in our study area are the Perth Regional Aquifer Modelling System (PRAMS), which covers an area of about $10,000 \mathrm{~km}^{2}$ between Mandurah in the south and Moora in the north; the Peel-Harvey Regional Aquifer Modelling System (PHRAMS) which covers an area of about $4095 \mathrm{~km}^{2}$ between Peel Inlet and Bunbury; and the South West Aquifer Modelling System (SWAMS) which covers an area of about $8500 \mathrm{~km}^{2}$ and the three main aquifers (Superficial, Leederville and Yarragadee) in the Southern Perth Basin: CSIRO, above n 2, 48.

${ }^{42}$ Indeed, the Water Allocation Planning Guide makes clear that the 'resource yield' is a 'baseline' which can be adjusted, and that current and predicted future consumptive use is 'a major deciding factor' in how allocation limits are set: Department of Water, above n 37, 19, 24.
} 
- an estimate of unlicensed use;

- any water reserved as a source of future public water supply; and

- the remaining component available for licence allocation.

In practice, revised allocation limits (and other components such as water reservations) may be published in a new allocation plan, through less formal documents or even applied in the licensing process prior to publication in any form.

The Water Allocation Planning Guide requires non-statutory plans to set out a monitoring program. ${ }^{43}$ Monitoring relates to resource management objectives and associated performance indicators specified in the plan, rather than the more general RIWI Act objectives. ${ }^{44}$

In relation to reporting, the Water Allocation Planning Guide provides that a resource review and an evaluation statement should be published regularly, generally on an annual basis. ${ }^{45}$ The resource review is to include measurement and monitoring information, such as trends in water levels. ${ }^{46}$ The evaluation statement is to provide a brief summary of, among other things, performance against plan objectives and changes in allocation status (e.g. whether any areas have become over-allocated).$^{47}$ In practice, evaluation statements for groundwater management areas in the South West have not been published annually (see Appendix C) and no resource reviews have been published.

\section{Regulation of water access}

\section{When a licence is needed for groundwater abstraction}

Subject to some exceptions, a person must be licensed to take water from an underground water source that is either:

- artesian underground water; ${ }^{48}$ or

- non-artesian groundwater in a proclaimed area or an area prescribed by regulations. ${ }^{49}$

While no areas have been prescribed by regulation, groundwater management areas have been proclaimed throughout the South West, covering most of the groundwater resources of the area. Approximately 90 per cent of Western Australia's groundwater resources are within proclaimed areas. ${ }^{50}$ To the extent that there are groundwater resources outside proclaimed areas, these tend

\footnotetext{
${ }^{43}$ Ibid 33. This differs from the RIWI Act requirement, which is that regional, sub-regional and local area management plans must 'specify the monitoring and reporting (which is to occur at least once in every 7 years) to be carried out by the Minister to ensure, as far as practicable, that the objects of this Part are achieved in the implementation of the plan':

Rights in Water and Irrigation Act 1914 (WA) ss 26GW(3), 26GX(3), 26GY(3).

44 Ibid.

45 Ibid 4, 31.

${ }^{46}$ Ibid 30.

47 Ibid.

${ }^{48}$ Rights in Water and Irrigation Act 1914 (WA) s 5C(2)(c). 'Artesian underground water' is not defined, but 'artesian well' is defined 'as a well, including all associated works, from which water flows, or has flowed, naturally to the surface': $\mathbf{s} 3$.

${ }^{49}$ Ibid s 5C.

${ }^{50}$ National Water Commission, National Water Planning Report Card (2011), 353. Maps of the proclaimed areas are available on the Department of Water website:

<http://www.water.wa.gov.au/Tools/Maps+and+atlases/Proclaimed+area+maps/default.aspx\#1>.
} 
to be isolated aquifers in fractured rocks. ${ }^{51}$ The use of these resources doesn't raise the same issues of impacts on neighbours or the environment as groundwater resources in proclaimed areas. $^{52}$

A person does not need a licence to take non-artesian groundwater where an order to this effect has been approved by the Governor and published in the Government Gazette. ${ }^{53}$ Using this mechanism, exemptions from licensing apply to taking water for:

- firefighting; ${ }^{54}$

- watering cattle or other stock, other than those being raised under intensive conditions; ${ }^{55}$

- watering an area of lawn or garden that does not exceed 0.2 hectares; ${ }^{56}$

- other ordinary domestic uses; ${ }^{57}$

- short term dewatering; ${ }^{58}$

- taking of water for monitoring purposes. ${ }^{59}$

Most exemptions only apply where the water is taken from the 'water table aquifer'. ${ }^{60}$ This explains why, for example, a small proportion of domestic bores in the south west are licenced: it is because they take water from an aquifer other than the 'water table aquifer'. ${ }^{61}$

The RIWI Act provides a second mechanism for exemptions: the Minister may make local by-laws that authorise persons to take groundwater (including artesian water) for particular purposes or under particular circumstances. ${ }^{62}$ As at the date of writing, no such by-laws were in effect. ${ }^{63}$

The Act also provides that a person does not need to obtain a licence to take water where water is taken 'under and in accordance with ... a right conferred by another written law'. ${ }^{64}$ This exception does not appear to have any substantial effect in practice. For example, a mining company wishing

\footnotetext{
${ }^{51}$ Pers comm, Ben Drew, Department of Water, 21 November 2013. This is not always the case, however. For example, the Water Corporation's Nannup bore, which is licenced to draw 1.09GL from the Yarragadee South aquifer, is in an unproclaimed area. The Water Corporation needs a licence, even though the area is unproclaimed, because the Yarragadee is an artesian aquifer.

52 Ibid.

${ }^{53}$ Rights in Water and Irrigation Act 1914 (WA) s 26C.

${ }^{54}$ Western Australia, Government Gazette, No 132, 8 July 2011, 2902.

55 Ibid.

56 Ibid.

57 Ibid.

${ }^{58}$ Western Australia, Government Gazette, No 29, 4 March 2011, 702. There are a number of criteria that need to be met for the exception to apply, including that the dewatering the water is taken at a pump rate not exceeding ten litres per second over a period of less than 30 consecutive days.

${ }^{59}$ Western Australia, Government Gazette, No 43, 16 March 2012, 1274.

${ }^{60}$ Western Australia, Government Gazette, No 132, 8 July 2011, 2902; Western Australia, Government Gazette, No 29, 4 March 2011, 702. The only exemption that is not qualified in this way is the monitoring exemption.

${ }^{61}$ The term 'water table aquifer' is not defined in legislation or in the exemption instrument. A departmental policy defines it as 'an aquifer which generally receives direct recharge from rainfall. Its upper surface is the water table and the aquifer is not confined or is under pressure': Department of Water, 'Strategic policy 2.03 - Managing unlicensed groundwater use' (2009) 18.

${ }^{62}$ Rights in Water and Irrigation Act 1914 (WA) s 26L(3)(c), s 5C(1)(c)(ii).

${ }^{63}$ State Law Publisher, Rights in Water and Irrigation Act 1914: Subsidiary legislation as made under this Act <http://www.slp.wa.gov.au/legislation/statutes.nsf/main_mrtitle_844_subsidiary.html>.

${ }^{64}$ Rights in Water and Irrigation Act 1914 (WA) s 5C(1)(c)(iii).
} 
to 'dewater' to give it access to a mineral will need to obtain a licence under the RIWI Act, notwithstanding the fact that mining and associated dewatering has been approved under the Mining Act 1978 (WA) ${ }^{65}$ or a State Agreement Act. ${ }^{66}$

There are native title rights to water under the common law and the Native Title Act 1993 (Cth). ${ }^{67}$ The status of native title is currently undetermined in the South West.

Importantly, the RIWI Act regulates the 'taking' of water from groundwater sources. This term probably does not extend, and in practice has not been treated as extending, to the use of groundwater by plantations. It is, however, treated as extending to the use of a dam that intercepts a water table.

The penalty for taking water without a licence, or for breaching a condition of a licence, is a fine of up to $\$ 10,000$ ( $\$ 50,000$ for corporations) plus a daily penalty of up to $\$ 1,000$ ( $\$ 5,000$ for corporations) ${ }^{68}$

\footnotetext{
${ }^{65}$ While the statutory provisions are not entirely clear, the better view is that a mining tenement cannot preclude the need for a licence under the Rights and Water and Irrigation Act 1914: see Alex Gardner, 'Mining Access to Water Resources Traditions and Developing Principles' (Paper presented at the AMPLA, Thirty-Seventh National Conference, Adelaide, South Australia, 2013) 6ff; M Crommelin and R Hunder, 'Water and Mining - Controls in Conflict' (1989) Australian Mining and Petroleum Law Association Yearbook 201; Katie Winterbourne, 'Obtaining Access to Water for Mining Purposes in Western Australia' (1997) 16 Australian Mining and Petroleum Law Journal 166. In any case this issue does not arise in practice because the Department of Mines and Petroleum imposes a standard condition on mining tenements stating that ' $[\mathrm{t}]$ he abstraction of groundwater is prohibited unless a current licence to construct/alter a well and a licence to take groundwater has been issued by the [Department of Water]': see Department of Water and Department of Mines and Petroleum, 'Administrative Agreement Between the Department of Mines and Petroleum and the Department of Water for Mineral Exploration and Mining Operations in Water Resources Areas in Western Australia' (2012), 16.

${ }^{66}$ For example, dewatering activities form part of proposals approved by the Minister for State Development under the Collie Coal (Western Collieries) Agreement Act 1979 (WA) and the Collie Coal (Griffin) Agreement Act 1979 (WA), but the companies concerned must obtain licenses under s5C of the Rights in Water and Irrigation Act 1914, and have done so: per comm, Andrew Cresswell, Department of Water, 25 November 2013; Collie Coal (Griffin) Agreement Act 1979 (WA) sch 1, cl 40 ('The Company shall make all necessary applications from time to time to the proper authorities and the Commonwealth and the State for the grant to it of any licences or consents required under Commonwealth or State law to permit it to enter this Agreement and perform its obligations hereunder'); Collie Coal (Western Collieries) Agreement Act 1979 (WA) sch 1, c; 41 (to the same effect). Of course, the fact that an approval has been given under a State Agreement Act makes it very unlikely that a licence would be refused.

${ }^{67}$ Gardner, Bartlett and Gray, above n 22, Chapter 13.

${ }^{68}$ Rights in Water and Irrigation Act 1914 (WA) s 5C(1); Sentencing Act 1995 (WA) ss 9, s 40(5).
} 
Figure 2: When is a licence required to take groundwater?

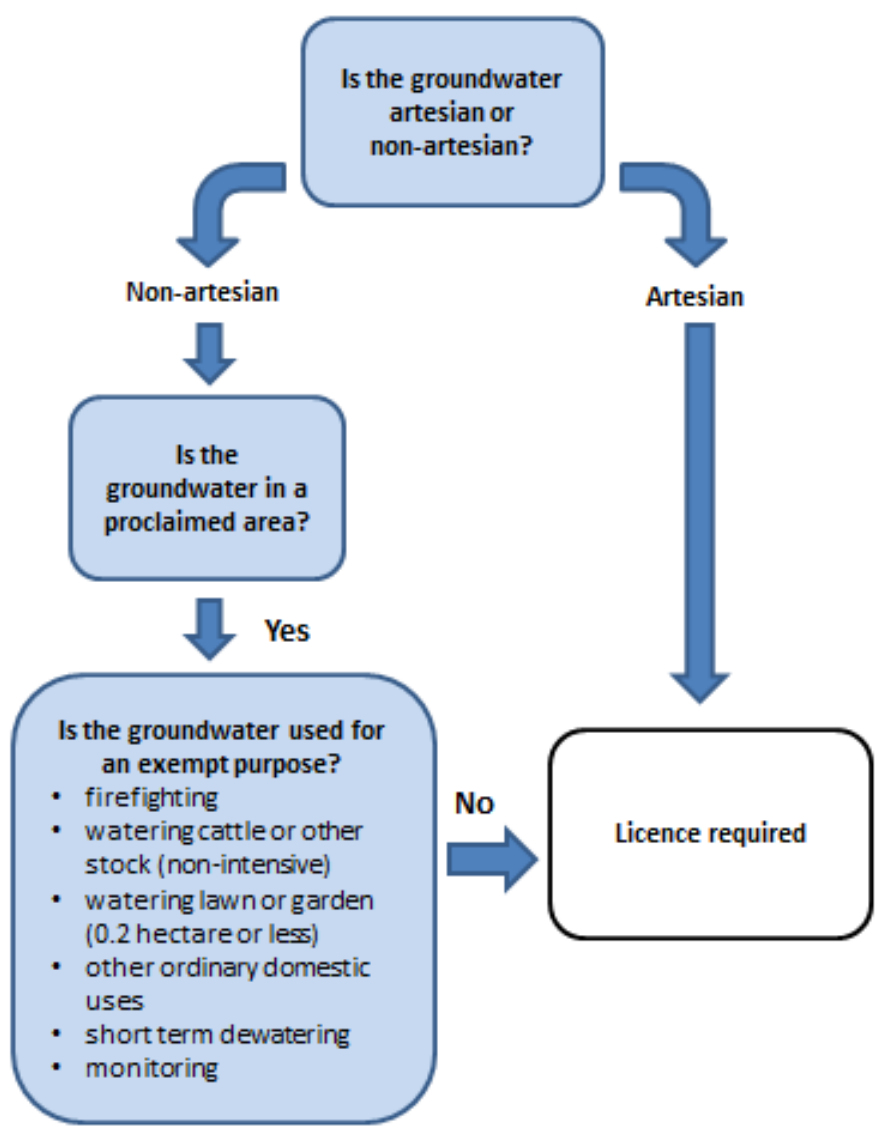

\section{Nature of water access rights}

A licence may authorise the taking of water for a fixed period or an indefinite duration. ${ }^{69}$ In practice, licences specify an annual volumetric water entitlement and are usually issued for up to 10 years. ${ }^{70}$ During the term of the licence, the licence-holder may take water as long as this is done in a manner consistent with any terms, conditions or restrictions on the licence. ${ }^{71}$ Table 2 gives examples of such conditions.

Table 2: Common conditions on groundwater licences in the South West ${ }^{72}$

\begin{tabular}{|l}
\hline Issue \\
Metering \\
$\begin{array}{l}\text { 'The licensee must install an approved meter to each water draw-point through } \\
\text { which water is taken under this licence' }\end{array}$ \\
\hline 'The licensee must take and record the reading from each meter required under \\
this licence at the beginning and another at the end of the water year defined on \\
this licence.'
\end{tabular}

\footnotetext{
${ }^{69}$ Rights in Water and Irrigation Act 1914 (WA) sch 1, cl 12.

${ }^{70}$ Department of Water, 'Securing Western Australia's Water Future: Position paper - Reforming Water Resource Management' (2013), 12 (as to term of licence).

${ }^{71}$ Rights in Water and Irrigation Act 1914 (WA) s 5C.

72 Pers comm Caroline Mellish, Department of Water, 28 November 2013, 13 January 2014.
} 


\begin{tabular}{|ll|}
\hline Reporting & $\begin{array}{l}\text { 'Every [specified period] the licensee shall provide to the Department of Water a } \\
\text { Groundwater Monitoring Summary for the preceding water year. The first report is } \\
\text { due [specified date].' }\end{array}$ \\
\hline Salinity & 'No water may be taken from any well where the salinity level is greater than \\
[amount] millisiemens per meter measured at 25 degrees Celsius.'
\end{tabular}

There are a number of ways in which a licence-holder may be prevented from taking the full amount of the annual volumetric water entitlement specified in a licence:

- Conditions on a RIWI Act licence may restrict the taking of water. For example, as noted in Table 2 above a condition on a licence may provide that no water may be taken from a well where salinity exceeds a specified concentration.

- Other laws may restrict the taking of water. For example:

- abstraction proposals with significant environmental impacts may be assessed under the Environmental Protection Act 1986 (WA) and subject to conditions that restrict abstraction - for example by requiring pumping to be modified if wetland water levels fall below a specified level; ${ }^{73}$

- abstraction proposals that may affect Ramsar Wetlands or nationally-threatened species or ecological communities may be assessed under Environment Protection and Biodiversity Conservation Act 1999 (Cth) and subject to conditions that restrict abstraction; ${ }^{74}$

- the Contaminated Sites Act 2003 (WA) may prevent abstraction of groundwater on a site that has been classified as contaminated; ${ }^{75}$

- The Minister (or departmental delegate) may, by notice in writing, give a direction to a person restricting the amount of water the person may take from a water resource. Such a direction may be issued where the Minister has determined that the quantity of water in a water resource is, or is likely to be, insufficient to meet demand, including any demand

\footnotetext{
${ }^{73}$ For an example of the latter, see the conditions that originally applied to the Water Authority on its proposal to abstract water from the Jandakot Mound: Minister for the Environment, Statement that a Proposal May be Implemented (Pursuant to the Provisions of the Environmental Protection Act 1986) (Ministerial Statement 253, 29 April 1992), Condition 1 and Summary of Environmental Management Commitments.

${ }^{74}$ For an example of an abstraction proposal in the South West that was assessed under the Environment Protection and Biodiversity Conservation Act 1999 (Cth) see: Australian Government, Approval: Bemax Resources Titanium Mineral Mining Project, Wonnerup, WA (EPBC 2010/5403), condition 13 (proponent required to prepare and comply with a water management plan).

${ }^{75}$ For example, some residential land in Perth has been classified as 'contaminated - restricted use' because of concentrations in the heavy metals and acidity concentrations in the groundwater beneath that land. Groundwater abstraction is not permitted at those sites. See Department of Environment Regulation, Contaminated Sites Database, $<$ https://secure.dec.wa.gov.au/idelve/css/> (search suburb of Gwelup).
} 
made by the needs of the environment; or where the Minister has made, and published in the Gazette, an order declaring that a water shortage exists in the area in which the water resource is situated. ${ }^{76}$

- The licence may be amended to reduce the annual volume of water available under the entitlement. Under the RIWI Act the Minister (or departmental delegate) may vary any term, condition or restriction in a licence on a broad range of grounds, including to protect the water resource or the associated environment from unacceptable damage, or to prevent a serious inconsistency arising with a water allocation plan approved under the Act. ${ }^{77}$

It is only under the last of these scenarios that compensation may be payable. Under complex compensation provisions inserted in the RIWI Act in 2001, a person may have a right to compensation where they suffer damage as a result of a licence amendment, suspension or cancellation (but not as a result of a refusal to renew a licence). It is clear that, under these provisions, compensation is not available where a licence is amended to recoup unused water entitlements ${ }^{78}$ and that compensation may be available in most other cases, such as where a volumetric water entitlement is reduced to protect the water resource or the associated environment, or for consistency with an approved water resource management plan. ${ }^{79}$ However, the right to compensation is so heavily qualified with exceptions that it has very little practical application. There are two important exemptions:

- In all cases, compensation is only available if the licence holder's use of water is consistent with the objects of the Act. This arguably means that no compensation is payable where entitlements are reduced to return water use to sustainable levels, given that one of the objects of the Act is sustainable water use. ${ }^{80}$

- In most cases, compensation will not be available unless 'the effect of the exercise of the power on the person is permanent' and 'the Minister is of the opinion that the effect of the exercise of the power on the person is not fair and reasonable having regard to the exercise of the power in respect of other licence holders in the surrounding area'. ${ }^{81}$

\section{Allocation of water access rights}

Water licences are not fully 'unbundled' from land in Western Australia. In order to hold a licence, a person must ordinarily be an owner or occupier of the land to which the licence relates, or have the

\footnotetext{
${ }^{76}$ Rights in Water and Irrigation Act 1914 (WA) S 26GD.

${ }^{77}$ Ibid sch 1, cl 34. In practice this power has not exercised on these broad grounds; its use has been confined to cases in which licence holders have consistently failed to use their full water entitlement.

${ }^{78}$ Rights in Water and Irrigation Act 1914 (WA) cl 39(1) does not refer to cl 24(2)(d), which empowers the Minister (or delegate) to amend a licence where the quantity of water that may be taken under the licence has consistently not been taken.

${ }^{79}$ Ibid cl 39(1), 24(2), 25(2).

${ }^{80} \mathrm{Ibid} \mathrm{s} 4$. This would be consistent with the statement in the Second Reading speech for the Amendment Bill that no compensation is payable for 'changes that are necessary to reduce excessive use to sustainable levels': Western Australia, Parliamentary Debates, Legislative Assembly, 1 July 1999, 9338 (Dr Kim Hames, Minister for Water Resources).

${ }^{81}$ Ibid sch 1, cl 39(5)(b). This exception does not apply where the amendment to the licence is made on public interest grounds.
} 
agreement of the owner and occupier to be on the land and do the things that may be done under the licence. ${ }^{82}$

A person that meets these eligibility requirements may apply for a licence to take groundwater.

There is no application fee. The Department, in considering an application for a licence, must have regard to all matters it considers relevant, including whether the proposed taking and use of water:

- are in the public interest

- are ecologically sustainable

- are environmentally acceptable

- may prejudice other current and future needs for water

- would have a detrimental effect on another person

- could be provided for by another source

- are in keeping with

- local practice

- a relevant local by-law

- a water allocation plan approved under the Act

- relevant previous licensing decisions

- are consistent with

- land use planning instruments

- the requirements and policies of other government agencies

- any intergovernmental agreement or arrangement. ${ }^{83}$

Two points should be made about how these considerations are applied in practice.

First, while allocation limits are an important consideration, it can by no means be assumed that an application will be granted in areas where water is available. A proposal may be rejected because of its impacts on the water resource, other users or the environment, even if the volume of water to be taken is within the relevant allocation limit for consumptive use. For significant applications, the Department may require the applicant to provide a hydrogeological report considering these issues before a decision is made on the application. ${ }^{84}$

Secondly, the reference to 'current and future needs for water' is used to support a policy of 'reserving' water for future public supply. Non-statutory plans commonly identify a volume of water that is reserved for this purpose: see Appendix B for an example of this. A licence will ordinarily

\footnotetext{
${ }^{82}$ Rights in Water and Irrigation Act 1914 (WA) sch 1, cl 3. Public authorities with powers under a written law in relation to water on or under any land, but whose powers are exercisable in accordance with a licence, are also eligible to hold a licence: Ibid. An exception is also made for persons prescribed in local by-laws, but no such by-laws have been made. ${ }^{83}$ Rights in Water and Irrigation Act 1914 (WA) sch 1, cl 7(2).

${ }^{84}$ Ibid sch 1, cl 5(2) (power to require applicant to provide information); Department of Water, 'Operational Policy 5.12 Hydrogeological Reporting Associated with a Groundwater Well Licence' (2009), 8 (the Department will determine whether a hydrogeological assessment is required having regard to the volume and pumping regime requested, level of use in groundwater management area, potential impacts upon other users, potential impacts upon groundwaterdependent ecosystems and existing salinity of the groundwater resource).
} 
be refused if it would involve accessing this reserved water, but if this water is not immediately required for public water supply temporary licences may be issued for other purposes. ${ }^{85}$

Subject to satisfying the considerations listed above, a licence will be granted on a 'first in - first served' basis. There is a provision in the RIWI Act that may, with supporting regulations, provide the basis for the sale of licences, ${ }^{86}$ but this provision has never been used. Apart from the costs to the applicant of preparing its licence application and abstracting the water, groundwater (and surface water) is free.

\section{Trade in water access rights}

Under amendments to the Act that came into effect in 2001 there are currently three ways to trade water.

- First, a licence may be permanently transferred to another person. ${ }^{87}$ This mechanism is intended for use where water is to be taken from the same location: for example, where there has been a change in land ownership. ${ }^{88}$ The transfer is recorded by the Minister endorsing the name of the transferee on the licence. ${ }^{89}$

- Second, a licensee may enter into an agreement with a third party relating to the taking of water under the licence by the third party for a limited period of time. ${ }^{90}$ The Minister formalises this 'water lease' by recording on the licence the period of the agreement, the name of the third party and such other particulars as the Minister thinks fit. ${ }^{91}$

- Third, a water entitlement - that is, the quantity of water that a licensee is entitled to take under a licence ${ }^{92}$ - may be transferred to another person who holds, or is eligible to hold, a licence. This mechanism may be used, for example, where one landowner in a fully allocated groundwater management sub-area wants to purchase part of the water entitlement of another landowner in that sub-area. ${ }^{93}$ If the other person already has a licence the transfer is formalised by amending the transferring and receiving licence (e.g. by reducing the volumetric water entitlement by $50 \mathrm{ML} / \mathrm{yr}$ on one licence and increasing it by $50 \mathrm{ML} / \mathrm{yr}$ on the other). If the other person does not yet have a licence one will be issued and endorsed by the Minister with particulars of the transfer. ${ }^{94}$

As with the initial allocation of water a water trader must ordinarily be the owner or occupier of land from which the water is to be taken, or have the agreement of that person to be on the land and do

\footnotetext{
${ }^{85}$ Department of Water, 'Operational Policy 5.01: Managing Water Reserved for Use by Drinking Water Service Providers' (2011) 6-7.

${ }^{86}$ Rights in Water and Irrigation Act 1914 (WA) Sch $1 \mathrm{cl}$ 40; see also Government of Western Australia, 'Clause Notes to the Rights in Water and Irrigation Act 1914 (WA)' (1999)106. As discussed in Chapter 7, there are some drafting issues with this clause which may mean that it would not support the auction of water licenses.

${ }^{87}$ Rights in Water and Irrigation Act 1914 (WA) sch 1, cl 29(1)(a).

${ }^{88}$ Department of Water, Water Licensing Frequently Asked Questions

$<$ <ttp://www.water.wa.gov.au/Business+with+water/Water+licensing/Water+licensing+frequently+asked+questions/FAQ+ 4+Transfers+trades+and+agreements/default.aspx>

${ }^{89}$ Rights in Water and Irrigation Act 1914 (WA) sch 1, cl 36(a).

${ }^{90}$ Ibid sch $1 \mathrm{cl} 30$.

${ }^{91}$ Ibid sch $1 \mathrm{cl} 36$ (d). The Act does not use the term 'water lease' - it is used in this paper as a shorthand description.

92 Ibid sch $1 \mathrm{cl} 28$.

${ }^{93}$ Department of Water, above $\mathrm{n} 88$.

${ }^{94}$ Rights in Water and Irrigation Act 1914 (WA) sch 1 cl 36(b).
} 
there the things that may be done under the licence. ${ }^{95}$ This requirement was included in the Act to prevent the speculative acquisition of water rights. ${ }^{96}$

\section{Controls on well construction}

The RIWI Act regulates the construction and alteration of wells. It is generally an offence to construct or alter an artesian well or a non-artesian well in a proclaimed area, or to cause or permit this to happen, without a licence authorising that work. ${ }^{97}$ This applies both to the owner or occupier of the land and to persons engaged to carry out the work. ${ }^{98}$ As with the 'taking' provisions, exemptions may be granted for non-artesian wells, and have been granted for the purposes discussed above (e.g. domestic bores). ${ }^{99}$ The penalty for constructing or altering a well without a licence, or for breaching a condition of a licence, is a fine of up to $\$ 10,000$ (\$50,000 for corporations) plus a daily penalty of up to $\$ 1,000$ (\$5,000 for corporations). ${ }^{100}$

The RIWI Act also provides that a person who constructs or deepens a non-artesian well shall, within one month, provide a report in the prescribed form to the Minister or to such other person as the Minister may direct. ${ }^{101}$ Regulations prescribe the form of the report, which goes into some detail: the driller is to report, among other things, co-ordinates of the well, the intended use, the depth of the well, the water level and details of field samples (e.g. as to salinity). ${ }^{102}$ Importantly, while there is capacity to provide an exemption from this requirement, no exemptions have been granted. ${ }^{103}$ This means that reports should be provided for well construction and deepening in nonproclaimed areas and for otherwise exempt uses (e.g. domestic bores). The penalty for the offence is up to $\$ 1,000$ ( $\$ 5,000$ for corporations). ${ }^{104}$ These requirements have the potential to be a valuable source of information on unlicensed bores, but it is not clear that they are properly enforced, or that good use is made of information that is reported. ${ }^{105}$

\section{Controls on unlicensed water use}

The RIWI Act licensing scheme is the principal means by which groundwater use is regulated in Western Australia. However, basic regulatory controls do apply to some unlicensed groundwater use. These controls do not impose volumetric limits on the amount of water that can be taken, but they do restrict how water is used.

\footnotetext{
${ }^{95}$ Ibid sch 1 cl 29, 3(d).

${ }^{96}$ Government of Western Australia, above n 80, 79 ('The list of people eligible to hold licenses has been carefully drafted to avoid speculation in licences once trading has been introduced').

${ }^{97}$ Rights in Water and Irrigation Act 1914 (WA) s26A (artesian wells), s26B (non-artesian wells). Regulations may also apply this requirement to non-artesian wells outside proclaimed areas, but this has not been done: see Rights in Water and Irrigation Act 1914 (WA) s23B(3a), Rights in Water and Irrigation Act Regulations 2000 (WA).

${ }^{98}$ Rights in Water and Irrigation Act 1914 (WA) ss26A(2), 26B(6).

${ }^{99}$ See n 53-59 above.

${ }^{100}$ Rights in Water and Irrigation Act 1914 (WA) ss 26A, 26B; Sentencing Act 1995 (WA) ss 9, s 40(5).

101 Ibid s26E.

${ }^{102}$ Rights in Water and Irrigation Act Regulations 2000 (WA) reg 39, Schedule 3 Form 2.

${ }^{103}$ Capacity to grant exemptions is provided by $\mathrm{s} 26 \mathrm{E}(2)$, which provides that the Minister may, by notice published in the Gazette, exempt persons from the requirement of complying with s26E(1).

${ }^{104}$ Rights in Water and Irrigation Act 1914 (WA) ss 26E; Sentencing Act 1995 (WA) ss 9, s 40(5).

${ }^{105}$ For example, it appears that surveys rather than information from s26E reports is used to estimate the number of dwellings using garden bores: Department of Water, 'Operational Policy 5.17 - Metropolitan Domestic Garden Bores' (2011) 7-8.
} 
Under the Water Agencies (Powers) Act 1984 (WA) by-laws may 'prohibit, impose restrictions on or otherwise regulate the use of water'. ${ }^{106}$ Offences created under such by-laws may carry a maximum penalty of $\$ 2000$ ( $\$ 10,000$ for corporations), with an additional penalty of up to $\$ 200$ per day (\$1,000 for corporations) for continuing offences. ${ }^{107}$

Pursuant to these provisions, the Water Agencies (Powers) By-Laws 2010 impose restrictions on the use of groundwater from unlicensed 'domestic bores'. ${ }^{108}$ A 'domestic bore' is defined as 'a nonartesian well ... from which the only water that can be taken is from the water table aquifer'. ${ }^{109}$

The by-laws contain seven stages of water restrictions. Stage one water restrictions impose modest constraints on the watering of lawns, gardens and sporting grounds. Reticulated watering is restricted to once a day, in either the morning or evening ${ }^{110}$ At the other extreme, stage seven water restrictions prohibit watering of lawns, gardens and sporting grounds except by handheld watering can. The use of water in other activities, such as the use of high pressure water cleaners, the filling of swimming pools and the washing of motor vehicles is also prohibited or severely restricted. ${ }^{111}$

Clearly, the intent of the by-laws is to establish a flexible framework under which watering practices can be modified in the light of changing conditions. At present under the by-laws, different levels of restrictions apply in different areas of the State. For Perth and Mandurah, watering of lawns, gardens or sporting grounds is prohibited in the winter months of June, July and August. In the other months reticulated watering is limited to the morning or evening period three times per week.

The maximum penalty for a breach of the by-laws is $\$ 500$ for natural persons and $\$ 2,500$ for corporations. $^{112}$

\subsection{Water law reform in Western Australia}

The RIWI Act was subject to its last round of major amendments in $2001 .{ }^{113}$ Since that time there have been a number of developments in national and state policy.

One major development has been the Intergovernmental Agreement on a National Initiative, ${ }^{114}$ which was signed by most States and Territories in 2004 and by Western Australia in 2006. Among other things, the agreement includes commitments to:

- statutory water planning directed at achieving environmentally-sustainable levels of extraction;

- returning over-allocated and over-used water resources to sustainable levels of abstraction;

- secure, statutory provision for environmental and other public benefit outcomes;

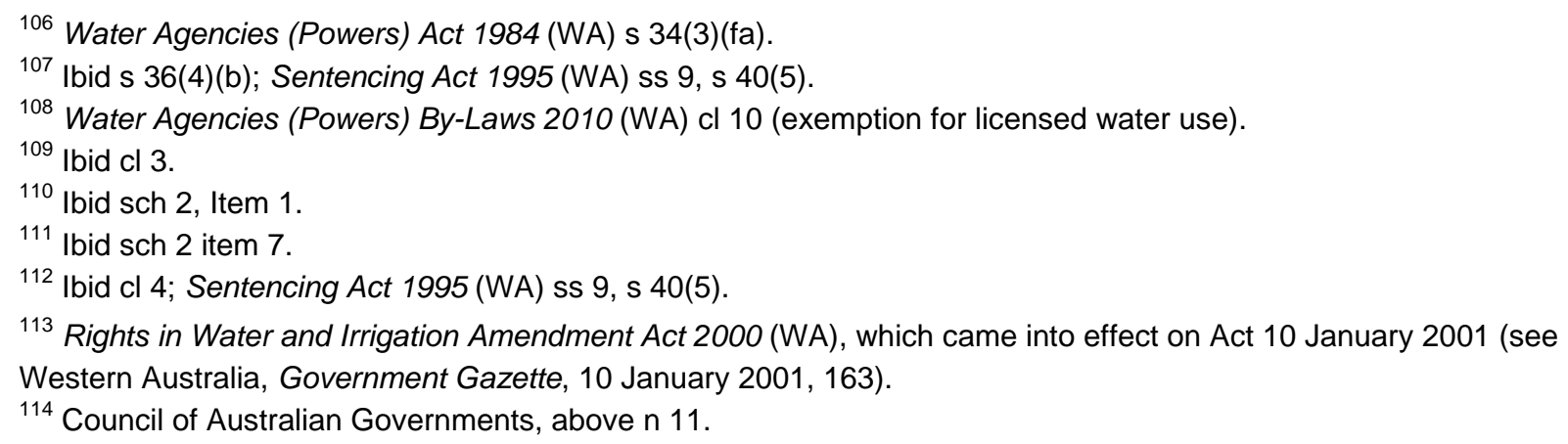


- establishing a new system of water entitlements that gives the holder of the entitlement a perpetual share of a consumptive pool and identifies a 'risk assignment framework' for changes in that consumptive pool;

- increased use of market-based mechanisms for the release of water entitlements; and

- reduced barriers to trade of water entitlements.

In 2006, a report by the Water Reform Implementation Committee, entitled 'A Blueprint for Water Reform in Western Australia' broadly endorsed the National Water Initiative reform program, with a particular emphasis on reform of water entitlements and increased water trading. ${ }^{115}$ The State Government accepted these recommendations, with some refinements, in 2007.

In late 2009 a new State Government released a Discussion Paper with a detailed set of reform proposals that were largely consistent with the National Water Initiative ('National Water Initiative') commitments outlined above. ${ }^{116}$ Policy development slowed from this point, but in September 2013 the Government released a Position Paper on reforming water resource management ('2013 Position Paper') with a similar set of reform proposals, ${ }^{117}$ with a view to drafting new water resource management legislation in $2014 .^{118}$

One of the purposes of this Report is to inform the development of, and debate on, this proposed legislation and subsidiary legislation that will follow. Reform proposals in the 2013 Position Paper are discussed in subsequent chapters of the Report.

\footnotetext{
${ }^{115}$ Water Reform Implementation Committee, 'A Blueprint for Water Reform in Western Australia: Final Advice to the Western Australian Government' (2006).

${ }^{116}$ Government of Western Australia, 'Discussion Paper: Water Resources Management Options' (2009).

${ }^{117}$ Department of Water, above n 70.

${ }^{118}$ Department of Water, Reforming Water Resource Management - Position Paper for Public Consultation: Frequently Asked Questions (17 February 2013) < http://www.water.wa.gov.au/PublicationStore/first/106022.pdf>.
} 


\section{Groundwater challenges in a drying South West}

\subsection{Water resources of the South West}

For the purposes of this paper, the South West of Western Australia is the area identified in Figure 1 , stretching from Geraldton in the north to Albany in the south. It covers some $62,500 \mathrm{~km}^{2}$ and contains around 2 million people - 90 per cent of the population of Western Australia. ${ }^{119}$ We will not describe the hydrogeology of the South West, as this has been done comprehensively elsewhere. ${ }^{120}$ However, we make the overarching point that while the South West contains substantial groundwater resources, they vary substantially in quality and there are a variety of constraints on their use.

For example, the Leederville and Yarragadee aquifers beneath Perth collectively store an enormous quantity of water - more than half a million GL. ${ }^{122}$ However most of this water is not fresh: see Figure 3. Concerns about the impact of current rates of extraction on surface wetlands and saline intrusion mean that the Leederville and Yarragadee aquifers beneath Perth are considered fully allocated. ${ }^{123}$

Groundwater is the most important water source for consumptive use in the South West. In 2009,

groundwater use in the South West was estimated to be 850 gigalitres per year (GL/yr), which was at that time about three quarters of all water used. ${ }^{124}$ The main uses are for drinking water supplies in Perth and towns, and self-supply for the irrigation of public and private lawns and gardens, horticulture, industry and commerce. ${ }^{125}$

Self-supply from groundwater is very significant. We estimate that self-supply is in the order of $700 \mathrm{GL} / \mathrm{yr}$ (with the remaining $150 \mathrm{GL} / \mathrm{yr}$ of the $850 \mathrm{GL} / \mathrm{yr}$ being

Figure 3: Yarragadee aquifer salinity levels ${ }^{121}$

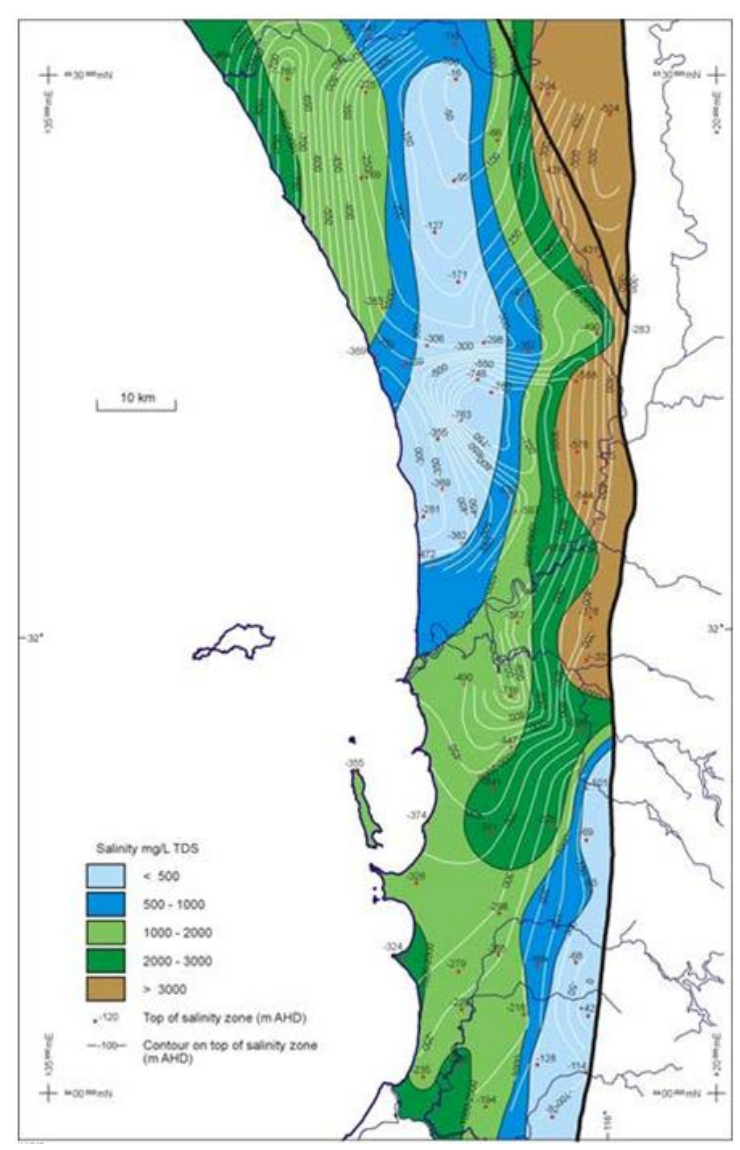

\footnotetext{
${ }^{119}$ CSIRO, above n 2, iv.

${ }^{120}$ CSIRO, 'Groundwater yields in south-west Western Australia: A report to the Australian Government from the CSIRO South-West Western Australia Sustainable Yields Project' (2009), Chapter 3.

${ }^{121}$ Source: Presentation by Philip Commander, Adjunct Associate Professor, University of Western Australia, 2012.

122 It has been estimated that there is $76000 \mathrm{GL}$ of fresh water and $370000 \mathrm{GL}$ of brackish water in the Yarragadee aquifer beneath the Perth region, and $120000 \mathrm{GL}$ of mostly fresh groundwater within the Leederville aquifer: Department of Water, 'Policy on Accessing the Leederville and Yarragadee aquifers in Perth' (2006) 17, 18.

${ }^{123}$ Ibid 6.

${ }^{124}$ CSIRO, above n 2, 126.

125 Ibid.
} 
taken by water utilities as a source of public water supply). ${ }^{126}$ This can be compared to public water supply, sourced from groundwater, surface water and desalinated seawater, of less than 350 GL/yr. ${ }^{127}$ This underlines the importance of self-supply from groundwater: South West water users take more than twice as much water directly from the ground than they get from the public water supply tap.

Alongside consumptive uses, the South West's water resources also support areas of great environmental significance. The South West of Western Australia has been identified as one of 25 global 'biodiversity hotspots'. ${ }^{128}$ It includes six wetlands listed as internationally significant under the Ramsar Convention, ${ }^{129}$ other conservation category wetlands and areas containing nationallylisted threatened species and ecological communities that are dependent on groundwater flows for their survival. ${ }^{130}$ Groundwater flows also support socially significant surface water systems - the Blackwood River is one example. ${ }^{131}$

\footnotetext{
${ }^{126}$ We arrived at the $700 \mathrm{GL} / \mathrm{yr}$ estimate by taking the CSIRO figure of $850 \mathrm{GL} / \mathrm{yr}$ for total groundwater use the South West and deducting our estimate, based on published figures from relevant water utilities for major water supply schemes, of around 150GL/yr of South West groundwater being used for public water supply: Water Corporation, 'Annual Report 2013' (2013) 6 (140.2 GL of groundwater extracted for the Integrated Water Supply Scheme, 2012-13); Aqwest, 'Annual Report 2013' (2013) (6.33GL of groundwater extracted for Bunbury's water supply in 2012-13); Busselton Water, 'Annual Report 2012-2013' (Annual Report) 81 (4.6GL extracted for Busselton and its environs in 2013). Groundwater is also used for public water supply in some other regional towns (e.g. Albany and Bridgetown), which would increase this total, but this may be offset by reduced extraction for the Integrated Water Supply Scheme in 2013-14 as desalinated water supply increased.

127 Water Corporation, above n 126, 45 (278GL to Perth Region, 14.3GL to the South West; also 18.1GL and 10.8GL for the Great Southern and Mid-West Regions respectively, parts of which fall within our South West project area);

Aqwest, above n 126; Busselton Water, above n 126.

${ }^{128}$ Norman Myers et al, 'Biodiversity hotspots for conservation priorities' (2000) 403 Nature 853.

${ }^{129}$ These wetlands are the Forrestdale and Thomsons Lakes; the Peel-Yalgorup System; the Becher Point Wetlands; the Vasse-Wonnerup System; and the Muir-Byenup System: see Australian Government, Australia's Ramsar Sites $<$ http://www.environment.gov.au/water/publications/environmental/wetlands/pubs/ramsar.pdf>.

${ }^{130} \mathrm{P}$. Horwitz et al, 'Hydrological change escalates risk of ecosystem stress in Australia's threatened biodiversity hotspot' (2008) 91 Journal of the Royal Society of Western Australia 7.

${ }^{131}$ Sinclair Knight Mertz, 'Evolving issues and practices in groundwater-dependent ecosystem management' (National Water Commission, 2011) 70.
} 


\subsection{The drying trend and its impacts on water resources}

\section{The drying trend}

Since 1970 there has been a 17 per cent decline in average winter rainfall in the southwest of Australia: see Figures 4-6. ${ }^{132}$ There have also been less of the 'wet' winters that normally replenish reservoirs, superficial aquifers and wetlands after they have been drawn down in drier years. ${ }^{133}$

Figure 4: Rainfall trend in Western Australia (1970-2012,mm/10yrs) ${ }^{134}$

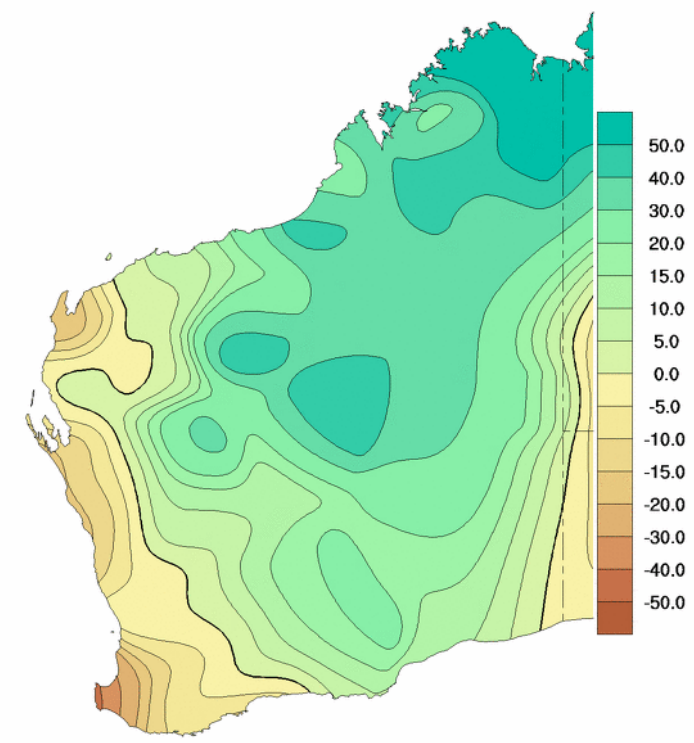

Figure 5: Annual rainfall in SWWA (1900-2013) ${ }^{135}$
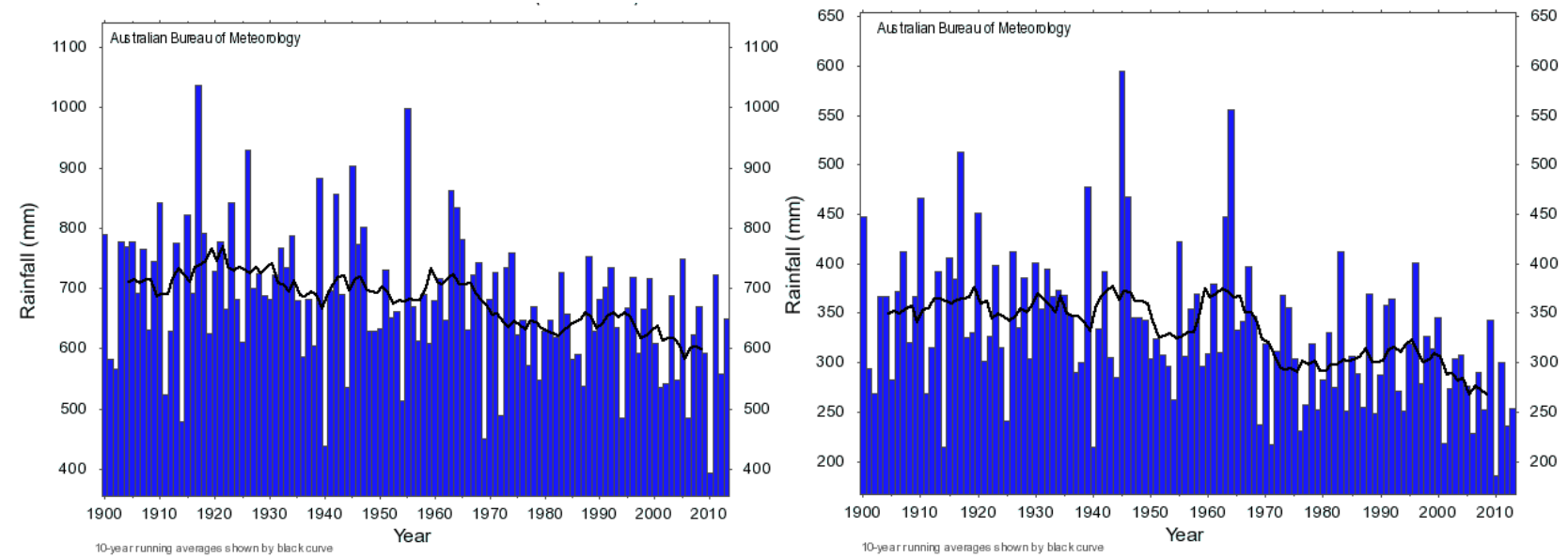

\footnotetext{
${ }^{132}$ CSIRO and Bureau of Meteorology, 'State of the Climate 2014' (Australian Government, 2014) 6.

133 Sadler, above n 1, 1; CSIRO and Bureau of Meteorology, above n 132, 6.

${ }^{134}$ Source: Bureau of Meteorology, Australian Climate Variability and Change - Trend Maps (2013) $<$ http://www.bom.gov.au/climate/change>

135 Source: Bureau of Meteorology, Australian Climate Variability and Change - Trend Maps (2013) $<$ http://www.bom.gov.au/climate/change>. The black line represents the 10-year running average. ${ }^{136}$ Source: Bureau of Meteorology, Australian Climate Variability and Change - Trend Maps (2013) $<$ http://www.bom.gov.au/climate/change >. The black line represents the 10-year running average.
} 


\section{The role of human-induced climate change}

Peer-reviewed scientific papers have explored a number of possible causes for reduced rainfall in South West Western Australia, including land-cover change ${ }^{137}$, multi-decadal variations ${ }^{138}$ and human-induced climate change. ${ }^{139}$ One study suggests that human-induced climate change contributes to about $50 \%$ of the observed rainfall decline. ${ }^{140}$

In its 2012 brief to policy makers, the Indian Ocean Climate Initiative (a joint initiative of the WA Government, CSIRO and the Bureau of Meteorology) outlined the results of its research. The brief concluded that the observed patterns of large-scale atmospheric change associated with South West rainfall reductions, involving a contraction of strong westerly winds towards the South Pole, are consistent with what would be expected in an atmosphere influenced by increasing greenhouse gas concentrations. ${ }^{141}$

Consistent with the Indian Ocean Climate Initiative's findings, the Intergovernmental Panel on Climate Change's report Climate Change 2014: Impacts, Adaptation, and Vulnerability stated that '[o]ver the past 50 years, increasing greenhouse gas concentrations have contributed to...decreasing rainfall in south-western Australia (high confidence). ${ }^{142}$

\section{Impacts on surface water resources}

Because streamflow only occurs once a soil saturation threshold is reached, reduced rainfall has a substantial impact on streamflow: see Figure $7 .{ }^{143}$ Since the mid-1970s average streamflow into the major water supply reservoirs in the South West has declined by more than 50 per cent. ${ }^{144}$

\footnotetext{
${ }^{137}$ A J Pitman et al, 'Impact of land cover change on the climate of southwest Western Australia' (2004) 109(D18) Journal of Geophysical Research; Mark A. Andrich and Jörg Imberger, 'The effect of land clearing on rainfall and fresh water resources in Western Australia: a multi-functional sustainability analysis' (2013) 20(6) International Journal of Sustainable Development \& World Ecology 549.

${ }^{138}$ Wenju Cai and Je Shi, 'Multidecadal fluctuations of winter rainfall over southwest Western Australia simulated in the CSIRO Mark 3 coupled model' (2005) 32(12) Geophysical Research Letters

${ }^{139}$ B. Tindal, J. M. Arblaster and S Power, 'Attribution of the Late-Twentieth-Century Rainfall Decline in Southwest Australia' (2006) 19 Journal of Climate 2046; Wenju Cai and Tim Cowan, 'SAM and regional rainfall in IPCC AR4 models: Can anthropogenic forcing account for southwest Western Australian winter rainfall reduction?' (2006) 33(24) Geophysical Research Letters

${ }^{140}$ Cai and Cowan, above n 139.

${ }^{141}$ Indian Ocean Climate Initiative, 'Indian Ocean Climate Initiative Stage 3: Summary for Policymakers' (CSIRO and BoM, 2012) 9-10.

142 Intergovernmental Panel on Climate Change, 'Climate Change 2014: Impacts, Adaptation, and Vulnerability' (2014) Ch 25, 3.

143 Jane Chambers et al, 'Adapting to climate change: a risk assessment and decision making framework for managing groundwater dependent ecosystems with declining water levels' (National Climate Change Adaptation Research Facility, 2013); Kevin C. Petrone et al, 'Streamflow decline in southwestern Australia, 1950-2008' (2010) 37(11) Geophysical Research Letters 1, 3.

${ }^{144}$ R P Silberstein et al, 'Climate change and runoff in south-western Australia' (2012) 475 Journal of Hydrology 441, 442. See also M L Berti et al, 'Climate Change, Catchment Runoff and Risks to Water Supply in the South-West of Western Australia' (2004).
} 
Figure 7: Streamflow to Perth Dams (1911-2011) ${ }^{145}$

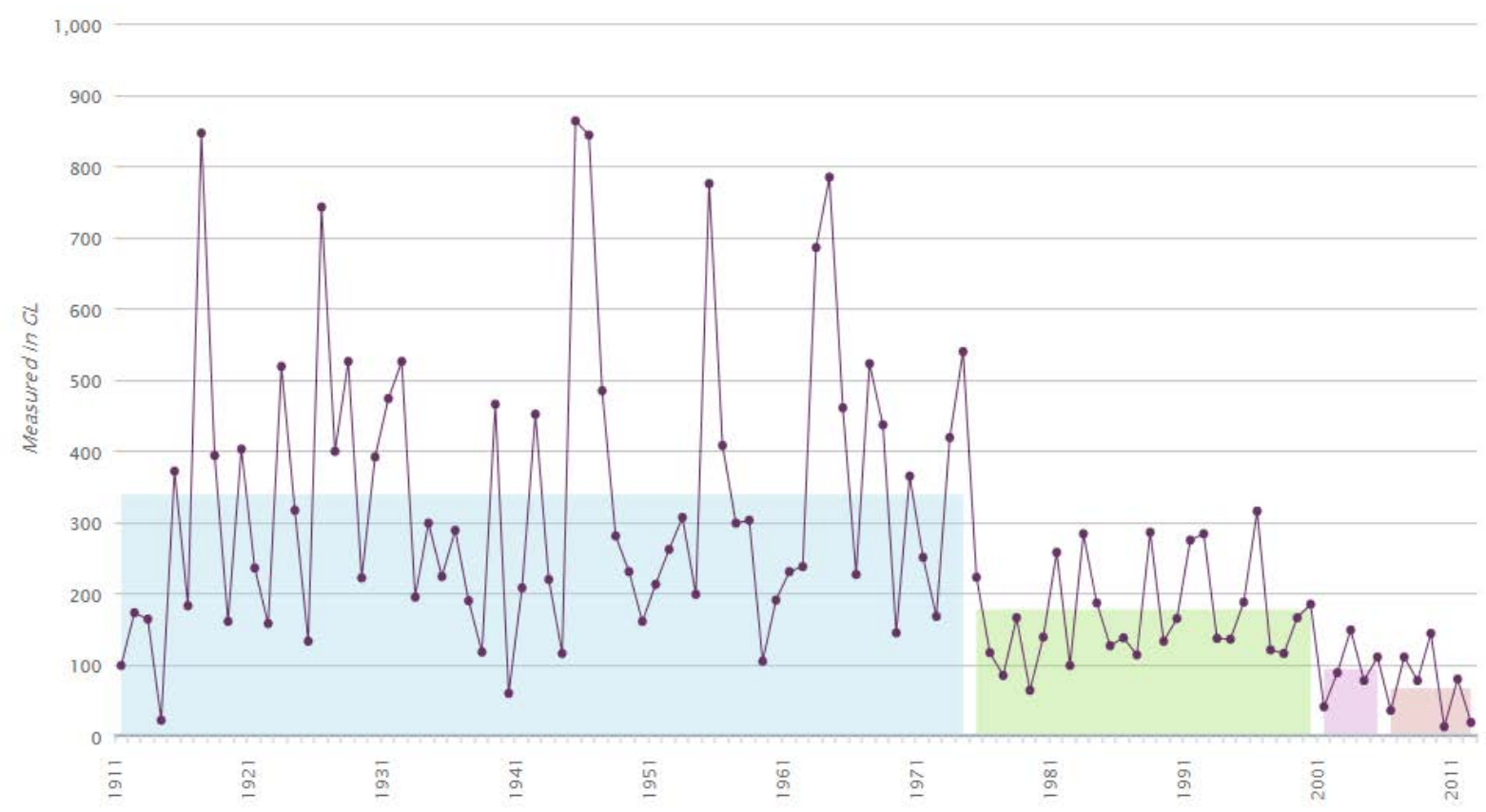

\section{Public water supply response to reduced streamflow}

While not the focus of this research, mention does need to be made of the public water supply response to the collapse in streamflow experienced since the mid-1970s. This response provides important context, as it had significant implications for groundwater management. We focus here on the response for Perth and other areas serviced by the Integrated Water Supply System - both because this is the largest public water supply system in the South West, and because of the important implications this has for groundwater demand in the South West.

Ever since of C Y O'Connor's 'golden pipeline' succeeded in moving water from the Perth Hills to the Goldfields, big water engineering projects have had a hold on the Western Australian imagination. ${ }^{146}$ When Perth's dams themselves became unreliable due to reduced streamflow from the mid-1970s, the State Government turned to engineering solutions again, but this time the water source was closer to home. In the 1960s the Public Works Department had identified extensive groundwater stocks within two superficial aquifers: the Gnangara Mound, located north of Perth's Swan River; and the Jandakot Mound, located to the south of the Swan River. ${ }^{147}$ The timing of this discovery and the location of these groundwater resources was fortuitous. As Morgan

\footnotetext{
${ }^{145}$ Source: Water Corporation, Historical Streamflow (27 March 2014) <http://www.watercorporation.com.au/watersupply-and-services/rainfall-and-dams/streamflow/streamflowhistorical>.

${ }^{146}$ During the 1890 s gold rush a water shortage developed in the Goldfields east of Perth. In a substantial engineering feat for the time, the solution was the 560km 'Golden Pipeline', opened in 1903, to move water from Perth's Mundaring Weir Dam to Kalgoorlie: Godfrey Lowe, 'The Golden Pipeline' (2004) 2(1) Australian Journal of Multi-disciplinary Engineering 45.

${ }^{147}$ Ruth A Morgan, Running out? An environmental history of climate and water in the southwest of Western Australia, 1829 to 2006 (PhD Thesis, University of Western Australia, 2012) 162-163.
} 
has noted, 'this subterranean treasure trove was almost exactly aligned with the coastal ribbon of Perth's post-war development. ${ }^{148}$

The use of groundwater for public water supply sharply increased over following decades: initially from the superficial Gnangara and Jandakot aquifers, but later - as water levels in the superficial aquifers declined - from the deeper, more confined Leederville and Yarragadee aquifers. By 1998 the Water Corporation was using oil-field technology to draw water more than one kilometre from the Yarragadee aquifer beneath Perth ${ }^{149}$ and by 2001 a national assessment of water resources found that the Leederville and Yarragadee aquifers were fully allocated in the Perth area. ${ }^{150}$

Figure 8: Water sources for the Integrated Water Supply System (1940-2023) ${ }^{151}$

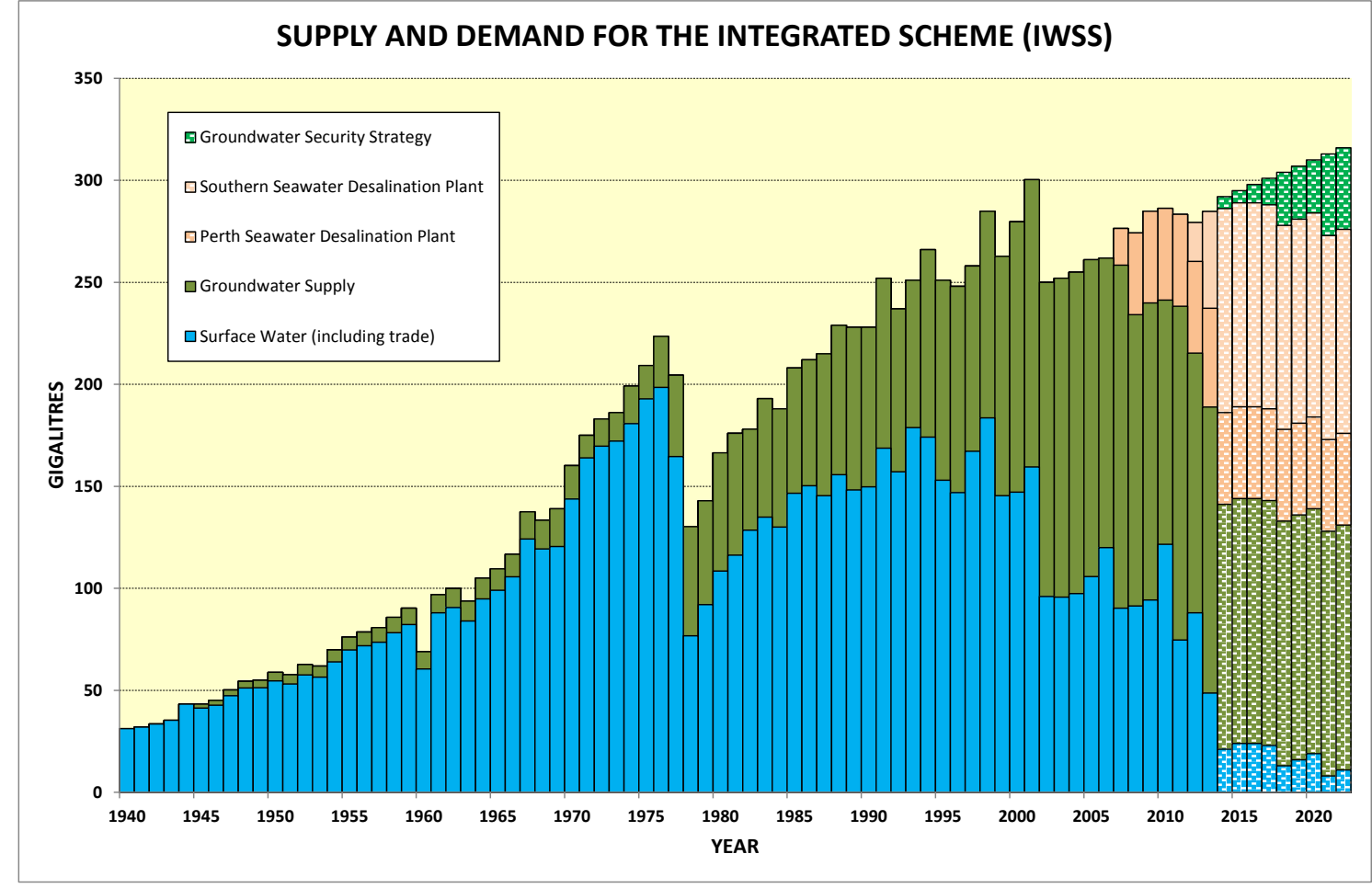

What would the next water source be? Abstraction from the South West Yarragadee aquifer south of Perth was considered, but rejected due to community concerns about the impacts on the South West economy and environment - concerns that were heightened by the experience of declining water levels on the Gnangara Mound. ${ }^{152}$ A 3,7000km canal to bring water from Kimberley's Fitzroy River was proposed, but was too costly and impractical. ${ }^{153}$ The eventual solution was seawater desalination. Two desalination plants were opened, in Kwinana (2006) and Binningup (2011), ${ }^{154}$

\footnotetext{
148 Ibid 164.

${ }^{149}$ Water Corporation, Water Story: The Battle to Keep Perth Green (Water Corporation, 2007) 22.

${ }^{150}$ Commonwealth of Australia, 'Australian Water Resource Assessment 2000' (2001); Department of Water, above n 122, 6 .

${ }^{151}$ Source: This graphic was kindly provided by the Water Corporation for this research project (24 July 2013).

152 Morgan, above n 147, 269-271.

153 Ibid 273-4; Kimberley Expert Panel, 'Options for Bringing Water from Perth to the Kimberley' (2006).

${ }^{154}$ Morgan, above n 147, 278, 281.
} 
and by 2013 the Binnungup plant had been expanded to double its capacity: ${ }^{155}$ See Figure 8. These desalination plants have the capacity to provide $150 \mathrm{GL} / \mathrm{yr}$ - about half of Perth's annual water needs. ${ }^{156}$

The latest major addition to the portfolio of water sources is treated wastewater. In 2013 , following a successful three year trial, the State Government announced that 'groundwater replenishment', involving the injection of treated wastewater into aquifers and a corresponding increase in groundwater abstraction, would become an ongoing water source, initially supplying $7 \mathrm{GL} / \mathrm{yr} .{ }^{157}$ This managed aquifer recharge project, which has the advantage of using significantly less energy than seawater desalination, has received bipartisan political support and is likely to become an increasingly important water source.

The engineering solutions of groundwater extraction, desalination and managed aquifer recharge are not the whole story. Substantial volumes of water have been saved through demand management measures including garden sprinkler restrictions and water use efficiency programs, and a water trade with South West irrigators was a timely addition to public water supply. It is undoubtedly the case, however, that rapid development of groundwater sources and desalination have been the main reason that public water supply has been able to continue at close to 'business as usual' levels alongside such a substantial decline in streamflow. Without good planning combined with the good fortune of groundwater sources, a coastal location suitable for desalination and the billions of dollars needed to develop these water sources, Perth's water story could have been very different.

There is one more important point about water source development for present purposes: that climate change projections have played an important role in water supply planning for more than three decades. In a controversial decision at the time, water supply plans were amended in the late 1980 s on the assumption that climate change would see continued declines in rainfall in the South West. ${ }^{158}$ Water supply planning proceeded on the basis that dryer conditions were the 'new normal' rather than a temporary anomaly. As Morgan discusses in her careful analysis of the role climate change projections played in water supply planning in this period, the Water Authority of WA decided to adopt a precautionary approach in the face of tentative projections of a drying South West. After all, 'if the WAWA invested in infrastructure for lower winter rainfall but the predictions were not fulfilled, the consequences would be less disastrous than if they had invested for higher winter rainfall and received less. ${ }^{, 159}$ This precautionary approach influenced both the timing of water source development and the preference for rainfall-independent water sources including (in

\footnotetext{
155 'Premier says desal will 'drought-proof' Perth', Australian Broadcasting Corporation 23 February 2013 <http://www.abc.net.au/news/2013-01-23/second-stage-of-desalination-plant-opened/4480588>.

${ }^{156}$ Water Corporation, Desalination (2013) <http://www.watercorporation.com.au/water-supply-and-services/solutions-toperths-water-supply/desalination>.

${ }^{157}$ Hon Terry Redman MLA, Advanced Recycling to Help Secure Water Supply 1 August 2013 $<$ http://www.mediastatements.wa.gov.au/pages/StatementDetails.aspx?listName=StatementsBarnett\&Statld=7615>

${ }^{158}$ Brian Sadler, 'Climate Change and Water from the Sea' (2009) <http://www.connectedwaters.unsw.edu.au/articles/2009/03/climate-change-and-water-sea>.

${ }^{159}$ Ruth Morgan, 'Dry Horizons: The Responses of Western Australian Water Managers to the Enhanced Greenhouse Effect in the Late 1980s' (2011) 8(3) History Australia 158, 170.
} 
recent years) desalination. ${ }^{160}$ As we shall see in the next chapter, climate change projections were not incorporated so rapidly into groundwater allocation planning.

\section{Impacts of the drying South West on groundwater resources}

The impact of reduced rainfall on groundwater resources has been significant. There has been a direct impact through reduced recharge to aquifers. For example, it has been estimated that reduced rainfall between 1979 and 2005 was responsible for falls of up to 4 metres in the important Gnangara superficial aquifer north of Perth. ${ }^{161}$ As we shall see in a case study later in this report, this has had a major adverse impact on the wetlands in the region. Reductions in recharge associated with declining rainfall has also been a driving factor behind occurrences of seawater intrusion in a number of South West aquifers, including Perth (Cottesloe Peninsula), Bunbury and Busselton. ${ }^{162}$

There has also been an indirect impact through increased demand for groundwater, both from the Water Corporation for public water supply ${ }^{163}$ and from private users of groundwater bores, ${ }^{164}$ to fill the gap left by declining streamflow. Taken together, reduced recharge and increased abstraction have had a significant effect on groundwater resources. Two important examples in the Perth region are the depletion of the superficial Gnangara Mound (Figure 9) and the deeper Yarragadee aquifer (Figure 10).

\footnotetext{
${ }^{160}$ Desalination is often referred to as 'climate-independent', but given the heavy energy use associated with desalination 'rainfall-independent' may be more appropriate, particularly for the first desalination plant which lacked effective carbonoffsetting arrangements. On the latter point, see Auditor General for Western Australia, 'Renewable Energy: Knowing What We Are Getting' (Report 12, 2007) 21 ('the contractual arrangement to power the desalination plant does not ensure that additional renewable energy is generated').

${ }^{161}$ Cahit Yesertner, 'Assessment of the declining groundwater levels in the Gnangara Groundwater Mound' (Department of Water, 2008), $\mathrm{p}$ v.

${ }^{162}$ KM Ivkovic et al, 'National-scale Vulnerability Assessment of Seawater Intrusion: Summary Report' (2012) 16.

${ }^{163}$ Extraction for public water supply from the Gnangara groundwater system expanded substantially to approximately 142GL in 2008, in part due to reduced availability of surface water: James H. Skurray, E. J. Roberts and David J. Pannell, 'Hydrological challenges to groundwater trading: Lessons from south-west Western Australia' (2012) 412-413 Journal of Hydrology 256, 258.

164 There was a rapid increase in the number of private bores in response to water use restrictions imposed in the late 1970s.Water and Rivers Commission, Water Facts 12 (August 1998), Department of Water <http://www.water.wa.gov.au/PublicationStore/first/10256.pdf>.
} 
Figure 9: Gnangara Mound (superficial aquifer) depletion (1979-2009) ${ }^{165}$

Year

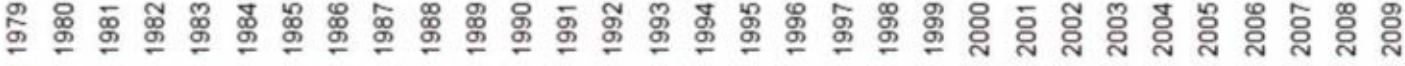

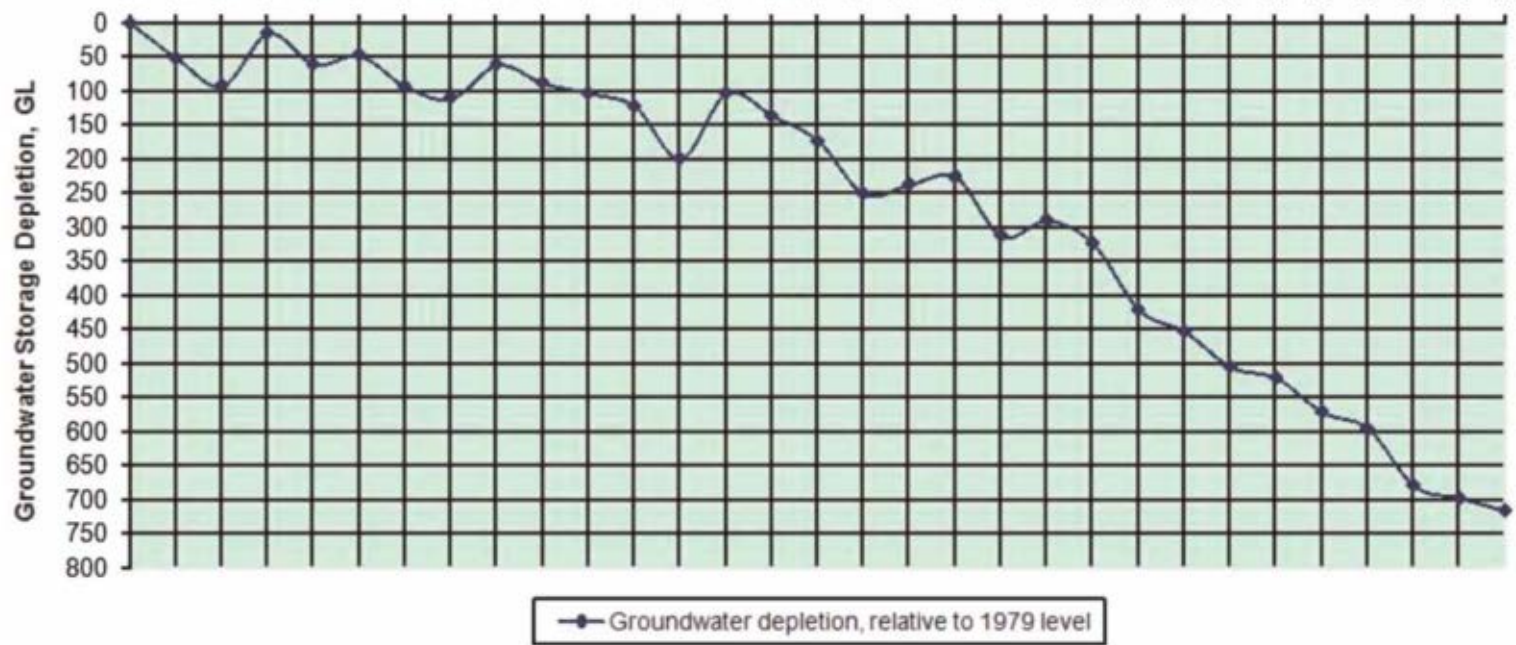

Figure 10: Yarragadee Aquifer (deeper aquifer) pressure levels (1973-2011) ${ }^{166}$

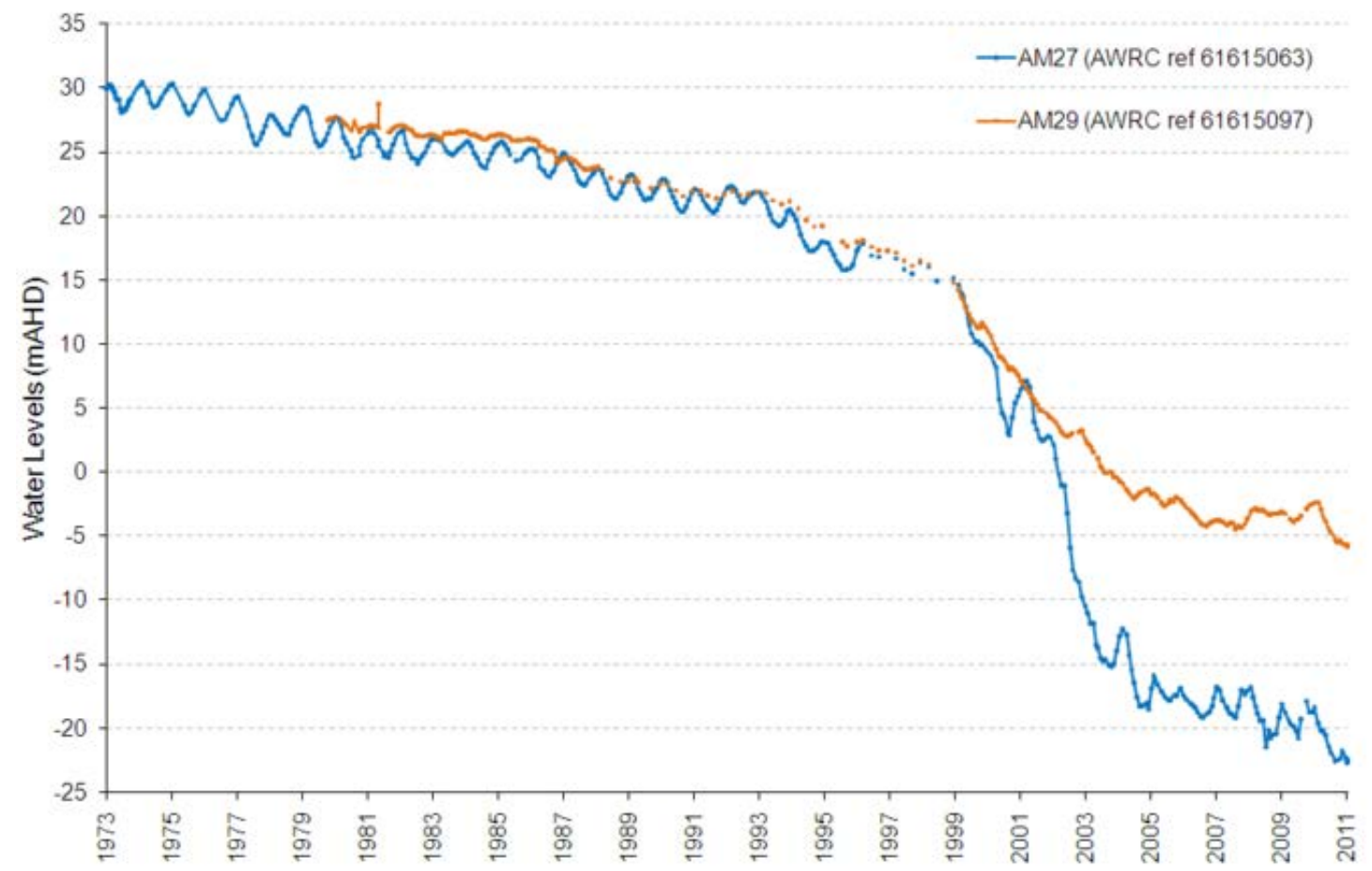

It needs to be appreciated, however, that rainfall is not the only factor that affects recharge of groundwater aquifers: the amount of surface vegetation, for example, is another very important factor. In some cleared areas the effect of reduced rainfall has been a slowing of the rate at which the water table has risen, rather than a decline in the water table. As a result, water table trends in

\footnotetext{
${ }^{165}$ Source: Don McFarlane et al, 'Managing groundwater levels in the face of uncertainty and change: a case study from Gnangara' (2012) 12(3) Water Science \& Technology: Water Supply 321, 325.

${ }^{166}$ Source: Department of Water, 'Gnangara Groundwater Areas Allocation Plan: Evaluation statement 2009—2011' (2011) 7.
} 
recent decades present a mixed picture, with reductions in some areas and increases in others: see Figure 11.

Figure 11: Water table trend in the southern Perth Basin (1980-2007) ${ }^{167}$

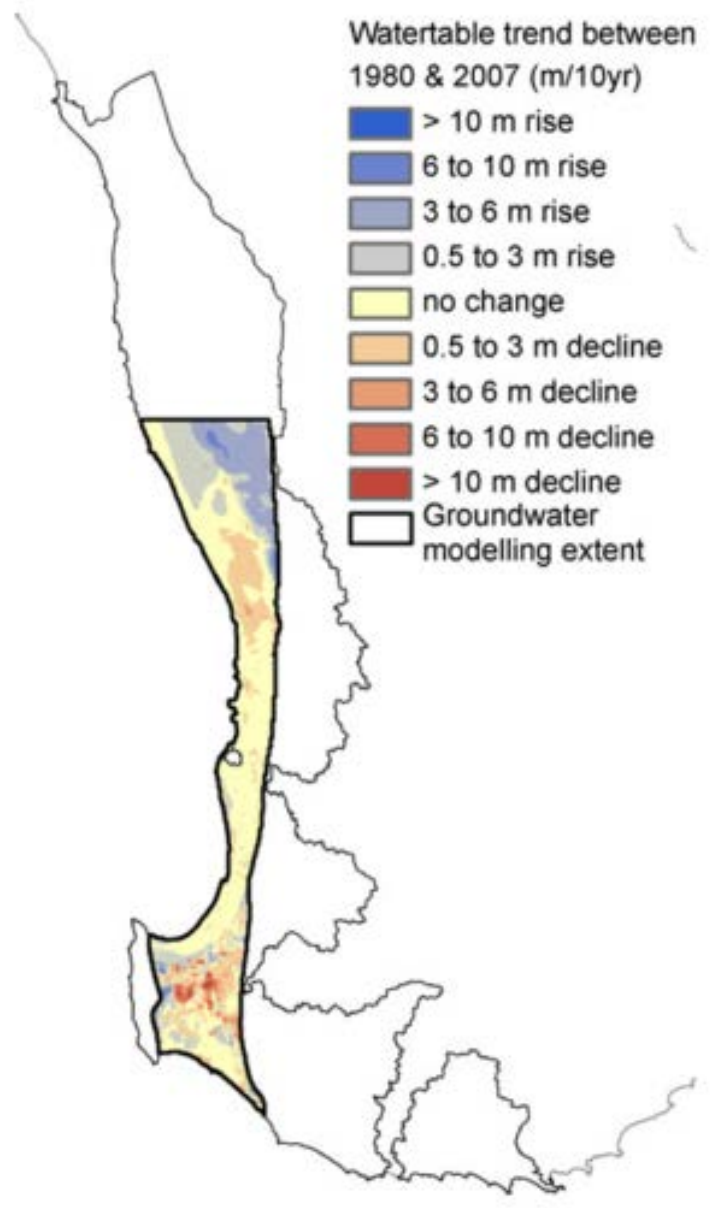

\section{Over-allocation and over-use in the South West}

According to the Intergovernmental Agreement on a National Water Initiative ('National Water Initiative') a resource is over-allocated when 'the total volume of water able to be extracted by entitlement holders at a given time exceeds the environmentally sustainable level of extraction for that system'. ${ }^{168}$ A resource is over-used 'where the total volume of water actually extracted for consumptive use in a particular system at a given time exceeds the environmentally sustainable level of extraction for that system. ${ }^{169}$ So the first term relates to authorised abstraction; the second actual extraction; and in both cases the 'environmentally sustainable level of extraction' is the baseline against which over-allocation or over-use is to be measured.

How over-allocated are groundwater resources in the South West? This is a difficult question to answer in a way that is strictly consistent with the National Water Initiative definitions, because the formal allocation limit does not necessarily represent an 'environmentally sustainable level of

167 Source: Riasat Ali et al, 'Potential climate change impacts on groundwater resources of south-western Australia' (2012) 475 Journal of Hydrology 456, p459 (Fig 3).

${ }^{168}$ Council of Australian Governments, above n 11, Sch B(i).

169 Ibid. 
extraction'. ${ }^{170}$ However a comparison of total licenced use with existing allocation limits does provide some basis for assessment. Table 3 provides an overview comparison, and Appendix $\mathbf{F}$ a detailed breakdown of over-allocated groundwater resources.

Table 3: Recognised over-allocation in South West groundwater management areas (2014)

\begin{tabular}{|l|c|c|c|}
\hline & $\begin{array}{c}\text { Number of over- } \\
\text { allocated } \\
\text { management units }\end{array}$ & $\begin{array}{c}\text { Total number of } \\
\text { management units }\end{array}$ & $\begin{array}{c}\text { Percentage of } \\
\text { management units } \\
\text { over-allocated }\end{array}$ \\
\hline Gnangara & 26 & 84 & $31 \%$ \\
\hline Cockburn & 2 & 7 & $29 \%$ \\
\hline Upper Collie & 3 & 12 & $25 \%$ \\
\hline South West & 9 & 60 & $15 \%$ \\
\hline Gingin & 5 & 40 & $12 \%$ \\
\hline Rockingham-Stakehill & 1 & 8 & $12 \%$ \\
\hline Murray & 1 & 20 & $5 \%$ \\
\hline
\end{tabular}

How over-used are groundwater resources in the South West? This is an even more difficult question to answer, as it requires an assessment of actual use. Unfortunately, there are only a few water resources in the South West that have sufficient metering coverage to enable an assessment of over-use. One of these is the Gnangara groundwater area, where sampling of government-owned bores suggests that total metered abstraction is less than total licenced abstraction. ${ }^{171}$ This provides some comfort that, for Gnangara at least, over-use is less extensive than over-allocation.

What is clear is that there are significant over-allocation problems, and likely over-use problems, for some South West groundwater resources. The drying South West climate has been a significant contributing factor. For example, some management units in the Gnangara system became classified as over-allocated in 2009 when allocation limits (but not licensed entitlements) were reduced to reflect reductions in groundwater recharge. ${ }^{172}$ This is a clear example of how over-allocation can come about in a drying climate: allocation limits that are based on out-dated assumptions of rainfall and recharge can, when adjusted downwards, mean that total licenced entitlements exceed the adjusted allocation limit.

\footnotetext{
${ }^{170}$ See discussion in section 1.3 above.

${ }^{171}$ A sample of government-owned bores in 2009-10 showed that metered abstraction was 63\% of licenced abstraction; a sample in 2010-11 (including the very dry winter of 2010) showed that metered abstraction was $87 \%$ of licenced abstraction: Department of Water, above n 166, 10-11.

172 In 2005 allocation limits across the Gnangara system, as recorded in the Department of Water's Water Resource Licensing Database, added up to $337 \mathrm{GL}$. In 2009 allocation limits were revised in order to better reflect recharge from rainfall. Total allocation limits were reduced to $304 \mathrm{GL}$ and 21 management sub-areas became classified as overallocated. In 2013 allocation limits were reduced further, but no additional sub-areas were classified as over-allocated as a result: pers comm Trudy Evans, Department of Water, 14 August 2013. Department of Water, above n 33, 37 (acknowledging that there is a need to reduce abstraction 'towards a level that better reflects the current recharge from rainfall.')
} 


\subsection{Future scenarios for groundwater in the South West}

Climate change will affect precipitation patterns differently in different parts of the world. ${ }^{173}$ The scientific evidence suggests that the South West of Western Australia is likely to continue to experience a drying trend. There is broad agreement among climate change models that the south-west faces a drier future. ${ }^{174}$

The Indian Ocean Climate Initiative has stated that:

$\mathrm{IOCI} 3$ modelling work indicates that as greenhouse gas concentrations continue to increase the large-scale changes to the atmosphere observed during the second half of the 20th century ... could continue during the 21st century... Decreases in rainfall are projected for SWWA in all months of the May to October half-year. In some months these reductions could exceed 20 millimetres. These reductions may be as large as, or larger than, those experienced at the end of the 20th century. ${ }^{175}$

Similarly, the Intergovernmental Panel on Climate Change concluded that 'based on multiple lines of evidence, annual average rainfall is projected to decrease with high confidence in south-western Australia. ${ }^{176}$

What are the implications of this dryer future for the groundwater resources of the South West? The CSIRO has conducted valuable research into this question, published in its 2009 Sustainable Yield reports and related peer-reviewed papers. As this research makes clear, reduced rainfall will have a significant impact on groundwater resources. As with surface water streamflow, there is an unfortunate 'multiplier effect' between rainfall and groundwater recharge. A 15-18 per cent drop in rainfall by 2030 (the projected 'dry scenario' reduction) would reduce recharge rates in the southwest's unconfined aquifer systems by 33-49 per cent. ${ }^{177}$ This means that while groundwater levels will continue to rise in some areas due to ongoing impacts from native vegetation clearance (e.g. the Dandaragan Plateau shown in Figure 12) there will be significant reductions in other areas. Yield declines may be greater than one third by 2030 in the Gnangara, Blackwood and Albany groundwater areas. ${ }^{178}$ Given that water demand in the South West is projected to increase by about 35 per cent to $2030^{179}$ this poses a significant challenge for water managers and the groundwater regulatory framework.

\footnotetext{
173 T.F. Stocker et al (eds), Climate Change 2013: The Physical Science Basis: Contribution of Working Group I to the Fifth Assessment Report of the Intergovernmental Panel on Climate Change (Cambridge University Press, 2013) 121, 91.

${ }^{174}$ CSIRO, above n 2, 3 ('Almost all global climate models (GCMs) used by the Intergovernmental Panel on Climate Change (IPCC) predict that SWWA will experience an even warmer and drier future'.)

175 Indian Ocean Climate Initiative, above n 140, 26

176 Intergovernmental Panel on Climate Change, above n 142, Chapter 25, 3.

${ }^{177}$ R. Ali et al, 'Potential climate change impacts on the water balance of regional unconfined aquifer systems in southwestern Australia' (2012) 16(12) Hydrology and Earth System Sciences 4581, 4581. This is relative to the historical period of 1975 to 2007.

${ }^{178}$ CSIRO, above n 2, iv.

179 Ibid.
} 
Figure 12: Projected change in groundwater levels in superficial aquifers of the southern Perth Basin between 2008 and 2030 (median future climate) ${ }^{180}$

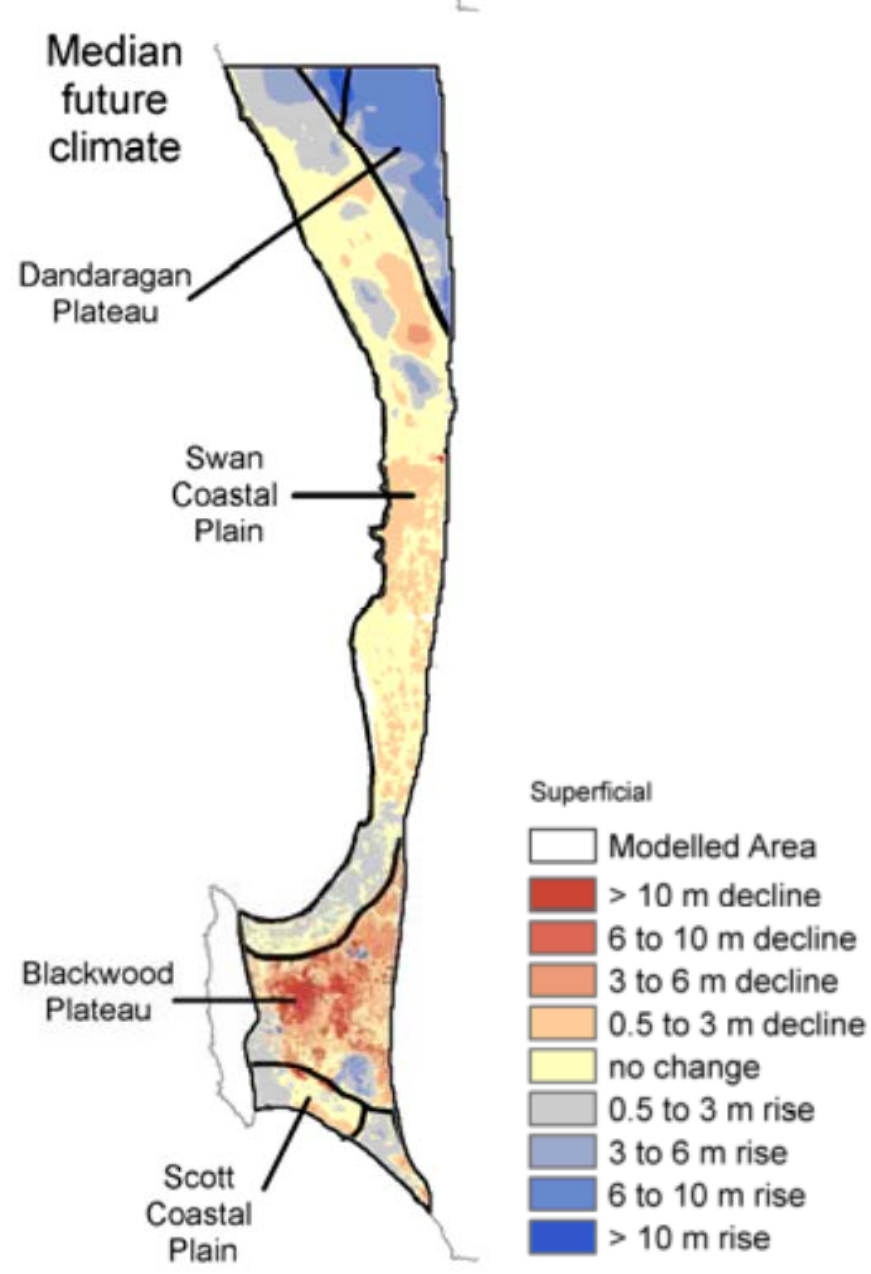

Reduced rainfall, and associated reductions in groundwater discharge to the ocean, will also increase the risk of seawater intrusion. In their study of the impacts of climate change on regional unconfined aquifer systems in the South West, Ali et al found that:

Groundwater discharge to the ocean under the dry future climate is expected to reduce by 27 percent in the Central Perth Basin and by 38 percent in the Southern Perth Basin. Instead of groundwater discharge, seawater intrusion is likely in the Peel-Harvey area under the dry future climate due to lower groundwater levels in coastal areas. Relatively large reductions in ocean discharge are expected under the median and dry future climates in the Central and Southern Perth basins due to lower groundwater levels, which increase the risk of seawater intrusion especially in conjunction with sea level rise projected due to climate change. ${ }^{181}$

Would effective action to constrain global greenhouse gas emissions moderate further drying in the South West? One study suggests that it would, because stabilisation of greenhouse gas concentrations would reverse the atmospheric circulation trend (i.e. contraction of westerly winds

\footnotetext{
180 Ibid 51.

${ }^{181}$ Ali et al, above n 177, 4595.
} 
towards the South Pole) causing reduced rainfall. ${ }^{182}$ However, even if effective international action is taken to stabilise greenhouse gas emissions over the coming decades it would take several centuries to fully reverse the drying trend. ${ }^{183}$ While not detracting from the need to reduce greenhouse gas emissions, this does highlight the importance of groundwater managers and groundwater regulation being able to respond to the challenges of a dryer South West climate.

182 Wenju Cai, Peter Whetton and David Karoly, 'The Response of the Antarctic Oscillation to Increasing and Stabilized Atmospheric CO2' (2003) 16 Journal of Climate 1525, 1536-1537.

183 Ibid. 


\section{Overview of regulatory issues and reforms}

In this Report we seek to address the following fundamental questions for groundwater management and regulation:

- How can groundwater use be maintained within sustainable limits in a drying climate, and how can groundwater be used productively and efficiently within these limits?

- What role does the regulatory framework for groundwater management have in achieving these goals?

This Report addresses these questions by examining the response by Western Australian groundwater managers to the drying South West, and the role of the regulatory framework in shaping this response. We consider, through a number of case studies, how the regulatory framework has coped with the 'stress test' of reduced rainfall since 1970, and whether other regulatory approaches could work better. ${ }^{184}$

Chapters 4, 5 and 6 focus on the question of how groundwater use can be maintained within sustainable limits in a drying climate:

- Chapter 4 deals with the risk that unlicensed groundwater uses, which are effectively outside the caps set by allocation limits, can expand to the detriment of other water uses or the environment. We consider the benefits of broader regulatory coverage of these unlicensed uses.

- Chapter 5 addresses the risks associated with setting allocation limits in a drying climate. We consider the benefits of a statutory water planning regime that mandates sustainable extraction limits and consideration of climate change. We also consider how water allocation plans should address environmental objectives in a drying climate, and the impact of other planning processes on groundwater management.

- Chapter 6 deals with the risks associated with a rigid water entitlements system, in which groundwater extraction cannot easily be adjusted to reflect the new reality of reduced rainfall and groundwater recharge. We consider the alternative of a 'share' entitlement system, under which a water user has a share in a variable consumptive pool rather than a fixed volumetric entitlement. We also consider the important issue of metering and monitoring to ensure that actual water use does not exceed authorised extraction.

Chapter 7 considers the issue of productive and efficient water use, and the shortcomings of the traditional approach of allocating groundwater resources for free to the first applicant. We consider

\footnotetext{
${ }^{184}$ In doing so we are taking up Sadler's invitation to see the South West as a laboratory for the study of climate change adaptation in practice: Sadler, above $n$ 1, 8.
} 
the role that market mechanisms, in particular, can play in promoting productive and efficient water use.

Chapter 8 deals with some of the implementation issues for the reforms outlined in chapters 4 to 7 as they apply to groundwater resources of the South West.

Readers familiar with national water policy and its implementation will appreciate that these are not new issues. Western Australia has in fact committed, through the Intergovernmental Agreement on a National Water Initiative, to many of the reforms we discuss, and many of the reforms have already been implemented in other Australian jurisdictions.

While Western Australia is lagging behind in implementing its commitments under the Intergovernmental Agreement, this does have a side benefit: we can consider and learn from the approaches in other jurisdictions. This is something that we seek to do in the following chapters of this report, while always applying the practical test: will the reform help us manage the South West's groundwater resources more effectively in a drying climate? This is, of course, not the only challenge faced by groundwater managers, but it is a major challenge in the South West of Western Australia and a useful lens through which to view the State Government's water law reform proposals. 


\section{Broader regulatory coverage}

\subsection{Unlicensed water use in a drying climate}

Unlicensed groundwater uses may increase relative to licenced use as they are not constrained by an allocation limit. This problem is exacerbated in a drying climate where there is less water available overall. Figure 13 illustrates this problem.

Figure 13: Unlicensed use crowds out licenced use in a drying climate

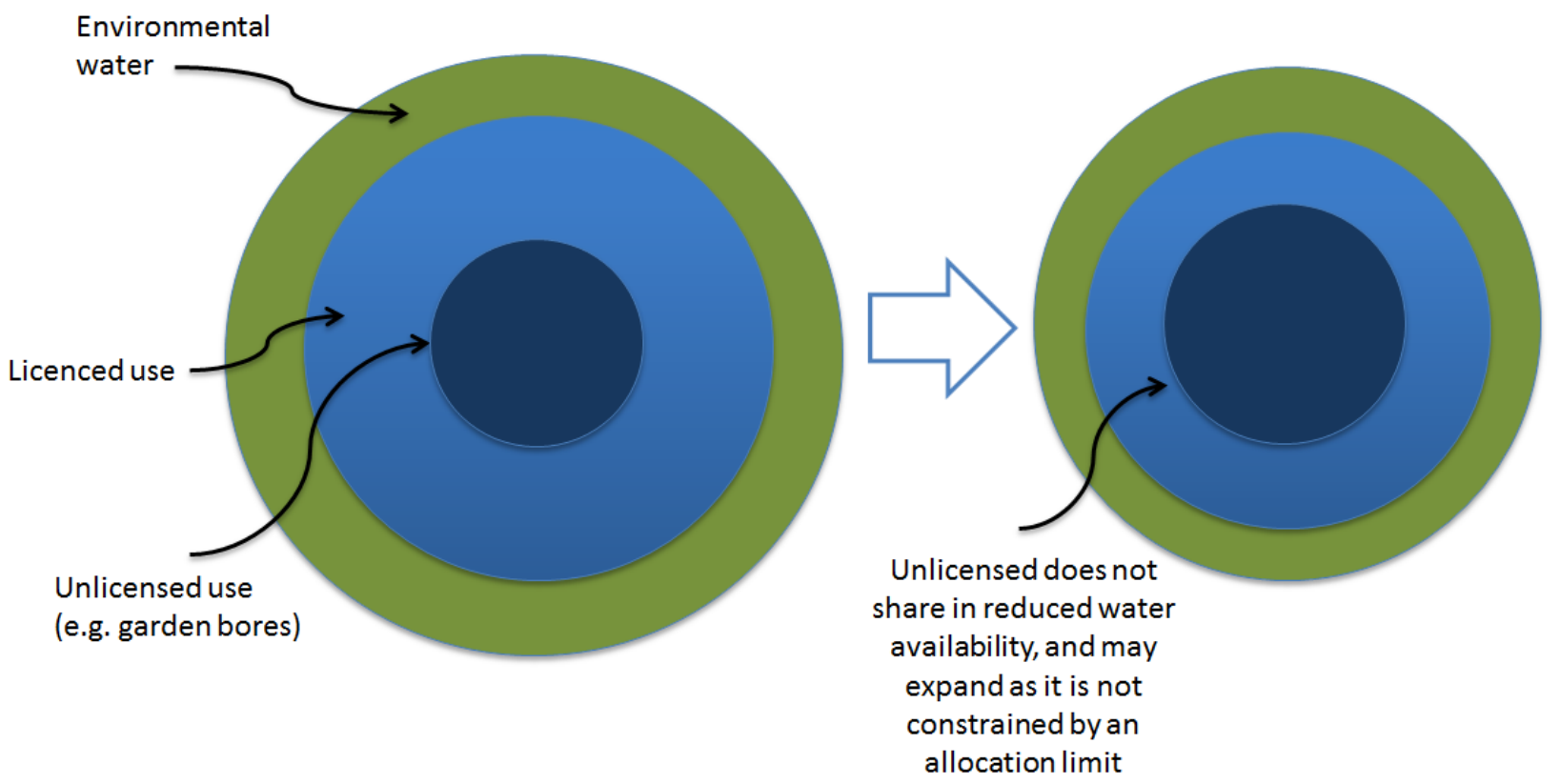

In principle, a groundwater regulatory framework should at least have the capacity to license all activities that, either individually or cumulatively, have a significant effect on the quantity of groundwater available for consumptive use or the environment.

The RIWI Act currently has a broad capacity to regulate the 'taking' of groundwater, but that capacity is not exercised in relation to stock and domestic use - to date, governments have exempted these uses from the licensing requirement because they have assessed the costs of licensing to outweigh the benefits. We consider in section 4.2 whether that position should be reconsidered in the context of the drying South West climate.

The RIWI Act, like most water resource management legislation in other Australian jurisdictions, does not currently have the capacity to regulate interceptions or extraction of water associated with changes in land use. The National Water Initiative has highlighted the need for reform in this area, noting that 'a number of land use change activities have potential to intercept significant volumes of surface and/or groundwater' and that 'if these activities are not subject to some form of planning and regulation, they present a risk to the future integrity of water access entitlements and the achievement of environmental objectives for water systems. ${ }^{185}$ In section 4.3 we consider whether new water resource management legislation should be able to licence water use by commercial

${ }^{185}$ Council of Australian Governments, above n 11, paras 55-56. 
plantations. We acknowledge that commercial plantations are not the only 'land use change' activity with the potential to affect groundwater systems. ${ }^{186}$

\subsection{Basic landholder rights - domestic garden bores}

Use of groundwater to water domestic gardens is a significant unlicensed use of water in the South West. For example, in 2009 there were an estimated 167000 domestic garden bores in the Perth metropolitan area, using approximately $73 \mathrm{GL}$ of water a year - about 15 per cent of all groundwater taken in the Perth region. ${ }^{187}$ As noted above, while basic water use efficiency standards have been established for watering domestic gardens there is no requirement to hold a licence to take that water (except in the unusual case in which a domestic bore is not taking water solely from the water table aquifer). ${ }^{188}$ This means that there are no limits on the number of garden bores or the total amount of water they use. As a result, garden bores in metropolitan areas have the potential to progressively reduce the amount of water available for other consumptive uses. This is illustrated by the base case scenario adopted in modelling for the Gnangara Sustainability Strategy, under which private licensed groundwater use was assumed to remain at 2007 levels but use by garden bores was assumed to increase by 3 per cent every year. ${ }^{189}$

Current State Government policy does not favour the licensing of domestic garden bores. It does, however, identify large areas of Perth that are unsuitable for such bores (Appendix G). The relevant policy document explains that areas may be unsuitable for a range of reasons, including impacts on local wetlands, the risks of exposing acid sulphate soils and cases in which 'the area is over-allocated to existing users, and further development of garden bores could present a sustainability risk to the groundwater'. ${ }^{190}$ No comprehensive regulatory requirements have been put in place to prevent the construction or use of garden bores in areas that have been designated as being unsuitable for that purpose. ${ }^{191}$

Clearly the administrative costs of licensing water use from a large number of garden bores are a substantial disincentive for regulation. Licensing on this scale is not unprecedented - the WA Fisheries Department, for example, has issued over 200,000 recreational fishing licences ${ }^{192}$ - but it is not common. Of other States and Territories, the Australian Capital Territory and South Australia (in the Padthaway and North Adelaide Plains Prescribed Wells Areas) license domestic groundwater use. ${ }^{193}$

\footnotetext{
${ }^{186} \mathrm{R}$ Benyon et al, 'Tree Water Use in Forestry Compared to Other Dry-Land Agricultural Crops in the Victorian Context: Report prepared for the Department of Primary Industries Victoria to Promote Scientific Knowledge in this Area ' (2007).

${ }^{187}$ Department of Water, above n 105, 3.

188 See above $n 61$.

189 J De Silva, 'PRAMS scenario modelling for the Gnangara Sustainability Strategy' (2009), 41

190 Department of Water, above n 105, 7.

${ }^{191}$ For example, standard subdivision conditions do not include a requirement to this effect: see Department of Planning and Western Australian Planning Commission, 'Model Subdivision Conditions Schedule' (2012). Abstraction of groundwater, including from garden bores, may be prohibited under the Contaminated Sites Act 2003 (WA) where groundwater is contaminated: see above n75. ${ }^{192}$ Department of Fisheries, 'Annual Report 2012-13' (Government of Western Australia, 2013) 8.

192 Department of Fisheries, 'Annual Report 2012-13' (Government of Western Australia, 2013) 8.

${ }^{193}$ Sinclair Knight Mertz, 'Assessment of groundwater licensing, metering and extraction estimation arrangements and techniques in Australia' (2012) 15, 19.
} 
One option would be to licence the taking of water from domestic bores in specified areas. This could be achieved under the current RIWI Act by replacing the current, blanket exemption for garden bores with a more limited exemption. ${ }^{194}$ The advantage of this approach from a groundwater management perspective is that existing bores in specified areas would be metered and regulated. The disadvantage would be the greater administrative costs for government and the costs to some bore owners of obtaining a licence and installing metering equipment.

Another option would be to prohibit the construction of new domestic bores in identified areas. Combined with watering restrictions for existing bores already in place under the Water Agencies (Powers) By-Laws 2010, this would provide a reasonable basis to manage future growth in abstraction in areas that are approaching or at full allocation. The prohibition could be imposed by by-laws made under the Water Agencies (Powers) Act 1984 (WA), ${ }^{195}$ or under the new water resource management legislation, if it is drafted in a way that would allow this. For ease of enforcement, it would be appropriate for any offence provision to apply to drillers of bores as well as the relevant landholder.

\section{Law Reform Recommendation: Domestic Garden Bores}

Consideration should be given to two options:

- to license new and existing domestic garden bores in specified areas; or

- to prohibit the construction of new domestic garden bores in specified areas.

\subsection{Commercial plantations}

Commercial plantations are another example of unlicensed uses that can have a substantial impact on groundwater resources. This can occur through two mechanisms: first, reduction in recharge to the watertable through interception; and secondly, use by the trees within the unsaturated soil zone and extraction of groundwater from the beneath the water table. ${ }^{196}$ In most jurisdictions in Australia, including Western Australia, a commercial plantation does not need a water licence.

\section{Case Study: Pine plantations on the Gnangara Mound, Western Australia ${ }^{197}$}

As noted above, the Gnangara Mound is a superficial aquifer in and around the north of Perth. There are 22000 hectares of pine plantations overlying the Gnangara Mound. Planting of pines commenced in 1918, but it was not until the early 1940s, and particularly since the 1960s, that extensive plantations were established. The plantations are located on State Forest No. 65 and

\footnotetext{
${ }^{194}$ See footnote 55 above on the current exemption.

195 Such a prohibition could be established through by-laws made under s 34(3)(fa) of the Water Agencies (Powers) Act 1984 (WA) which empowers the making of by-laws to 'prohibit, impose restrictions on or otherwise regulate the use of water'.

${ }^{196}$ Sinclair Knight Mertz, CSIRO and Bureau of Rural Sciences, 'Surface and/or Groundwater Interception Activities: Initial Estimates' (2010) 59; Department of Water, 'Plantation Forestry and Water Management Guideline' (2009) 9; P Polglase and R Benyon, 'The impacts of plantations and native forests on water security: Review and scientific assessment of regional issues and research needs' (2009) 5.

${ }^{197}$ Material for this case study is drawn from EPA Bulletin 273; De Silva, above $n$ 189; Gnangara Coordinating Committee, 'Gnangara Sustainability Strategy: Draft for Public Comment' (Government of Western Australia, 2009); Western Australian Planning Commission and Water and Rivers Commission, 'Gnangara Land Use and Water Management Strategy: Final Report' (2001); Forest Products Act 2000 (WA); Department of Water, above n 196.
} 
managed by the Forest Products Commission, a statutory body with functions that include the management of plantations and the sale of forest products.

Pine plantations have a significant effect on recharge. Maturing pine plantations effectively stop all recharge and, where the water table is within about $10 \mathrm{~m}$, there is the likelihood that the pines are net extractors of water. Studies by the Department suggest that pine plantations have made a significant contribution to water level decline on two hydrogeological provinces of the Gnangara Mound (table 4).

Table 4: Factors affecting watertable decline on the Gnangara Mound

\begin{tabular}{|c|c|c|}
\hline \multirow{2}{*}{$\begin{array}{l}\text { Study and factor affecting } \\
\text { decline }\end{array}$} & \multicolumn{2}{|c|}{ Watertable decline (m) } \\
\hline & Leederville Window & Kardinya Shale \\
\hline \multicolumn{3}{|l|}{ Yesertner 2007 (1979-2004) } \\
\hline Climate & 3.0 & 0.0 \\
\hline Abstraction & 1.5 & 1.0 \\
\hline Pine plantation & 1.5 & 2.0 \\
\hline \multicolumn{3}{|l|}{ Da Silva (1979-2008) } \\
\hline Climate & 3.0 & 0.0 \\
\hline Abstraction & 2.0 & 1.5 \\
\hline Pine plantation & 2.0 & 2.0 \\
\hline
\end{tabular}

The pine plantations' water use is not regulated under the RIWI Act. The Department of Water will take into account the effect of pine plantations on recharge in setting water allocation limits and the amount of water available for licenced use. It will also provide advice to other bodies with planning or management responsibilities concerning plantations. However, water use by plantations is not itself licenced.

By 2001 it was agreed that the Gnangara pine plantations would be progressively removed from the Mound. This could be done by the State Government through the Forest Products Commission, as the plantations are in State Forest and are managed by the Commission, which is subject to government-endorsed management plans and Ministerial direction. However, the rate at which removal of pines can be achieved is affected by state agreements to provide a set supply of timber, delivered over a period of up to 25 years, from 2003 from Gnangara and surrounding areas.

Modelling carried out for Gnangara Sustainability Strategy suggests that under a 'base case' scenario (gradual removal of pines to 2031) storage will decline by another 500GL before it starts to recover, while under the 'immediate pine removal' scenario decline is only another $230 \mathrm{GL}$. This makes clear that the rate at which the pines are removed will have a major impact on efforts to stabilise groundwater decline on the Gnangara Mound. The Draft Gnangara Sustainability Strategy recommends that 'opportunities for the accelerated removal of pine plantations be investigated within the economics of existing commercial agreements' (p.x). However, a complicating factor is the importance of the pine plantation as a source of food for the endangered Carnaby's Cockatoo. 
There are a number of lessons that can be drawn from this case study. One basic lesson is that plantations can have significant impacts on groundwater resources. The case study also points to the risk of governments entering into commercial agreements, and parliaments endorsing commercial agreements, that lock in these groundwater impacts over a long period - particularly in the face of a drying climate and increased water scarcity. Finally, the case study illustrates the lack of control water managers have over unlicensed uses of groundwater.

It does need to be recognised that the Gnangara Mound is an unusual, if not unique, example in the South West of a large commercial plantation being located over a shallow, over-allocated aquifer. The substantial impact on groundwater levels experienced in the Gnangara Mound should not be seen as representative of plantation impacts generally. Plantations make up around 3 per cent of the total land area of the South West ${ }^{198}$ and it is rare for a plantation to cover a significant proportion of a water management area. ${ }^{199}$ It is also important to appreciate that plantations have benefits in addressing stream and dryland salinity in some parts of the South West. ${ }^{200}$

Nevertheless, there is a question as to whether the new water management legislation should provide the capacity to regulate water use from plantations in specified areas. This would allow plantations to be brought within the water licensing system in areas where they are likely to have a significant effect on other water users, groundwater-dependent ecosystems or the groundwater resource. The risk of this occurring may increase over time in a drying South West, for three reasons: first, groundwater scarcity will increase the significance of all unlicensed uses; secondly, under dryer conditions plantations will have increased water requirements; ${ }^{201}$ and thirdly, more plantations may be developed in response to climate change mitigation measures that encourage carbon sequestration. ${ }^{202}$

South Australia's Natural Resource Management Act 1994, as recently amended, provides an example of how water resource management legislation can provide the capacity to bring commercial plantations within the water licensing system. The following case study describes how this legislation has been used to regulate plantations on South Australia's Lower Limestone Coast.

\section{Case study: Commercial plantations on the Lower Limestone Coast Prescribed Wells Area,} South Australia ${ }^{203}$

The Lower Limestone Coast Prescribed Wells Area (LLC PWA) is located in the South East of South Australia. There is significant plantation forestry in the region, representing about $10 \%$ of the total land area of the LLC PWA and a greater proportion of mid to southern areas. Softwood plantations (mainly pine) cover approximately 104,000 hectares and hardwood plantations (mainly blue gums) cover approximately 40,500 hectares.

\footnotetext{
${ }^{198}$ CSIRO, above n 2, 33.

199 Department of Water, above n 196 (maps at Appendices 1-5). Note that this document was published in 2009.

200 Ibid 5, 8.

${ }^{201}$ Sinclair Knight Mertz, CSIRO and Bureau of Rural Sciences, above n 195, 61.

202 National Water Commission, 'Water Policy and Climate Change in Australia' (National Water Commission, 2012) 3233,62 .

${ }^{203}$ Material for this case study is drawn from the Natural Resource Management Act 2004 (SA), the Lower Limestone Coast Prescribed Wells Area Water Allocation Plan, and discussions and email correspondence with Christina Shepherd, Principal Policy Officer, South Australian Department of Environment, Water and Natural Resources.
} 
Water level declines in the LLC PWA have been attributed to the combined effect of underground water extraction, reduced rainfall and the effects of land use change - including the rapid expansion of commercial forests in the area in the late 1990s and early 2000s. In recognition of the impact of commercial forests, it is proposed that commercial forestry in the area will be licensed.

The legislative basis for this licensing is provided by amendments to the Natural Resource Management Act 2004 (SA) that came into effect on 4 October 2013. Under these provisions water allocation plans may identify commercial forests as being appropriate to bring within a licensing regime and principles and methodologies by which to determine the hydrological impact of those forests: s 76(9). The Minister may then, following consultation with the Minister responsible for forests, formally designate the areas in question as 'declared forestry areas'. Once this has been done forest managers must ensure that the commercial forests they manage are the subject of a forest water licence: s169B.

An important first step in this process has already been taken. The Water Allocation Plan for the Lower Limestone Coast Prescribed Wells Area (November 2013) identified all commercial forests within the LLC PWA as being appropriate to bring within the licensing regime. The Plan provides that water allocations associated with forest water licences should be quantified based on an assessment of recharge interception and direct groundwater extraction (where applicable). Because it is not economically practical to measure actual forest water consumption, the Plan adopts deemed values based on scientific research conducted with the industry. For example, where the forest overlies a water table that is less than six metres, direct groundwater extraction is deemed to be $1.82 \mathrm{ML} / \mathrm{ha} /$ year for hardwoods and $1.66 \mathrm{ML} / \mathrm{ha} / \mathrm{year}$ for softwoods. Deemed values are also adopted for hardwood and softwood plantation interception of recharge according to years since planting and thinning. Based on these deemed values, there are estimated annual volumes of the commercial forestry impacts (water use) on the groundwater resources of the various management areas; in other words, the basis for water allocations.

A forestry area has not yet been declared by the Minister under the Natural Resource Management Act 2004 (SA). The regulations and other administrative arrangements that need to be in place to initiate and administer forest water licensing on an ongoing basis are also yet to be established. The Department and the South East Natural Resource Management Board anticipate that the necessary regulatory and administrative arrangements will be in place in 2014-15. Once a forestry area is declared, all existing commercial forestry operators will be eligible to apply for a forest water licence that has a water allocation attached that reflects the hydrological impact of the existing forest. Under the forest licensing system, new commercial forest development proposals will be subject to assessment under LLC WAP policy and will be required to purchase water allocations on the water market, as no water remains available for allocation under the Plan.

In areas where over-allocation issues have been identified, the LLC WAP proposes that forest water licensing be used to reduce the impact of commercial forestry by reducing the water allocated to forestry (as well as to other water licence holders) over time. However, it should be noted that, under the Natural Resource Management Act 2004 (SA), water allocated to forestry may only be reduced after harvesting has occurred, i.e. the water allocations on forest water licences will not be able to be reduced in a manner that would require forest operators to 
prematurely clear-fell their forests (s169E). Variations of water allocations must be consistent with the relevant water allocation plan, but no compensation is payable for reductions in water allocations.

The South Australian reforms only came into effect in October 2013, so it is difficult to assess their usefulness in practice. Even so, the broad framework provided by these laws - the licensing of commercial plantations in designated areas, with the hydrological impact of those plantations being assessed in accordance with rules in the relevant statutory water allocation plan - appears to offer a workable approach. ${ }^{204}$

The 2013 Position Paper and an earlier Departmental guideline on plantations suggest that the new water resource legislation is likely to provide the capacity to bring plantations within the water licensing system. ${ }^{205}$ The 2013 Position Paper indicates that one possible approach would be to '[set] a threshold where regulating interceptions by plantations for a specific water resource would only be triggered where scientifically robust analysis has identified the risks and benefits of plantations to the water resource, other water users or the environment. ${ }^{206}$ For the reasons given above, we would endorse this approach.

\section{Law Reform Recommendation: Plantations}

Western Australia's new water resource management legislation should recognise commercial plantations as a consumptive use of groundwater resources and have the capacity to licence water use by commercial plantations in specified areas identified by the statutory planning process.

\section{Better groundwater planning}

\subsection{Statutory water plans and sustainable extraction limits}

Good water allocation planning is central to maintaining groundwater use within sustainable limits in a drying climate. It is through this planning that allocation limits are identified. There are two important elements of good water allocation planning in this context. The first is that plans be statutory, in the sense of being made in accordance with statutory requirements, and that they have a binding legal effect. This provides a consistent, legally secure basis to set allocation limits and make administrative decisions consistent with those limits. ${ }^{207}$ Secondly, the requirements in the water resource management legislation concerning the contents of water allocation plans must provide a sound basis to set and achieve sustainable allocation limits.

As we have seen, Western Australia's water allocation plans are currently non-statutory, in the sense that they are not made in accordance with the requirements in Part III of the RIWI Act including the requirement to consult the (non-existent) Water Resources Council. The State Government has indicated that this requirement would be removed in the new water resource management legislation, which should remove any obstacles to the making of statutory water

\footnotetext{
${ }^{204}$ We have not had the opportunity to closely consider, and do not comment on, the detailed design of the South Australian plantations regime.

${ }^{205}$ Department of Water, above n 70, 29; Department of Water, above n 196, 5.

${ }^{206}$ Department of Water, above n 70, 29.

${ }^{207}$ Gardner, Bartlett and Gray, above n 22, 292-3.
} 
allocation plans in the future. ${ }^{208}$ However, the State Government clearly intends that there will be a gradual transition to statutory plans. The 2013 Position Paper suggests that this will only occur where

- water resources are approaching or have approached full allocation;

- the water resource is extensive, both in area and in the volume of water available for consumption;

- the science of the resource is sufficiently understood, including historical recharge and usage data;

- there are a relatively large number of users competing for access to the resource; and

- the benefits of establishing a consumptive pool and the supporting systems (including statutory water allocation plans) clearly outweigh the costs. ${ }^{209}$

What about the contents of the new statutory water allocation plans? In its discussion of the new plans, the State Government states that 'we need to make sure the amount of water we are drawing on is sustainable', but does not indicate how the new legislation will address this question. ${ }^{210}$ We suggest that the new legislation should require a scoping document to be issued, as part of the process of preparing a plan, to detail how sustainable yields will be identified. ${ }^{211}$ These scoping documents could address issues such as the assessment of recharge and its role in determining sustainable yield, and the use of numerical groundwater models. ${ }^{212}$ Where the provisions of the final plan differ from the sustainable yield determined in accordance with the scoping document an explanation would have to be provided for that discrepancy. ${ }^{213}$

An alternative, stronger approach would be to provide that the allocation limit must be consistent with the sustainable yield. This approach is relatively unusual in water management legislation, but was adopted in the Water Act 2007 (Cth) for the Murray-Darling Basin. That Act requires allocation limits to be consistent with an 'environmentally sustainable level of take'. This term is defined in the Act. ${ }^{214}$ Foerster examined the influence of the 'environmentally sustainable level of take' requirement on the development of the Basin Plan. Her conclusion was that while the final diversion limits involved a trade-off between different policy objectives and between the interests of

\footnotetext{
${ }^{208}$ Department of Water, above n 70, 18.

209 Ibid 18.

210 Ibid 7.

${ }^{211}$ The current proposal is that the Minister to publish a 'notice of intent to publish a plan': Department of Water, above n 70, 19.

${ }^{212}$ On the role of recharge, see Ali et al, above $\mathrm{n} 176,4582$ ('a reliable estimate of recharge is the first requirement in estimating the impact of climate change on groundwater systems'); New South Wales, State Water Management Outcomes Plan Order 2002 Part II, Division 1, Target 1e (providing that provide that in the absence of a detailed assessment of a groundwater source the sustainable yield is to be ' 100 percent of average annual recharge for a groundwater source where there is no significant ecosystem dependency' and '70 percent of average annual recharge where there is significant ecosystem dependency').

${ }^{213}$ Compare the current approach described in section 1.3 above.

${ }^{214}$ The Water Act 2007 (Cth), s 4 defines "environmentally sustainable level of take" as ...the level at which water can be taken from that water resource which, if exceeded, would compromise:(a) key environmental assets of the water resource; or (b) key ecosystem functions of the water resource; or (c) the productive base of the water resource; or (d) key environmental outcomes for the water resource."
} 
Basin States, they represent a more environmentally sustainable level of trade-off that would have been likely under legislation with weaker parameters. ${ }^{215}$

On balance, we favour the former approach because there may be rare cases in which the Minister should be able to approve an allocation limit that is clearly not sustainable, such as where there is a substantial, pre-existing use that the Minister believes should be able to continue for the life of the project. It would be better to allow for this, and ensure that the unsustainable use is transparently identified with a view to phasing it out in the longer term, rather than to discourage a government from making a statutory water plan for the area.

There are two other points we would make about statutory water plans. The first is that given the significance of these plans, including their influence on the volume of water available to entitlement-holders, there is a good argument that they should be disallowable instruments. This appears to be proposed in Western Australia. The State Government has indicated that that the new water allocation plans will 'have the force of law and be subject to parliamentary scrutiny'. ${ }^{216}$ This suggests that the new Act will require that the plans will, like regulations, be tabled and subject to parliamentary disallowance. ${ }^{217}$

Finally, it is important that statutory plans be supported by effective monitoring and reporting arrangements, in order to ensure that there is transparency as to whether allocation limits are being achieved.

\section{Law Reform Recommendation: Statutory water allocation plans}

The legislation should:

- provide for statutory water allocation plans that bind decision-makers performing functions under the legislation and other government agencies exercising powers under other legislation

- require, as part of the process for preparing each statutory water allocation plan, the publication of a scoping document that details how sustainable yields will be assessed

- require plans to identify the sustainable yield of each groundwater resource, explain how the sustainable yield was calculated and explain any discrepancy between the sustainable yield and the provisions of the plan

- provide that plans must be approved by the Cabinet (Governor in Council) and then tabled in Parliament and subject to disallowance

- specify the monitoring that is to be carried out to assess whether the objectives of plans are being achieved, and requirements for the reporting of that information.

\subsection{A duty to consider and address risks from climate change}

The potential impacts of climate change on South West rainfall have been discussed since at least 1987, when the CSIRO produced national climate change scenarios and participated in the conference 'Greenhouse: Planning for Climate Change'. ${ }^{218}$ In a paper to that conference entitled

\footnotetext{
${ }^{215}$ Anita Foerster, 'The Murray-Darling Basin Plan 2012: An Environmentally Sustainable Level of Trade-off?' (2013) 16(1) Australasian Journal of Natural Resources Law and Policy 41.

${ }^{216}$ Department of Water, above n 70, 19.

217 Interpretation Act 1984 (WA) s42.

${ }^{218}$ Sadler, above n 1, 2.
} 
'The water resource implications of a drying climate in South West Western Australia' Sadler, Mauger and Stokes stated that:

Current predictions of the greenhouse-induced changes in this region derive essentially from the expected polewards movements of the atmospheric high pressure belt from the desert latitudes. As a result the winter depression and cold fronts, which bring rain to the South West, will pass further south. ${ }^{219}$

While acknowledging that the magnitude and timing of the expected shift to rainfall was uncertain, Sadler et al put forward a working scenario of a reduction of $20 \%$ in average annual rainfall between 1970 and 2040 (Figure 14). The rate of rainfall decline has, to date, been greater than predicted in 1987 (Figure 15).

Figure 14: CSIRO scenario for decline in Perth rainfall due to climate change (1987) ${ }^{220}$

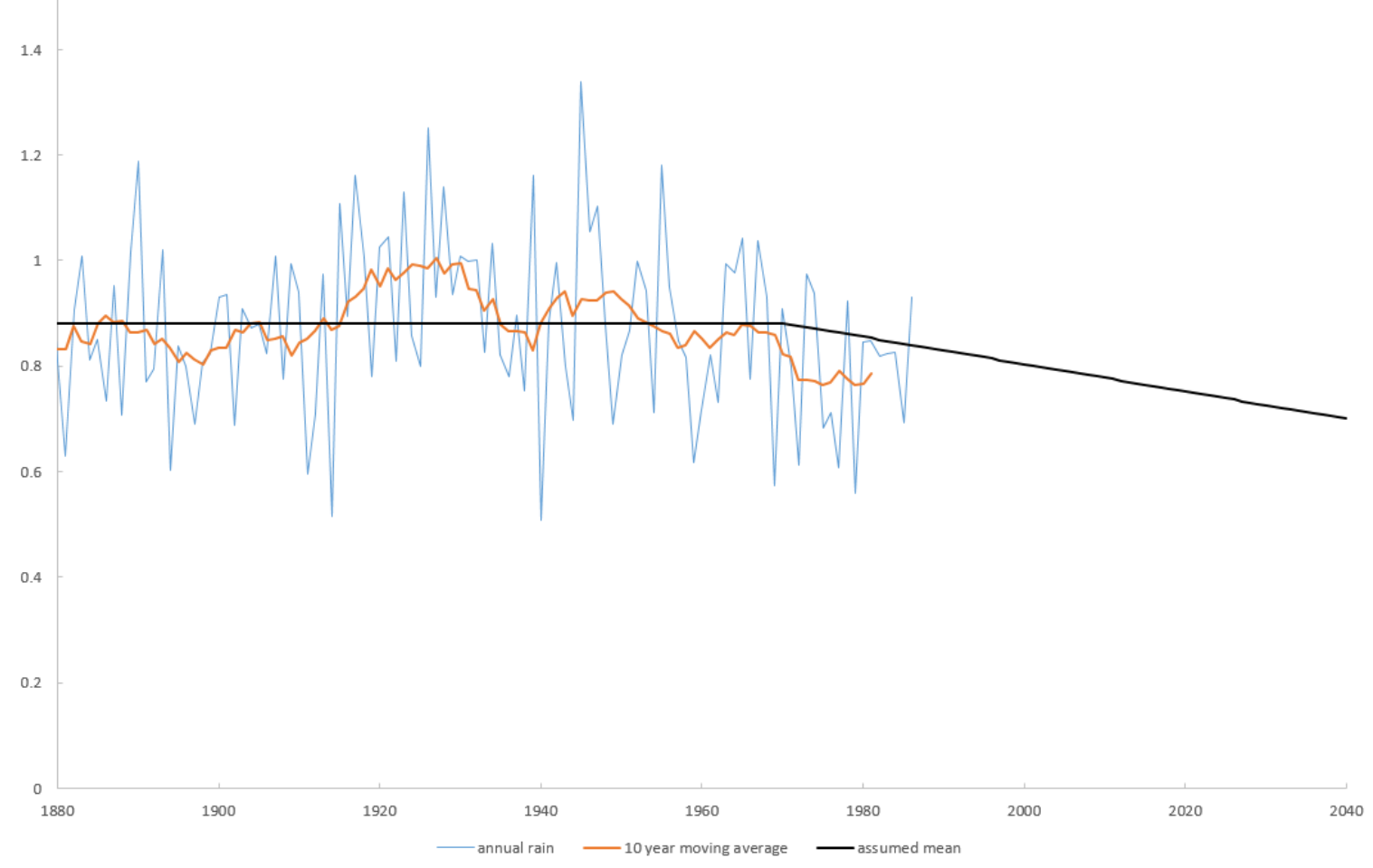

\footnotetext{
${ }^{219}$ The paper was published as B S Sadler, G W Mauger and Stokes R A, 'The water resource implications of a drying climate in south-west Western Australia' in G I Pearman (ed), Greenhouse: Planning for Climate Change (CSIRO Publishing, 1988)

${ }^{220}$ Reproduced from Ibid 299.
} 
Figure 15: CSIRO scenario compared to actual rainfall 221

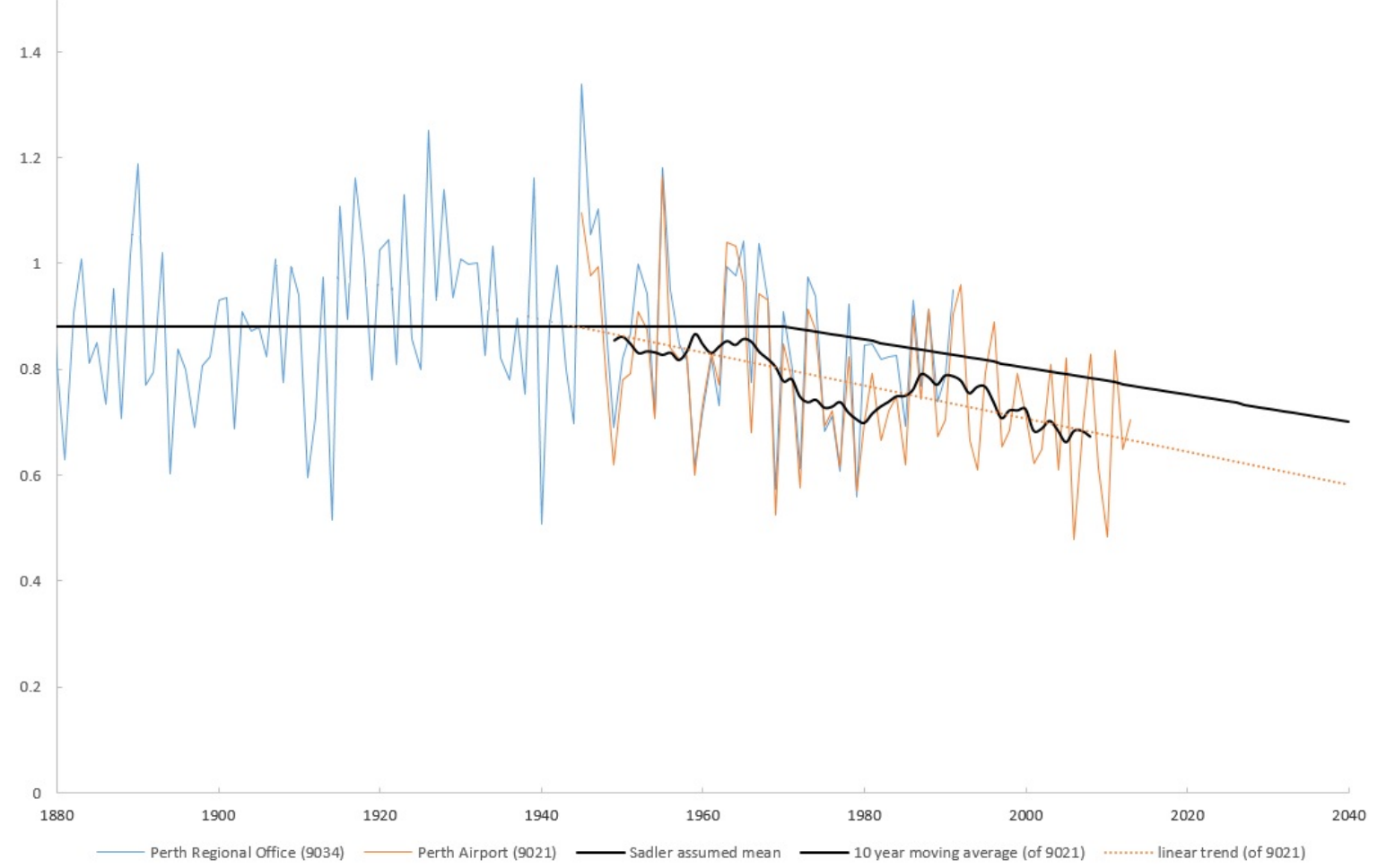

As we have seen, these predictions of climate change were taken into account by water supply planners as early as the 1980 s (e.g. in timing of source development). Perhaps because the impact of the reduced rainfall on recharge was not as immediately obvious as the impact on streamflow, ${ }^{222}$ it took longer for the drying climate to be taken into account in setting groundwater allocation limits. For example, the Gingin Interim Allocation Strategy (2002) noted climate change as a future risk, but made clear that '[f]or the purpose of his strategy, climate change and its impact on recharge have not been taken into account'. ${ }^{223}$ However, every allocation plan since 2007 has taken climate change into account in some way, at least through the selection of relatively recent rainfall averages as a basis for estimating future rainfall. One finalised plan and one draft plan also use climate change projections (Appendix E). ${ }^{224}$

The significance of rainfall assumptions can be illustrated by considering allocation limits on the Gnangara Mound, one of the South West's largest and most heavily allocated groundwater resources. The Department used a 'base case' of 1976-2004 rainfall (788mm/yr) in setting

\footnotetext{
${ }^{221}$ Note that the Perth Regional Office weather station (9034) closed in 1992, so we have not been able to extend the original rainfall. We have instead used the full set of data from nearby Perth airport. The orange line is the trend line through that data.

222 McFarlane et al, above n 165, 325 (making the following observation in relation to the Gnangara system: 'The impact of climate change on recharge was also significant but was not so obvious. Because aquifers were full where water tables were at the ground surface in wetlands, any reduction in rainfall was initially offset by reductions in evapotranspiration and surface drainage. It was only when water tables fell over summer, to an extent that winter recharge was not sufficient to fully replace the losses, that the reduced rainfall was reflected in lower net recharge and a decline in groundwater levels.')

${ }^{223}$ Water and Rivers Commission, 'Managing the Water Resources of the Gingin Groundwater Area, WA: Interim SubRegional Allocation Strategy' (2002) 19.

${ }^{224}$ See also National Water Commission, 'National Water Planning Report Card 2011' (2011) 355.
} 
allocation limits in 2009. ${ }^{225}$ However, it also modelled the impact of what it called a 'very dry climate' scenario using 1996-2004 rainfall $(696 \mathrm{~mm} / \mathrm{yr}){ }^{226}$ This scenario showed substantial additional declines in groundwater storage to 2014 (450-500GL) on top of the base case declines $(\sim 400 G L) .{ }^{227}$ As it has turned out, average rainfall since that modelling was carried out has been below even the 'very dry climate' scenario. ${ }^{228}$ The Department indicated, in its 2013 evaluation of the Gnangara Allocation Plan, that it is now using the dryer 2001-10 rainfall period for Gnangara groundwater modelling, which involves a reduction of approximately 10 per cent in average annual rainfall compared to the 1974-2004 period. ${ }^{229}$ It also indicated that '[i]n subareas where there are declining water levels and there is limited to no demand, the water available for licensing (the general component of the allocation limit) has been reduced by $10 \%$ consistent with reduced rainfall and recharge. ${ }^{230}$

There is a clear need, acknowledged by the Department of Water, for a more consistent approach to the use of climate change projections in groundwater (and surface water) allocation planning. To that end, the Department has developed a Geographic Information System tool that is capable of producing a time-series of future climate for any part of the State at a gridded resolution of $5 \mathrm{~km}$ $x 5 \mathrm{~km}$. The 'future climate' includes information on rainfall, but also temperature, radiation, relative humidity, evapotranspiration and evaporation. This tool will be used, in accordance with guidelines currently being developed, in developing water allocation plans. The tool and guidelines are intended to ensure a more consistent approach to baseline periods, scenarios and timeframes for projections, as well more consistent use of climate models.

While there is a need for greater consistency in the use of climate scenarios, the Department has retained an appreciation of the uncertainties associated with climate projections and their impacts on water resources. This is consistent with Bates' observation that a traditional 'prediction paradigm' may be less effective than a planning approach that considers a range of scenarios, informed by the latest climate science, and identifies associated decision points and management responses. ${ }^{231}$ This 'multiple scenarios' approach has implications for the regulatory system, which needs to have the capacity not only to support effective planning, but also to implement management responses such as reductions in authorised abstraction. As we shall see, there is room for the Western Australian regulatory framework to be improved in these areas.

In the light of the above discussion, we endorse the proposal in the 2013 Position Paper that statutory water allocation plans will 'describe the effects or potential effects of climate variability or change on the water resources and identify the policy programmes that are included in the plan for

\footnotetext{
${ }^{225}$ Department of Water, 'Gnangara Groundwater Areas Allocation Plan: Statement of Response' (2009) 6 ('We used a medium-term, dry climate (1976-2004) for the PRAMS modelling that supported our allocation limit decisions for the Superficial aquifer.')

${ }^{226}$ VIJ Vogwill et al, 'PRAMS Scenario Modelling for Water Management of the Gnangara Groundwater Mound' (2008). ${ }^{227}$ Ibid 56-58.

${ }^{228}$ e.g. On Perth Airport rainfall measurements, average rainfall from 2009 to 2013 was 657.7mm/yr (average of 615.8mm (2009), 483.4mm (2010), 835.8mm (2011), 649.4mm (2012), 704.0mm (2013)). Statistics sourced from Bureau of Meteorology, Monthly Rainfall: Perth Metro (7 April 2014)

$<$ http://www.bom.gov.au>.

${ }^{229}$ Department of Water, 'Gnangara Groundwater Areas Allocation Plan: Evaluation Statement 2009-2011' (2013) 21.

230 Ibid 23.

${ }^{231}$ Bryson C Bates et al, 'Incorporating climate change in water allocation planning' (2010) 16.
} 
managing these effects'. ${ }^{232}$ We go further to suggest that, given the importance of climate change for management of water resources in Western Australia, there should be a requirement in the new Act for the Minister to ensure that water allocation plans consider and deal with climate change impacts. The Water Act 2007 (Cth), discussed below, provides a possible model.

\section{Case Study: Statutory guidance on water planning and climate change}

It is common for water resource management legislation to identify the matters that should be addressed in water plans. While it is by no means common for such legislation to include reference to climate change, examples do exist.

\section{Murray-Darling Basin, Australia}

The Water Act 2007 (Cth) states that the Basin Plan must include 'an identification of the risks to the condition, or continued availability, of the Basin water resources' ${ }^{233}$ and that:

The risks dealt with must include the risks to the availability of Basin water resources that arise from the following:

(a) the taking and use of water (including through interception activities);

(b) the effects of climate change;

(c) changes to land use;

(d) the limitations on the state of knowledge on the basis of which estimates about matters relating to Basin water resources are made.

$(\text { emphasis added })^{234}$

'Water resource' is defined broadly to include 'all aspects of the water resource (including water, organisms and other components and ecosystems that contribute to the physical state and environmental value of the water resource). ${ }^{235}$

The Act also provides that the Basin Plan must include 'the strategies to be adopted to manage, or address' these risks. ${ }^{236}$

\section{Victoria, Australia}

The Climate Change Act 2010 (Vic) prescribes a range of statutory planning functions for which climate change must be taken into account, including decisions made under the Catchment and

\footnotetext{
${ }^{232}$ Department of Water, above n 70, 19.

${ }^{233}$ Water Act 2007 (Cth) s 22.

234 Ibid

235 Ibid s4.

236 Ibid
} 
Land Protection Act 1994 (Vic) and Water Act 1989 (Vic).

Ontario, Canada

Ontario's Clean Water Act and associated regulations take a slightly different approach, providing that assessment reports must include 'A summary, based on readily accessible information, of how conclusions in the assessment report are likely to be affected by changes to the climate of the source protection area in the 25 years following preparation of the report. ${ }^{237}$

\section{Law Reform Recommendation: Duty to address climate change in making statutory water} allocation plans

The legislation should require the Minister to consider climate change risks in the preparation of statutory water allocation plans and to address those risks in the plan provisions.

\subsection{Sharing groundwater with the environment in a drying climate}

This chapter has focussed, to date, on what water resource management legislation should say about the nature and content of water allocation plans. In this section we will go a step further to consider what these plans themselves should say about environmental water allocations in a drying climate.

As a number of commentators have noted, climate change is relevant to the environmental objectives set by water allocation plans. The National Water Commission has made the point that:

Future adaptation responses may involve making difficult 'triage' decisions in managing water-dependent ecosystems. They may include decisions about whether to continue to water already degraded sites that are unlikely to survive due to climate change. ${ }^{238}$

The reverse proposition is also true: that difficult triage decisions may need to be made to reduce or remove consumptive use in order to sustain important environmental assets under pressure from climate change, such as Ramsar-listed wetlands or areas containing threatened species or ecological communities.

Underlying these decisions is a fundamental question: how should a declining water resource be shared between environmental and consumptive use in a drying climate? Western Australia's experience with managing groundwater-dependent ecosystems on the Gnangara Mound provides a case study that may help us answer these questions.

\footnotetext{
${ }^{237}$ Clean Water Act SO 2006 s 15(2)(i); Ontario Regulations 298/07 r 13(1) (item 7).

${ }^{238}$ National Water Commission, above n 202, iv.
} 


\section{Case Study: Environmental objectives and their implementation on the Gnangara Mound, Western Australia ${ }^{239}$}

The Gnangara Mound is a superficial aquifer in and to the north of Perth. Recharge is by annual rainfall. Discharge is primarily from evapotranspiration, but also partly from outflow to oceans and rivers and leakage to underlying aquifers. The amount of groundwater which can be extracted from the Mound is mainly determined by the desire to limit impact on the environment, particularly the wetlands of the area.

In 1987 the Environmental Protection Authority (EPA) assessed a proposal by the Water Authority (which was at that time both the public water utility and the water regulator) to abstract groundwater from the Gnangara Mound for public water supply. By this time streamflow to dams had already declined substantially (see Figure 6 above) and new water sources were needed for Perth's expanding population.

A central issue considered by the EPA was how the social and ecological values of wetlands could be protected. To this end, the EPA recommended 'preferred minimum water levels' and 'minimum water levels' for specified wetlands. These levels were based on an assumption that a $0.5 \mathrm{~m}$ change in water level should be the limit for the most environmentally sensitive areas. The EPA acknowledged that, given the complexity of wetlands and the factors affecting them, setting limits in this way was 'somewhat arbitrary and non-scientific', but suggested that it be used as an interim approach.

The EPA noted in its 1987 report that 'there is mounting, but not universally accepted evidence, that the burning of fossil fuels and the release of carbon dioxide into the atmosphere will produce a warming of the Earth's climate in the decades ahead' and that the effects predicted for the South West included lower rainfall and associated impacts on wetlands. It did not, however, suggest that this be taken into account in determining water level criteria, suggesting instead that it may be appropriate to measure water levels against 'recent historic low water levels'.

In response to the EPA's advice, the Minister approved the proposal subject to conditions that incorporated water level criteria for wetlands. Other monitoring sites for groundwater-dependent vegetation were subsequently added to the Ministerial conditions, each with minimum water level requirements.

There were increasing levels of non-compliance with water level requirements from the mid-1990s (Figure 16). Non-compliance with Ministerial Conditions is a serious offence (under the current Act a 'Tier 1' offence) but enforcement action was not taken. This may in part have been because the proponent was a government agency, but that fact that reduced rainfall was a major cause of reduced water levels is likely to have also been a contributing factor.

\footnotetext{
${ }^{239}$ Material for this case study is drawn from Ministerial Statements 21, 437, 438, 687, 819; EPA Bulletins 273, 1115, 1324; triennial compliance reports submitted to the Environmental Protection Authority; Gnangara Coordinating Committee, above n 169; and Department of Water, 'Environmental Management of Groundwater Abstraction from the Gnangara Mound: Triennial compliance report to the Office of the Environmental Protection Authority: Jul 2009 - June 2012' (2013).
} 


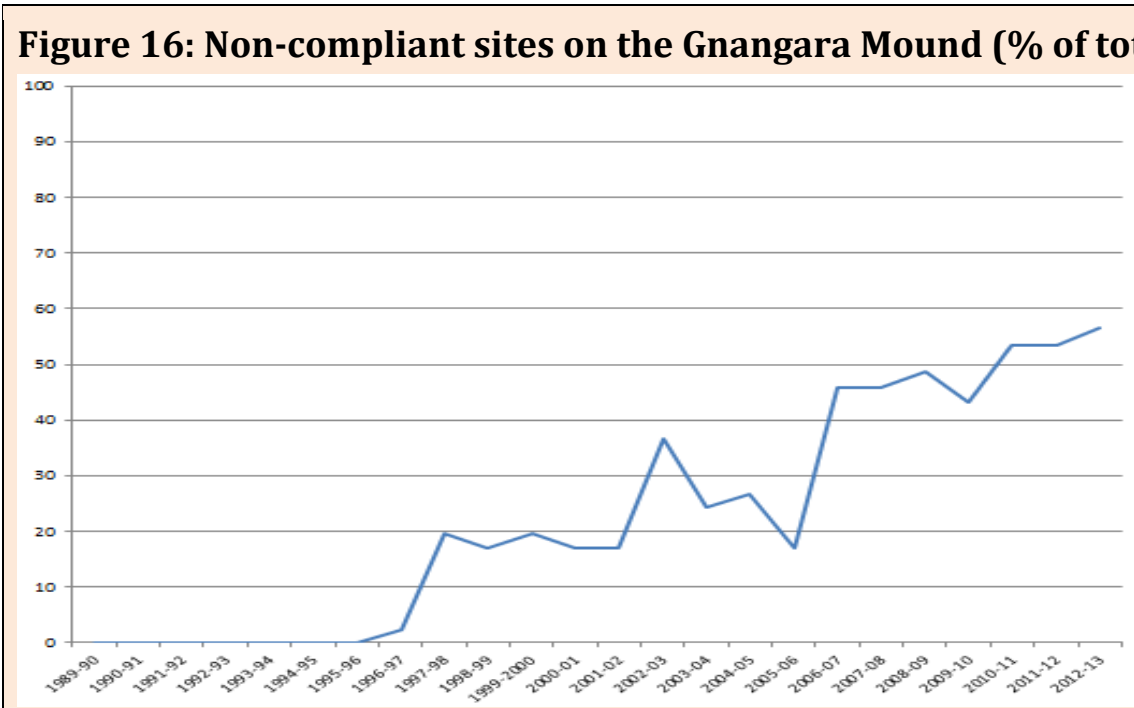

In 2009, the EPA accepted that seven sites should be removed from the Ministerial Conditions because they had lost their original environmental values or were predominantly affected by climate and land use rather than abstraction. This advice was accepted by the Minister, and was formalised in a new set of Ministerial conditions published in December 2009.

The draft Gnangara Sustainability Strategy ('draft strategy') was also released for public comment in 2009. The draft strategy was an interagency initiative that considered future land use and abstraction options in the light of climate change scenarios. The draft strategy and associated reports included projections of future water levels on the Gnangara superficial aquifer under different climate, land use and abstraction scenarios.

One of the key questions addressed in the GSS was how environmental objectives should be set in a drying climate. It characterised this task as follows:

Any management approach to the environment supported by the system needs to start with the fundamental question of what environment are we likely to have in 2030 ? That is, what groundwater-dependent ecosystems will be maintained in the context of a drying climate and the continued decline of groundwater levels in the Gnangara system? This question reflects the dominance of a drying climate on any land use and water management actions that may be taken.

The draft strategy found that '[s]etting Ministerial conditions based on groundwater levels recorded in a wetter period of time has resulted in breaches that could not be averted by any water and land management practice' (p28) and that 'conditions based on setting fixed water level criteria are no longer appropriate under current climate conditions' (vii).

The draft strategy identified 45 wetlands as significant in terms of biodiversity values and ecological function, and recommended the following management measures for those areas:

- An 'adaptive management approach to the monitoring of the environmental impacts of water decline' be developed, including a separation of the role of climate, public abstraction and private abstraction; long-term monitoring of indicator species to detect ecosystem change; and frequent review of management actions.

- Development of 'local area models and risk assessments to identify wetlands and other 
groundwater-dependent ecosystems most at risk from declining water levels'.

- 'Where wetlands are predicted to dry out despite land and water management interventions, management should centre on transition to a terrestrial ecosystem'.

- 'Opportunities to augment groundwater levels using recycled water, either directly or in the vicinity of high value ecosystems, be investigated.'

- 'Blocks of remnant bushland be protected from clearing, further fragmentation and multiple threats (fire, dieback, feral animals, weed invasion and groundwater level decline) to strengthen the ecological resilience of the system and that these blocks and existing conservation reserves be complemented by a series of regional ecological linkages.'

The draft strategy also recommended reductions in abstraction for public water supply, private licensed abstraction and unlicensed abstraction.

There do not appear to be any plans to finalise the draft strategy. However, it remains an important document and source of recommendations for the future management of the Gnangara Mound.

This case study emphasises the importance of taking climate change scenarios into account in framing environmental objectives - particularly where those objectives become part of legally requirements that may last for several decades. Perhaps understandably, given the state of climate science in 1987, a drying scenario was not considered by the EPA in its advice on minimum water level requirements. The result was 'regulatory lines in the sand' which implicitly assumed a stable climate and which proved hard to change when a drying trend was detected. ${ }^{240}$

While environmental objectives expressed as fixed 'regulatory lines in the sand' may not always work in a drying climate, they do have their benefit of clarity and measurability - you know when they have been breached. One study undertaken by the National Water Commission suggests that despite their flaws water level criteria on the Gnangara Mound did have a number of benefits:

The original trigger levels, although relatively simple, undoubtedly resulted in greater conservation of GDEs [groundwater-dependent ecosystems] than would have occurred in their absence. The breaches of criteria levels became an important driver for improving the understanding of GDE dependence, and scientific investigations have been used to inform revisions to the Ministerial conditions. ${ }^{241}$

This gives rise to a dilemma. Fixed environmental objectives, such as water level criteria for wetlands, may not be appropriate in a drying climate but more amorphous 'adaptive management' approaches may not give the environment the protection it needs. American academic Robin Kundis Craig considers this issue in her analysis of principles for climate change adaptation law. ${ }^{242}$ She concludes that there does need to be flexibility in environmental management goals where there are changing baseline conditions due to climate change, but this should be 'principled flexibility'. She defines 'principled flexibility' as meaning that:

\footnotetext{
${ }^{240}$ McFarlane et al, above n 165, 328.

${ }^{241}$ Sinclair Knight Mertz, above n 131, 7.

${ }^{242}$ Robin Kundis Craig, "Stationarity is Dead' - Long Live Transformation: Five Principles for Climate Change Adaptation Law' (2010) 34 Harvard Environmental Law Review 9.
} 
both the law and regulators (1) distinguish in legally significant ways uncontrollable climate change impacts from controllable anthropogenic impacts on species, resources, and ecosystems that can and should be actively managed and regulated, and (2) implement consistent principles for an overall climate change adaptation strategy, even though the application of those principles in particular locations in response to specific climate change impacts will necessarily encompass a broad and creative range of adaptation decisions and actions. ${ }^{243}$

Craig goes on to argue that one of the principles for an overall climate change adaptation strategy should be improvement of resilience and adaptive capacity, rather than traditional legal objectives of preservation and restoration. ${ }^{244}$

We would add to this analysis that in a water allocation planning context, 'principled flexibility' could continue to involve the use of regulatory requirements such as minimum water level requirements, as long as these requirements are regularly reviewed through the plan review process. This would have the benefit of ensuring that if any 'triage' decisions are made to abandon environmental assets this is at least done in a considered way, with the benefit of community consultation.

Keeping these points in mind, we return now to the first question we posed earlier: how should a declining water resource be shared between environmental and consumptive use in a drying climate? We suggest that this question cannot be answered by a mathematical formula, such as a rule that reductions should be shared equally between environmental and consumptive uses. Rather, it should be determined by a planning process, undertaken with the benefit of community consultation, that:

- identifies environmental objectives in the context of climate change scenarios;

- sets out management measures that will be adopted to achieve those objectives; and

- involves regular reviews and adjustments in light of new information.

In a number of respects the draft Gnangara Sustainability Strategy provides a model of good groundwater planning in a climate change context. While there is no doubt room for debate on the detail, the strategy at least explores the consequences of future climate change and how it should be addressed. It deals with the difficult question of how to manage water sustainably in a drying climate by proposing management measures, including land use management measures to strengthen ecological resilience and reductions in public and private water allocations. It is a useful model for water planners in areas likely to be affected by a drying climate to consider.

\subsection{Sharing groundwater between consumptive uses in a drying climate}

Water allocation plans can also have a role in deciding how groundwater, and groundwater scarcity, should be shared between consumptive uses in a drying climate. To date, the main technique for doing so has been the 'reservation' of a specified volume of water, through nonstatutory allocation plans, for public water supply. Groundwater shortages in Perth's rapidly developing North West corridor have prompted a debate on whether this practice should be extended to other water uses, such as watering public open space.

\footnotetext{
243 Ibid 17-18.

244 Ibid 18, 39.
} 


\section{Case Study: Water for Public Open Space in Perth's North West Corridor}

Allocation of groundwater for public open space in new urban developments has emerged as a major issue in Perth. This case study focuses on this issue in Perth's North West Corridor, a 9000 hectare coastal strip development stretching from Quinns Rocks (around 40km from Perth's central business district) to Yanchep (around 60km from the central business district). We focus in particular on allocation for urban development in the coastal suburb of Alkimos, a few kilometres north of Quinns Rocks.

The North West Corridor has been earmarked for urban development for decades. The report Planning Structure for the North-West Corridor (1977) estimated that the 1971 population of 2,300 people would ultimately increase to 333,000 and identified areas for future urban development, commercial use and parks and recreation. ${ }^{245}$ This plan, and subsequent revisions, provided the basis for amendments to the Metropolitan Region Scheme and the City of Wanneroo's planning scheme that zoned land for urban development.

The 1977 Structure Plan, and later structure plans, acknowledge the importance of groundwater for public water supply, but do not address groundwater demands for public open space. This is despite the fact that substantial quantities of water can be used to establish and maintain streetscapes, passive open space and particularly grassed ovals. Land developers are required as a condition of subdivision to set aside $10 \%$ of the development area for public open space, ${ }^{246}$ and are typically responsible for maintaining these areas for two years before they are handed over to local government for ongoing management. ${ }^{247}$

For water allocation planning purposes the superficial aquifer in the North West Corridor is broken up into three subareas: the Quinns, Eglington and Yanchep subareas. The Gnangara Groundwater Allocation Plan (2009) contained the following allocation limits for these subareas (Table 5). ${ }^{248}$

Table 5: North West Corridor Allocation Limits and Licenced Use (2009)

\begin{tabular}{||l|l|l|l|l|}
\hline Subarea & $\begin{array}{l}\text { Allocation limit* } \\
\text { (GL/yr) }\end{array}$ & $\begin{array}{l}\text { Licenced } \\
\text { entitlement } \\
\text { (GL/yr) }\end{array}$ & $\begin{array}{l}\text { Public water } \\
\text { supply } \\
\text { (reserved) }\end{array}$ & Water available \\
\hline Quinns & 24.65 & 16.46 & Yes & Limited \\
\hline Yanchep & 10.87 & 2.73 & Yes & Limited \\
\hline Eglinton & 15.45 & 2.47 & Yes & Limited \\
\hline
\end{tabular}

It gradually became clear that the 'limited' available water identified in the Gnangara Allocation

${ }_{245}$ Metropolitan Region Planning Authority, 'Planning Structure for the North West Corridor' (1977).

${ }^{246}$ Planning and Development Act 2005 (WA) ss143, 152; Department of Planning and Western Australian Planning Commission, above n 191; Western Australian Planning Commission, 'Policy No. DC 2.3 - Public Open Space in Residential Areas' (Undated).

${ }^{247}$ In practice licences to take groundwater for this purpose are either granted for a 2 year period, or granted for a longer period but transferred to the relevant local government. The authors examined the public records of 33 licences granted in the Eglington subarea. Of the 16 licences held by land developers, 10 licences were for 2 year terms, 5 licences were for 2 year terms and 4 licences were for 10 year terms. Department of Water, Water Register

<http://www.water.wa.gov.au/ags/WaterRegister/>, (30 April 2014).

${ }^{248}$ Department of Water, above $\mathrm{n} 39,42$. Unlicensed use is not separately itemised in the plan, but the plan indicates that allocation limits take into account of estimates of unlicensed use: Ibid, 39. 
Plan would be insufficient for proposed public open space in the North West Corridor, including Alkimos (which is located in the Eglinton subarea). In 2010 the State Government acknowledged that finding water sources for irrigation of public open spaces was becoming 'increasingly problematic' due to 'increased demand ... and a reduction in their availability due to the drying climate'. ${ }^{249}$ It noted that this was a particular problem in the north-west corridor for future urban areas such as Alkimos, given that 'the majority of the water resource is allocated for future public supply'. ${ }^{250}$ It suggested that 'alternative sources for irrigation of open spaces, such as recycled water, will need to be considered in future development'. ${ }^{251}$

In or about 2011, the Department of Water advised that there was insufficient groundwater available in Alkimos for irrigation of all proposed public open space, given that most of the otherwise available groundwater was reserved for use in providing potable public water supply. ${ }^{252}$ In the light of this groundwater shortage, a group of local landowners developed an alternative proposal that would have involved the Water Corporation providing non-potable water to irrigate both public open space residential properties. This water would initially be sourced from groundwater supplies (presumably drawing from the amount reserved for public water supply in the Gnangara Allocation Plan), but could ultimately use treated wastewater from the nearby Alkimos Waste Water Treatment Plant. ${ }^{253}$ The proposal failed when the aspect related to watering public open space was rejected by the City of Wanneroo. The City plainly preferred that it be able to access groundwater directly without paying for it, rather paying the Water Corporation at the proposed rate, which was equivalent to $75 \%$ of the cost of potable water. ${ }^{254}$ The City also noted that there was no guarantee that treated wastewater would be used as a water source. ${ }^{255}$ In light of the failure of this proposal, developers in Alkimos proceeded with licence applications, in the hope of obtaining a licence before the Eglinton subarea became fully allocated, and a number were successful in doing so. ${ }^{256}$

From the middle of 2012, the Department of Water, in cooperation with the City of Wanneroo, started work on a strategy to deal with the issue of groundwater and public open space in the North West Corridor. In essence, the aim of the strategy was to 'set a volume of water that individual developers will be able to access from the Quinns, Eglinton and Yanchep groundwater subareas to meet all essential POS requirements'. ${ }^{257}$

The first step in developing the strategy was to review the total volume of water available in each subarea. This unfortunately revealed that the allocation limits were too high. While new allocation limits have not yet been published, the Department has indicated that the review of allocation limits showed that 'significantly less water was available in the Quinns and Eglinton subareas'. ${ }^{258}$

\footnotetext{
${ }^{249}$ Department of Planning and Western Australian Planning Commission, 'Directions 2031 and Beyond: Metropolitan Planning Beyond the Horizon' (2010) 65.

250 Ibid.

251 Ibid.

${ }^{252}$ City of Wanneroo, 'Council Agenda: Ordinary Council Meeting, 15 November 2011' (2011) 17.

253 Ibid.

254 Ibid.

255 Ibid.

${ }^{256}$ Department of Water, Water Register (Eglinton subarea, 16 May 2014).

${ }^{257}$ Department of Water, 'North West Corridor Water Supply Strategy' (2014) 1.

258 Ibid.
} 
The second step in the strategy was to identify how much water was needed to 'provide essential public parkland at maximum efficiency'. ${ }^{259}$ This involved setting new design criteria as to the percentage of different types of public open space that could be irrigated (Table 6), and applying a reduced irrigation rate of $6,750 \mathrm{kl} / \mathrm{yr} / \mathrm{ha}$ (down from the previous $7,500 \mathrm{kl} / \mathrm{yr} / \mathrm{ha}$ ). The new design criteria, in particular, greatly reduced the amount of water that could be applied to public open space. $^{260}$

Table 6: Design criteria for public open space in the Northern Corridor

\begin{tabular}{|l|l|l|}
\hline Type of POS & Description & \% of site that is irrigated \\
\hline \multirow{3}{*}{ Active } & Regional/district playing fields & $64 \%$ \\
\cline { 2 - 3 } & Neighbourhood playing fields & $59 \%$ \\
\hline Passive & Pocket parks & $33 \%$ \\
\cline { 2 - 3 } & Schools & $30 \%$ \\
\cline { 2 - 3 } & Streetscapes/Entry statements & Establishment only \\
\hline
\end{tabular}

The third step in the strategy was to calculate a total volume of water available for each developer based on the new design criteria and irrigation rate. These volumes were recorded in a nonstatutory document known as North Coastal Growth Corridor Licensing Schedule ('Licensing Schedule'). After some allowance for other small volume uses (e.g. licences for passive areas associated with hospitals and universities) the balance of the available water in each subarea will be reserved for public water supply. ${ }^{261}$

The North West Corridor Water Supply Strategy, describing measures outlined above, was published in January $2014 .{ }^{262}$ In the same month, the Department sent letters to land developers in the North West Corridor with existing licences, indicating an intention to adjust the licensee's volumetric entitlement so that it aligns with the amount identified in the Licensing Schedule. This involves a substantial reduction in volumetric entitlements for ongoing irrigation of public open space. $^{263}$

There have been some implementation difficulties with the North West Corridor Water Supply Strategy. ${ }^{264}$ Nevertheless, the strategy is a laudable attempt to deal with a difficult question: how to

\footnotetext{
259 Ibid.

${ }^{260}$ Interview by Alex Gardner and Michael Bennett with Debra Goostrey and Peter Bowyer, Urban Development Institute of Australia (WA) (Perth, 22 April 2014); Interview by Michael Bennett with land developer (Perth, 14 May 2014). It was suggested to the authors that the impact of these new requirements on land developers was exacerbated by the City of Wanneroo setting rigid and very low budgets for public open space facilities, making it more difficult to establish nonirrigated areas with recreational value, such as basketball courts or barbeque facilities: Ibid.

${ }^{261}$ Department of Water, above $\mathrm{n} 257$.

262 Ibid.

263 Interview by Michael Bennett with land developer (Perth, 14 May 2014).

${ }^{264}$ It was suggested to the authors that the impact of these new requirements on land developers was exacerbated by three factors: (1) The strict implementation, at least initially, of a City of Wanneroo policy which set rigid and very low value caps for public open space facilities, making it more difficult to establish non-irrigated areas with recreational value, such as basketball courts or barbeque facilities; (2) Proposed water licence amendments having no regard to the public open space that had already been developed, meaning that in some cases there was no water allocation for the proposed public open space areas in the balance of the development; (3) Changes to the planning approvals system which meant that developers could not proceed to settlement on sold lots without having completed the public open
} 
share groundwater between competing consumptive uses in a drying climate. This involved setting new priorities, by effectively reserving groundwater for public open space and reducing reservations for public drinking water supplies. At the same time, new efficiency requirements were imposed on the use of groundwater for public open space in order to ensure that all land developers in the corridor could access groundwater, and to maximise the residue left for drinking water supplies.

The Economic Regulation Authority has argued against the practice of reserving groundwater even for public water supply, on the basis that the Department 'may inadvertently reserve a water resource that has a higher value alternative use'. ${ }^{265}$ However, the reservation of water for specified uses does provide the capacity to make sure water is available, on an equitable basis, for water uses that provide a public benefit. ${ }^{266}$ There is a strong argument that the provision of water public open space, with its substantial recreational and health benefits, falls into that category. We recommend that the new water resource management legislation should at least keep open the option of reserving water through statutory water allocation plans.

\section{Law reform recommendation: Reservation of groundwater}

The new water resource management legislation should provide that statutory water allocation plans may reserve water for specified purposes.

\section{Flexilble water entitlements}

\subsection{The need for flexibility in a drying climate}

There is a greater risk, in a drying climate, that groundwater resources will become over-allocated. This over-allocation is recognised when allocation limits are lowered to reflect the realities of reduced groundwater recharge (Figure 17). As we have seen, this has occurred in the South West where a number of groundwater resources have become over-allocated. ${ }^{267}$

space: Interview by Alex Gardner and Michael Bennett with Debra Goostrey and Peter Bowyer, Urban Development Institute of Australia (WA) (Perth, 22 April 2014); Interview by Michael Bennett with land developer (Perth, 14 May 2014 ). ${ }^{265}$ Economic Regulation Authority, 'Final Report Inquiry on Competition in the Water and Wastewater Services Sector' (2008) 28.

${ }^{266}$ A more difficult question is whether water could be reserved for private uses, such as to ensure that water is available in for horticulture in areas zoned for that purpose. There have been a number of State Administrative Tribunal cases that illustrate the dilemma of landowners who cannot obtain groundwater to carry out horticultural activities, but have difficulty in obtaining the planning approvals needed to make other use of the land: Strawbridge \& Anor and Western Australian Planning Commission [2006] WASAT 96; Maher \& Anor and Western Australian Planning Commission [2006] WASAT 129; Bojanich and Western Australian Planning Commission [2006] WASAT 315; Waddell v Western Australian Planning Commission [2007] WASAT 82.

267 See n 172 above. 


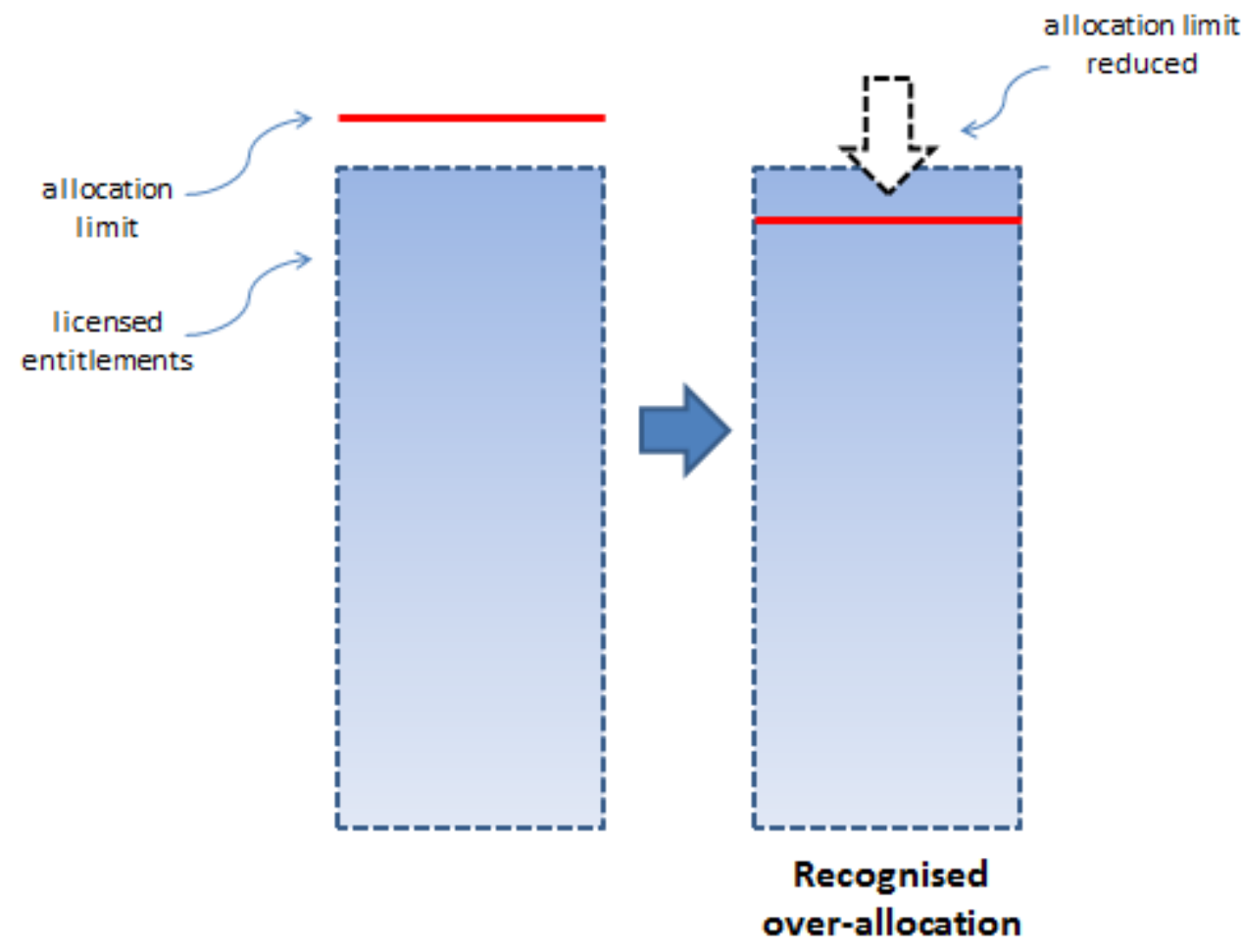

This raises the question of what legal mechanisms are available to address over-allocation. We consider below the mechanisms that are currently available under the RIWI Act and how they have been used in South West groundwater areas, before turning to consider an alternative entitlements system.

\subsection{Problems with the existing entitlements system}

\section{Variation of volumetric entitlements: current regulatory options}

As discussed in Chapter 1, the practice in Western Australia is for groundwater licences to specify a maximum volume of water that may be taken under that licence each year. There are a number of regulatory options available to reduce this amount in order to address over-allocation. The allocation specified in the licence may be varied by licence amendment, or licences may be renewed with a reduced amount specified on the licence. Directions may also be issued by the Minister (or delegate) to reduce the amount of water that may be taken. Key features of these regulatory mechanisms are summarised in the following table.

Table 7: Existing regulatory mechanisms to address over-allocation

\begin{tabular}{|l|l|l|l|}
\hline \multicolumn{2}{|c|}{ Wechanism } & When it may be used & Compensation issues \\
\hline $\begin{array}{l}\text { Ministerial direction } \\
\text { (temporary } \\
\text { reductions) }\end{array}$ & $\begin{array}{l}\text { Where the quantity of } \\
\text { water in a water } \\
\text { resource is, or is likely to } \\
\text { be, insufficient to meet } \\
\text { demand, including any } \\
\text { demand made by the }\end{array}$ & No compensation. & $\begin{array}{l}\text { Direction must be } \\
\text { served in writing on the } \\
\text { persons in question. } \\
\text { Persons subject to } \\
\text { direction may apply to } \\
\text { State Administrative }\end{array}$ \\
\hline
\end{tabular}




\begin{tabular}{|c|c|c|c|}
\hline & $\begin{array}{l}\text { needs of the } \\
\text { environment; or where a } \\
\text { water shortage } \\
\text { declaration has been } \\
\text { published in the } \\
\text { Government Gazette. }^{268}\end{array}$ & & $\begin{array}{l}\text { Tribunal to review the } \\
\text { direction. }{ }^{269}\end{array}$ \\
\hline $\begin{array}{l}\text { Licence amendment: } \\
\text { general }\end{array}$ & $\begin{array}{l}\text { To protect the water } \\
\text { resource or associated } \\
\text { environment from } \\
\text { unacceptable damage, } \\
\text { or to prevent a serious } \\
\text { inconsistency arising } \\
\text { with an approved } \\
\text { plan. }\end{array}$ & $\begin{array}{l}\text { Compensation may be } \\
\text { available, but broad } \\
\text { exceptions apply. }{ }^{271}\end{array}$ & $\begin{array}{l}\text { Minister (or delegate) } \\
\text { must consult licensee } \\
\text { before amending } \\
\text { licence. }{ }^{272} \text { Licensee } \\
\text { may apply for } \\
\text { compensation. } \\
\text { Licensee may apply to } \\
\text { State Administrative } \\
\text { Tribunal to review a } \\
\text { decision to amend the } \\
\text { licence or refuse } \\
\text { compensation. }{ }^{274}\end{array}$ \\
\hline $\begin{array}{l}\text { Licence amendment: } \\
\text { 'use it or lose it' }\end{array}$ & $\begin{array}{l}\text { Where the quantity of } \\
\text { water that may be taken } \\
\text { under the licence has } \\
\text { consistently not been } \\
\text { taken. }{ }^{275}\end{array}$ & No compensation. ${ }^{276}$ & $\begin{array}{l}\text { Minister (or delegate) } \\
\text { must consult licensee } \\
\text { before amending } \\
\text { licence. }{ }^{277} \text { Applicant } \\
\text { may apply to State } \\
\text { Administrative Tribunal } \\
\text { to review the } \\
\text { decision. }{ }^{278}\end{array}$ \\
\hline $\begin{array}{l}\text { Licence renewal with } \\
\text { reduced entitlement }\end{array}$ & $\begin{array}{l}\text { On expiry of previous } \\
\text { licence. }\end{array}$ & No compensation. & $\begin{array}{l}\text { Applicant may apply to } \\
\text { State Administrative } \\
\text { Tribunal to review the } \\
\text { decision. }{ }^{279}\end{array}$ \\
\hline
\end{tabular}

\footnotetext{
${ }^{268}$ Rights in Water and Irrigation Act 1914 (WA) s 26GD.

${ }^{269}$ Rights in Water and Irrigation Act 1914 (WA) s 26GH(1).

${ }^{270}$ Ibid sch 1, cl 34.

${ }^{271}$ Above pp 11-12.

${ }^{272}$ Rights in Water and Irrigation Act 1914 (WA), sch 1, item 26.

${ }^{273}$ Rights in Water and Irrigation Act 1914 (WA), sch 1, item 39.

${ }^{274}$ Rights in Water and Irrigation Act 1914 (WA), ss 26GG(1)(e), 26GH(2).

${ }^{275}$ Rights in Water and Irrigation Act 1914 (WA), sch 1, cl 24(2)(d).

${ }^{276}$ See discussion of compensation provisions in section 1.3 above.

${ }^{277}$ Rights in Water and Irrigation Act 1914 (WA), sch 1, cl 26.

${ }^{278}$ Rights in Water and Irrigation Act 1914 (WA), sch 1, cl 39.

${ }^{279}$ Rights in Water and Irrigation Act 1914 (WA), s 26GG(1)(c).
} 


\section{Use of regulatory options in practice}

\section{Use of licence amendments and directions to address over-allocation}

As we have seen, there is a significant problem with groundwater over-allocation in the South West. Western Australia has committed, as part of the National Water Initiative, to identify and achieve 'firm pathways' to address over-allocation. ${ }^{280}$ However, as the following case studies illustrate, there has only been limited use of licence amendment powers to address over-allocation.

Rather than using licence amendments to address over-allocation, the following strategy can be seen in some allocation plans adopted since the Department's formation in 2007:

- where the Department assessed that falling groundwater levels were due to current abstraction being out of balance with a changing climate, it reduced allocation limits to below the level of current entitlements ${ }^{281}$

- in those areas classified as over-allocated no new licences were issued, limiting the risk of the over-allocation problem getting worse ${ }^{282}$

- efforts to reduce over-allocation focused on improved efficiency, increased compliance activity and recouping of unused entitlements ${ }^{283}$

- in some cases the Water Corporation's entitlements were reduced on renewal of its licences, but with considerable flexibility to allow increased allocations in dry years. ${ }^{284}$

The directions power has not been used to address over-allocation. A notice was published in 2002 declaring a water shortage for the South West, ${ }^{285}$ but has not been used as a basis to issue Ministerial directions to address over-allocation. ${ }^{286}$

\section{Case study: Over-allocation in the Collie groundwater area}

The proclaimed Collie groundwater area covers what is known as the 'Collie Coal Basin'. The major groundwater uses in the Basin are dewatering associated with open cut coal mining and use of groundwater for cooling purposes in three coal-fired power stations. Coal mine dewatering, in particular, has had significant impacts on groundwater levels, with levels declining by up to $50 \mathrm{~m}$

\footnotetext{
${ }^{280}$ Council of Australian Governments, above n 9, cl 25(v).

${ }^{281}$ e.g. Department of Water, 'Gnangara Groundwater Areas Allocation Plan' (Department of Water, 2009) xii, 3, 9-10, $25,44,66$.

282 e.g. Ibid 66.

283 e.g. Ibid.

${ }^{284}$ As we see below, the Upper Collie Water Allocation Plan also flags reducing private allocations on licence renewal, but this has not yet occurred in practice.

${ }^{285}$ Water and Rivers Commission, 'Rights in Water and Irrigation (Water Shortage-Southwest) Order 2002' in Western Australia, Government Gazette No 48, 19 March 2002 1343, 1346.

${ }^{286}$ Pers comm Mick Owens, Department of Water, 21 November 2013.
} 
compared to its pre-mining state in some areas. ${ }^{287}$

The Collie Coal Basin has two distinct areas, the Cardiff and the Premier, separated by the Stockton Ridge formation. ${ }^{288}$ Groundwater in the Premier area is the most heavily over-allocated, mainly due to allocations for mine dewatering. The Upper Collie Water Allocation Plan (2009) indicated that the Premier-Lower Collie resource has an allocation limit of 2.2GL/yr and mine dewatering entitlements of $49 \mathrm{GL} / \mathrm{yr}$. The Plan did not propose any measures to reduce this overallocation, although it did provide that licensing for 'consumptive purposes' (by which it presumably means non-dewatering purposes) will not be allowed above $2.2 \mathrm{GL} / \mathrm{yr}$ so that 'groundwater levels ... will begin to recover once dewatering ceases'. ${ }^{289}$

While coal mining and associated dewatering has ceased in the Cardiff area, groundwater resources are also substantially over-allocated in that area, due mainly to allocations to coal-fired power stations. ${ }^{290}$ Power stations use a combination of groundwater from bores and water obtained from mine dewatering in the Premier region to meet their substantial water needs (Table 8).

Table 8 : Water access for power stations in the Collie Basin (2009) ${ }^{291}$

\begin{tabular}{|l|l|l|}
\hline Generator & Water use & Source \\
\hline $\begin{array}{l}\text { Muja Power Station } \\
(954 \mathrm{MW})\end{array}$ & $11 \mathrm{GL} / \mathrm{yr}$ & $\begin{array}{l}\text { Mine dewatering water } \\
\text { Bore water }\end{array}$ \\
\hline $\begin{array}{l}\text { Collie Power Station } \\
(340 \mathrm{MW})\end{array}$ & $4 \mathrm{GL} / \mathrm{yr}$ & $\begin{array}{l}\text { Mine dewatering water } \\
\text { Bore water }\end{array}$ \\
\hline $\begin{array}{l}\text { Bluewaters Power Station } \\
(200 \mathrm{MW})\end{array}$ & $3.25 \mathrm{GL} / \mathrm{yr}$ & Mine dewatering water \\
\hline
\end{tabular}

The 2009 Allocation Plan committed to a more proactive strategy to address over-allocation for groundwater resources in the Cardiff area, stating that 'no more water is available for allocation' and '[a]s current licences expire, the department will reduce allocations upon licence renewal. ${ }^{292}$

Licenced allocations in the Cardiff area have not reduced since 2009 - indeed, over-allocation increased between 2011 and 2012 (Table 9). From an examination of the Water Register it seems likely that this increase was due to the grant of a $4 \mathrm{GL}$ licence to electricity provider Synergy in January 2012, presumably to replace an expiring licence. ${ }^{293}$ The Department of Water advises that this increase in over-allocation was offset by the Department granting reduced entitlements to Synergy in the Premier subarea. ${ }^{294}$

\footnotetext{
${ }^{287}$ Department of Water, 'Upper Collie Water Allocation Plan' (Government of Western Australia, 2009) 9.

288 Ibid 6 .

289 Ibid 23.

290 Ibid.

${ }^{291}$ Figures sourced from Smart, A and Aspinal, 'Water and the Electricity Generation Industry: Implications of Use (National Water Commission, 2009), 38.

292 Ibid.

${ }^{293}$ Department of Water, The Water Register: Licence and Water Availability Register (17 June 2014) <http://www.water.wa.gov.au/ags/WaterRegister> (licence number 162660).

${ }^{294}$ Pers comm Andrew Cresswell, Department of Water, 22 April 2014.
} 
Over-allocation in the Premier subarea is currently about the same as in 2009. It increased between 2011and 2013 but declined in 2014. These fluctuations reflect changes in entitlements as licences were renewed or expired, and were driven by changes to mine plans and subsequent onground operations. ${ }^{295}$

Table 9: Over-allocation in Collie Groundwater Area (2009-2014)

\begin{tabular}{|l|l|l|l|l|l|l|}
\hline Resource & $\mathbf{2 0 0 9}$ & $\mathbf{2 0 1 0}$ & $\mathbf{2 0 1 1}$ & $\mathbf{2 0 1 2}$ & $\mathbf{2 0 1 3}$ & $\mathbf{2 0 1 4}$ \\
\hline Premier - Lower Collie & $2427 \%$ & $2427 \%$ & $2382 \%$ & $3136 \%$ & $3136 \%$ & $2455 \%$ \\
\hline Cardiff - Lower Collie & $256 \%$ & $256 \%$ & $256 \%$ & $296 \%$ & $296 \%$ & $296 \%$ \\
\hline Cardiff - Muja & $146 \%$ & $146 \%$ & $146 \%$ & $146 \%$ & $146 \%$ & $146 \%$ \\
\hline
\end{tabular}

\section{Case Study: Over-allocation in the Gnangara Groundwater System}

The Gnangara Groundwater Allocation Plan (2009) recognised that some management sub-areas had become over-allocated, and identified a number of management responses aimed at reducing the level of licenced abstraction in over-allocated areas - although without identifying a pathway or timeline for achieving this result.

The plan committed to refusing applications for new water entitlements in over-allocated areas; reducing Water Corporation's allocation for the Integrated Water Supply System; and recouping unused water entitlements. These management responses were implemented. There are two important points about how the latter management response was implemented. First, the reductions of entitlements (to a baseline of $120 \mathrm{GL} / \mathrm{yr}$ ) were only implemented in 2012 when the Water Corporation's licences expired and were renewed with a reduced entitlement. ${ }^{297}$ Second, the Water Corporation was given considerable flexibility to obtain increased allocations in lowstreamflow years, formalised through additional short term licences. ${ }^{298}$ These increased allocations were granted in accordance with the 'Variable Groundwater Abstraction Rule', which is considered further in Chapter 8.

Licenced entitlements in over-allocated groundwater areas increased between 2009 and 2012, before declining in 2013 and 2014 (Table 10). The main reasons for the reduction from 2012 appears to be reduced abstraction for the Integrated Water Supply System as rainfall recovered from the very dry winter of 2010 and desalination output increased (Table 11). Due to these factors the Water Corporation did not need to apply for an additional allocation to the same extent as in previous years.

Licenced entitlements in over-allocated areas with a high proportion of private entitlements, such

\footnotetext{
${ }^{295}$ Pers comm Andrew Cresswell, Department of Water, 18 June 2014.

${ }^{296}$ Pers comm Andrew Cresswell, Department of Water, 16 June 2014.

297 In 2009 the IWSS groundwater licences were renewed for a period of three years. The allocation was reduced to a baseline of 145GL/yr. In 2012, the licenses expired and subsequently renewed in 2012 with a reduced baseline allocation of 120GLyra, consistent with the Gnangara Groundwater Areas Allocation Plan. Pers comm Matt Viskovich, Department of Water, 23 May 2014.

298 Ibid.
} 
as the horticultural area of Wanneroo, did not experience any sustained reduction in entitlements, suggesting that the practice of recouping unused entitlements only made modest contributions to addressing over-allocation (Table 12).

Table 10 : Gnangara groundwater system: licenced entitlements in over-allocated areas 299

\begin{tabular}{|l|l|l|l|l|l|l|}
\hline & 2008/09 & 2009/10 & 2010/11 & 2011/12 & 2012/13 & 2013/14 \\
\hline $\begin{array}{l}\text { Total licensed entitlements } \\
(\mathrm{GL})\end{array}$ & 189.3 & 190.7 & 206.2 & 206.7 & 191.7 & 171.8 \\
\hline $\begin{array}{l}\text { Aggregate of allocation limits } \\
(\mathrm{GL})\end{array}$ & 170.4 & 170.4 & 170.4 & 170.4 & 170.4 & 170.4 \\
\hline
\end{tabular}

Table 11: Contributions of major water sources to the Perth metropolitan area water supply 300

\begin{tabular}{|l|l|l|l|l|l|}
\hline Year & $\mathbf{2 0 0 8 / 0 9}$ & $\mathbf{2 0 0 9 / 1 0}$ & $\mathbf{2 0 1 0 / 1 1}$ & $\mathbf{2 0 1 1 / 1 2}$ & $\mathbf{2 0 1 2 / 1 3}$ \\
\hline Groundwater (GL) & 146 & 120 & 164 & 158 & 140 \\
\hline Streamflow (GL) & 121 & 136 & 115 & 81 & 47 \\
\hline Desalination (GL) & 43 & 48 & 52 & 79 & 96 \\
\hline TOTAL (GL) & 245.5 & 244.2 & 241.7 & 240.5 & 241.5 \\
\hline
\end{tabular}

1: Total water supplied to Perth Metro area. Total volume excludes water transferred to South West and Goldfields Agricultural regions and system losses including environmental releases from some surface water dams to maintain downstream environment

Table 12: Licenced entitlements in over-allocated areas, Wanneroo ${ }^{301}$

\begin{tabular}{|l|l|l|l|l|l|l|}
\hline Year & $\mathbf{2 0 0 8 / 0 9}$ & $\mathbf{2 0 0 9 / 1 0}$ & $\mathbf{2 0 1 0 / 1 1}$ & $\mathbf{2 0 1 1 / 1 2}$ & $\mathbf{2 0 1 2 / 1 3}$ & $\mathbf{2 0 1 3 / 1 4}$ \\
\hline Groundwater (GL) & 27.4 & 26.6 & 25.9 & 25.4 & 25.5 & 25.4 \\
\hline
\end{tabular}

There are a number of different explanations for the reluctance to use licence amendment powers to address over-allocation. In the case of mine dewatering in Collie, for example, there has clearly been a deliberate policy decision to allow continued over-allocation in order to facilitate the ongoing operation of coal mining and coal-fired electricity generation in the area. However, we suggest that, in some cases (including in the case of private licensees on the Gnangara Mound), there are three features of the regulatory framework that discourage the use of powers to reduce licensed water allocations.

First, licensees have an expectation of a fixed annual volumetric water entitlement. It is true that prior to 2012 it was common practice for licences to include a condition that 'should the licensee's draw adversely affect the aquifer or other users in the area, the Department of Water may reduce

\footnotetext{
${ }^{299}$ Aggregated by the authors from figures provided by the Department of Water. The data is drawn from 37 subareas/aquifers in which licenced entitlements exceeded the allocation limit at any time over the period in question.

${ }^{300}$ Figures provided by the Water Corporation.

${ }^{301}$ Aggregated by the authors from figures provided by the Department of Water.
} 
the amount that may be drawn'. ${ }^{302}$ However, this is a limited expression of the statutory circumstances in which licences may be amended (it does not cover environmental impacts for example) and it is no longer the Department's practice to impose this condition.

Secondly, it is administratively onerous to address over-allocation through licence amendments and directions. Not only must this be done on an individual amendment/direction basis, but there are rights of comment and review available to each licensee. Given that a single review application in the State Administrative Tribunal could cost the Department of Water tens of thousands of dollars in legal fees and staff time, the Department would be reluctant, to say the least, to issue hundreds of directions or licence amendments to address a widespread allocation problem.

Finally, at least in relation to general licence amendments, there is the possibility of compensation claims being made. As discussed above, there are very broad exemptions to the rule that compensation is payable for reducing water allocations but there is still scope for expensive Tribunal cases reviewing decisions not to pay compensation.

Quite apart from the difficulty of addressing over-allocation problems through individual licence amendments, there are inherent problems of equity and transparency in dealing with a collective problem in this way. There is a real risk that different approaches will be negotiated with different licensees. Licensees may end up with lesser or greater cuts depending, for example, on their ability to access legal advice and the appeals system. It is far better for these issues to be addressed through a public planning process that applies the same rules to all licensees.

\subsection{An alternative approach: share-based entitlements}

We now turn to consider one of the fundamental reforms in the Intergovernmental Agreement on a National Water Initiative ('National Water Initiative'): the creation of a new water entitlements regime. In place of the traditional model of fixed term licences to access a specified volume of water each year, the National Water Initiative provides for rights to a 'perpetual or open-ended share of the consumptive pool of a specified resource, as determined by the relevant water plan'. ${ }^{303}$ The National Water Initiative provides that these rights will, among other things, be exclusive, tradeable, enforceable, and recorded in publicly-accessible water registers. Carruthers and Mascher have described these provisions as follows:

Taken together, these requirements ... focus on providing the holder of access entitlements with clearly defined rights that possess the traditional characteristics of a property right: exclusivity, alienability, and enforceability. However, by describing access entitlements as a "perpetual or openended share of the consumptive pool of a specified water resource, as determined by the relevant water plan", the National Water Initiative strives to deliver security and certainty while at the same time avoiding the problems associated with over-allocation.

\footnotetext{
302 The quoted condition appears on licences obtained in 2010 by Alex Gardner in response to a Freedom of Information request for water licences in the Carabooda, Lake Gnangara, Mariginiup, Neerabup, Nowergup and Eglington groundwater sub-areas. The Department of Water advised the authors that it was common practice to impose this condition prior to 2012, but that, following a review of licence conditions, the Department determined that it was more appropriate to rely on the licence amendment process to vary the volume of water the licensee could take under a licence pers comm Caroline Mellish, Department of Water, 22 November 2013.

${ }^{303}$ Council of Australian Governments, above n 11, para 28.
} 
The value of this entitlement regime in a drying climate is obvious. It has the potential to avoid the risk of over-allocation that is associated with granting fixed entitlements to a variable, and probably declining, resource. There are two particular advantages of the regime compared to Western Australia's current entitlement system: first, it makes clear to entitlement-holders from the outset that their groundwater allocation may be varied to keep overall allocations within sustainable limits; and, second, it is administratively easier to make such variations, because this can be done by adjusting the consumptive pool rather than individually amending licences (Figure 18).

Figure 18: Current entitlements vs National Water Initiative entitlements

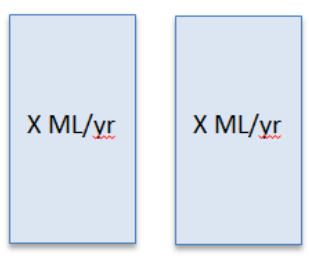

Current fixed volume entitlements

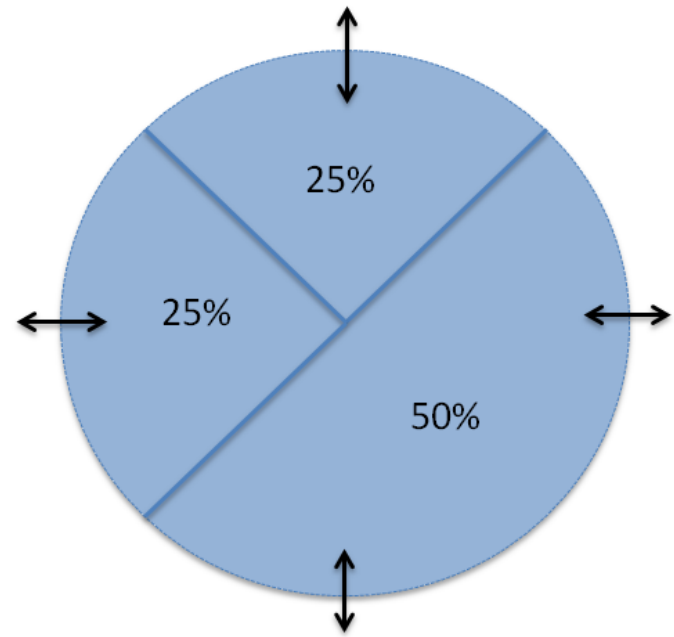

NWI share entitlements

Under the National Water Initiative, the rules about how consumptive pools can be varied are to be set out in statutory water allocation plans. Table 13 provides some examples, drawn from the approaches in jurisdictions that have implemented the National Water Initiative, as to how these rules can be framed.

Table 13: Examples of rules for varying the consumptive pool

\begin{tabular}{|c|c|c|}
\hline Approach & Planning context & Example of Rule \\
\hline $\begin{array}{c}\text { Specified } \\
\text { consumptive pool }\end{array}$ & $\begin{array}{l}\text { Management objectives can be met } \\
\text { by specifying a consumptive pool and } \\
\text { reviewing it at end of plan review }\end{array}$ & The consumptive pool is $1,262 \mathrm{ML} / \mathrm{yr}^{304}$ \\
\hline Average recharge & $\begin{array}{l}\text { Management objectives can be met } \\
\text { by maintaining an alignment between } \\
\text { recharge and consumption over the } \\
\text { medium term }\end{array}$ & $\begin{array}{l}\text { The consumptive pool is } 35 \% \text { of the average } \\
\text { annual recharge over the preceding } 10 \\
\text { years } 305\end{array}$ \\
\hline
\end{tabular}

\footnotetext{
${ }^{304}$ Example is drawn from Department of Land and Resource Management, 'Draft Alice Springs Water Allocation Plan 2013-2018' (2013) 52.

${ }^{305}$ This approach was used in Eyre Region Water Resources Planning Commitee, 'Water Allocation Plan for the Musgrave Prescribed Wells Area' (2001) 10 (although not in conjunction with periodic allocation determinations) and was discussed but not recommended in Goulburn-Murray Water, 'Review of the Katunga Water Supply Protection Area Groundwater Management Plan' (2012) 24-25.
} 


\begin{tabular}{|c|c|c|}
\hline $\begin{array}{c}\text { Groundwater level } \\
\text { trigger }\end{array}$ & $\begin{array}{l}\text { Saline intrusion needs to be } \\
\text { prevented by reducing groundwater } \\
\text { extraction when water levels fall } \\
\text { below a specified level }\end{array}$ & $\begin{array}{l}\text { If the average groundwater level is between } \\
530 \mathrm{~m} \text { and } 535 \mathrm{~m} \text { above sea level at } 15 \\
\text { September then the consumptive pool is } \\
140 \mathrm{ML} / \mathrm{yr}^{306}\end{array}$ \\
\hline Predicted discharge & $\begin{array}{l}\text { The dry season flow of a } \\
\text { groundwater-dependent river needs } \\
\text { to be maintained to meet } \\
\text { environmental and other public } \\
\text { benefit objectives }\end{array}$ & $\begin{array}{l}\text { Where the modelled dry season flow of the } \\
\text { Katherine River is between } 1.2 \text { and } 1.3 \text { cubic } \\
\text { metres per second then the consumptive } \\
\text { pool for that year is } 21.7 \mathrm{GL}^{307}\end{array}$ \\
\hline $\begin{array}{l}\text { Discretionary } \\
\text { determination }\end{array}$ & $\begin{array}{l}\text { There are multiple management } \\
\text { objectives and it isn't possible to } \\
\text { formulate a definite rule. }\end{array}$ & $\begin{array}{l}\text { The allocation is to be determined having } \\
\text { regard to: } \\
\text { - trends in underground water levels } \\
\text { - } \text { long term average sustainable yield } \\
\text { - historical water use } \\
\text { - } \text { anticipated water use } \\
\text { - } \text { licences in the area } \\
\text { - weather conditions, including } \\
\text { - } \text { treather forecasts in underground water quality } \\
\text { - for zones near the coast-the risk of } \\
\text { - } \quad \text { saltwater intrusion } \\
\text { recommendations made by the local } \\
\text { Advisory Group }{ }^{308}\end{array}$ \\
\hline
\end{tabular}

Other Australian jurisdictions have used a range of approaches to defining share entitlements. As illustrated by Table 14, there are a number of different ways in which a water access entitlement can be expressed. However, common features of all regimes are:

- it is clear from the outset that the entitlement is to a share of a variable consumptive pool; ${ }^{309}$ and

- a periodic allocation determination can proportionately vary the volume of water that may be taken by entitlement holders to ensure that total allocations are equal to the consumptive pool.

\footnotetext{
${ }^{306}$ Example is drawn from Government of Victoria, 'Loddon Highlands Water Supply Protection Area Groundwater Management Plan' (2012) 16 (but in that case the rule was that the allocation must be $75 \%$ of nominal volumetric entitlements).

${ }^{307}$ Example drawn from Department of Natural Resources, Environment, the Arts and Sport,, 'Water Allocation Plan for the Tindall Limestone Aquifer, Katherine 2009 - 2019' (2009) 30.

${ }^{308}$ Example is drawn from Queensland Government, 'Bowen Groundwater Management Area Water Sharing Rules: Seasonal Water Assignment Rules (WSS/2013/636, Version 4.02)' (2014). The rules incorporate mandatory relevant considerations set out in Water Regulation 2002 (Qld) reg 66.

${ }^{309}$ In the case of Victoria, entitlements do have a nominal volumetric allocation, but the nature of the entitlement is made clear by their name - they are called 'water shares': Water Act 1989 (Vic), Part 3A.
} 
Table 14: Examples of National Water Initiative-consistent water access entitlements

\begin{tabular}{|c|c|c|c|c|}
\hline $\begin{array}{c}\text { Jurisdiction } \\
\text { (groundwater area) }\end{array}$ & $\begin{array}{l}\text { Example of } \\
\text { entitlement }\end{array}$ & $\begin{array}{c}\text { Allocation } \\
\text { determination }\end{array}$ & $\begin{array}{c}\text { Annual amount } \\
\text { credited to } \\
\text { water account }\end{array}$ & $\begin{array}{l}\text { Allocation } \\
\text { instrument }\end{array}$ \\
\hline ACT (Cotter) ${ }^{310}$ & $\begin{array}{l}5 \% \text { of the } \\
\text { consumptive pool }\end{array}$ & $\begin{array}{l}\text { The consumptive } \\
\text { pool is } 2050 \mathrm{ML} / \mathrm{pa}\end{array}$ & $102.5 \mathrm{ML}$ & $\begin{array}{c}\text { Ministerial } \\
\text { determination } \\
\text { (disallowable } \\
\text { instrument; last } \\
\text { groundwater } \\
\text { determination 2007) }\end{array}$ \\
\hline NSW (Peel Valley) ${ }^{311}$ & 100 units/pa & $\begin{array}{c}1 \text { unit equals } \\
0.73 \mathrm{ML}\end{array}$ & $73 \mathrm{ML}$ & $\begin{array}{c}\text { Ministerial } \\
\text { determination } \\
\text { (annual) }\end{array}$ \\
\hline NT (Katherine) & $\begin{array}{c}\text { Nominal } \\
\text { entitlement of } \\
\text { 100ML/yr }\end{array}$ & $\begin{array}{c}\text { Allocation } \\
\text { percentage is } 100 \%\end{array}$ & $100 \mathrm{ML}$ & $\begin{array}{c}\text { Departmental } \\
\text { announcement } \\
\text { (annual) }\end{array}$ \\
\hline Victoria (Katunga) 312 & $\begin{array}{c}\text { Nominal } \\
\text { entitlement of } \\
\text { 100ML/yr }\end{array}$ & $\begin{array}{c}\text { Allocation } \\
\text { percentage is } 70 \%\end{array}$ & $70 \mathrm{ML}$ & $\begin{array}{l}\text { Water Authority } \\
\text { determination } \\
\text { (annual) }\end{array}$ \\
\hline
\end{tabular}

The National Water Initiative entitlements regime provides greater flexibility to effectively manage groundwater use in a drying climate. Whether it is successful in doing so will depend, in part, on the design of water allocation rules. The following case study provides an example of how these rules could be designed to anticipate climate change impacts and the needs of water users.

\section{Case Study: Climate change, groundwater and water allocation on the Eyre Peninsula}

A discussion paper on climate change and groundwater in South Australia's Eyre Peninsula ${ }^{313}$ has highlighted the risks of climate change for that area, and discussed the way in which allocation rules could be framed to address those risks.

The paper states that, while there are many sources of uncertainty in the work produced to date, modelling suggests a potential for groundwater recharge to decrease in the order of $30-50 \%$ by 2030 and $50-80 \%$ by 2070 under a high emissions scenario.

The paper notes that current groundwater management plans for this area, which are reviewed every five years, already use a ten year rolling average of recharge as the basis for setting water

\footnotetext{
${ }^{310}$ Example drawn from Minister for the Environment (ACT), 'Water Resources (Water available from areas) Determination 2007 (No 1)' (31 July 2007).

${ }^{311}$ Example drawn from Minister for Primary Industries (NSW), 'Available Water Determination Order for the Peel Valley Regulated, Unregulated, Alluvium and Fractured Rock Water Sources 2013' (26 June 2013).

312 Example drawn from Government of Victoria, 'Groundwater Management Plan for the Katunga Water Supply Protection Area' (2006) and Goulburn Valley Water, 'Katunga Water Supply System: Drought Response Manual' (2012).

${ }^{313}$ Eyre Peninsula Natural Resources Management Board, 'Discussion Paper: Climate Change and Groundwater' (Government of South Australia, 2010).
} 
allocations that vary in response to the climate.

For future water allocation plans, the paper suggests that 'there may need to be some trade-offs between adaptive management where allocations vary according to current (recent) resource condition trends and fixed allocations that provide better water security.'

One option suggested by the paper is to provide high security water entitlements that are fixed for five years, and other water entitlements that may have more variable allocations. This option can be seen as creating two consumptive pools; a high security pool from which are made high reliability annual allocations to the fixed entitlement holders, and a general security pool from which are made variable allocations to the general entitlement holders taking into account current recharge. As resource security is a 'zero-sum commodity' this will tend to give less security to ordinary water users. ${ }^{314}$

The 2013 Position Paper indicates that the new water resource management legislation will provide the basis to establish perpetual, share-based entitlements of the kind we have been discussing. This would not occur on enactment of the new legislation however: it would only apply in areas with statutory water allocation plans that provides for the introduction of such entitlements. ${ }^{315}$ As these plans are to be developed over time, it will be important to have interim arrangements and tools to achieve the required flexibility.

For areas not covered by statutory water allocation plans, the 2013 Position Paper proposes something of a hybrid between the current licensing system and the National Water Initiative entitlement regime: existing fixed term licences would continue, but the volume of water that may be taken under those licences would be able to be varied more easily. One example provided by the Position Paper is the use of 'periodic allocation announcements' that would involve 'a percentage change to volume available under the allocation issued periodically'. ${ }^{316}$

These are important reforms that should go a long way to overcoming the problems associated with the current entitlements system that we identified in section 6.2.

\section{Law Reform Recommendation: A more flexible entitlements system}

The legislation should provide greater flexibility to adjust levels of groundwater extraction through:

- a new system of water access entitlements that provide access to a share of a consumptive pool rather than to a fixed volume of water, with the allocation of water to the entitlement to be made consistent with the relevant statutory water allocation plan; and

- pending the introduction of those entitlements, powers to more easily vary the volume of water that may be taken under existing licences.

\footnotetext{
${ }^{314}$ John Quiggin, 'Uncertainty, Risk and Water Management in Australia' in Lin Crase (ed), Water Policy in Australia: The Impact of Change and Uncertainty (Resources for the Future, 2008) 67 ('In the presence of variable and uncertain supplies of water, or other resources, it is natural for users to seek security of access. It is, of course, possible to guarantee access for some users; however, resources security is, in large measure, a zero-sum commodity. The more security is given to one group of users, the less there is for anyone else'.)

${ }^{315}$ Department of Water, above n 70, 14-16.

${ }^{316}$ Ibid, 13-14.
} 


\subsection{Risk assignment and compensation}

The new water resource management legislation should provide for how the risk of loss from entitlement reductions made by plan amendments is assigned between water users and government. In all Australian jurisdictions that have implemented the National Water Initiative, periodic determination of the available water in a consumptive pool, made under a statutory water allocation plan, applies equally to all entitlement-holders (according to the terms of their entitlement) and is not compensable. However, permanent adjustments to the reliability or share volume of water access entitlements through plan amendments, either during the term of a plan or at the end of the plan term, raise more difficult questions of compensation. We consider those questions in this section. The issue of compensation associated with the transition from traditional licences to new share-based entitlements is considered separately in section 8.4 below.

One approach, put forward in the National Water Initiative, is to provide that reduced or less reliable water allocations associated with plan amendments or new plans ${ }^{317}$ may be compensable, depending on the reason for the reduction. Under these risk assignment provisions, risks arising under statutory water plans are to be shared over each ten year period in the following way:

- risks associated with 'seasonal or long-term changes in climate' and 'periodic natural events such as bushfires and droughts' are borne by entitlement-holders;

- risks associated with changes in government policy, such as new environmental objectives, are to be borne by government; and

- risks associated with improvements in the knowledge of water systems' capacity to sustain particular extraction levels are to be shared by water users and governments in accordance with a formula specified in the National Water Initiative. ${ }^{318}$

New South Wales, Queensland and the Commonwealth have implemented these provisions by making compensation conditional on a declaration by the Minister, when approving a plan or plan amendment, that the consumptive pool has been reduced for a particular reason, or for a specified combination of reasons. ${ }^{319}$

One important point about these risk assignment provisions is that there is no compensation for adjustments to the consumptive pool associated with 'seasonal or long-term changes in climate'. On the face of it, this provides the flexibility needed to keep total water allocations within sustainable limits in a drying climate. However, as a number of commentators including the National Water Commission have noted, there are practical difficulties in attributing reductions to

\footnotetext{
317 The National Water Initiative suggests that the risk assignment provisions should not apply to the initial statutory water allocation plans that transition to the new entitlements regime and address known over-allocation issues: Council of Australian Governments, above $\mathrm{n} 11$ paras 46, 47. New South Wales adopted this approach by providing that its risk assignment provisions only apply to plan amendments or replacement plans (see Water Management Act 2000 (NSW) ss 46). The Commonwealth takes a different approach, applying the risk assignment provisions to its first Basin Plan (see Water Act 2007 (Cth) s75).

318 Ibid, paras 48-50. Under paragraph 49 of the NWI, the formula for risks associated with new knowledge is as follows: i) water access entitlement holders to bear the first $3 \%$ reduction in water allocation under a water access entitlement; ii) State/Territory governments and the Commonwealth Government to share one-third and two-thirds respectively reductions in water allocation under water access entitlements of between 3\% and 6\%; and iii) State/Territory and Commonwealth governments to equally share reductions in water allocation under water access entitlements greater than 6\%. This only applies to 'risks arising under comprehensive water plans commencing or renewed after 2014'. ${ }^{319}$ Water Management Act 2000 (NSW) ss 46, 87AA; Water Act 2000 (Qld) Part 3; Water Act 2007 (Cth) s75.
} 
climate, government policy and new knowledge. ${ }^{320}$ This 'attribution problem' is borne out by the limited practical experience with applying the National Water Initiative risk assignment provisions. To our knowledge only the Commonwealth, through the Murray-Darling Basin Authority and the Commonwealth Environment Minister, has actually attempted to apply the rules. The Authority's difficulty in applying the risk assignment provisions is instructive. When faced with quantifying reductions due to new knowledge the Authority sought to 'identify the baseline knowledge on which the Basin state water resource plans were prepared and to compare this with the information used for preparing the Basin Plan.' The Authority said that it had 'examined the information on current Basin state plans that is available to it, and found that it is not possible to make a valid comparison'. ${ }^{321}$

Another important point is that the National Water Initiative risk assignment rules only apply to reductions in the availability of water for consumptive use. The National Water Initiative does not address the question of whether the holders of share-based entitlements get the benefit of an increase in a consumptive pool. This can be illustrated by a hypothetical example involving two groundwater areas (Figure 19). Let us assume that, under the first statutory water plan, each area has a specified consumptive pool of $100 \mathrm{ML}$ per annum. Ten years later, the second plan increases the consumptive pool in Area A by 10 per cent and reduces it in Area B by the same amount. As we have seen, the National Water Initiative rules would require an assessment of the reasons why the allocation limit was reduced in Area $B$, and compensation may need to be paid to entitlementholders depending on the outcome of that assessment. However, the National Water Initiative is silent on whether entitlement-holders in Area A would get the benefit of the increase in their consumptive pool, or whether this water would be available for allocation by government. In the discussion below, we presume that the rules governing the distribution of 'new' water added to the consumptive pool will be at the discretion of government, guided by the terms of the relevant statutory water allocation plan. This water could be shared among existing entitlement holders, retained as unallocated water or distributed in some other way.

\footnotetext{
${ }^{320}$ Quiggin, above n 314, 70-71; Phil Pagan, 'Adaptive Management' in Lin Crase (ed), Water Policy in Australia: The Impact of Change and Uncertainty (Resources for the Future, 2008) 224-225; John Bevacqua, 'Uncertainties in the Australian Water Availability Risk Assignment Framework: Implications for Environmental Water Reserve Managers' (2011) 30(2) Economic Papers: A journal of applied economics and policy 185; Productivity Commission, 'Market Mechanisms for Recovering Water in the Murray-Darling Basin: Final Report' (2010) 119; National Water Commission, 'Australian Water Reform 2009: Second Biennial Assessment of Progress in Implementation of the National Water Initiative' (2009) 188; National Water Commission, above n 202, 61.

${ }^{321}$ See Murray Darling Basin Authority, 'Guide to the Proposed Basin Plan: Overview' (Murray-Darling Basin Authority, 2010) 156. The Authority ended up recommending that $100 \%$ of the reduction in diversion limits be attributed to a change in Australian Government Policy, which was reflected in the final Basin Plan: see p155 of the Guide to the Proposed Basin Plan and Basin Plan 2012 (Cth) cl 6.13.
} 


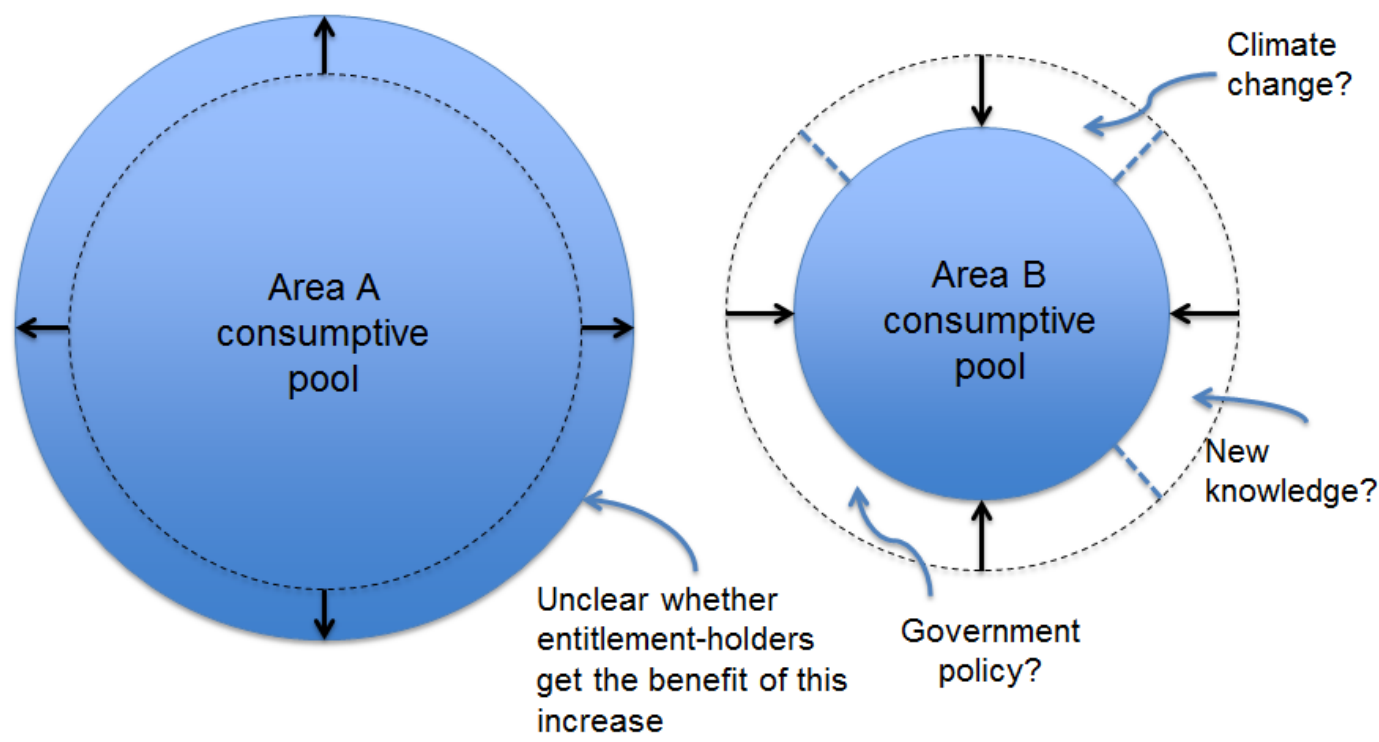

Given the practical difficulties with the National Water Initiative risk assignment rules, alternatives need to be considered. We outline some possible approaches below. Some of these approaches are already operating in other Australian jurisdictions.

\section{Option 1 - No compensation}

One option is to have no compensation rights. South Australia's Natural Resources Management Act 2004 takes this approach. The South Australian Government has adopted a Risk Assignment Policy which explains its position as follows:

In certain circumstances it may be necessary to reduce the amount of water available for licensed water use on an ongoing basis to protect the resource base due to reduced water availability or improved understanding of the water resource and/or environmental water requirements. Where reductions have been made in the past, they have occurred after extensive investigation of resource capacity, user and environmental requirements and engagement with the community to enable reasonable time to adjust to any permanent reduction or reduced reliability of licensed water use. The NRM Act provides that the Minister may reduce the volume of water made available to holders of water licences on an ongoing basis where necessary to protect the sustainability of the resource and/or water dependent ecosystems. Ensuring that the water made available for licensed water use is set at a level that is sustainable in the long term is fundamental to underpinning the integrity and reliability of rights to access the resource, which in turn supports investor confidence. Compensation is not payable by the South Australian Government for permanent reductions to water on water access entitlements. ${ }^{322}$ [emphasis added]

\section{Option 2 - Certainty for the term of a plan}

A second option would be to recognise that certainty is needed during the term of a plan but that a regular plan review at the end of the plan term is the opportunity for the community and the government to re-assess the long term sustainability of plan provisions of water for consumptive use and for environmental and other public benefit outcomes. Under this approach, compensation

${ }^{322}$ Department of Water (SA), 'Water Licensing: Risk Assignment Policy' (<https://www.waterconnect.sa.gov.au/Content/Publications/DEWNR/Water Licensing Risk Assignment Policy.pdf >. 
would be payable for plan amendments made during the term of a plan but not for changes flowing from an end-of-plan review. This is similar to an approach adopted by the Victorian Water Act 1989. Under that Act, the Minister must carry out 'long term water resource assessments' every 15 years. ${ }^{323}$ These assessments identify, among other things, whether there has been any decline in the long-term availability of surface water and groundwater in the area covered by the assessment. ${ }^{324}$ Following this assessment the Minister may permanently qualify water rights and no compensation is payable. ${ }^{325}$

\section{Option 3 - Quantitative limits}

A third option would be to provide that end of term plan changes could change the volume of water available to entitlement holders by a specified percentage - say 10 per cent. However, reductions in the consumptive pool greater than 10 per cent would be compensable and increases greater than 10 per cent would be available for allocation rather than benefiting existing entitlementholders (Figure 20). This is a new approach and has not, to our knowledge, been used in any Australian jurisdiction.

\section{Figure 20: An alternative approach to risk assignment}

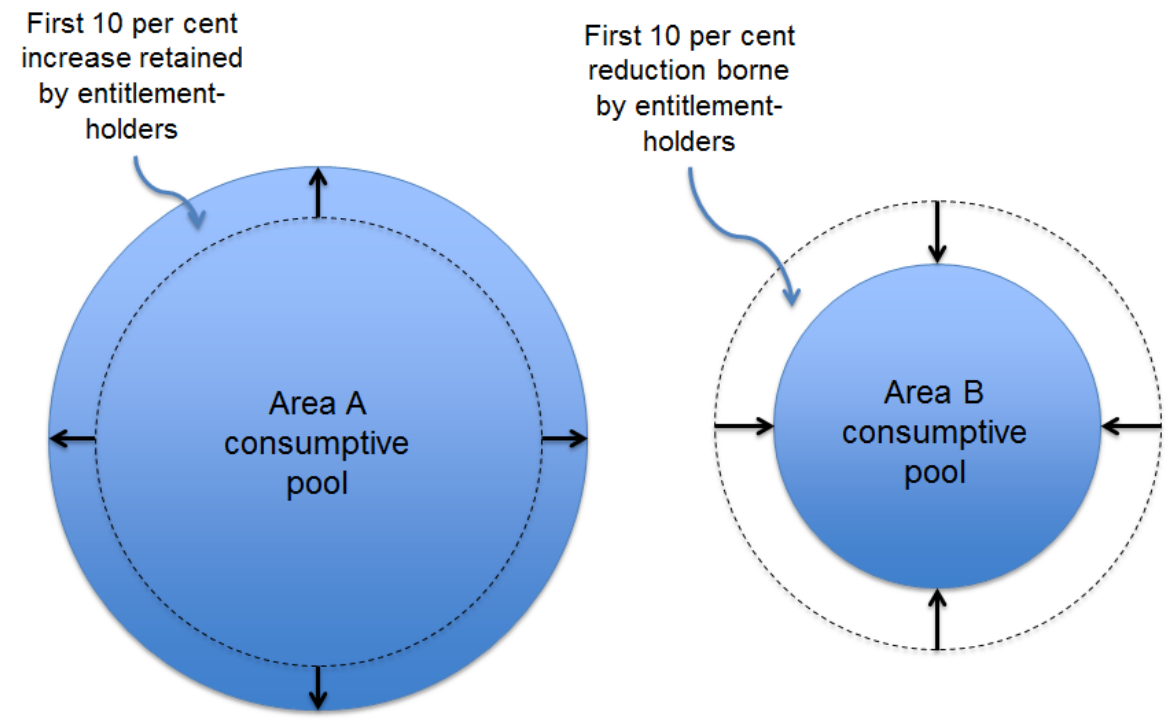

\section{Option 4 - Apply existing compensation rules to plan amendments}

The closest option to the 'status quo' would be simply to extend the current compensation rules in the RIWI Act to statutory water allocation plans and plan amendments. ${ }^{326}$ Under this approach, compensation would be not be payable where, in the Minister's opinion, a new plan or plan amendment would share the burden of reductions in water availability between entitlement holders in a fair and reasonable manner. However, compensation would be payable where entitlements are effectively acquired for a public purpose, such as where entitlements are reduced to allow water to be allocated for public water supply.

\footnotetext{
${ }^{323}$ Water Act 1989 (Vic) s22K.

324 Ibid S22L.

${ }^{325}$ Ibid s33AB.

${ }^{326}$ See section 1.3 above for an outline of the existing provisions.
} 
Option 5 - Apply modified version of existing compensation rules to plan amendments The State Government has proposed to combine elements of the existing compensation rules and the National Water Initiative risk assignment rules as follows: ${ }^{327}$

New risk assignment provisions will be included in the legislation specifying that the risk of permanent cuts to the entitlement is borne by the water user rather than the government if the cut is due to climate or natural events alone. If the cuts are not due to climate or natural events alone, the risks could be shared between the government and the water users.

Where the government bears the risk, for example, through a change in government policy, compensation is payable unless cuts to water entitlements are fair and reasonable. This means that cuts have to be equitable, but not necessarily equal.

The difficulty with this approach is that it imports the 'attribution problem' associated with the National Water Initiative rules, as discussed above.

\section{Option 6 - Set compensation rules through statutory plans}

For the sake of completeness, we note that a final option would be to allow compensation rules to be set through statutory plans, rather than being addressed in the primary legislation. This approach has been adopted in the Northern Territory. ${ }^{328}$ This option would only be suitable if it is not possible to formulate rules of general application for the primary legislation.

These options need to be assessed with a clear understanding of the legal context. We are considering a situation in which water users have a perpetual right to a share of a consumptive pool. That share is not being taken from them: rather, the rules for determining the consumptive pool are being adjusted in a way that affects all entitlement holders proportionately. Given this context, we suggest that Option 1 or Option 2 should apply, with a preference for Option 2. The regulatory framework should be able to accommodate, without the need for compensation, measures of general application aimed at keeping groundwater extraction within sustainable limits.

\section{Law Reform Recommendation: Risk assignment and compensation}

No compensation should be payable for adjustments to consumptive pools, or the rules governing the determination of consumptive pools, by regular end of term plan review and amendment. Permanent regulatory adjustments to consumptive pools and entitlements during the term of the plan would be compensable.

We make one final point about adjusting entitlements to the climate change induced reduction in water availability. As noted above, some Australian jurisdictions (New South Wales, Queensland and the Commonwealth) have legislated to implement the National Water Initiative proposition that the risk of such reductions falls on the entitlement holder. Those jurisdictions (South Australia and Victoria) that do not provide compensation at all clearly apply the same proposition for climate change reductions. There is also some ambivalence about the capacity of administrative agencies to ascertain sufficient information to attribute the portions of any reductions to the different causes recognised by the National Water Initiative risk assignment rules, at least in respect of knew

\footnotetext{
${ }^{327}$ Department of Water, above n 70, 24-25.

${ }^{328}$ e.g. Department of Natural Resources, above n 307, 29; Department of Land and Resource Management, above $n$ 304. The plans provide that all risks are borne by the water users.
} 
knowledge. However, if such information can be ascertained, there is a capacity to estimate the proportion of rainfall decline that may be attributed to human-induced climate change ${ }^{329}$ and to model the economic losses of the resulting reductions in water entitlements. ${ }^{330}$ While it is not possible to attribute a direct causal effect between certain GHG emissions and specific climate change harm, ${ }^{331}$ it is not necessary to do so in order to make GHG emitters responsible to some extent for the losses of those suffering current and future reductions in entitlements because of human-induced climate change. That responsibility could be less about compensation in a strict sense and more about adjustment assistance. It could be argued that water users who have lost access to water due to climate change should be assisted by an adaptation fund, funded by greenhouse gas emitters. This would acknowledge the links between those responsible for the emissions causing climate change and those who are suffering its harmful effects. ${ }^{332}$ Given the pre-eminent responsibility of the Commonwealth Government for climate change policy in Australia, it is sensible to suggest that the payment of structural adjustment assistance and the recovery of the cost from GHG emitters should be a Commonwealth responsibility. ${ }^{333}$

\subsection{1 mproved water accounting}

The National Water Initiative envisages more precise measurement and management of water resources and greater transparency in water resources accounting. Water accounting is a regulated process that involves identifying, measuring, recording and reporting information about water. ${ }^{334}$ Key elements of the water accounting framework are improved measurement or metering of water resource extraction and transparent public reporting of the metering data. Metering is the most precise form of measuring water extraction, but cheaper proxy measures can be adopted.

In 2004, the National Water Initiative anticipated metering according to national technical standards in the circumstances where: ${ }^{335}$

- a water management plan requires metering

- water access entitlements are traded

- there are disputes over sharing of available water

- new entitlements are issued

- there is otherwise a community demand.

As a general practical proposition, licensing water access provides a convenient legal basis for imposing conditions that require metering and reporting of water extraction. In 2009, the National

\footnotetext{
${ }^{329}$ Cai and Cowan, above $\mathrm{n} 139$, suggest that $50 \%$ of the reduction in South West rainfall can be attributed to humaninduced climate change.

${ }^{330}$ A Gardner, R Blakers and M Hartley, 'Legal Scenarios for Integrated Modelling', (submitted for publication June 2014), for research funded by the Cotton Research and Development Corporation and the National Centre for Groundwater Research and Training.

${ }^{331}$ Anvil Hill Project Watch Association Inc v Minister for Environment and Water Resources [2007] FCA 1480; 159 LGERA 8.

${ }^{332}$ Gardner, Bartlett and Gray, above n 22, 630.

${ }^{333}$ We acknowledge that one counter-argument to the reform proposed here is that it may introduce a form of 'moral hazard' - that is, a reduced incentive among water users to manage climate-related risks: compare Productivity Commission, 'Barriers to Effective Climate Change Adaptation' (2012), 313 (noting similar risks for disaster relief payments).

${ }^{334}$ Clare McKay and Alex Gardner, 'Water Accounting Information and Confidentiality in Australia' (2013) 41(1) Federal Law Review 127, 127.

${ }^{335}$ Council of Australian Governments, above $\mathrm{n} 11$ para 87.
} 
Water Commission stated that, ultimately, all surface and groundwater extractions should be 'licensed and metered or otherwise measured'. ${ }^{336}$ However, recognising the practical constraints on metering all groundwater extractions, it proposed that an interim risk-based approach be adopted by prioritising metering efforts where the level of water use was at or approaching full allocation or where the metering would enhance public confidence in compliance with the water resource management system, and where metering is otherwise cost effective.

It is not easy to ascertain the extent of metering of water licence extraction in Western Australia but it is a low proportion of licensees. ${ }^{337}$ Current policy is that a standard metering condition applies to licensees with an annual allocation greater than $500 \mathrm{ML}$, though metering may be required in some situations where the annual allocation is less than $500 \mathrm{ML} .{ }^{338}$ Metering is required as a prerequisite to trading. The standard policy is that licensees should pay for the installation, maintenance, reading and reporting of meters. However, the State has paid, including with Commonwealth Water Smart funding, for the installation and maintenance of meters in trials to extend metering over priority areas of the State, especially Gnangara Mound. ${ }^{339}$ In 2009, the Department of Water published Strategic Policy 5.03 - Metering the taking of water, a Metering Implementation Plan, and the Rights in Water and Irrigation (Approved Meters) Order 2009 for the purpose of extending metering across the State to all licences with annual allocations greater than $50 \mathrm{ML}$, and with Government funded installation of meters in priority areas for licence entitlements of greater than $5 \mathrm{ML}$. The Gnangara Mound metering trial 2006-2010 showed significant benefits from metering in exposing high rates of unauthorised extraction that were gradually reduced, even though there was little legal enforcement action taken. ${ }^{340}$ Alas, Commonwealth funding for the metering program did not continue so the State retreated to its former (now current) policy requiring metering only for licences with annual allocations above $500 \mathrm{ML} .{ }^{341}$ The State can also gather groundwater data from the Groundwater Assessment Network of Monitoring Bores (approximately 2,300), most of which are in the South West and some of which are telemetered. ${ }^{342}$

Overall, it is clear that the level of licence metering and reporting and the level of Departmental monitoring need to be greatly increased to obtain adequate information for groundwater modelling, planning and management. This will become increasingly important as groundwater resources are

\footnotetext{
${ }^{336}$ Australian Government, National Water Commission, Second Biennial Assessment of Progress in Implementation of the National Water Initiative, 2009, 46.

337 Some figures are given by Madeleine Hartley, "Problematic governance of groundwater use efficiency on the Gnangara system, Perth", (2013) Australian Environment Review 496-500.

${ }^{338}$ Government of Western Australia, Department of Water, Securing Western Australia's water future: Position paper reforming water resource management, September 2013, section 3.3.3, p.20.

339 Government of Western Australia, Department of Water, Strategic Policy 5.03: Metering the taking of water, June 2009, p.5 ff.

${ }^{340}$ Sarah Robertson, "A Regulatory Framework for Monitoring and Enforcement of Water Access Rights in Western Australia" (2014) 27(2) UWA L Rev 215.

${ }^{341}$ K Robertson, The Sunday Times, 3 February 2013, "Olympic-size water rort at Gnangara Mound": http://www.theaustralian.com.au/news/olympic-size-water-rort-at-gnangara-mound/story-e6frg6n6-1226567497850 . See also, Australian Government, National Water Commission, Assessment of groundwater licensing, metering and extraction estimation arrangements and techniques in Australia, Waterlines Report Series No 83, June 2012, p.13.

${ }^{342}$ Government of Western Australia, Department of Water, "Strategic Water Information and Monitoring Plan, Western Australia" June 2011, lodged with the Bureau of Meteorology, <http://www.bom.gov.au/water/regulations/fundingProgram/swimps.shtml>.
} 
placed under pressure from climate change. ${ }^{343}$ The Department of Water recognises this. It is investing in improved groundwater monitoring and proposes increasing the level of groundwater licence metering. ${ }^{344}$ In the 2013 Position Paper, the Department says that increased metering would be staged over a period of time, ensuring that:

- within two years from mid-2014, all groundwater licences with annual allocations greater than $500 \mathrm{ML}$ include a licence condition for metering

- within five years, all groundwater licences and multi-user surface water licences with annual allocations of less than $500 \mathrm{ML}$ will include a licence condition for measurement.

The proposed legislation will provide that all water access entitlements require metering, which will need to be implemented as statutory water allocation plans are adopted.

The design of legislation to implement these propositions is not difficult. Under the existing regulatory framework the Minister (or departmental delegate) may cause a meter to be installed, or require a licensee to install a meter. ${ }^{345}$ Once a meter has been installed the licensee must maintain the meter in good condition, ${ }^{346}$ pay the costs of repairs and testing, and not interfere with the meter. ${ }^{347}$ The legislation could also provide for the Department to recover the cost of providing metering if a licensee chose not to install, maintain and read a meter. ${ }^{348}$ The essence of the existing legislative provisions for metering could be incorporated into the reformed legislation with new provisions supporting metering of water access entitlements.

The key issue in extending metering has been the political assessment by the State Government and community interest groups of the costs and benefits of metering, including the costs and benefits of compliance and enforcement action if metering data shows unauthorised extraction. If meter readings provide evidence that water use exceeds licenced limits, the current legislation gives the Minister (or departmental delegate) a number of enforcement options, including to:

- issue a direction ordering compliance with the licence condition; ${ }^{349}$

- issue a notice suspending or cancelling the licence; ${ }^{350}$

- issue an infringement notices requiring payment of a modified penalty; ${ }^{351}$ or

- prosecute the licensee. $^{352}$

The enforcement regime could be strengthened by provisions that make it an offence for a licensee to fail to install a meter or report a meter reading contrary to licence condition as well as increasing the sanctions and penalties for unauthorised taking of water. ${ }^{353}$

\footnotetext{
${ }^{343}$ Management of areas at risk of seawater intrusion, for example, require particularly close monitoring.

344 "Strategic Water Information and Monitoring Plan", ibid, p.76, and Department of Water, Securing Western Australia's water future: Position paper - reforming water resource management, September 2013, section 3.3.3.

${ }^{345}$ Rights in Water and Irrigation Act 1914 (WA) sch 1 cl 46.

${ }^{346}$ Rights in Water and Irrigation Act 1914 (WA) sch 1 cl 46(2)(a).

${ }^{347}$ Rights in Water and Irrigation Regulations 2000 (WA) Part 4A.

${ }^{348}$ Western Australia, Economic Regulation Authority, Inquiry into Water Resource Management and Planning Charges, 2011, section 5, Water Metering Fees and Charges.

${ }^{349}$ Rights in Water and Irrigation Act 1914 (WA), sch 1, cl 18(1).

${ }^{350}$ Rights in Water and Irrigation Act 1914 (WA), sch $1 \mathrm{cl} 25(1)$ and (2)(c).

${ }^{351}$ Rights in Water and Irrigation Regulations 2000 (WA), r 51.

${ }^{352}$ Rights in Water and Irrigation Act 1914 (WA), s 5C.

${ }^{353}$ Sarah Robertson, above n 340.
} 
The real issue of reform is in the transparent public reporting of licence conditions requiring metering and of metering data. Presently, there is no publically accessible record of this information. The water register shows details identifying the licensee, the term of the licence, and the maximum annual allocation. Short of applying under the Freedom of Information Act 1992 (WA) and demonstrating that disclosure of the information is in the public interest, it is not possible for any person, even a neighbour, to discover whether a water licence is subject to a metering condition and whether the metering data show compliance with the licence entitlement. There is a strong case for the State to adopt an "information based regulation" approach and to make this information available through the on-line water register. ${ }^{354}$ Provision can be made for licensees to apply for water metering data not to be published if there are genuine and demonstrable concerns of commercial confidence. There is a very strong public interest in the transparent availability of water accounting data and the water resources legislation should reflect a presumption that the information is publically available unless a licensee can show good reasons for non-disclosure.

A final reform that could be considered part of improved water accounting is a shift from 'gross' to 'net' water entitlements. Under the present 'gross' system the return flow of water into a groundwater system is not taken into account in the specification of water entitlements. If, for example, an irrigator extracts $100 \mathrm{ML}$ but $50 \mathrm{ML}$ of this amount seeps back into the aquifer, the irrigator must have a licence that authorises the extraction of the 'gross' amount of $100 \mathrm{ML}$ rather than the 'net' amount of 50ML. This approach can lead to perverse results that become more noticeable as groundwater systems become fully allocated. For example:

- In a fully allocated system with 'gross' entitlements, the introduction of efficient drip irrigation can reduce the amount of water returning to the aquifer and cause the aquifer to become over-allocated ${ }^{355}$

- A 'gross' accounting system may be seen as unfair by water users once they pay for water, which will increasingly be the case as more aquifers become fully allocated and trading becomes the only option to obtain new water.

Net water accounting systems are used in the United States. Under Colorado law, legal action can even be taken in some circumstances against a water user that reduces the return flow of water to the detriment of other water users. ${ }^{356}$ Net water accounting is used less frequently in Australia. The Water Management Act 2000 (NSW) does provides the capacity for return flows to be credited to the original user ${ }^{357}$, but has not yet developed the detailed policy and regulations that would allow this to happen. The New South Wales government has indicated that such a policy will be prepared by $2015 .{ }^{358}$ Given the potential advantages of net water accounting in a drying climate,

\footnotetext{
${ }^{354}$ Clare McKay and Alex Gardner, "Water accounting information and confidentiality in Australia" (2013) 41 FLR 1.

355 Mike Young, 'Sharing Groundwater: Options for the Introduction of Shares as a Means to Define Groundwater Entitlements in the South East of South Australia' (2005) 11-12; Michael D. Young and Jim C. McColl, 'Double trouble: the importance of accounting for and defining water entitlements consistent with hydrological realities' (2009) 53(1) Australian Journal of Agricultural and Resource Economics 19.

${ }^{356}$ Madelaine Hartley, Regulating groundwater use efficiency for sustainable development: the experiences of Colorado, the Namoi Catchment, and the Gnangara Mound (forthcoming) (PhD Thesis, University of Western Australia, 2014 ) 83.

${ }^{357}$ Water Management Act 2000 (NSW), ss75, 76.

${ }^{358}$ NSW Office of Water, 'Capability and Priority Programs 2013-2015' (2013) 20.
} 
Western Australia should at least follow New South Wales by providing a statutory basis to introduce net accounting where it is appropriate to do so.

\section{Law Reform Recommendation: Improved water accounting}

The legislation should provide for:

- the implementation of increased metering as proposed by the 2013 Position Paper

- a strengthening of enforcement provisions for non-compliance with licence conditions requiring metering and reporting

- reform of the provisions for the water register to mandate on-line publication of licence conditions for metering and of the metering data unless the licensee can show a good reason for non-disclosure

- the capacity to introduce 'net' accounting for groundwater entitlements. 


\section{Greater use of water markets}

\subsection{Water markets and climate change adaptation}

A number of commentators have identified the value of water markets in promoting productive and efficient water use, particularly under conditions of water scarcity. As Skurray explains:

The expected benefits of trading in water, or in water entitlements, include the promotion of both physical and economic efficiency in water use, the former through price signals, and the latter through improved flexibility in the allocation of the resource among uses and locations. These benefits are particularly desirable in contexts of full- or over-subscription of available water resources. $^{359}$

The Garnaut Climate Change Review, National Water Commission and a number of academic commentators have identified water markets as an important climate change adaptation mechanism. ${ }^{360}$ The National Water Commission, for example, has highlighted the benefits of water markets in reallocating water to more productive uses in a climate change context:

Water markets have proven to be effective in reallocating water to its highest valued use, particularly during severe droughts. Because climate change is likely to lead to both rapid and cumulative changes in the supply of and demand for water, water markets will be an important adaptation mechanism to ensure that maximum value is obtained from Australia's scarce water resources. ${ }^{361}$

The experience of water trading in the Murray Darling has been cited as an example of the ability of water markets to reduce the economic impact of droughts. The National Water Commission concluded, based on economic modelling, that water trading in the southern Murray Darling Basin reduced the impact of drought over a five year period from $\$ 11.3 \mathrm{~b}$ to $\$ 7 \mathrm{~b}$. ${ }^{362}$

We accept that water markets have the potential to play an important role in promoting productive and efficient water use in a drying climate. This chapter considers the potential for regulatory reforms to promote the effective use of water markets in two areas: the initial allocation of groundwater and groundwater trading.

\footnotetext{
${ }^{359}$ James H. Skurray, Ram Pandit and David J. Pannell, 'Institutional impediments to groundwater trading: the case of the Gnangara groundwater system of Western Australia' (2013) 56(7) Journal of Environmental Planning and Management 2.

${ }^{360}$ Ross Garnaut, The Garnaut Climate Change Review (Cambridge University Press, 2008) 373-375; National Water Commission, above n 202, xv, xvii, 46; Jonathon H Adler, 'Water Marketing as an Adaptive Response to the Threat of Climate Change' (2008) 33(3) Hamline Law Review 729; Anita Foerster, 'Australian water law: adapting to climate change?' (Paper presented at the IUCN environmental law colloquium 2011); Priyanka Sundareshan, 'Using the Transfer of Water Rights as a Climate Change Adaptation Strategy: Comparing the United States and Australia' (2010) 27(3) Arizona Journal of International and Comparative Law 911; Dan Tarlock, 'How Well Can Water Law Adapt to the Potential Stresses of Global Climate Change?' (2010) 14 University of Denver Water Law Review 1, 20.

${ }^{361}$ National Water Commission, above n 202.

${ }^{362}$ National Water Commission, 'Impacts of water trading in the southern Murray-Darling Basin between $2006-07$ and 2010-11' (2012) xii.
} 


\subsection{Allocating groundwater}

\section{Limitations of the current regulatory system}

There are a range of different approaches that can be taken to the allocation by government of rights to extract groundwater. These include:

- A first-in, first-served approach, under which licence applications are decided individually in the order in which they are received;

- A merit selection approach, under which government assesses the relative merits of water uses proposed by multiple applicants after a call for expressions of interest; or

- A market-based approach, under which the person who is willing and able to pay the most gets access to the groundwater resource.

As will be clear from our outline of the licensing process in Chapter 1, the RIWI Act is best suited to the first approach, which has in fact been the dominant one to date.

The RIWI Act does not provide effectively for a merit selection approach. It is true that the Minister (or delegate) must have regard to whether the grant of a licence application will 'prejudice other current and future needs for water', ${ }^{363}$ but this is not the same as calling for expressions of interest and ranking applicants on a merit basis. There is no provision in the Act to place the usual licensing process on hold and call for expressions of interest in this way.

The RIWI Act does not provide effectively for a market-based approach either. It does provide that the Minister may, in some circumstances, enter into an agreement to grant a licence in return for payment of an agreed amount. ${ }^{364}$ However, it is not clear what methods can be used to determine the amount of this payment, ${ }^{365}$ and there is no process to place the ordinary license application process or appeals process on hold to allow an auction or other market-based release of water to take place.

Notwithstanding these limitations, the Department has indicated in a number of statutory plans that it may allocate water in the future using merit selection, sale, auction or tender - and as we shall see it has in fact used merit selection processes. These approaches to allocating water do not have a strong foundation under current law.

\section{Allocating groundwater in the South West: the experience to date}

To date no groundwater has been released through a market-based approach. The dominant practice in the South West has been to use water plans to reserve water for public water supply, and then use water licensing to allocate the remaining 'licensable component' for free on a first-in, first-served basis. Under this approach priority between licence applicants is determined by the order in which applications were received. There have, however, been limited experiments with

\footnotetext{
${ }^{363}$ Rights in Water and Irrigation Act 1914 (WA) sch 1, cl 7(2)(d).

${ }^{364}$ Rights in Water and Irrigation Act 1914 (WA) sch 1, cl 40.

${ }^{365}$ Compare Rights in Water and Irrigation Act 1914 (WA) sch 1, cl 41(3) which, unlike cl 40, specifically provides that 'the amount to be paid by consideration may be established by public auction or tender or private treaty'; see Vivian Chung, 'Making Waves: An Overhaul of Western Australia's Legislative Framework for the Allocation of Water - Part II' (2007) 26(4) Australian Resources and Energy Law Journal 381, 389-390.
} 
merit selection in the South West. The following case studies provide examples of these 'first-in, first-served' and merit selection approaches respectively.

\section{Case Study: Groundwater allocation in Mingenew, Arrowsmith Groundwater Area ${ }^{366}$}

Mingenew is a wheat and sheep farming area in the northern wheatbelt, around $90 \mathrm{~km}$ south-east of Geraldton. Approximately $120 \mathrm{~km}$ to the east of Mingenew is the Karara iron ore mine, a joint venture between an Australian iron ore company and China's second-biggest iron ore producer, Ansteel.

In 2010 this joint venture, through Karara Mining Limited (Karara), applied to the Department of Water for a licence to take $5.3 \mathrm{GL} / \mathrm{yr}$ of groundwater from the Leederville-Parmelia aquifer beneath Mingenew, in order to transport the water by pipeline to its mine for use in magnetite processing.

The grant of Karara water licence application would mean that the groundwater resource in question would be fully allocated (Table 15).

Table 15: Water available from the Leederville-Parmelia aquifer in the Mingenew subarea prior to grant of the Karara water licence $(\mathbf{2 0 1 0})^{367}$

\begin{tabular}{|l|l|l|l|l|l|}
\hline $\begin{array}{l}\text { Allocation limit } \\
\text { (GL/yr) }\end{array}$ & $\begin{array}{l}\text { Public water } \\
\text { supply } \\
\text { (GL/yr) }\end{array}$ & $\begin{array}{l}\text { Exempt } \\
\text { unlicensed } \\
\text { (GL/yr) }\end{array}$ & $\begin{array}{l}\text { Licensable } \\
\text { component } \\
\text { (GL/yr) }\end{array}$ & $\begin{array}{l}\text { Existing } \\
\text { licences (GL/yr) }\end{array}$ & $\begin{array}{l}\text { Available for } \\
\text { licensing } \\
\text { (GL/yr) }\end{array}$ \\
\hline 8.2 & 2 & 0.04 & 6.16 & 0.84 & 5.32 \\
\hline
\end{tabular}

The Karara application was advertised in local and state newspapers on 11 October 2010. The application provoked considerable community concern. Two public meetings were held. Karara presented on the project and released a hydrogeological report, which included modelling of drawdown under different climate scenarios. The Department received 27 written submissions, many of which raised concerns that the allocation of the remaining available water to Karara would inhibit future development of agricultural businesses. ${ }^{368}$

In the course of the application process, Karara amended its application to apply for 5GL/yr and it was granted a 5 year, $5 \mathrm{GL} / \mathrm{yr}$ licence on 31 August 2011. While no reasons for decision were published, a Departmental briefing note (obtained by the authors under a freedom of information application) does show that community concerns about alternative uses of the water were considered. The note deals in turn with each of the relevant considerations set out in Schedule 1, Clause 7(2) of the RIWI Act, including whether the proposed taking and use of the water 'may

\footnotetext{
${ }^{366}$ Material for this case study is drawn primarily from Department of Water, 'Arrowsmith Groundwater Allocation Plan' (2010); Department of Water, 'Arrowsmith Groundwater Allocation Plan: Evaluation Statement 2010-2011' (2011) and documents obtained from the Department of Water through a freedom of information application. The authors also thank Rhys Houlihan, Manager Environmental Services, Karara Mining Ltd and Aidan Kelly, Matrix Approvals for the opportunity to discuss the Karara proposal.

${ }^{367}$ Department of Water, 'Arrowsmith Groundwater Allocation Plan' (2010) 10; the figures for existing licences were supplied by the Department of Water.

${ }^{368}$ Department of Water, 'Briefing Note: Application from Karara Mining Limited for a licence of 5GL from the Parmelia Aquifer in the Mingenew Subarea' (August 2011).
} 
prejudice other current and future needs for water'. It notes that 'with continuing changes to climate, landholders may seek to diversify their activities to generate new sources of income' but also that it is difficult to account for possible future projects given that they were, at present, not well defined. ${ }^{369}$

The briefing note also makes clear that the 'first in, first served' policy was a very important factor in the decision, stating that 'the policy of 'first in, first served' remains the primary principle for allocating water until the resource approaches full allocation'. ${ }^{370}$ It appears that the aquifer in question was not considered to be in the category of 'approach[ing] full allocation' because prior to the application more than $30 \%$ of the resource was available for licensing. ${ }^{371}$

This case study illustrates that while allocations of water are not made purely on a 'first in, first served' basis under the current regulatory framework, significant weight is given to this principle. Without expressing a view on the relative merits of mining and horticulture in the Mingenew case, this does raise the problem acknowledged by the Department of Water in its discussion paper on the 'first-in first-served' policy: because water is allocated for free to the first person to apply for it, it is not necessarily allocated to its best use. This may not matter much when water resources are plentiful, but it is becoming increasingly important in the South West in the face of the twin pressures of climate change and increasing demand. ${ }^{372}$ While it is not central to our current discussion, we also note in passing one other issue raised by the case study: that objectors to a licence application have no right of appeal (see Appendix $\mathbf{J}$ for further comment on this issue).

If the first-in first-served approach has its drawbacks, so too has the experiment with a merit-based selection process used in the Gingin Groundwater area, as the following case study shows.

\section{Case study: Merit-based selection process, Gingin Groundwater Area}

The Gingin Groundwater Area is located around $90 \mathrm{~km}$ north of Perth and covers an area of about 6000 square $\mathrm{km} .{ }^{373}$ The area contains substantial groundwater resources in 9 different types of aquifer systems. ${ }^{374}$ Groundwater in the area is used for a variety of purposes including public water supply, agriculture and mining. ${ }^{375}$

Licences in the area had traditionally been granted under a 'first in, first served' approach, but as competition for available groundwater intensified it was questioned whether this approach was 'appropriate from an equitable water sharing perspective'. ${ }^{376}$

The 2002 Water Allocation Plan outlined a new approach, which had been developed jointly by the Department and the Gingin Water Resources Advisory Committee (a local advisory committee with

\footnotetext{
369 Ibid 7-9.

370 Ibid 14.

371 lbid.

Australia, 2013) 2.

374 Ibid 5-6.

${ }^{375}$ Water and Rivers Commission, above n 223.

${ }^{376}$ Ibid 20.
}

372 Department of Water, 'Discussion Paper: Review of First-in First-served Policy' (2011)287, 3-4.

${ }^{373}$ Department of Water, 'Gingin Groundwater Allocation Plan: Draft for Public Comment' (Government of Western 
representation from water users ${ }^{377}$ ). Under this new approach:

- a conventional 'first-in, first-served' approach would apply until a resource is $90 \%$ allocated;

- when the 90 per cent allocation limit is reached the Department would call for expressions of interest ('EOI') and licence applications;

- if the water sought in the applications exceeds the allocation limit, the applications would be assessed by the Gingin Water Resources Advisory Committee using a merit selection process;

- the Advisory Committee would provide advice to the Department on its assessment, and the Department would advise the EOI applicants whether they were successful or unsuccessful;

- unsuccessful EOI applicants would have their licence applications refused, and successful applicants would proceed through the licence assessment process. ${ }^{378}$

By early 2003 the Seabird superficial aquifer, located within the Gingin Groundwater Area, had reached the 90 per cent allocation limit, and the Department called for expressions of interest in the remaining water. 15 expressions of interest were received seeking a total of 3,192,680 kl/yr. ${ }^{379}$ This exceeded the $2,341,794 \mathrm{kl} / \mathrm{yr}$ that was available for allocation. ${ }^{380}$

Potential EOI applicants were provided with a questionnaire that requested information on a range of topics, including:

- whether the applicant owned the property;

- the purpose for which groundwater is required;

- whether the applicant had previously been refused a licence, and, if so, on what grounds;

- whether the application related to the expansion of an existing development;

- whether the proposed development would be the applicant's primary source of income;

- whether the proposed development would create employment, and, if so, to what extent; and

- $\quad$ how the proposed development would benefit the local community. ${ }^{381}$

In May 2003 the Advisory Committee assessed the expressions of interest and ranked them in a matrix. A copy of that matrix, obtained by the authors through a freedom of information application, is reproduced at Figure 21. As is apparent from the extract, no water was available for allocation once it was notionally allocated to the first 13 applicants, meaning that the remaining two applicants were unsuccessful.

The EOI process did allow an assessment of the relative merits of different water uses in a way that would not have been possible under the 'first in, first served' approach. However, subsequent

\footnotetext{
377 Section 26GK of the RIWI Act provides for the appointment of local advisory committees.

${ }^{378}$ Water and Rivers Commission, above n 222, 21-25.

${ }^{379}$ Water and Rivers Commission, Strategy Merit Selection Seabird Sub-Area (undated document obtained by the authors in March 2014 through a freedom of information application).

380 lbid.

${ }^{381}$ This information is drawn from Water and Rivers, Merit Selection Kit: Water Allocation - Guilderton Subarea, Gingin Groundwater Area (undated document obtained by the authors in March 2014 through a freedom of information application) and the assessment matrix at Figure 21.
} 
commentary identified a number of problems with the process, including the subjective nature of the assessment criteria and the time, skills and resources needed to assess EOIs. ${ }^{382}$ The Department concluded, in a review of alternatives to the 'first in, first served' policy, that a merit selection approach was 'the most costly and challenging to implement'. ${ }^{383}$

Figure 21: Assessment of Expressions of Interest in the Seabird Subarea, Gingin

\begin{tabular}{|c|c|c|c|c|c|c|c|c|c|c|c|}
\hline $\begin{array}{l}\text { Applicant } \\
\text { Criteria } \\
\end{array}$ & ह & 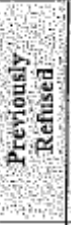 & 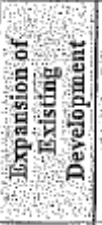 & 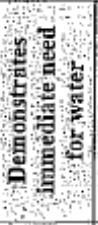 & 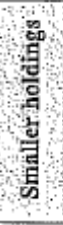 & 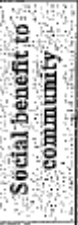 & है: & 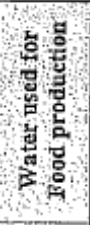 & 焉 & 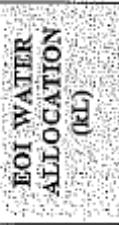 & $\frac{6}{6}$ \\
\hline & $\checkmark$ & $\checkmark$ & $\checkmark$ & $\checkmark$ & $\cdot \checkmark$ & $\checkmark$ & $\checkmark$ & $\checkmark$ & $\checkmark$ & 36,800 & 9. \\
\hline & $\checkmark$ & $\checkmark$ & $\checkmark$ & $\checkmark$ & $\checkmark$ & $\checkmark$ & $\checkmark$ & $\checkmark$ & $\checkmark$ & 12,350 & 9 \\
\hline & $\checkmark$ & & $\checkmark$ & $\checkmark$ & $\checkmark$ & $\checkmark$ & $\checkmark$ & & $\checkmark$ & 70,800 & 7 \\
\hline & $\checkmark$ & $\checkmark$ & $\checkmark$ & $\checkmark$ & $\checkmark$ & $\checkmark$ & $\checkmark$ & $\checkmark$ & $\checkmark$ & 12,000 & 9 \\
\hline & $\checkmark$ & & $\checkmark$ & $\checkmark$ & $\checkmark$ & & $\checkmark$ & $\checkmark$ & $\checkmark$ & 37,900 & 7 \\
\hline & $\checkmark$ & & & $\checkmark$ & $\checkmark$ & & $\checkmark$ & $\checkmark$ & & 44,650 & 5 \\
\hline & $\checkmark$ & $\checkmark$ & $\checkmark$ & $\checkmark$ & $\checkmark$ & & $\checkmark$ & $\checkmark$ & $\checkmark$ & 26,650 & 8 \\
\hline & & & & & $\checkmark$ & & $\checkmark$ & $\checkmark$ & . & 0 & 3 \\
\hline & $\checkmark$ & $\checkmark$ & $\checkmark$ & $\checkmark$ & $\checkmark$ & & $\checkmark$ & $\checkmark$ & $\checkmark$ & 22,650 & 8 \\
\hline & & & & $\checkmark$ & & & & $2 / 3 \checkmark$ & & 0 & $12 / 3$ \\
\hline & $\checkmark$ &. & $\checkmark$ & $\checkmark$ & $\checkmark$ & $\checkmark$ & $\checkmark$ & $\checkmark$ & & 9,930 . & 7 \\
\hline & $\checkmark$ & $\checkmark$ & & $\checkmark$ & & $\therefore$ & $\checkmark$ & $\checkmark$ & & 310,000 & 5 \\
\hline & & & & $\checkmark$ & & $\checkmark$ & $\checkmark$ & $\checkmark$ & $\checkmark$ & 475,000 & 5 \\
\hline & $\checkmark$ & & $\checkmark$ & $\checkmark$ & & & $\checkmark$ & $\checkmark$ & $\checkmark$ & 425,000 & 6 \\
\hline & & & $\checkmark$ & $\checkmark$ & & & $\checkmark$ & $\checkmark$ & $\checkmark$ & 856,750 & 5 \\
\hline TOTAI & & & & & & & & & & $2,340,480$ & \\
\hline
\end{tabular}

An appeal from one of the unsuccessful EOI applicants also exposed difficult issues concerning the interaction between the EOI process and merit appeals under the RIWI Act. Mr Barnetson had applied for $102,000 \mathrm{kl}$ to irrigate 6 hectares of mangoes. His licence application was refused on the grounds that 'it was unsuccessful through the Merit Selection Process and consequently the water resource has reached the sustainable limit'. ${ }^{384} \mathrm{Mr}$ Barnetson appealed from this refusal. The appeal was ultimately lost on technical grounds concerning the appellant's failure to show that he had legal access to the land in question. However, the Tribunal did note the difficulties it would have faced if the appeal had not been resolved on this basis:

There is an unresolved dilemma in how an appeal tribunal should treat an appeal on an application that has been refused in a competitive process of application for scarce water resources. It is not clear that a tribunal granting an appeal in such a situation would have the power to review other successful applications and deny them the grant of a licence. This issue may require the attention of Parliament. ${ }^{385}$

\footnotetext{
${ }^{382}$ Department of Water, above n 372; Marsden Jacobs Associated, 'Evaluation of mechanisms for releasing unallocated water in Western Australia - Part A: Selection of market instruments' (2010) 5-6, 9.

${ }^{383}$ Department of Water, above $\mathrm{n} 372,18$.

${ }^{384}$ Barnetson $v$ Water and Rivers Commission (Report of the Decision of the Appeal Tribunal, 13 February 2004) per Tribunal Member A Gardner.

385 Ibid.
} 
The Gingin case study illustrates that, while merit-selection has the benefit of at least trying to direct water to higher value uses, there are practical problems with seeking to rank potential licence applicants. The case study also illustrates the difficult issues raised by merits appeals under the RIWI Act following an EOI process. The latter problem could be solved by providing a proper legal basis in the water resources legislation for alternatives to the traditional licensing process, and clarity around related appeal rights. Provisions in the Water Management Act 2000 (NSW) provide one possible model. ${ }^{386}$

\section{Market-based mechanisms for release of groundwater in other jurisdictions}

Legislation in most other Australian jurisdictions authorise a range of approaches to groundwater allocation, including the use of market-based mechanisms. ${ }^{387}$ The following case study provides an example of one market-based mechanism: the use of auctions to allocate groundwater.

\section{Case Study: Auction of Water Licences in the Great Artesian Basin, NSW (2009) ${ }^{38}$}

Groundwater in the Great Artesian Basin became available for allocation due to water savings from the 'Cap and Pipe the Bores Program' and a policy decision to allocate $30 \%$ of saved water to new or existing users.

Under the Water Management Act 2000 (NSW), the Minister may declare, by order published in the Government Gazette, that the right to apply for a water licence is 'to be acquired by auction, tender or other means specified by the order' (s65).

In November 2008 the NSW Minister for Water, Hon. Phillip Costa MP, signed the Controlled Allocation of Access Licences Order for the NSW Great Artesian Basin Groundwater Sources.

The objectives of the auction were to:

- make access licences available to new or existing water users

- stimulate trade in the NSW Great Artesian Basin Groundwater Sources

- establish a market value for entitlements in the NSW Great Artesian Basin Groundwater Sources

- provide an equitable opportunity to potential purchasers of the water.

The auction was held in July 2009. All 24 access licences that were available for auction, which collectively authorised the extraction of $2,718 \mathrm{ML}$, were sold within 75 minutes.

\footnotetext{
${ }^{386}$ In NSW the Minister may, by order published in the Gazette, declare that the right to apply for an access licence for a specified water management area or water source is to be acquired by auction, tender or other means specified in the order. A person who fails to acquire such a right is unable to apply for a licence, so there is no question of appeal. However a person who is successful in acquiring a right to apply for an access licence and is subsequently refused that licence has a right of appeal. See Water Management Act 2000 (NSW) ss 65, 61(1)(c), 368.

${ }^{387}$ Gardner, Bartlett and Gray, above n 22, 464; Chung, above n 365, 283.

${ }^{388}$ Material for this case study is drawn from Tara Schalk, Christine Hill and Noel Flavel, 'NSW Great Artesian Basin Water Market Assessment Pre and Post Auction ' (Paper presented at the 54th Annual Conference of the Australian Agricultural and Resource Economics Society, 2010) and NSW Office of Water, 'NSW Great Artesian Basin Water Auction 2009: Final Report' (2010).
} 
A post-auction report suggested that $60 \%$ to $70 \%$ of the water purchased will be used to support tourism, and the balance to support intensive industries such as feed lotting.

The average price paid was $\$ 725 / \mathrm{ML}$. The auction revenue of $\$ 870,000$ was reinvested in the Cap and Pipe the Bores Program.

\section{Proposals for regulatory reform}

The 2013 Position Paper proposes that the new legislation will provide broad powers to allocate water:

It is proposed that the new legislation allow for unallocated water to be granted by various mechanisms, including FIFS [first-in, first served], competitive submission according to certain criteria which may not involve payment for the water, market mechanisms or other suitable means. The method of releasing unallocated water will vary across the state taking into account the resource characteristics, the level of demand, and community and industry requirements. Local advisory groups would play a role in determining suitable mechanisms.

This 'all of the above' approach to allocation mechanisms to allow for a flexible approach is difficult to criticise for an Act that is likely to be in place for decades across very different water resources. However, there remains a fundamental question posed by conditions in the South West: whether, in a drying climate and with increasing water demand, groundwater should continue to be free.

Certainly national policy principles would favour increased use of market mechanisms such as auctions. Such an approach is also more likely than the first-in, first-served approach to allocate water to its highest use: as the Department has noted, 'preparedness to pay is the best (albeit imperfect) guide to productivity'. ${ }^{389}$ By putting a price on water, the use of market-based mechanisms would also provide a signal of water scarcity and promote more efficient water use.

Market-based mechanisms could be used for reserved water. Where auctions are not practical, such as where the Water Corporation would be the only bidder for water from a public water supply reserve or a local government the only bidder for water from a public open space reserve, direct sale could be used. ${ }^{390}$ This would help put a value on alternatives to groundwater, such as use of managed aquifer recharge to store stormwater or treated wastewater.

\section{Law reform recommendation: Allocation of groundwater through market-based} mechanisms

The new water resource management legislation should provide a firm legal basis for the release of unallocated water through a range of mechanisms, including market-based mechanisms such as auctions. Market-based mechanisms should be considered the default approach for heavily allocated groundwater resources, including where water has been reserved for particular uses.

This raises the question of what should be done with revenue from the use of auctions and other market-based mechanisms. The Water Reform Implementation Committee recommended that this

\footnotetext{
${ }^{389}$ Department of Water, above n 372, 23.

${ }^{390}$ On different options for market-based release, including direct sale, see Marsden Jacobs Associated, above n 381.
} 
revenue be directed to water resource management. ${ }^{391}$ As we have seen, this approach was adopted in the Great Artesian Basin case study. The advantages of this approach are that it would build support for the introduction of market-based mechanisms and provide much-needed funding for water resource management.

\section{Law reform recommendation: Use of revenue from groundwater allocation}

The revenue from the release of groundwater through auctions and other market-based mechanisms should be directed to water resource management.

\subsection{Trading groundwater}

\section{Trading groundwater in the South West: the experience to date}

As we outlined in Chapter 1, the RIWI Act was amended in 2001 to provide for trade in water entitlements. Trade can take place by transferring the whole of a licence to another person; transferring part of the volumetric water entitlement under a licence to another person; or by entering into a short-term lease of water from a licence-holder.

There have been a number of trades since 2001. Table 16 provides an overview of groundwater trade in the South West since 2007, and Appendices G and H provide more detail. Unfortunately, the data does not identify what proportion of the transfers were trades of water separate from land, as opposed to the more traditional transfer of a water licence on the sale of land. However, the figures do suggest that there is an increasing trade in groundwater in the South West over and above trade associated with the sale of land.

Table 16: South West groundwater trade 2007-08 to 2012-13

\begin{tabular}{|c|c|c|c|c|}
\hline Year & $\begin{array}{c}\text { Number of } \\
\text { transfers }\end{array}$ & $\begin{array}{c}\text { Volume of } \\
\text { transfers } \\
\text { (ML) }\end{array}$ & Number of leases & $\begin{array}{c}\text { Volume of leases } \\
\text { (ML) }\end{array}$ \\
\hline 2007-08 & 14 & 486 & 1 & 33 \\
\hline 2008-09 & 62 & 2115 & 11 & 292 \\
\hline 2009-10 & 73 & 10218 & 7 & 182 \\
\hline 2010-11 & 65 & 16632 & 9 & 4551 \\
\hline 2011-12 & 60 & 6455 & 27 & 4166 \\
\hline $2012-13$ & 103 & 33276 & 44 & 5739 \\
\hline TOTAL & 377 & 69182 & 99 & 14963 \\
\hline
\end{tabular}

\footnotetext{
${ }^{391}$ Water Reform Implementation Committee, above n 115, 12. See also the government response of February 2007, which appeared to accept the recommendation, at least in respect of revenue from tenders: Government of Western Australia, 'Government Response to a Blueprint for Water Reform in Western Australia' (2007), 9.
} 
In a detailed study of groundwater trading in the Gnangara system, Skurray, Randit and Pannell identified a number of impediments to groundwater trade. ${ }^{392}$ These include:

- the 'weakness of property rights to groundwater use', including their time-limited nature and the power of the Minister to amend a licence;

- the 'licence eligibility' requirement in the RIWI Act, which will ordinarily mean that the purchaser must usually own or occupy the land on which the water is to be used;

- the transactions costs associated with a detailed assessment by the Department of each proposed trade; and

- the lack of published information on market prices and potential sellers.

\section{Groundwater trading in other jurisdictions}

The following case study provides an example of groundwater trading in New South Wales, which has the highest volume of groundwater trade in Australia.

Interstate Case Study: Lower Murrumbidgee Groundwater Sources, South Western NSW

Of all Australian jurisdictions, NSW has the greatest activity in temporary and permanent groundwater trading. The majority of the trade, some $75 \%$ by volume, occurs in the Lower Murrumbidgee Deep, Lower Murray and Lower Lachlan aquifers.

This trade occurs under the framework of the Water Management Act 2000 (NSW) and the water planning and other legislative instruments made under that Act. For the Lower Murrumbidgee this includes the Water Sharing Plan for the Lower Murrumbidgee Groundwater Sources 2003 (WSP Lower Murrumbidgee 2003). It is supported by the gazetted Implementation Program for the major inland alluvial groundwater Water Sharing Plans February 2010, whichsets milestones for delivery on the Plan's objectives. Although there was some trade before the commencement of the plan, the WSP has enabled permanent trading of water entitlements.

The Lower Murrumbidgee Deep Groundwater Source (as distinct from the shallow groundwater sources where there has not been much trading) has a system area of $31,372 \mathrm{~km}^{2}$, a system thickness of 100 to $300 \mathrm{~m}$, and an annual recharge of $335000 \mathrm{ML}$. The extraction limit varies each year but averages $270000 \mathrm{ML}$ plus water made available under basic landholder water rights and under supplementary water access licences. Planned environmental water (i.e. water reserved for environmental outcomes) is $65,000 \mathrm{ML} / \mathrm{yr}$. Approximately 340 production bores access this groundwater source, using the water for irrigation and town supply with access permitted under various licences; namely, local water utility (2210 ML), domestic and stock (324 ML), aquifer $(267,777 \mathrm{ML})$ and supplementary water access licences $(41,196 \mathrm{ML})$. All bores are metered.

The Act's provisions set the overarching rules for water trades or dealings with aquifer access licences and the WSP Lower Murrumbidgee 2003 provides more specific rules for the particular water source, together providing clear processes for managing aquifer entitlements with a high degree of certainty.

392 Skurray, Pandit and Pannell, above n 359, 162. 
For example, the access licence dealing rules under the WSP Lower Murrumbidgee 2003 impose various constraints on dealings or trades within a groundwater source; e.g. relating to conversion of an access licence category, water allocation assignments between water sources, and to interstate access licence transfer or assignment of water allocations. They allow for permanent trades that include changes to access licence shares or to change an extraction location, and temporary trades that include changes in the volume of water held in an account.

All dealings must be consistent with the Plan's rules, including local management area rules, which have been developed to manage localised drawdowns on groundwater levels, and which do not permit trading outside or between local management areas.

There are also requirements for some level of hydrogeological assessment of the impacts of proposed trading applications. These are carried out by the NSW Office of Water (NOW) with a fee payable by the applicant as determined by the State's economic regulator IPART. The Office is also responsible for monitoring groundwater levels of 246 bores at 108 sites for deep and shallow groundwater sources.

Data on the types, numbers and trade volume, in addition to other licensing information is publicly available at http://registers.water.nsw.gov.au. A small sample is set out below confirming that the Lower Murrumbidgee Deep Groundwater Source has the highest level of groundwater trading of any of these inland alluvial groundwater sources.

\begin{tabular}{||r|r|r|r|r|}
\hline Year & \multicolumn{2}{|c|}{$\begin{array}{c}\text { Temporary Dealings } \\
\text { (Assignment of water allocations } \\
\text { between access licences s71T } \\
\text { WMA) }\end{array}$} & \multicolumn{2}{c|}{$\begin{array}{c}\text { Permanent Dealings } \\
\text { (Assignment of rights under } \\
\text { access licence s71Q QMA) }\end{array}$} \\
\hline & Number & Volume (ML) & Number & Shares \\
\hline $2007-08$ & 190 & 54,977 & 8 & 1,523 \\
\hline $2008-09$ & 291 & 101,098 & 16 & 5,610 \\
\hline $2009-10$ & 222 & 83,051 & 9 & 2,058 \\
\hline $2010-11$ & 35 & 13,086 & 5 & 1,275 \\
\hline $2011-12$ & 41 & 12,751 & 3 & 2,756 \\
\hline
\end{tabular}

Proposals for regulatory reform

The 2013 Position Paper acknowledges that 'current arrangements do not foster efficient and effective trade' and proposes four reforms:

- to simplify the assessment process, so that applications for trades that represent a low risk to the water resource, other water users or the environment will not be required to undergo the full assessment process;

- to include generic, state-wide trading rules in the new legislation, such as a rule that requires metering to be in place before trading can occur; and

- to make traded volumes and prices publicly available to ensure that buyers and sellers have sufficient information to make informed decisions 
- to provide prospective buyers with limited contact details of licensees to facilitate contact between buyers and sellers. ${ }^{393}$

These measures, together with the proposal for perpetual water entitlements, go a long way to addressing the barriers to groundwater trade identified by Skurray, Randit and Pannell. Clearly, much will depend on the design of trading rules, whether they are state-wide rules in the legislation or more area-specific rules in statutory water plans. ${ }^{394}$ However these proposals would be a good start in reducing trading transaction costs and bringing buyers and sellers together.

One issue that isn't addressed in the 2013 Position Paper is whether the 'landholder licence eligibility' requirement will be retained in the new Act. This requirement seeks to ensure that a person who obtains a water entitlement has the capacity to make beneficial use of the water right; that is, the person has legal access to the land from which the water will be taken and to the land where the water will be used. This restriction was included to avoid speculative acquisition of water entitlements, ${ }^{395}$ but has the collateral effect of excluding other prospective water purchasers, such as businesses that wish to acquire a portfolio of water entitlements for leasing, or investors acquiring a water entitlement before acquiring land title, ${ }^{396}$ or non-government 'water trusts' that wish to purchase water entitlements to maintain environmental values. ${ }^{397}$ While there are other policy arrangements to address the second and third situations, the landholder eligibility criterion for licensees does preclude the investment in water entitlements for leasing purposes, which could be a beneficial arrangement in a developed area with an operating water market that would likely regulate excessively speculative investment in water entitlements. On the other hand, in an undeveloped area with no operating water market, there may be merit in retaining the landholder eligibility requirement with a beneficial use assessment to dampen speculative investment in water entitlements, especially if water entitlements are granted at no cost. ${ }^{398}$

One final point to note is the important relationship between trading and the use of market based mechanisms to release unallocated water. In areas that are not fully allocated it

\footnotetext{
${ }^{393}$ Department of Water, above n 69, 11-12.

${ }^{394}$ For example the rule that groundwater cannot be traded between management sub-areas has been a substantial constraint on trade in the Gnangara system: Skurray, Pandit and Pannell, above n 162, 16.

${ }^{395}$ Government of Western Australia, above $n$ 80, 79 ('The list of people eligible to hold licenses has been carefully drafted to avoid speculation in licences once trading has been introduced').

${ }^{396}$ James H. Skurray, Ram Pandit and David J. Pannell, 'Institutional impediments to groundwater trading: the case of the Gnangara groundwater system of Western Australia' (2013) 56(7) Journal of Environmental Planning and

Management 1, p13. This issue is effectively solved in Western Australia by Rights in Water and Irrigation Act 1914 (WA) Schedule 1, cl.9.

${ }^{397}$ Water trusts have a long history in the Western United States: Mary Ann King, 'Getting Our Feet Wet: An Introduction to Water Trusts' (2004) 28 Harvard Environmental Law Journal. In Australia, the Environmental Water Trust has been established 'as a national independent non-government charitable organisation to facilitate investment in the long term environmental health of Australia's rivers and wetlands': <http://environmentalwatertrust.org.au>.

${ }^{398}$ By way of comparison, there are case examples of where large speculative water licence applications were refused because it was apparent that the applicant could not make beneficial use of the amount of water applied for: De Tournouer v Chief Executive, Department of Environment and Resource Management [2009] QCA 395; Niebieski Zamek Pty Ltd v Southern Rural Water (No 2) [2003] VCAT 223.
} 
would not make much sense to pay for a water trade when you can apply for grant of unallocated water for nothing. If the alternative is to purchase water in an auction, however, there is a greater incentive to trade. Thus the recommendations we have made above concerning increased use of market-based mechanisms to release unallocated water would also support greater trading of water entitlements.

\section{Law Reform Recommendations: Water Trading}

The legislation should be designed to facilitate trade in groundwater entitlements, including through implementation of the reforms outlined in the 2013 Position Paper. The legislation should include the capacity to remove the requirement that a purchaser of an entitlement must be an owner or occupier of the land from which the water will be taken. 


\section{Applying the reforms to groundwater resources in the South West}

The National Water Initiative model, built around the concept of water users holding tradeable shares to a sustainable consumptive pool, is sometimes criticised as an Eastern States invention that works for surface water but isn't suitable for groundwater resources. To some extent this ignores the fact that there are substantial groundwater resources in the Eastern States, and that many of these resources are already subject to the National Water Initiative model. However, it is true that there are issues that need to be addressed in applying this model to groundwater resources, and that the model may not be appropriate for all groundwater resources in the South West. We address the key implementation issues below.

\subsection{Defining the consumptive pool in the face of uncertainty}

One important feature of groundwater management is the uncertainty that can be associated with groundwater resources. This may include uncertainty as to physical characteristics of an aquifer (e.g. extent and storage volume), groundwater hydrology (e.g. connections with other aquifers and surface waters) and ecosystem processes supported by groundwater. ${ }^{399}$ This uncertainty is already a challenge for groundwater managers in the South West. There is the potential for statutory allocation plans and share-based entitlements to lead to additional difficulties, if they are developed for poorly understood groundwater resources or are badly designed.

One problem is that the volume of water that is allocated to water entitlements will tend to be unreliable in poorly understood systems. Consider the history of groundwater allocations in the Gingin Groundwater Area. As is clear from Table 17, there have been significant changes in allocation limits over the last two decades, in part due to a drying climate. ${ }^{400}$ However, this has not translated into variations in the volume of water that may be taken by individual licensees, because the amount of water that can be taken is specified in each licence and was not varied. ${ }^{401}$ Contrast this with a share entitlement system, in which the volume of water that can be accessed varies with changes in the consumptive pool. It is likely that under such a system there would have been considerable variation in the amount of water that could be taken by users holding share entitlements in the Gingin superficial aquifers.

\footnotetext{
${ }^{399}$ Rebecca Nelson and Meg Casey, 'Taking Policy from Paper to the Pump: Lessons on Effective and Flexible Groundwater Policy and Management from the Western US and Australia' (2013) 8; Rebecca Nelson, 'Groundwater: Hidden Promise, Hidden Perils' (Committee for Economic Development of Australia, 2012) 9; National Water Commission, above n 18, 9.

400 Department of Water, above n 373, 20 ('To set allocation limits we assumed a 15 per cent reduction in average annual recharge by 2020 . This is consistent with dry climate projections for the south-west of Western Australia').

${ }^{401}$ As we have seen, licences can be individually varied to entitlements within allocation limits, but this is difficult and until has generally been unnecessary for Gingin's superficial aquifers as there has been limited over-allocation. Of the Gingin superficial aquifer management areas, only the Red Gully subarea is classified as over-allocated: see Appendix E.
} 
Table 17: Allocation Limits for Gingin Superficial Aquifers (1993-2014) ${ }^{402}$

\begin{tabular}{|l|l|l|l|}
\hline Groundwater resource & \multicolumn{1}{|c|}{$\begin{array}{l}1993 \text { allocation } \\
\text { limit (ML/yr) }\end{array}$} & $\begin{array}{l}\text { 2001 allocation limit } \\
\text { (MLlyr, \% change) }\end{array}$ & $\begin{array}{l}\text { 2014 allocation limit } \\
\text { (ML/yr, \% change) }\end{array}$ \\
\hline Bermullah Plain North & 16,020 & $12,800(-20 \%)$ & $6,500(-49 \%)$ \\
\hline Eclipse Hill & 630 & $1,400(+122 \%)$ & $1,050(-25 \%)$ \\
\hline Karakin Lakes & 30,130 & $24,000(-20 \%)$ & $17,000(-29 \%)$ \\
\hline Lancelin & 28,420 & $27,400(-4 \%)$ & $21,000(-23 \%)$ \\
\hline Namming Lake & 15,320 & $13,000(-15 \%)$ & $10,500(-19 \%)$ \\
\hline North Moore River Park & 12,140 & $12,900(+6 \%)$ & $12,900(0 \%)$ \\
\hline Red Gully & $\mathrm{NA}$ & 1,000 & $750(-25 \%)$ \\
\hline Seabird & 29,180 & $22,100(-24 \%)$ & $17,000(-23 \%)$ \\
\hline South Moore River Park & 11,890 & $7,500(-37 \%)$ & $7,500(0 \%)$ \\
\hline Wedge Island & 67,030 & $78,700(+17 \%)$ & $58,500(-26 \%)$ \\
\hline
\end{tabular}

As this example illustrates, it may make sense, for poorly understood groundwater systems that are not highly allocated on current understanding, to set conservative allocation limits and continue with traditional, short-term licences. This approach, which accepts the value of the share entitlement model but also acknowledges that it may not be immediately applicable in all areas, is consistent with the views expressed by the State Government in its 2013 Position Paper. ${ }^{403}$

Where knowledge of groundwater systems is sufficient to allow flexible water entitlements to be introduced, they should still be designed in a way that anticipates improvements in knowledge. For example, it is possible that adjustments may be made to the boundaries of groundwater management units as the extent of an aquifer becomes better understood. It has been suggested that it will be easier to cope with this under a system that specifies entitlements as units, rather than as a proportional share of a consumptive pool. If entitlements are specified as a proportional share then a boundary change would mean that every entitlement would have to be amended, rather than just those entitlements moving from one management area to another. ${ }^{404}$

\subsection{Maintaining incentives for groundwater exploration}

There is another reason why the model we have recommended in the preceding chapters may not be appropriate for poorly understood aquifers; namely, that it may discourage exploration for groundwater. While the current regulatory framework does not explicitly address the issue of whether priority access should be granted to applicants who have identified a groundwater resource through exploration activity, the 'first in, first served' licensing approach does tend to have this effect. This is because an application for a licence to take groundwater in a poorly understood

\footnotetext{
${ }^{402}$ Figures drawn from Water and Rivers Commission, above n 223 and Department of Water, above $\mathrm{n} 373$. While the latter is a draft plan, the authors understand that the allocation limits in the plan are currently in use.

${ }^{403}$ Department of Water, above n 70, 18.

${ }^{404}$ Young, above n 355, 30.
} 
system will need to be supported by a hydrogeological report obtained following exploratory drilling and test pumping. ${ }^{405}$ The owner of such a report will be able to be the 'first in' with a licence application that meets this requirement. Thus, while the RIWI Act is silent on the question of whether 'groundwater explorers' will be able to access the resource they identify, they do have a reasonable degree of security in practice.

A model built around the recommendations in chapters 5 to 7 of this report may not provide the same incentives for groundwater exploration, for the following reasons.

- Statutory planning: If a 'groundwater explorer' does prove up the presence of more groundwater an allocation limit may need to be amended to allow that person to access the water. It would take longer to do this under the statutory allocation plan model than under the current model, which has no statutory allocation limit.

- Share-based entitlements: If an allocation limit is increased, existing holders of sharebased entitlements expressed as a percentage of the consumptive pool may feel that they should share in the benefit of this increase. If this were allowed the groundwater explorer would only be able to access part of the water it had identified. ${ }^{406}$ Expressing the share entitlements as units with a nominal volume should overcome this problem.

- Market-based instruments: If the newly identified water, or the portion of it available for allocation, is released through an auction another bidder could prevent the 'groundwater explorer' from accessing the groundwater they identified. To avoid this risk, it would be better to allocate a right to explore for water by a market process, if the resource potential justifies the pricing.

For these reasons, it may be more appropriate to use the traditional licensing model while there is scope for groundwater exploration to identify additional resources. Statutory water plans, sharebased entitlements and market-based releases would only be introduced when the resource is well understood. Alternatively, the more sophisticated design of a statutory water plan may be able to accommodate procedures for efficient and effective water exploration and entitlement allocation with a consumptive pool methodology. This would require greater public investment in plan making but it may also provide for better water resource management.

In any case, a more formal recognition of groundwater exploration may also be appropriate within the traditional licensing framework. While groundwater explorers have a reasonable level of security in practice, this security would be increased if the Minister (or delegate) were required to take into account, in deciding whether an applicant should be granted a licence, any work undertaken by the applicant to explore for the groundwater resource. ${ }^{407}$

\footnotetext{
${ }^{405}$ Department of Water, above $\mathrm{n} 84$, iii.

${ }^{406}$ It could be argued that there are situations in which it would be not be appropriate, given the public nature of groundwater resources, for the 'groundwater explorer' to be entitled to all of the water it identifies.

${ }^{407}$ Section 26D licences are often referred to as 'exploration licences' (e.g. Department of Water, 'Cockburn Groundwater Area Water Management Plan' (Government of Western Australia, 2007) 35). However, the exploration undertaken under these licences is not identified by the RIWI Act as a consideration relevant to the grant of the licence: Rights in Water and Irrigation Act 1914 (WA) sch 1 cl 7; compare Mining Act 1978 (WA) s75(7).
} 


\subsection{Providing sufficient reliability for water users}

By replacing short term licences with perpetual water entitlements, the National Water Initiative model gives a great deal more certainty to water users as to the term of their entitlement. But can this system provide sufficient reliability as to the volume of groundwater that can be accessed? Subject to the caveats expressed above about introducing share-based entitlements to poorly understood groundwater systems, the National Water Initiative model certainly has the capacity, through the design of statutory water allocation plans, to find the right balance between reliability of individual water entitlements and flexibility to manage the overall level of extraction. This trade-off between flexibility and reliability is illustrated in Figure 22, using the examples of rules for consumptive pool determinations considered earlier in this report. Figure 22 indicates, for example, that a specified consumptive pool that is fixed for the life of a plan provides limited flexibility to manage the total level of extraction to climatic conditions but high reliability for entitlement holders. At the other extreme, an annual discretionary determination of the consumptive pool offers great flexibility but limited reliability. The other rules fall somewhere between these two extremes.

Figure 22: Trade-off between flexibility and reliability in rules for determining consumptive pools
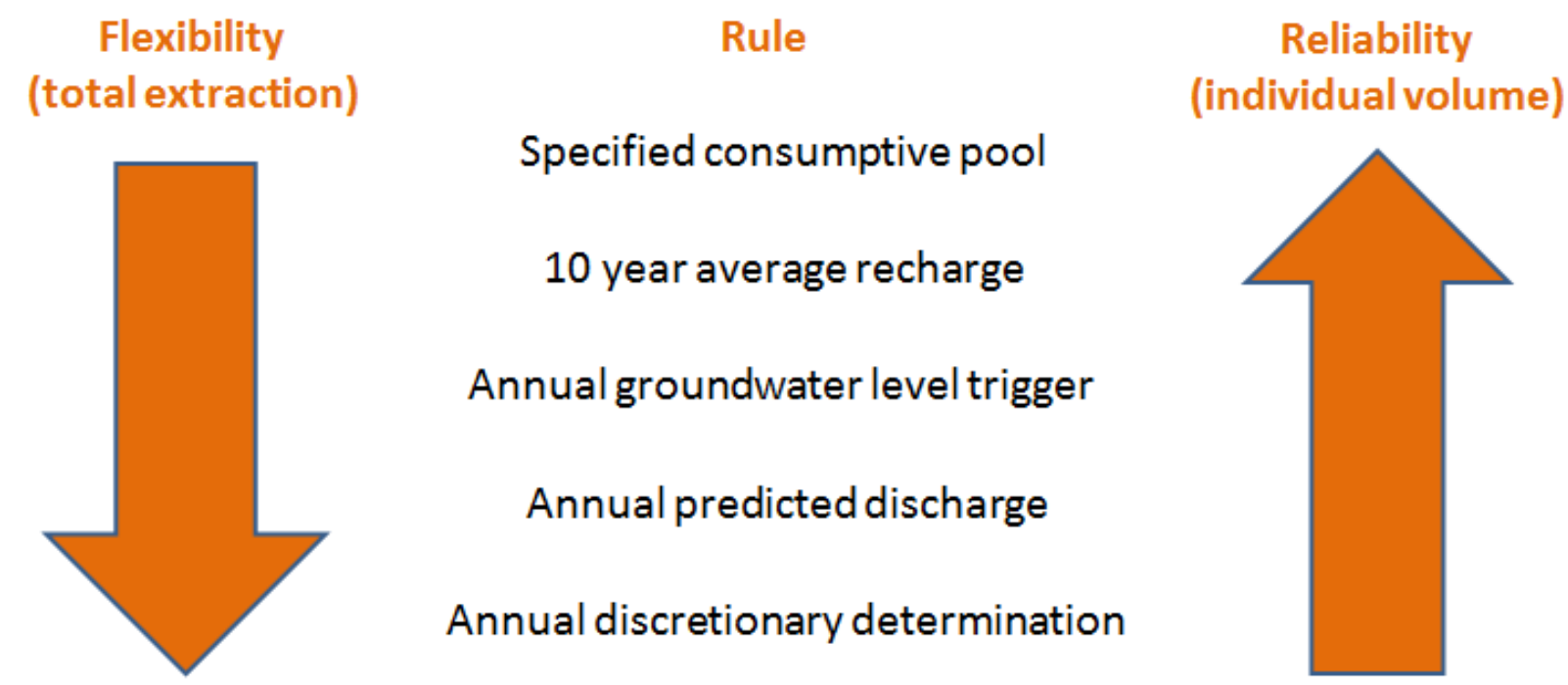

Even where there is considerable flexibility to vary consumptive pools, it is possible to offer high levels of reliability to some water users in the form of high security entitlements. The following case study provides an example of how this can be done.

\section{Case Study: Tindall Limestone Aquifer, Northern Territory ${ }^{408}$}

The Northern Territory's Katherine River relies on groundwater discharge from the Tindall Aquifer to maintain flow all year round. An important management objective for this aquifer is to maintain that flow. To that end, the Water Allocation Plan for the aquifer has made provision for three scenarios:

- During very dry years, $87 \%$ of the groundwater discharging into the Katherine River will be reserved for environmental and other river-based public benefit outcomes whilst $13 \%$ is

\footnotetext{
${ }^{408}$ Department of Natural Resources, above $\mathrm{n}$ 307. The authors thank Kate Gole from the National Water Commission for bringing this management plan to their attention.
} 


\section{available for extraction.}

- During dry years, $80 \%$ of the groundwater discharging into the Katherine River will be reserved for environmental and other river-based public benefit outcomes, whilst $20 \%$ is available for extraction.

- During normal to wet years, $70 \%$ of the groundwater discharging into the Katherine River will be reserved for environmental and other river-based public benefit outcomes whilst $30 \%$ is available for extraction.

The Plan provides for four categories of licence: total security, high security, medium security and low security. Where the consumptive pool in any year is less than the sum of nominal licence volumes the announced allocation will be determined in the following way:

- Reductions are placed on low security licences first;

- Once low security licences have been reduced to zero, medium security licences will be reduced;

- Once medium security licences have been reduced to zero, high security licences will be reduced.

The Plan estimates the reliability of each category of licence, based on historic rainfall and flow data in the Katherine River from 1957 to 2006, as follows:

- Total security - licence holders can expect access to their maximum annual licence volume in all but extreme circumstances.

- High security - licence holders can expect access to their maximum annual licence volume in about $70 \%$ of years.

- Medium security - licence holders can expect access to their maximum annual licence volume in about $30 \%$ of years.

- Low security - licence holders can expect to access to their maximum annual licence volume in about $15 \%$ of years.

It is possible for the primary legislation to establish different classes of entitlement and the relative priority of those entitlements, including for groundwater. For example, the Water Management Act 2000 (NSW) provides that, subject to different priorities being established by a statutory allocation plan, local water utility access licences, major utility access licences and domestic and stock access licences have priority over all other access licences. ${ }^{409}$

\subsection{Managing the transition to the new system}

A final implementation issue for the South West is how existing licences will be converted to the new share-based entitlements. In areas that are not over-allocated, the process should be relatively simple. Upon the making of a statutory water allocation plan, and either through that plan or a separate instrument, existing licence holders would have their licences replaced with a share entitlement that authorises access to an equivalent volume of water. In most cases this should not raise concerns about unfairness to the licence holder. Some concerns may be raised in cases where the rules in the new statutory allocation plan could lead to reduced reliability in the volume of

\footnotetext{
${ }^{409}$ Water Management Act 2000 (NSW) s 58. Regulations also create the licence categories of 'aquifer (high security) access licence' and 'aquifer (general security) access licence': Water Management (General) Regulation 2011 (NSW), reg 4.
} 
water that may be accessed. There are likely to be techniques that can be used to address these concerns. For example, high security entitlements could be granted to existing licensees on transition. ${ }^{410}$

In areas that are over-allocated, and therefore where an entitlement to a share of a sustainable consumptive pool may be less than the volume of water available under the old licence, more difficult questions arise concerning the reductions of entitlements, including:

(i) how to set the benchmarks of current entitlements from which reductions are to be made,

(ii) what criteria should apply in determining the reduction of entitlements, and

(iii) should compensation be payable?

We do not have concluded views in answer to these questions but identify the following issues to address. For question (i), should reductions be made solely from the level of legal entitlement of existing licensees or should the history of extraction be taken into account or even given greatest weight in determining the existing level of entitlement? For question (ii), should reductions from the benchmark levels be proportional without regard to the efficiency or purpose of use? If entitlements with different levels of security are to be issued on transition, should such grants be issued by administrative determination based on criteria to be defined in the plan or should they be auctioned? For question (iii), on balance, we do not favour compensation being payable. No other State or Territory's water management legislation provides for compensation for reductions in water volumes associated with the conversion of licences to share entitlements. ${ }^{411}$ However, the transitions in other States occurred from statutory foundations that did not provide for compensation on reduction of entitlements. Western Australia has already made one law reform transition in 2001 to implement pre-National Water Initiative water policy principles and Parliament chose then to provide compensation for entitlement reductions in certain circumstances. ${ }^{412}$ Perhaps those provisions should apply on transition from the existing form of take and use licences to NWI entitlements.

There are also techniques that could be considered to ease the transition of over-allocated areas to NWI entitlements. One technique that can be used is to issue supplementary entitlements which phase out over several years. New South Wales has used this approach for groundwater systems, including in the Namoi Catchment. ${ }^{413}$ Statutory water allocation plans provide the detail of how these supplementary entitlements are to be allocated and phased out. For example, a formula in the plan may ensure supplementary entitlements are sufficient in the first year to provide a 'top up' to historic levels of extraction for each entitlement holder (established by an average of their metered water use over several years), but also provide that the volume of water that will be made available to supplementary licences will be reduced gradually to zero over the life of the plan. ${ }^{414}$

Another technique, which can be used where there is significant over-allocation but no overextraction, is to allow over-allocation to continue as long as extraction remains within sustainable limits. For example, in one Victorian groundwater system nominal entitlements were 60GL/yr but

\footnotetext{
${ }^{410}$ e.g Department of Natural Resources, above n 307, 72-73.

${ }^{411}$ Gardner, Bartlett and Gray, above n 22, 298.

${ }^{412}$ Rights in Water and Irrigation Act 1914 (WA) Schedule 1, cl 39.

${ }^{413}$ Water Management Act 2000 (NSW) s 70; Hartley, above n 356, 106.

${ }^{414}$ Water Sharing Plan for the Upper and Lower Namoi Groundwater Sources 2003 (NSW) SS25D, 25E.
} 
actual use averaged only $28 \mathrm{GL} / \mathrm{yr} .{ }^{415}$ The Plan sought to maintain groundwater levels by providing for a reduced allocation (50\% against nominal entitlements) where the 5 year average of groundwater extraction exceeded $30 \mathrm{GL} / \mathrm{yr} .{ }^{416}$ This rule guarded against a collective change in behaviour by entitlement holders to extract a greater proportion of their nominal entitlements.

One final transitional issue for water allocation planning is the capacity of the Minister to adjust landholder and licence entitlements to deal with the stresses of localised over-allocation in the absence of making a general statutory water allocation plan for the management area. These could be situations of coastal saline intrusion (e.g. parts of Geographe Bay) or water quality impacts from intensive irrigation overlying shallow groundwater (e.g. Myalup); situations that may be particularly impacted by the effects of a drying climate. We suggest the legislation should empower the Minister to make plans of local application through an expedited process: a Minister's Plan. The Position Paper does not discuss how localised situations would be addressed. Our consultations revealed that the Department's current method of dealing with such situations is to approach relevant licensees individually and negotiate adjustments to individual licences to address a collective issue. The potential problems of this method are explained in section 6.2 above. We recommend that the legislation authorise the Department to prepare a plan for an area and purposes to be defined by the plan, using transparent public process concluding with the power of the Minister to adopt the plan by notice in the Government Gazette. A Minister's Plan should be authorised to deal with any matters that a full statutory water allocation plan can deal with and have binding legal effect on any person exercising powers or rights under the legislation. A Minister's Plan should be subject to any provision of a general statutory water allocation plan.

\subsection{Using groundwater as a "drought reserve"}

As the Katherine River case study illustrates, it may be necessary to reduce groundwater extraction in dry years in order to meet environmental or other public benefit objectives. However, there may be capacity in some groundwater systems - particularly deeper, more confined aquifers with large storage - to overdraw in some years and compensate for this by reduced extraction in other years. ${ }^{417}$ This is an important means of reducing vulnerability to water shortages in areas experiencing increased frequency and severity of droughts due to climate change. ${ }^{418}$ Given predictions of a continuing drying trend for the South West, the new water resource management legislation should ensure that groundwater can be made available, where it is appropriate to do so, as a 'drought reserve'.

Before we consider what new legislation could do to address this question, let us consider a case study of how groundwater has been used as a 'drought reserve' for public water supply under the existing regulatory framework.

\footnotetext{
${ }^{415}$ Government of Victoria, above n 312, 4.

416 Ibid 8.

${ }^{417}$ GHD et al, above n 14, x.

${ }^{418}$ Richard G. Taylor et al, 'Ground water and climate change' (2012) 3(4) Nature Climate Change 322, 326; Ruth Langridge, 'Confronting Drought: Water Supply Planning and the Establishment of a Strategic Groundwater Reserve' (2009) 12 University of Denver Water Law Review 295.
} 


\section{Case Study: Groundwater as a drought reserve for public water supply in the South West}

As we have seen, groundwater is an important source of water for the Integrated Water Supply Scheme (IWSS) that services much of the South West. The Water Corporation has been granted a number of licences to draw groundwater from the Gnangara and Jandakot groundwater systems for use in the IWSS. This includes extraction from shallow superficial aquifers and from the deeper, more confined Leederville and Yarragadee aquifers.

From 2002, the amount of groundwater the Water Corporation could extract for the IWSS was determined using the Variable Groundwater Abstraction Rule (VGAR), under which the quantity of authorised extraction for the Integrated Water Supply System in each financial year is inversely proportional to dam storage at its peak in October of that year (Figure 23). ${ }^{419}$ The VGAR was originally developed on the basis that average sustainable groundwater use for the IWSS was $135 \mathrm{GL} / \mathrm{yr} .{ }^{420}$ It was clearly anticipated that extraction would be above this figure in some years and below it in others, allowing groundwater to operate as a 'drought reserve' in dry years and to be replenished in wet years.

From 2008-09, the VGAR was modified to indicate that 120GL/yr was the new 'average sustainable abstraction target'. ${ }^{421}$ The reduction of this figure from $135 \mathrm{GL} / \mathrm{yr}$ to $120 \mathrm{GL} / \mathrm{yr}$ was the main measure identified in the Gnangara Allocation Plan to address over-allocation. ${ }^{422}$ However, the design of the new rule was not well suited to achieving lower abstraction for the IWSS, given that the relationship between dam storage and abstraction was not changed (Figure 24). The only change of substance introduced by the new VGAR was that additional conditions were to be satisfied before abstraction above $145 \mathrm{GL}$ would be authorised. These conditions included a requirement that all possible efforts had been made to secure alternative water supplies and that demand management measures were in place. ${ }^{423}$

In 2012-13, following a series of years of extraction above the target, the VGAR was abandoned. The Department explained the reasons for this as follows:

The [Variable Groundwater Extraction Rule], which uses groundwater to 'buffer' dry years, is only effective to manage variation around a steady average rainfall. In a declining rainfall trend it results in sustained high groundwater abstraction, compounding the effects of low recharge on the groundwater system. ${ }^{424}$

In place of the VGAR, the Department announced a stricter policy requirement for a five year average abstraction of $110 \mathrm{GL}$ (from existing bores). ${ }^{425}$ This approach is better suited to ensuring that an average sustainable abstraction target is achieved.

\footnotetext{
${ }^{419}$ Department of Water, 'Gnangara Groundwater Areas Allocation Plan', above n 39, 88.

420 Ibid.

421 Ibid 57.

422 Ibid.

423 Ibid.

${ }^{424}$ Department of Water, above $\mathrm{n} 166,24$.

${ }^{425}$ Department of Water, above $n$ 166, 12. This requirement coincided with the first stage of the Binningup desalination plant becoming fully operational.
} 


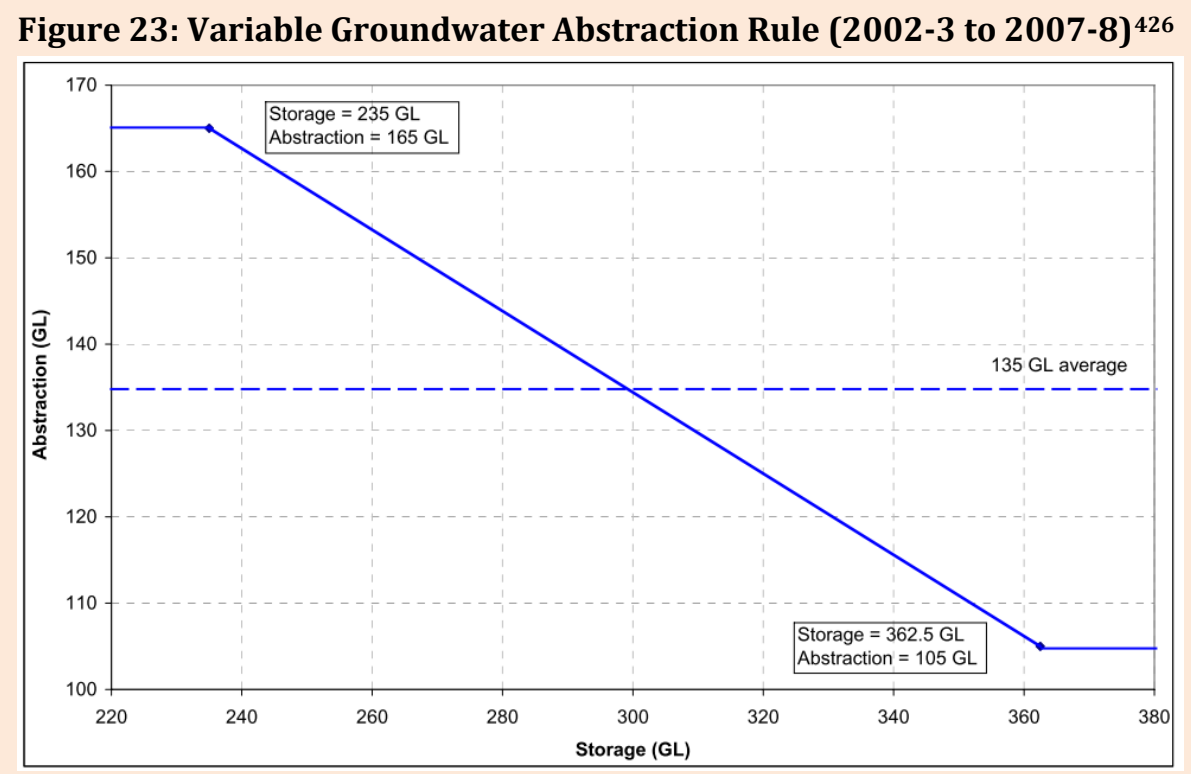

Figure 24: Variable Groundwater Abstraction Rule (2008-9 to 2011-12) ${ }^{427}$

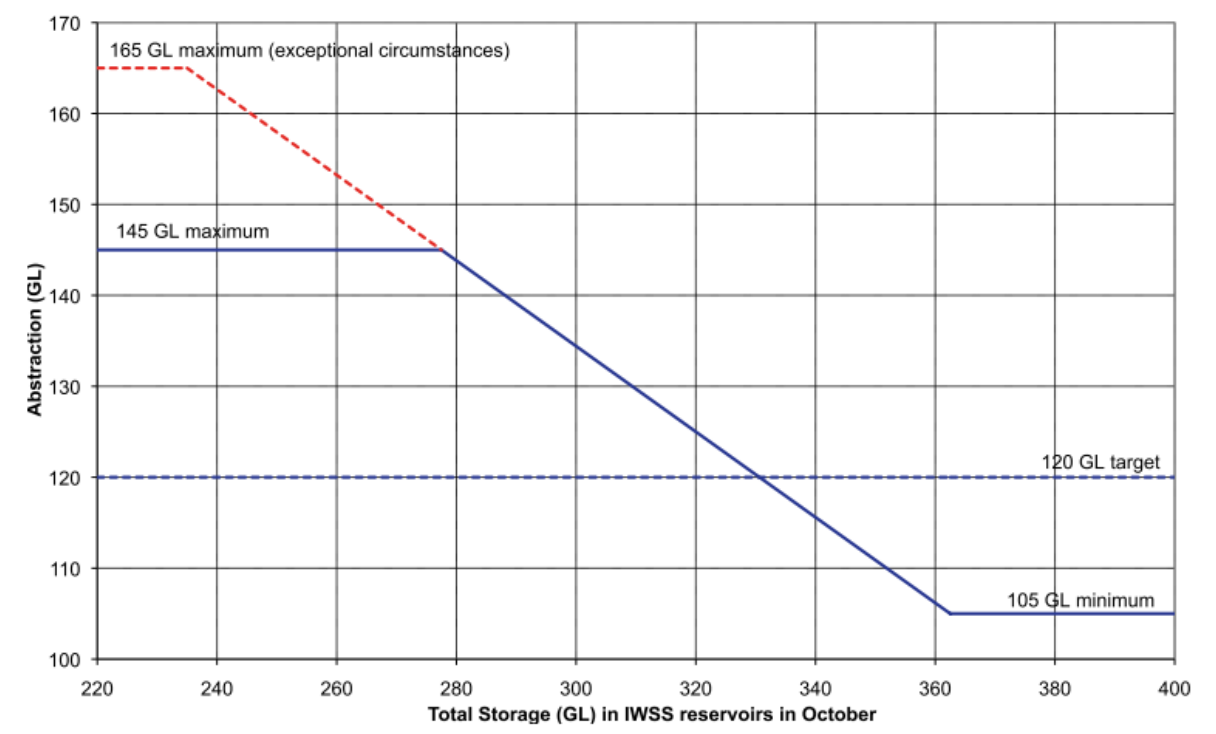

One remaining difficulty may be the lack of an effective legal mechanism to enforce the new rule. To date the main instrument governing the Water Corporation's groundwater abstraction for the IWSS has been its Operating Strategy, compliance with which is required as a condition on its various IWSS water licences. The Water Corporation's Operating Strategy does not contain any clear requirement to meet the new rule. ${ }^{428}$ We understand that the rules governing groundwater allocations for the IWSS are an ongoing point of discussion between the Water Corporation and the Department of Water.

\footnotetext{
${ }^{426}$ Department of Water, 'Gnangara Groundwater Areas Water Management Plan: Draft for Public Comment' (2008).

427 Department of Water, 'Gnangara Groundwater Allocation Plan', above n 39, 56.

${ }^{428}$ It does not refer to a 5-year, $110 \mathrm{GL} / \mathrm{yr}$ abstraction average. The closest it comes to this is a reference to the Corporation preparing, in a drought situation in which more than $120 \mathrm{GL} / \mathrm{yr}$ is required, 'a proposed program that the Corporation will adopt to ensure that abstraction is returned to a $120 \mathrm{GL}$ per year average': Water Corporation, Integrated Water Supply Scheme: Water Resource Management Operation Strategy 2012-2017 (2012).
} 
This case study exposes some of the challenges and pitfalls in using groundwater as a 'drought reserve', particularly in a drying climate. If groundwater storage is to be temporarily run down due to drought, there need to be well designed and enforceable rules to return water to the aquifer in wetter years. While acknowledging the extraordinary water supply challenges of the period in question, it has to be said that neither the VGAR nor the current abstraction rule meet those criteria. Even if the Operating Strategy is amended to provide that the Water Corporation's total abstraction for the IWSS must conform to a 110GL average over 5 years, there is real doubt as to whether such a requirement would be enforceable under the current RIWI Act, which has no provision for binding annual variation of allocations. ${ }^{429}$

How could the use of groundwater as a drought reserve be better regulated in the future? We suggest three possible approaches that could be built on to the National Water Initiative model of allocation. The key to each of those options are firm legal safeguards to ensure that a realistic allocation limit is set for a drying climate, and that groundwater extraction is below that limit in relatively wet years to provide room to increase extraction in drought.

First, statutory water plans could provide for 'carryover' or 'borrowing' arrangements in appropriate cases. 'Carryover' would allow entitlement holders to carry over unused allocations from previous years. 'Borrowing' would allow entitlement holders to increase their allocation in one year but pay it back in future years. These rules would allow water users to make their own assessment of when groundwater needs to be saved, borrowed and paid back, subject to limitations in the plan (e.g. as to the volume that may be carried over in any year or the number of years of carryover). The facility of 'carryover' and 'borrowing' has been used in other Australian jurisdictions, including for groundwater systems. ${ }^{430}$

A second option, which is a variation of the approach described in the preceding paragraph, would be to require all entitlement holders to 'bank' a proportion (e.g. 10 per cent) of their periodic allocation, so as to build an individual reserve that is accessible to them only in a severe drought as declared by the Minister. This is a publicly mandated saving of water for severe drought, comparable to compulsory superannuation.

A third option would be for the new water resource legislation to provide the capacity to designate formally a volume of water in suitable deeper aquifers as a 'drought reserve'. This would reduce the available consumptive pool for ordinary years, but would ensure that more water could be available in drought years. The legislation could provide the Department with the capacity to auction short term licences to access the reserve in severe droughts.

A fourth option would be to establish an independent statutory authority that could hold share entitlements as a drought reserve. In a severe drought, it would allocate those entitlements preferably through market-based mechanisms such as auctions to ensure that water is directed to its most productive use and to avoid undermining the trading market. In non-drought years, the

\footnotetext{
${ }^{429}$ The Water Corporation currently has a large number of groundwater licences, each of which specifies an 'annual water entitlement' in kilolitres per year and requires that the Operating Strategy be complied with. Notwithstanding the latter requirement, it is difficult to see how the Water Corporation could be prosecuted for taking water other than 'in accordance with' the licence where it is within the entitlement specified on the licence.

${ }^{430} \mathrm{GHD}$ et al, above n 14, 59.
} 
authority could purchase entitlements, using the revenue it had obtained from past auctions. This approach is similar to establishing an independent 'environmental water holder', as has been done in some States of Australia. ${ }^{431}$ Indeed, the State Government may wish to consider one statutory body with the function of holding environmental and drought reserve entitlements.

\section{Law reform recommendation: Sustainable use of groundwater as a 'drought reserve'}

The new legislation should provide the basis for sustainable use of groundwater resources as a 'drought reserve', where appropriate. Regulatory options include:

- The use of 'carryover' or 'borrowing' rules in statutory water allocation plans, leaving it to the entitlement holder to elect when to 'bank' an allocation for later use

- Compulsory 'banking' of a proportion of each entitlement holder's periodic allocation so as to build an individual reserve that is accessible to the entitlement holder in a severe drought as declared by the Minister

- Formal designation of a volume of water in suitable deeper aquifers as a 'drought reserve', accessible through short term licences that are auctioned in severe droughts

- Establishing an independent statutory authority to hold share entitlements as a drought reserve, to be auctioned in extreme droughts.

While there is no space in the main body of this report to deal with this beyond the 'drought reserve' issue, the VGAR case study raises interesting issues as to the relationship between water allocation planning and water supply planning. We make some observations on this issue at Appendix K.

${ }^{431}$ For a survey of environmental water holders in Australia see Erin O'Donnell, 'Australia's Environmental Water Holders: Who is Managing Our Environmental Water' (2013) 28(3) Australian Environment Review 508. 


\section{Conclusion: groundwater regulation in a drying climate}

For groundwater, as with many other natural resources, allocation limits are central to sustainable management. In the absence of limits in some form, we risk suffering Hardin's 'Tragedy of the Commons', in which increased groundwater extraction - apparently rational from the perspective of each individual - leads to over-exploitation of the resource. ${ }^{432}$

Jurisdictions with a 'regulated access' model, under which the state can set limits on extraction by allocating rights to use groundwater, have a head start in avoiding the Tragedy of the Commons. Even so, there are a host of issues to address. How should limits be set? How should rights be allocated? Can rights, once allocated, be changed? As the experience of South West of Western Australia shows, these questions become more difficult in a drying climate, and flaws in the regulatory framework can be exposed. That experience is also suggesting some important general principles in response.

One obvious principle is that in setting limits, governments should not assume past rainfall is a good guide to the future. ${ }^{433}$ The experience of South West Australia is that drying conditions can lead to over-allocation if those conditions have not been fully anticipated in allocation planning. Learning from this experience, Western Australia is moving to a system that combines climate models with groundwater models to predict future groundwater levels under different extraction regimes. Water laws can help entrench this approach by requiring climate change risks to be addressed in allocation planning. Could those laws go further and mandate the consideration and reporting of the assumptions and outcomes of modelling of the effect of management arrangements on groundwater under climate change scenarios? ${ }^{434}$

A second principle is that the entitlements system must be flexible enough to allow collective extraction to be adjusted under changing conditions. Climate science and hydrogeology do not provide a crystal ball - indeed, there is a 'cascade of uncertainty' from global climate models to regional climate predictions to recharge of local aquifers. ${ }^{435}$ The ability to adjust authorised extraction is, therefore, very important. The central reform of Australia's National Water initiative to establish perpetual entitlements expressed a share of a variable consumptive pool - provides the potential, if properly implemented, to achieve this flexibility. Good design of the entitlements system and of the rules for varying the consumptive pool are essential, if we are to get the balance right between flexibility to manage total extraction and reliability of individual entitlements. Where

\footnotetext{
${ }^{432}$ Garrett Hardin, 'The Tragedy of the Commons' (1968) 162(3859) Science 1243, 1244; see also Elinor Ostrom, Governing the Commons: The Evolution of Institutions for Collective Action (Cambridge University Press, 1990); Syme, Nancarrow and McCreddin, above n 20, 61.

${ }^{433}$ See generally P C D Milly et al, 'Stationarity Is Dead: Whither Water Management?' (2007) 319(5863) Science 573; Craig, above $\mathrm{n} 242$.

${ }^{434}$ Such a duty would need to be specifically provided for: see Arnold v Minister Administering the Water Management Act [2013] NSWLEC 73.

${ }^{435}$ Bates et al, above $\mathrm{n} 231,11$.
} 
the transition to this system involves substantial reductions in water use because of climate change, there may be a case for structural adjustment assistance for water users funded by a levy on greenhouse gas emitters.

A third principle is that the rules for varying allocation limits, and by extension the volumes of water that can be taken by entitlement-holders, may need to be very different for different groundwater resources. In superficial aquifers that maintain base flow to important rivers already under pressure from climate change, extraction may need to be substantially reduced in dry years. Conversely, it may be possible to increase extraction in deeper, more confined aquifers in dry years and reduce that extraction in wetter years. In the latter case, the drying climate will have to be taken into account in assessing what is 'dry' and 'wet' in order to avoid sustained levels of high extraction, as has been the case with the use of Perth's groundwater system for public water supply.

This leads to a fourth principle of great significance to areas facing a drying climate: the need to manage groundwater resources in a way that anticipates future extreme drought. The authors of the United States Third Climate Change Assessment have observed that '[a]s the risk of drought increases, groundwater can play a key role in enabling adaptation to climate variability and drought'. ${ }^{436}$ But how can groundwater meet this need and be managed sustainability in a drying climate? We have outlined some regulatory options for establishing a 'drought reserve'. The key to each of those options are firm legal safeguards to ensure that a realistic allocation limit is set for a drying climate, and that groundwater extraction is below that limit in relatively wet years to save water for increased extraction in drought.

Finally, there is a need to ensure that the regulatory framework encourages the productive and efficient use of groundwater. Market-based mechanisms for the initial release of groundwater, and its subsequent trade, are central to achieving these objectives. However, as has often been said, the market is a good servant but a poor master. There should be the capacity for water allocation plans to reserve water for specified uses where it is in the public interest to do so. The most productive use of groundwater will be often, but not always, by the person who will pay the most for it.

In all of the above areas, the regulatory framework for groundwater management is critical. If groundwater is to be managed sustainably, equitably and efficiently in a drying climate, parliaments and governments must ensure that the right regulatory tools are available, and the right principles and planning approaches are in place to guide the use of those tools. While these tools may not satisfy all future demands for water from an increasing population, they will advance the sustainable management of natural groundwater resources as the foundation for adopting new technologies for demand management, water use efficiency and alternative water sources (recycled waste water and stormwater) that can supplement our water supplies in a drying climate. The adoption of these new technologies will, in turn, raise new legal research questions.

${ }^{436}$ A. Georgakakos et al, 'Ch 3: Water Resources' in M Melillo, Terese (T.C.) Richmond and G W Yohe (eds), Climate Change Impacts in the United States: The Third National Climate Assessment (U.S. Global Change Research Program, 2014) 78. 
Comparison of recommendations in this report and positions in the 2013 Position Paper

\section{Domestic Garden Bores}

Consideration should be given to two options:

- to license new and existing domestic

No proposal to expand regulation of domestic garden bores in specified areas, or garden bores.

- to prohibit the construction of new domestic garden bores in specified areas.

\section{Commercial plantations}

Western Australia's new water resource management legislation should recognise commercial plantations as a consumptive use of groundwater resources and have the capacity to licence water use by commercial plantations in specified areas identified by the statutory planning process.
While not entirely clear, it looks likely that the new legislation will have the capacity to licence water use by commercial plantations (p29).

\section{Statutory water allocation plans}

The legislation should:

- $\quad$ provide for statutory water allocation plans that bind decision-makers performing functions under the legislation and other government agencies exercising powers under other legislation

- require, as part of the process for preparing each statutory water allocation plan, the publication of a scoping document that details how sustainable yields will be assessed

- require plans to identify the sustainable yield of each groundwater resource, explain how the sustainable yield was calculated and explain any discrepancy between the sustainable yield and the provisions of the plan

- provide that plans must be approved by the Cabinet (Governor in Council) and then tabled in Parliament and subject to disallowance

- specify the monitoring that is to be carried
The position on these issues is as follows:

- legal effect: plans will 'have the force of law' (p19)

- method for assessing sustainable yield:

- the paper states that '[w]e need to make sure the amount of water we are drawing on is sustainable' (p7), but does not indicate what procedures will be adopted to achieve this

- there may be scope to identify how sustainable yields will be assessed in the Ministerial 'notice of intent' to prepare a plan (p19)

- approval, tabling and disallowance:

- not clear whether Cabinet (Governor in Council) approval required

- plans will be tabled in Parliament (p19)

_ plans 'will be subject to 
out to assess whether the objectives of plans are being achieved, and requirements for the reporting of that information.
Parliamentary scrutiny' (p19), which suggests either House of Parliament could disallow

- monitoring and reporting: plans (rather than the legislation) will 'set out a program for monitoring the operation and effectiveness of the plan' and the 'time or times when the Minister will report on the operation of the plan, the periods to be covered by reports and the matters to be reported on' (p19).

\section{Duty to consider and address climate change in making statutory water allocation plans}

The legislation should require the Minister to consider climate change risks in the preparation of statutory water allocation plans and to address those risks in the plan provisions.
Suggests that plans will 'describe the effects or potential effects of climate variability or change on the water resources and identify the policies and programmes that are included in the plan for managing these effects' (p19).

\section{Reservation of groundwater}

The new water resource management legislation should provide that statutory water allocation plans may reserve water for specified purposes.

Position on reservation not clear. In relation to public water supply, the Position Paper states: 'Public water supply is presently accorded a high priority in water planning. This approach will continue in the setting of statutory allocation limits and statutory water allocation plans strengthened by the capacity to assign purpose, priority and performance to ensure provision for current and future use of public water supply.' (p27)

\section{A more flexible entitlements system}

The legislation should provide greater flexibility to adjust levels of groundwater extraction in response to seasonal circumstances through non-compensable adjustments made by:

- a new system of water entitlements that provide access to a share of a consumptive pool determined periodically, rather than to a fixed annual volume of water
The Position Paper contains the same proposals (pp13-15). 
- pending the introduction of those entitlements, powers to vary more easily the volume of water that may be taken under existing licences.

\section{A regular plan review of entitlements}

The legislation should provide a capacity for longer term adjustments to climate change impacts by providing for:

- regular plan review every ten years

- a fair process by which the minister may amend plan provisions to re-set the regime of rules for determination of the consumptive pool and share entitlements.
The Position Paper indicates that a review period of 'generally no more than 10 years' will be included in the plans, rather than specified in legislation (p18).

\section{Risk assignment and compensation}

No compensation should be payable for adjustments to consumptive pools, or the rules governing the determination of consumptive pools, by regular end of term plan review and amendment. Permanent regulatory adjustments to consumptive pools and entitlements during the term of the plan would be compensable.

\section{Improved water accounting}

The legislation should provide for:

- the implementation of increased metering as proposed by the 2013 Position Paper

- a strengthening of enforcement provisions for non-compliance with licence conditions requiring metering and reporting

- reform of the provisions for the water register to mandate on-line publication of
'New risk assignment provisions will be included in the legislation specifying that the risk of permanent cuts to the entitlement is borne by the water user rather than the government if the cut is due to climate or natural events alone. If the cuts are not due to climate or natural events alone, the risks could be shared between the government and the water users. Where the government bears the risk, for example, through a change in government policy, compensation is payable unless cuts to water entitlements are fair and reasonable. This means that cuts have to be equitable, but not necessarily equal. Compensation is not payable for the recouping of unused licensed entitlements, or for temporary allocation announcements.' (p25)
The position on these issues is as follows:

- metering: metering will be required for share entitlements, and within 5 years (subject to some exceptions) metering will be required for all groundwater licences (p20)

- compliance and enforcement: broad commitment to 'ensure that all appropriate 
licence conditions for metering and of the metering data unless the licensee can show a good reason for non-disclosure

- the capacity to introduce 'net' accounting for groundwater entitlements. offences are included in the legislation and penalties are a sufficient deterrent (p28).

- net accounting: no discussion of this issue.

\section{Initial allocation of groundwater through market-based mechanisms}

The legislation should provide a clear legal basis for the release of unallocated water through a range of mechanisms, including market-based mechanisms such as auctions. Market-based mechanisms should be considered the default approach for heavily allocated groundwater resources.
The legislation will allow for unallocated water to be granted by a variety of mechanisms, including 'FIFS [first in, first served], competitive submission according to certain criteria which may not involve payment for the water, market mechanisms or other suitable means.' (p22).

\section{Use of revenue from groundwater allocation}

The revenue from the release of groundwater through auctions and other market-based mechanisms should be directed to water resource management.
This issue is not addressed in the Position Paper.

\section{Water trading}

The legislation should be designed to facilitate trade in groundwater entitlements, including through implementation of the reforms outlined in the 2013 Position Paper. The legislation should include the capacity to remove the requirement that a purchaser of an entitlement must be an owner or occupier of the land from which the water will be taken.
Position Paper contains proposals (p11) to

- simplify the assessment process for trades and transfers

- include generic, state-wide trading rules in the new legislation

- traded volumes and prices to be made publicly available

There is no proposal to revisit the 'owner or occupier' requirement.

\section{Sustainable use of groundwater as a 'drought reserve'}

The new legislation should provide the basis for sustainable use of groundwater resources as a 'drought reserve', where appropriate. Regulatory options include:

- The use of 'carryover' or 'borrowing' rules in statutory water allocation plans, leaving it to the entitlement holder to elect when to 'bank' an allocation for later use

- Compulsory 'banking' of a proportion
This issue is not addressed in the Position Paper. 
of each entitlement holder's periodic allocation so as to build an individual reserve that is accessible to the entitlement holder in a severe drought as declared by the Minister

- Formal designation of a volume of water in suitable deeper aquifers as a 'drought reserve', accessible through short term licences that are auctioned in severe droughts

- Establishing an independent statutory authority to hold share entitlements as a drought reserve, to be auctioned in extreme droughts. 


\section{Extract from Arrowsmith Groundwater Allocation Plan ${ }^{437}$}

\begin{tabular}{|c|c|c|c|c|c|c|}
\hline \multicolumn{2}{|l|}{ Rescource } & \multirow{2}{*}{$\begin{array}{l}\text { Allocation } \\
\text { limit }{ }^{2} \text { k1/yr }\end{array}$} & \multicolumn{2}{|c|}{ Unlicensed components } & \multirow{2}{*}{$\begin{array}{l}\text { Licensable } \\
\text { component } \\
\text { Ceneral } \\
\text { licensing kL/yr }\end{array}$} & \multirow{2}{*}{$\begin{array}{l}\text { Status of water } \\
\text { availability for } \\
\text { licensing }^{2}\end{array}$} \\
\hline Subarea & Aquifer & & $\begin{array}{r}\text { Public water } \\
\text { supply } \\
\text { reserve kl/yr }\end{array}$ & $\begin{array}{r}\text { Exempt } \\
\text { unlicensed } \\
\mathrm{kl} / \mathrm{yr}\end{array}$ & & \\
\hline Allanooka & Yarragadee & 28800000 & 8000000 & 300000 & 20500000 & water available \\
\hline \multirow[t]{7}{*}{ Darling } & Cattamarra & $(400000)$ & 0 & 0 & $(400000)$ & unknown \\
\hline & Eneabba & $(400000)$ & 0 & 0 & $(400000)$ & unknown \\
\hline & Lesueur & 1400000 & 0 & 0 & 1400000 & water available \\
\hline & $\begin{array}{l}\text { Leederville - } \\
\text { Parmelia }\end{array}$ & $(100000)$ & 0 & 0 & $(100000)$ & unknown \\
\hline & Surficial & 2500000 & 0 & 350000 & 2150000 & water available \\
\hline & Fractured rock & $\begin{array}{r}\text { Not } \\
\text { applicable }\end{array}$ & 0 & 240000 & Not applicable & unknown \\
\hline & Yarragadee & $(200000)$ & 0 & 0 & $(200000)$ & unknown \\
\hline \multirow[t]{3}{*}{ Dongara } & Cattamarra & $(200000)$ & 0 & 0 & $(200000)$ & unknown \\
\hline & Superficial & 8000000 & 0 & 370000 & 7630000 & water available \\
\hline & Yarragadee & 4500000 & 0 & 750000 & 3750000 & water available \\
\hline
\end{tabular}

Allocation limits shown in brackets are an estimate only. Applications to obtain water from these aquifers will require a comprehensive hydrogeological investigation before the water can be allocated. Contact the Mid West Gascoyne regional office in Geraldton for more information.

${ }^{437}$ Department of Water, 'Arrowsmith Groundwater Allocation Plan' (2010) 10, 11. 
South-west groundwater plans

\begin{tabular}{|l|l|}
\hline Non-Statutory Plans & Proclaimed groundwater area \\
\hline Cockburn Groundwater Area Allocation Plan (2007) & Cockburn \\
\hline $\begin{array}{l}\text { Kemerton Groundwater Subareas Water } \\
\text { Management Plan (2007) }\end{array}$ & $\begin{array}{l}\text { Bunbury } \\
\text { South West Coastal }\end{array}$ \\
\hline $\begin{array}{l}\text { Rockingham-Stakehill Groundwater Area Water } \\
\text { Management Plan (2008) }\end{array}$ & $\begin{array}{l}\text { Rockingham } \\
\text { Stakehill }\end{array}$ \\
\hline $\begin{array}{l}\text { Gnangara Groundwater Areas Allocation Plan } \\
\text { (2009) }\end{array}$ & $\begin{array}{l}\text { Gingin (south of Gingin Brook) } \\
\text { Gnangara } \\
\text { Yanchep } \\
\text { Wanneroo } \\
\text { Mirrabooka } \\
\text { Gwelup } \\
\text { Perth } \\
\text { Swan }\end{array}$ \\
\hline $\begin{array}{l}\text { South West Groundwater Areas Allocation Plan } \\
\text { (2009) }\end{array}$ & $\begin{array}{l}\text { Bunbury } \\
\text { Busselton-Capel } \\
\text { Blackwood } \\
\text { South West Coastal }\end{array}$ \\
\hline Upper Collie Water Allocation Plan (2009) & Collie \\
\hline Arrowsmith Groundwater Allocation Plan (2010) & Arrowsmith \\
\hline Jurien Groundwater Allocation Plan (2010) & Jurien \\
\hline Murray
\end{tabular}

\begin{tabular}{|l|l|}
\hline Draft Non-Statutory Plans & Proclaimed groundwater area \\
\hline Gingin Groundwater Allocation Plan (2013) & Gingin \\
\hline
\end{tabular}

\begin{tabular}{|l|}
\hline Proclaimed South West groundwater areas \\
without plans \\
\hline Albany \\
\hline Dwellingup \\
\hline Jandakot \\
\hline Rottnest \\
\hline Serpentine \\
\hline
\end{tabular}


Evaluation Statements for South West Groundwater Plans

\begin{tabular}{|c|c|c|c|c|c|c|}
\hline $\begin{array}{l}\text { Non-Statutory Plans } \\
\text { (publication date) }\end{array}$ & 2008 & 2009 & 2010 & 2011 & 2012 & 2013 \\
\hline $\begin{array}{l}\text { Cockburn } \\
\text { (December 07) }\end{array}$ & N/A & $x$ & $x$ & $\begin{array}{c}\sqrt{ } \\
(07-11)\end{array}$ & $x$ & $x$ \\
\hline $\begin{array}{l}\text { Kemerton } \\
\text { (December 2007) }\end{array}$ & N/A & $x$ & $x$ & $x$ & $x$ & $x$ \\
\hline $\begin{array}{l}\text { Rockingham- } \\
\text { Stakehill (November } \\
\text { 2008) }\end{array}$ & $\mathrm{N} / \mathrm{A}$ & $x$ & $x$ & $\begin{array}{c}\sqrt{ } \\
(08-11)\end{array}$ & $x$ & $x$ \\
\hline $\begin{array}{l}\text { Gnangara } \\
\text { (November 2009) }\end{array}$ & N/A & N/A & $x$ & $x$ & $x$ & $\begin{array}{c}\sqrt{ } \\
(09-11)\end{array}$ \\
\hline $\begin{array}{l}\text { South West } \\
\text { (May 2009) }\end{array}$ & $\mathrm{N} / \mathrm{A}$ & N/A & $x$ & $x$ & $x$ & $\begin{array}{c}\sqrt{ } \\
(09-12)\end{array}$ \\
\hline $\begin{array}{l}\text { Upper Collie } \\
\text { (August 2009) }\end{array}$ & $\mathrm{N} / \mathrm{A}$ & $\mathrm{N} / \mathrm{A}$ & $x$ & $x$ & $x$ & $x$ \\
\hline $\begin{array}{l}\text { Arrowsmith } \\
\text { (August 2010) }\end{array}$ & $\mathrm{N} / \mathrm{A}$ & $\mathrm{N} / \mathrm{A}$ & $\mathrm{N} / \mathrm{A}$ & $x$ & $\begin{array}{c}\sqrt{ } \\
(10-11)\end{array}$ & $x$ \\
\hline $\begin{array}{l}\text { Jurien } \\
\text { (August 2010) }\end{array}$ & $\mathrm{N} / \mathrm{A}$ & $\mathrm{N} / \mathrm{A}$ & $\mathrm{N} / \mathrm{A}$ & $x$ & $\begin{array}{c}\sqrt{ } \\
(10-11)\end{array}$ & $x$ \\
\hline $\begin{array}{l}\text { Murray } \\
\text { (May 2012) }\end{array}$ & $\mathrm{N} / \mathrm{A}$ & $\mathrm{N} / \mathrm{A}$ & $\mathrm{N} / \mathrm{A}$ & $\mathrm{N} / \mathrm{A}$ & $\mathrm{N} / \mathrm{A}$ & $x$ \\
\hline
\end{tabular}


Treatment of climate change in South West groundwater allocation plans ${ }^{438}$

\begin{tabular}{|c|c|c|}
\hline Plan & $\begin{array}{l}\text { Proclaimed } \\
\text { groundwater } \\
\text { area }\end{array}$ & Treatment of climate change \\
\hline $\begin{array}{l}\text { Cockburn } \\
\text { Groundwater Area } \\
\text { Allocation Plan (2007) }\end{array}$ & Cockburn & $\begin{array}{l}\text { Noted that climate change may lead to reductions in } \\
\text { allocation limits in the future. Average rainfall over 'last } \\
28 \text { years' (1968-2006) used in determining allocation } \\
\text { limits (p63). }\end{array}$ \\
\hline $\begin{array}{l}\text { Kemerton } \\
\text { Groundwater } \\
\text { Subareas Water } \\
\text { Management Plan } \\
(2007)\end{array}$ & $\begin{array}{l}\text { Bunbury } \\
\text { South West } \\
\text { Coastal }\end{array}$ & $\begin{array}{l}\text { Climate change noted as an issue that may lead to } \\
\text { reductions in allocation limits in the future. } 1970-1999 \\
\text { rainfall used in determining allocation limits (p21). }\end{array}$ \\
\hline $\begin{array}{l}\text { Rockingham-Stakehill } \\
\text { Groundwater Area } \\
\text { Water Management } \\
\text { Plan (2008) }\end{array}$ & $\begin{array}{l}\text { Rockingham } \\
\text { Stakehill }\end{array}$ & $\begin{array}{l}\text { Climate change noted as an issue that may lead to } \\
\text { reductions in allocation limits in the future. } 1975-2003 \\
\text { rainfall used in determining allocation limits ( } \mathrm{p} 46) \text {. }\end{array}$ \\
\hline $\begin{array}{l}\text { Gnangara } \\
\text { Groundwater Areas } \\
\text { Allocation Plan (2009) }\end{array}$ & $\begin{array}{l}\text { Gnangara } \\
\text { Yanchep } \\
\text { Wanneroo } \\
\text { Mirrabooka } \\
\text { Gwelup } \\
\text { Perth } \\
\text { Swan } \\
\text { Part of Gingin }\end{array}$ & $\begin{array}{l}\text { Climate change noted as an issue that has contributed } \\
\text { to decline in groundwater levels and may affect water } \\
\text { quality (p15). The Plan itself did not indicate what } \\
\text { rainfall assumptions were used in determining } \\
\text { allocation limits. However, a Statement of Response to } \\
\text { public submissions indicates that } 1976-2004 \text { rainfall } \\
\text { was used for the superficial aquifer (Gnangara } \\
\text { Mound). }{ }^{439} \\
\text { The Department also separately published modelling } \\
\text { that included a dryer climate scenario (1996-2004 } \\
\text { rainfall). This scenario showed that 'substantial } \\
\text { additional declines ( } 450 \text { to } 500 \mathrm{GL} \text { ) on top of the base } \\
\text { case declines ( } 400 \mathrm{G} \text { ) equate to } 850 \mathrm{GL} \text { of storage } \\
\text { decrease across Gnangara Groundwater Mound. } \\
\text { The Allocation Plan flagged that the Department would } \\
\text { 'develop a framework for determining ecological water } \\
\text { requirements in a drying climate' (p69). }\end{array}$ \\
\hline
\end{tabular}

\footnotetext{
${ }^{438}$ Michael Bennett acknowledges the assistance of Department of Water analysis in preparing this table.

${ }^{439}$ Department of Water, above n 225, 6; Vogwill et al, above n 226,11.

${ }^{440}$ Vogwill et al, above $\mathrm{n} 226,58$.
} 


\begin{tabular}{|c|c|c|}
\hline $\begin{array}{l}\text { South West } \\
\text { Groundwater Areas } \\
\text { Allocation Plan (2009) }\end{array}$ & $\begin{array}{l}\text { Bunbury } \\
\text { Busselton- } \\
\text { Capel } \\
\text { Blackwood } \\
\text { SW Coastal }\end{array}$ & $\begin{array}{l}\text { Noted CSIRO modelling predicting that between } 1990 \\
\text { and } 2030 \text { the South West may experience a } 5 \text { to } 11 \% \\
\text { decline in average rainfall based on low }\left(0.54^{\circ} \mathrm{C} \text { by }\right. \\
\left.2030) \text { and high ( } 1.24^{\circ} \mathrm{C} \text { by } 2030\right) \text { global warming } \\
\text { scenarios (p13). For future allocation scenarios the } \\
\text { department calculated recharge using a baseline of } \\
\text { 1971-2003 rainfall and reduced recharge by an } \\
\text { additional } 5 \text { per cent (all aquifers) to represent the } \\
\text { decline in rainfall predicted by the CSIRO (pp13-14). }\end{array}$ \\
\hline $\begin{array}{l}\text { Upper Collie Water } \\
\text { Allocation Plan (2009) }\end{array}$ & Collie & $\begin{array}{l}\text { Climate change noted as an issue in the surface water } \\
\text { section of the plan, but not in the groundwater part of } \\
\text { the plan. For groundwater, recharge calculated using } \\
\text { average rainfall from 1979-1999 (p14). }\end{array}$ \\
\hline $\begin{array}{l}\text { Arrowsmith } \\
\text { Groundwater } \\
\text { Allocation Plan (2010) }\end{array}$ & Arrowsmith & $\begin{array}{l}\text { Climate change not mentioned. The plan does not } \\
\text { indicate how mean annual rainfall was calculated (e.g. } \\
\text { whether it was based on the recent historical record). } \\
\text { (p33). }\end{array}$ \\
\hline $\begin{array}{l}\text { Jurien Groundwater } \\
\text { Allocation Plan (2010) }\end{array}$ & Jurien & $\begin{array}{l}\text { Climate change not mentioned. The plan does not } \\
\text { indicate how mean annual rainfall was calculated. } \\
\text { (p33). }\end{array}$ \\
\hline $\begin{array}{l}\text { Murray Groundwater } \\
\text { Allocation Plan (2012) }\end{array}$ & Murray & $\begin{array}{l}\text { The 'observed drying climate trend in the South West of } \\
\text { Western Australia' was noted as one of the factors } \\
\text { triggering a review of the plan and the } 1998 \text { allocation } \\
\text { limits (p1). The methods report states that 1975-2009 } \\
\text { rainfall was used to calculate recharge. The Plan } \\
\text { indicates that the 'future climate scenario adopted for } \\
\text { the South West Coastal groundwater allocation plan (in } \\
\text { preparation)' would be used in annual evaluations } \\
\text { (p27). }\end{array}$ \\
\hline $\begin{array}{l}\text { Draft Gingin } \\
\text { Groundwater } \\
\text { Allocation Plan (2013) }\end{array}$ & Gingin & $\begin{array}{l}\text { Assumes a } 15 \text { per cent reduction in average annual } \\
\text { recharge by } 2020 \text { (p22), but does not indicate which } \\
\text { years were used to calculate average annual recharge. }\end{array}$ \\
\hline
\end{tabular}


Over-allocated groundwater resources in the South West (2014)

\begin{tabular}{|c|c|c|c|c|}
\hline Plan area & Groundwater area & Subarea & Resource & Allocation \\
\hline Cockburn & Cockburn & Cockburn Confined & Perth - Leederville. & $111.11 \%$ \\
\hline Cockburn & Cockburn & Cockburn Confined & Perth - Yarragadee North. & $100.11 \%$ \\
\hline Gingin & Gingin & $\begin{array}{l}\text { Central Coastal Semi- } \\
\text { confined }\end{array}$ & Perth - Leederville. & $161.89 \%$ \\
\hline Gingin & Gingin & Cowalla Confined & $\begin{array}{l}\text { Perth - Leederville - } \\
\text { Parmelia. }\end{array}$ & $109.32 \%$ \\
\hline Gingin & Gingin & Guilderton North & Perth - Superficial Swan & $111.39 \%$ \\
\hline Gingin & Gingin & Red Gully & Perth - Superficial Swan & $133.13 \%$ \\
\hline Gingin & Gingin & SA 3 South & Perth - Leederville. & $116.26 \%$ \\
\hline Gnangara & Gingin & Beermullah Plain South & Perth - Superficial Swan & $104.66 \%$ \\
\hline Gnangara & Gnangara & Gnangara Confined & Perth - Yarragadee North. & $214.56 \%$ \\
\hline Gnangara & Gwelup & Gwelup Confined & Perth - Leederville. & $111.45 \%$ \\
\hline Gnangara & Mirrabooka & Mirrabooka Confined & Perth - Yarragadee North. & $126.58 \%$ \\
\hline Gnangara & Mirrabooka & State Forest & Perth - Superficial Swan & $103.25 \%$ \\
\hline Gnangara & Perth & City of Nedlands & Perth - Superficial Swan & $102.36 \%$ \\
\hline Gnangara & Perth & City of Perth & Perth - Superficial Swan & $143.47 \%$ \\
\hline Gnangara & Perth & City of Subiaco & Perth - Superficial Swan & $112.92 \%$ \\
\hline Gnangara & Perth & Town of Vincent & Perth - Superficial Swan & $153.82 \%$ \\
\hline Gnangara & Swan & Central Swan & Perth - Superficial Swan & $143.25 \%$ \\
\hline Gnangara & Swan & East Swan & Perth - Superficial Swan & $141.99 \%$ \\
\hline Gnangara & Swan & Neaves & Perth - Superficial Swan & $182.74 \%$ \\
\hline Gnangara & Swan & North Swan & Perth - Superficial Swan & $149.62 \%$ \\
\hline Gnangara & Swan & Radar & Perth - Superficial Swan & $103.14 \%$ \\
\hline Gnangara & Swan & South Swan & Perth - Mirrabooka & $100.08 \%$ \\
\hline Gnangara & Swan & South Swan & Perth - Superficial Swan & $103.92 \%$ \\
\hline Gnangara & Swan & Swan Confined & Perth - Leederville. & $110.06 \%$ \\
\hline Gnangara & Wanneroo & Adams & Perth - Superficial Swan & $120.97 \%$ \\
\hline Gnangara & Wanneroo & Carabooda & Perth - Superficial Swan & $137.58 \%$ \\
\hline Gnangara & Wanneroo & Lake Gnangara & Perth - Superficial Swan & $106.06 \%$ \\
\hline Gnangara & Wanneroo & Mariginiup & Perth - Superficial Swan & $116.14 \%$ \\
\hline Gnangara & Wanneroo & Neerabup & Perth - Superficial Swan & $104.50 \%$ \\
\hline Gnangara & Wanneroo & Nowergup & Perth - Superficial Swan & $152.12 \%$ \\
\hline Gnangara & Wanneroo & Pinjar & Perth - Superficial Swan & $136.97 \%$ \\
\hline Gnangara & Wanneroo & Wanneroo Confined & Perth - Leederville. & $114.68 \%$ \\
\hline Gnangara & Wanneroo & Wanneroo Confined & Perth - Yarragadee North. & $122.00 \%$ \\
\hline Murray & Murray & Pinjarra & $\begin{array}{l}\text { Perth - Cattamarra Coal } \\
\text { Measures. }\end{array}$ & $253.40 \%$ \\
\hline $\begin{array}{l}\text { Rockingham- } \\
\text { Stakehill }\end{array}$ & Stakehill & Stakehill Confined & Perth - Leederville. & $121.04 \%$ \\
\hline SWGA & Blackwood & Cape to Cape South & Perth - Blackwood Surficial & $880.00 \%$ \\
\hline SWGA & Bunbury & Bunbury East & Perth - Leederville. & $116.20 \%$ \\
\hline SWGA & Bunbury & Dardanup & Perth - Superficial Swan & $383.29 \%$ \\
\hline SWGA & Bunbury & $\begin{array}{l}\text { Kemerton Industrial } \\
\text { Park South }\end{array}$ & Perth - Superficial Swan & $472.38 \%$ \\
\hline SWGA & Bunbury & Kemerton South & Perth - Leederville. & $100.15 \%$ \\
\hline SWGA & Busselton-Capel & Cape to Cape North & Perth - Blackwood Surficial & $244.73 \%$ \\
\hline
\end{tabular}




\begin{tabular}{|l|l|l|l|r|} 
& Busselton-Capel & Cowaramup & Perth - Blackwood Surficial & \\
\hline SWGA & & & & $108.87 \%$ \\
\hline SWGA & Busselton-Capel & Donnybrook & Perth - Leederville. & $108.88 \%$ \\
\hline Upper Collie & Busselton-Capel & Dunsborough-Vasse & Perth - Leederville. & $102.30 \%$ \\
\hline Upper Collie & Collie & Cardiff & Collie - Lower Collie Group. & \\
\hline & & & & $296.39 \%$ \\
\hline Upper Collie & Collie & Cardiff & Collie - Muja. & $145.53 \%$ \\
\hline
\end{tabular}


Areas Suitable/Unsuitable for Additional Garden Bores in the Perth Region $2011^{441}$

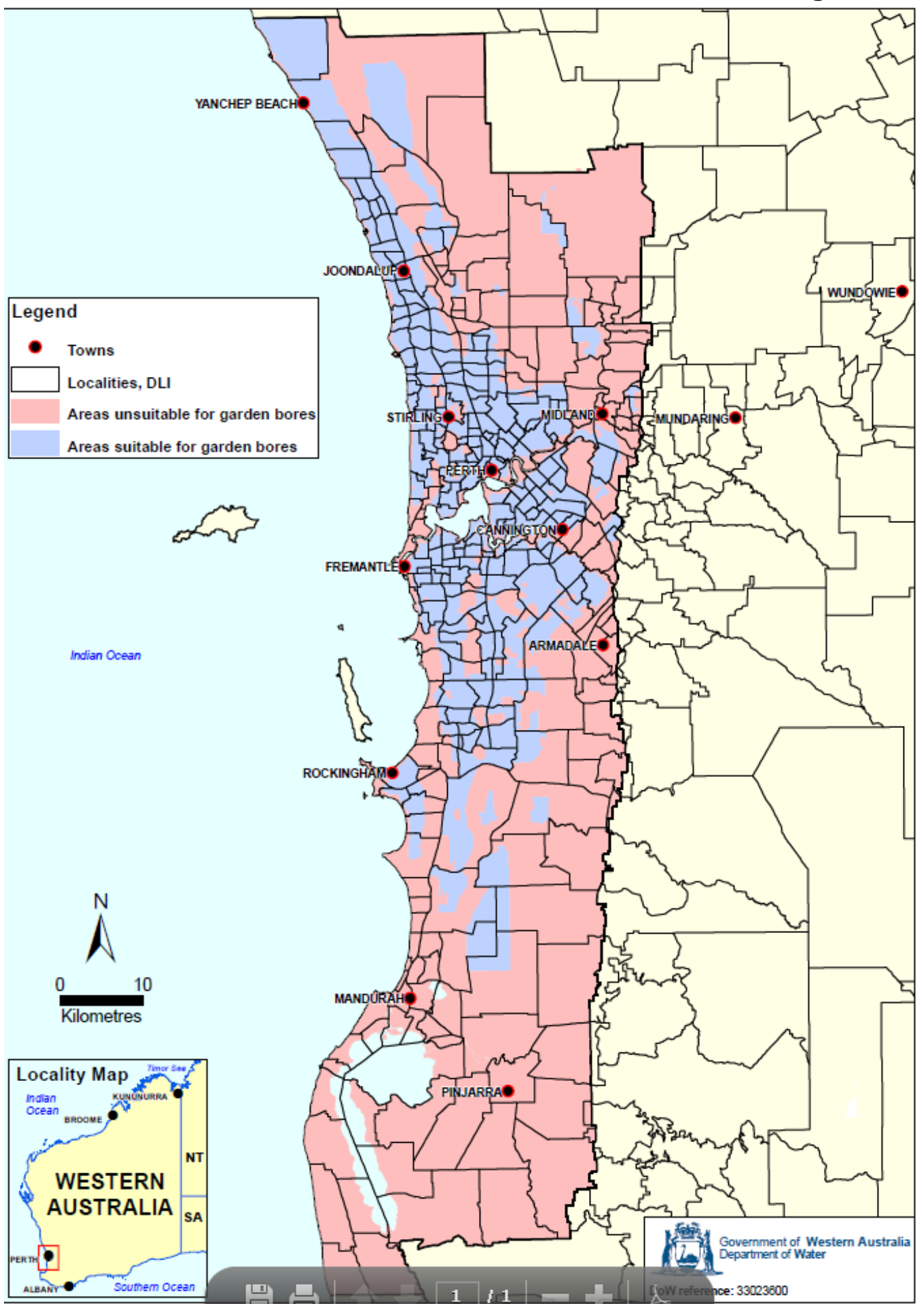

${ }^{441}$ Department of Water, Areas Suitable/Unsuitable for Additional Garden Bores in the Perth Region 2011 (2011) <http://www.water.wa.gov.au/PublicationStore/first/98714.pdf>. A more detailed, interactive map is available at Department of Water, Perth Groundwater Atlas (22 May 2014), http://www.water.wa.gov.au/idelve/gwa/. 
Appendix $\mathrm{H}$

Transfer of water entitlements in South West Western Australia, 2007-08 to 2012-13 ${ }^{442}$

\begin{tabular}{|c|c|c|c|c|c|c|c|c|c|c|c|c|}
\hline \multirow[b]{2}{*}{$\begin{array}{l}\text { Water } \\
\text { management } \\
\text { area }\end{array}$} & \multicolumn{2}{|c|}{ 2007-08 } & \multicolumn{2}{|c|}{ 2008-09 } & \multicolumn{2}{|c|}{$2009-10$} & \multicolumn{2}{|c|}{$2010-11$} & \multicolumn{2}{|c|}{ 2011-12 } & \multicolumn{2}{|c|}{ 2012-13 } \\
\hline & No. & $\begin{array}{l}\text { Vol. } \\
\text { (ML) }\end{array}$ & No. & $\begin{array}{l}\text { Vol. } \\
\text { (ML) }\end{array}$ & No. & $\begin{array}{l}\text { Vol. } \\
(\mathrm{ML})\end{array}$ & No. & $\begin{array}{l}\text { Vol. } \\
(\mathrm{ML})\end{array}$ & No. & $\begin{array}{l}\text { Vol. } \\
\text { (ML) }\end{array}$ & No & $\begin{array}{l}\text { Vol. } \\
\text { (ML) }\end{array}$ \\
\hline Albany & 0 & 0 & 0 & 0 & 1 & 33 & 0 & 0 & 0 & 0 & 1 & 26 \\
\hline Arrowsmith & 0 & 0 & 0 & 0 & 2 & 13 & 1 & 1625 & 0 & 0 & 1 & 7 \\
\hline Blackwood & - & - & - & - & - & - & - & - & - & - & 1 & 88 \\
\hline Bunbury & 0 & 0 & 2 & 90 & 3 & 356 & 1 & 10 & 4 & 67 & 10 & 900 \\
\hline $\begin{array}{l}\text { Busselton- } \\
\text { Capel }\end{array}$ & 2 & 189 & 0 & 0 & 11 & 416 & 4 & 59 & 4 & 187 & 16 & 812 \\
\hline Cockburn & 0 & 0 & 1 & 4 & 0 & 0 & 3 & 97 & 1 & 5 & 0 & 0 \\
\hline Collie & - & - & - & - & - & - & - & - & - & - & 1 & 37000 \\
\hline Gingin & 0 & 0 & 7 & 812 & 12 & 1108 & 14 & 13016 & 10 & 4478 & 9 & 836 \\
\hline Jandakot & 0 & 0 & 1 & 10 & 0 & 0 & 2 & 108 & 0 & 0 & 2 & 29 \\
\hline Jurien & 0 & 0 & 0 & 0 & 1 & 2200 & 0 & 0 & 0 & 0 & 2 & 2677 \\
\hline Karri & 0 & 0 & 0 & 0 & 0 & 0 & 1 & 800 & 0 & 0 & 0 & 0 \\
\hline Mirrabooka & 0 & 0 & 1 & 13 & 2 & 40 & 1 & 68 & 0 & 0 & 1 & 11 \\
\hline Murray & 0 & 0 & 0 & 0 & 1 & 419 & 1 & 42 & 0 & 0 & 0 & 0 \\
\hline Perth & 2 & 35 & 8 & 188 & 0 & 0 & 4 & 47 & 3 & 19 & 15 & 401 \\
\hline Serpentine & 0 & 0 & 3 & 119 & 4 & 43 & 1 & 15 & 6 & 254 & 4 & 142 \\
\hline $\begin{array}{l}\text { South West } \\
\text { Coastal }\end{array}$ & 0 & 0 & 0 & 0 & 3 & 4626 & 1 & 200 & 2 & 681 & 5 & 769 \\
\hline Stakehill & 0 & 0 & 1 & 21 & 0 & 0 & 5 & 140 & 1 & 49 & 3 & 25 \\
\hline Swan & 5 & 133 & 18 & 464 & 13 & 433 & 15 & 206 & 8 & 295 & 12 & 277 \\
\hline
\end{tabular}

${ }^{442}$ Figures drawn from National Water Commission, 'Australian Water Markets Report 2012-13' (2013) 218-219. 


\begin{tabular}{|c|c|c|c|c|c|c|c|c|c|c|c|c|}
\hline \multirow[b]{2}{*}{$\begin{array}{l}\text { Water } \\
\text { management } \\
\text { area }\end{array}$} & \multicolumn{2}{|c|}{ 2007-08 } & \multicolumn{2}{|c|}{ 2008-09 } & \multicolumn{2}{|c|}{ 2009-10 } & \multicolumn{2}{|c|}{$2010-11$} & \multicolumn{2}{|c|}{ 2011-12 } & \multicolumn{2}{|c|}{ 2012-13 } \\
\hline & No. & $\begin{array}{l}\text { Vol. } \\
\text { (ML) }\end{array}$ & No. & $\begin{array}{l}\text { Vol. } \\
\text { (ML) }\end{array}$ & No. & $\begin{array}{l}\text { Vol. } \\
\text { (ML) }\end{array}$ & No. & $\begin{array}{l}\text { Vol. } \\
\text { (ML) }\end{array}$ & No. & $\begin{array}{l}\text { Vol. } \\
\text { (ML) }\end{array}$ & No & $\begin{array}{l}\text { Vol. } \\
\text { (ML) }\end{array}$ \\
\hline Wanneroo & 5 & 129 & 20 & 394 & 19 & 531 & 10 & 188 & 19 & 412 & 18 & 156 \\
\hline Yanchep & 0 & 0 & 0 & 0 & 0 & 0 & 1 & 11 & 2 & 8 & 3 & 120 \\
\hline Total & 14 & 486 & 62 & 2115 & 73 & 10218 & 65 & 16632 & 60 & 6455 & 103 & 44276 \\
\hline
\end{tabular}


Appendix I

Groundwater leases in South West Western Australia, 2007-08 to 2012-13

\begin{tabular}{|c|c|c|c|c|c|c|c|c|c|c|c|c|}
\hline \multirow[b]{2}{*}{$\begin{array}{l}\text { Water } \\
\text { management } \\
\text { area }\end{array}$} & \multicolumn{2}{|c|}{ 2007-08 } & \multicolumn{2}{|c|}{ 2008-09 } & \multicolumn{2}{|c|}{ 2009-10 } & \multicolumn{2}{|c|}{ 2010-11 } & \multicolumn{2}{|c|}{ 2011-12 } & \multicolumn{2}{|c|}{ 2012-13 } \\
\hline & No. & $\begin{array}{l}\text { Vol. } \\
\text { (ML) }\end{array}$ & No. & $\begin{array}{l}\text { Vol. } \\
\text { (ML) }\end{array}$ & No. & $\begin{array}{l}\text { Vol. } \\
\text { (ML) }\end{array}$ & No. & $\begin{array}{l}\text { Vol. } \\
\text { (ML) }\end{array}$ & No. & $\begin{array}{l}\text { Vol. } \\
\text { (ML) }\end{array}$ & No & $\begin{array}{l}\text { Vol. } \\
\text { (ML) }\end{array}$ \\
\hline Arrowsmith & 0 & 0 & 0 & 0 & 0 & 0 & 0 & 0 & 1 & 1280 & 0 & 0 \\
\hline Blackwood & - & - & - & - & - & - & - & - & - & - & 1 & 0 \\
\hline Bunbury & 0 & 0 & 0 & 0 & 1 & 12 & 2 & 40 & 2 & 90 & 3 & 54 \\
\hline $\begin{array}{l}\text { Busselton- } \\
\text { Capel }\end{array}$ & 0 & 0 & 0 & 0 & 0 & 0 & 2 & 820 & 0 & 0 & 4 & 188 \\
\hline Gingin & 0 & 0 & 0 & 0 & 1 & 2 & 1 & 1132 & 2 & 752 & 5 & 3530 \\
\hline Jurien & 0 & 0 & 1 & 6 & 0 & 0 & 0 & 0 & 0 & 0 & 1 & 75 \\
\hline Perth & 0 & 0 & 0 & 0 & 0 & 0 & 0 & 0 & 2 & 375 & 1 & 20 \\
\hline Serpentine & 1 & 33 & 0 & 0 & 0 & 0 & 0 & 0 & 0 & 0 & 0 & 0 \\
\hline $\begin{array}{l}\text { South West } \\
\text { Coastal }\end{array}$ & - & - & - & - & 1 & 40 & 3 & 2459 & 1 & 50 & 4 & 230 \\
\hline Stakehill & - & - & - & - & - & - & - & - & - & - & 3 & 144 \\
\hline Swan & 0 & 0 & 0 & 0 & 0 & 0 & 0 & 0 & 1 & 454 & 1 & 15 \\
\hline Wanneroo & 0 & 0 & 10 & 286 & 4 & 128 & 1 & 100 & 17 & 1165 & 22 & 1483 \\
\hline Total & 1 & 33 & 11 & 292 & 7 & 182 & 9 & 4551 & 27 & 4166 & 44 & 5739 \\
\hline
\end{tabular}

443 Ibid 221. 


\section{Additional observations on third party appeals}

The licence application process requires the Minister (or delegate) to consider the needs of current and future water users, but those raising concerns on these needs have very few rights. In particular, they have no right to receive reasons for decision that explain how their objection was dealt with and, in contrast with the licence applicant, no right to appeal from the license decision. ${ }^{444}$

There is a strong case for two basic reforms to the RIWI Act:

- introduce a requirement that the Minister (or delegate) must publish reasons for his or her decision on a licence application, so that objectors to a licence know whether their concerns have been properly considered. ${ }^{445}$

- remove the institutional bias in favour of licence applicants by either

o introducing third party appeals; or

o removing applicant appeals.

The introduction of third party appeals would bring Western Australia into line with most other states (see below).

\section{Availability of third party appeals against decisions to grant water licences in Australia}

\begin{tabular}{|ll|}
\hline Jurisdiction & Can third parties appeal? \\
\hline NST & No. ${ }^{446}$ \\
\hline Northern Territory & Yes - person who has objected to the grant may appeal. ${ }^{447}$ \\
\hline Queensland & Yes - person who has made a submission on the application may appeal. ${ }^{449}$ \\
\hline
\end{tabular}

\footnotetext{
${ }^{444}$ Rights in Water and Irrigation Act 1914 (WA) s 26GG.

${ }^{445}$ Compare, for example, s $71 \mathrm{C}(3)$ of the Water Act (NT), which provides, in relation to water extraction licence decisions, that a copy of the full decision must be available to the public. It also provides that the decision must include the reasons for the decision, the way in which comments on the application were dealt with, and how factors specified in the legislation were taken into account.

${ }^{446}$ Water Resources Act 1997 (ACT) s 94, sch 1.

${ }^{447}$ Water Management Act 2000 (NSW) s 368(1)(b). Note, however, that the right to object to a water access licence is restricted: a person cannot object where a statutory 'water sharing plan' is in place: Water Management Act 2000 (NSW) s 62(1)(n).

${ }^{448}$ Water Act (NT) s 30.

449 The provisions are somewhat convoluted. An 'interested person' may apply for internal review of decision: Water Act 2000 (QId) s 861. An 'interested person' is '[a] person who has been given an information notice or a compliance notice by the chief executive, or an authorised officer appointed by the chief executive': $s$ 851. The chief executive officer is required to give an information notice to 'any person who gave a properly made submission about the application': s 211(3). Note that a 'properly made submission' must, among other things, be 'made by a person invited to make the submission': sch 4 (emphasis added). Presumably a public notice calling for submissions is considered an 'invitation' for the purposes of this definition: see s 208 .
} 


\begin{tabular}{|ll|}
\hline South Australia & $\begin{array}{l}\text { No - capacity to provide for third party appeals through regulations, but no such } \\
\text { regulations have been made. }{ }^{450}\end{array}$ \\
\hline Tasmania & Yes - person who has made representation concerning application may appeal. ${ }^{451}$ \\
\hline Victoria & Yes - a person whose interests are affected by the grant may appeal. ${ }^{452}$ \\
\hline WA & No. $^{453}$ \\
\hline
\end{tabular}

The removal of applicant appeals, so that the applicant and third parties would only have access to judicial review of the legality (as opposed to the merits) of the licensing decision is not an approach used in other Australian water legislation, but is used in some other contexts - for example a developer that is refused permission to carry out a 'controlled action' assessed under the Environment Protection and Biodiversity Conservation Act 1999 (Cth) has no access to a merits appeal.

\footnotetext{
${ }^{450}$ Natural Resource Management Act 2005 (SA) s 202(1)(b).

${ }^{451}$ Water Management Act 1999 (Tas) s 270(b).

452 Water Act 1989 (Vic) s 64(1)(b); Niebieski Zamek Pty Ltd v Southern Rural Water [2003] VCAT 223 (25 February 2003) at para 68. Note that s 64(1)(b) relates to water licences; third party appeals are not available concerning the grant of water shares: Water Act 1989 (Vic) s 33AX.

${ }^{453}$ Rights in Water and Irrigation Act 1914 (WA) s 26GG(2).
} 


\section{Appendix K}

\section{Additional observations on water supply and demand management planning}

The effectiveness of groundwater management in responding to changing climatic conditions will inevitably be dependent, at least in part, on planning processes outside the formal groundwater allocation planning framework. One important area is public water supply and demand management planning. Clearly, groundwater allocation planning and water supply planning affect each other. The constraints imposed by groundwater allocation limits can accelerate planning for other water sources (e.g. desalination); conversely, if alternative water sources are not planned for and available when rainfall declines then there is likely to be strong community and political pressure for generous groundwater allocations to avoid severe water restrictions.

A detailed examination of public water supply planning is beyond the scope of this Report, but we will note some issues that would benefit from more detailed legal analysis. First, there are institutional questions: who should be responsible for carrying out water supply and demand management planning? It could be argued that the approach in the South West over recent decades - of giving a monopoly provider the task of delivering, and to a large extent planning, public water supply promotes good contingency planning and a rapid response to a drying climate. ${ }^{454}$ On the other hand, the Economic Regulation Authority has argued that a lower cost solution would be an 'Independent Procurement Entity' responsible for procuring water sources and demand management options in line with water security requirements specified by government. ${ }^{455}$

Secondly, there is the question of whether public water supply and demand management planning should be given a legislative basis. As we have seen, there is a legislative basis for water allocation plans, which the government intends to refresh through new legislation to replace the RIWI Act. The new legislation will no doubt include guiding principles, consultation requirements and the like. Should water supply and demand management planning have a similar legislative basis - including a duty to consider the impacts of climate change? California is one jurisdiction that has adopted this approach (see case study below). In Western Australia, one option would be the use of a legislative instrument - a Code of Practice under the Water Services Act 2012 (WA) to address these matters. ${ }^{456}$ Given the significance of climate change for water supply and demand management planning, particularly in the South West of Western Australia, we would recommend that the risks of climate change, and associated responses, should be a mandatory consideration in water supply and demand management planning.

\footnotetext{
${ }^{454}$ M. G. Porter, 'A Tale of Two Cities: Desalination and Drought in Perth and Melbourne' (Alfred Deakin Research Institute, Deakin University, 2013) 21, citing former Water Corporation CEO Dr Jim Gill ('...when the going gets tough, accountability is a million per cent clear - 'one bum to kick' - only one corporation to plan for the very worst contingency.') ${ }^{455}$ Economic Regulation Authority, above n 265 v-vi.

${ }^{456}$ Under ss 26 and 12(q)-(r) of the Water Services Act 2012 (WA) the responsible Minister may make a code of practice dealing with, among other things, 'planning for the development of future water sources' and 'developing and implementing programmes for the conservation and efficient use of water'. Licensees (such as the Water Corporation) must comply with a code of practice as if it were a condition of their licence: Water Services Act 2012 (WA), s 26(3). As to the status of a code of practice as a legislative instrument, see Water Services Act 2012 (WA), s 26(5).
} 


\section{Case Study: Legal requirements for urban water planning in California}

Under California's Urban Water Management Planning (UWMP) $A c t^{457}$ urban water suppliers must prepare an Urban Water Management Plan every 5 years. These plans must assess the reliability of water sources over a 20 -year planning horizon.

Plans must, among other things:

- describe the reliability of the water supply and vulnerability to seasonal or climatic shortage to the extent practicable

- provide data for an average water year, a single dry water year and multiple dry water years

- for any water source that may not be available at a consistent level of use, given specific legal, environmental, water quality, or climatic factors, describe plans to supplement or replace that source with alternative sources or water demand management measures, to the extent practicable. ${ }^{458}$

Before adopting a plan, the urban water supplier must make the plan available for inspection and hold a public hearing on the plan. ${ }^{459}$ The Department of Water Resources reviews plans to make sure they have complied with the requirements in the UWMP Act. ${ }^{460}$

There are water supply and demand management models in Australia that are supported by a legislative base. For example, under the Water Act 1989 (Vic), there is provision for the making of sustainable water strategies which are to provide for the strategic planning of a region's water supply. The legislated requirements are that the strategies identify threats to the supply and quality of environmental and consumptive uses in the region, and set priorities for managing demand for water and investing in infrastructure for the supply of recycled water. There is a public consultation process in the making of the strategies, including the appointment of a panel if desired, and once this is complete the Minister can endorse, amend or reject a strategy. ${ }^{461}$ Four sustainable water strategies have been made under these provisions. ${ }^{462}$ Queensland's Water Supply (Safety and Reliability) Act 2008 also required, for a period, that water service providers prepare 'drought management plans' - however this requirement was removed from the Act by recent amendments on the ground that 'these plans are costly to develop and do not always

\footnotetext{
${ }^{457}$ Division 6 Part 2.6 of the Water Code $\$ 10610$ - 10656.

458 Ibid, §10631.

459 lbid $\$ 10642$.

${ }^{460}$ Department of Water Resources, Urban Water Management (28 August 2012) $<$ http://www.water.ca.gov/urbanwatermanagement/>.

461 Victoria's water legislation is now under review with the aim of integrating two key Acts and streamlining provisions. Significantly, the exposure draft Bill has maintained similar provisions to those in the current Water Act 1989, requiring the preparation of strategic planning reviews that are to identify options to respond to long term risks to water supply and quality, for both environmental and consumptive uses.

${ }^{462}$ Strategies have been made for: The Northern Region, comprising Victoria's share of the Murray River and its tributaries; the Western Region, including agricultural and urban centres in the West; the Gippsland Region including areas south of the Great Dividing Range in Victoria up to the NSW border; and the Central Region, including Melbourne, Geelong and Ballarat and parts of West Gippsland.
} 
contribute to effective ... water security planning. ${ }^{463}$

Finally, there is the issue of what regulatory tools should be available to promote demand management. Examples in Australia include requirements on large users of scheme water to prepare and comply with water efficiency plans, ${ }^{464}$ restrictions on scheme water use (e.g. for watering gardens) ${ }^{465}$ and minimum standards and 'star ratings' to promote more water-efficient products. ${ }^{466} \mathrm{~A}$ useful area of future research would be an international comparative study of regulatory tools of this kind which identify the range of tools, analyse different design features and quantify the water savings they have achieved in practice.

\footnotetext{
${ }^{463}$ The original provisions were in Part 4, Division 6 of the Act. These provisions were repealed by the Water Supply Services Legislation Amendment Act 2014 (Qld) s 69. The quoted words are from Explanatory Notes, Water Supply Services Legislation Amendment Bill 2014, 2.

${ }^{464}$ Water Agencies (Water Use) By-Laws 2010 (WA), Part III.

${ }^{465}$ Water Services Regulations 2013 (WA), Part V.

${ }^{466}$ Water Efficiency and Labelling Standards Act 2005 (Cth) and associated state and territory legislation.
} 


\section{References}

'Premier says desal will 'drought-proof' Perth', Australian Broadcasting Corporation 23 February 2013 <http://www.abc.net.au/news/2013-01-23/second-stage-of-desalination-plant-opened/4480588>

Adler, Jonathon $\mathrm{H}$, 'Water Marketing as an Adaptive Response to the Threat of Climate Change' (2008) 33(3) Hamline Law Review 729

Ali, R. et al, 'Potential climate change impacts on the water balance of regional unconfined aquifer systems in south-western Australia' (2012) 16(12) Hydrology and Earth System Sciences 4581

Ali, Riasat et al, 'Potential climate change impacts on groundwater resources of south-western Australia' (2012) 475 Journal of Hydrology 456

Alley, William M and Stanley A Leake, 'The Journey from Safe Yield to Sustainability' (2004) 42(1) Ground Water 12

Andrich, Mark A. and Jörg Imberger, 'The effect of land clearing on rainfall and fresh water resources in Western Australia: a multi-functional sustainability analysis' (2013) 20(6) International Journal of Sustainable Development \& World Ecology 549

Aqwest, 'Annual Report 2013' (2013)

Australia, Auditor General for Western, 'Renewable Energy: Knowing What We Are Getting' (Report 12, 2007)

Australia, Commonwealth of, 'Australian Water Resource Assessment 2000' (2001)

Bates, Bryson C et al, 'Incorporating climate change in water allocation planning' (2010)

Bates, Gerry, Environmental Law in Australia (LexisNexis Butterworths, 8th ed, 2013)

Benyon, $\mathrm{R}$ et al, 'Tree Water Use in Forestry Compared to Other Dry-Land Agricultural Crops in the Victorian Context: Report prepared for the Department of

Primary Industries Victoria to Promote Scientific Knowledge in this Area ' (2007)

Berti, M L et al, 'Climate Change, Catchment Runoff and Risks to Water Supply in the South-West of Western Australia' (2004)

Bevacqua, John, 'Uncertainties in the Australian Water Availability Risk Assignment Framework: Implications for Environmental Water Reserve Managers' (2011) 30(2) Economic Papers: A journal of applied economics and policy 185

Bredehoeft, J D, 'Safe yield and the water budget myth' (1997) 35(6) Ground Water 929

Busselton Water, 'Annual Report 2012-2013' (Annual Report)

Cai, Wenju and Tim Cowan, 'SAM and regional rainfall in IPCC AR4 models: Can anthropogenic forcing account for southwest Western Australian winter rainfall reduction?' (2006) 33(24) Geophysical Research Letters

Cai, Wenju and Je Shi, 'Multidecadal fluctuations of winter rainfall over southwest Western Australia simulated in the CSIRO Mark 3 coupled model' (2005) 32(12) Geophysical Research Letters

Cai, Wenju, Peter Whetton and David Karoly, 'The Response of the Antarctic Oscillation to Increasing and Stabilized Atmospheric CO2' (2003) 16 Journal of Climate 1525 
Chambers, Jane et al, 'Adapting to climate change: a risk assessment and decision making framework for managing groundwater dependent ecosystems with declining water levels' (National Climate Change Adaptation Research Facility, 2013)

Chung, Vivian, 'Making Waves: An Overhaul of Western Australia's Legislative Framework for the Allocation of Water - Part II' (2007) 26(4) Australian Resources and Energy Law Journal 381

City of Wanneroo, 'Council Agenda: Ordinary Council Meeting, 15 November 2011' (2011)

Commission, National Water, 'Impacts of water trading in the southern Murray-Darling Basin between 200607 and 2010-11' (2012)

Commission, Western Australian Planning, 'Policy No. DC 2.3 - Public Open Space in Residential Areas' (Undated)

Commission, Western Australian Planning and Water and Rivers Commission, 'Gnangara Land Use and Water Management Strategy: Final Report' (2001)

Council of Australian Governments, 'Intergovernmental Agreement on a National Water Initiative' (2004)

Craig, Robin Kundis, "Stationarity is Dead' - Long Live Transformation: Five Principles for Climate Change Adaptation Law' (2010) 34 Harvard Environmental Law Review 9

Crase, Lin, 'An Introduction to Australian Water Policy' in Lin Crase (ed), Water Policy in Australia: The Impact of Change and Uncertainty (Resources for the Future, 2008)

Crommelin, M and R Hunder, 'Water and Mining - Controls in Conflict' (1989) Australian Mining and Petroleum Law Association Yearbook 201

CSIRO, 'Groundwater yields in south-west Western Australia: A report to the Australian Government from the CSIRO South-West Western Australia Sustainable Yields Project' (2009)

CSIRO, 'Water yields and demands in south-west Western Australia: A report to the Australian Government from the CSIRO South-West Western Australia Sustainable Yields Project' (CSIRO, 2009)

CSIRO and Bureau of Meteorology, 'State of the Climate 2014' (Australian Government, 2014)

De Silva, J, 'PRAMS scenario modelling for the Gnangara Sustainability Strategy' (2009)

Dellapenna, Joseph W 'Global climate disruption and water law reform in the United States' in Paul Martin et al (eds), Environmental Governance and Sustainability (IUCN Academy of Environmental Law, 2012)

Department of Fisheries, 'Annual Report 2012-13' (Government of Western Australia, 2013)

Department of Land and Resource Management, 'Draft Alice Springs Water Allocation Plan 2013-2018' (2013)

Department of Natural Resources, Environment, The Arts and Sport,, 'Water Allocation Plan for the Tindall Limestone Aquifer, Katherine 2009 - 2019' (2009)

Department of Planning and Western Australian Planning Commission, 'Directions 2031 and Beyond: Metropolitan Planning Beyond the Horizon' (2010)

Department of Planning and Western Australian Planning Commission, 'Model Subdivision Conditions Schedule' (2012)

Department of Water, 'Arrowsmith Groundwater Allocation Plan' (2010)

Department of Water, 'Briefing Note: Application from Karara Mining Limited for a licence of $5 \mathrm{GL}$ from the Parmelia Aquifer in the Mingenew Subarea' (August 2011) 
Department of Water, 'Cockburn Groundwater Area Water Management Plan' (Government of Western Australia, 2007)

Department of Water, 'Discussion Paper: Review of First-in First-served Policy' (2011)

Department of Water, 'Environmental Management of Groundwater Abstraction from the Gnangara Mound: Triennial compliance report to the Office of the Environmental Protection Authority: Jul 2009 - June 2012' (2013)

Department of Water, 'Gingin Groundwater Allocation Plan: Draft for Public Comment' (Government of Western Australia, 2013)

Department of Water, 'Gnangara Groundwater Areas Allocation Plan' (Department of Water, 2009)

Department of Water, 'Gnangara Groundwater Areas Allocation Plan: Evaluation statement 2009-2011' (2011)

Department of Water, 'Gnangara Groundwater Areas Allocation Plan: Evaluation Statement 2009-2011' (2013)

Department of Water, 'Gnangara Groundwater Areas Allocation Plan: Statement of Response' (2009)

Department of Water, 'Gnangara Groundwater Areas Water Management Plan: Draft for Public Comment' (2008)

Department of Water, 'North West Corridor Water Supply Strategy' (2014)

Department of Water, 'Operational Policy 5.12 - Hydrogeological Reporting Associated with a Groundwater Well Licence' (2009)

Department of Water, 'Operational Policy 5.17 - Metropolitan Domestic Garden Bores' (2011)

Department of Water, 'Plantation Forestry and Water Management Guideline' (2009)

Department of Water, 'Policy on Accessing the Leederville and Yarragadee aquifers in Perth' (2006)

Department of Water, 'Review of the Jurien and Arrowsmith Groundwater Limits: Supporting Information for the Jurien and Arrowsmith Groundwater Allocation Plans' (2009)

Department of Water, 'Securing Western Australia's Water Future: Position paper - Reforming Water Resource Management' (2013)

Department of Water, 'Water Allocation Planning in Western Australia: A Guide to Our Process' (2011)

Department of Water, 'Water planning for the South West Region 2010-2030' (Government of Western Australia, 2010)

Department of Water and Department of Mines and Petroleum, 'Administrative Agreement Between the Department of Mines and Petroleum and the Department of Water for Mineral Exploration and Mining Operations in Water Resources Areas in Western Australia' (2012)

Department of Water (SA), 'Water Licensing: Risk Assignment Policy' (<https://www.waterconnect.sa.gov.au/Content/Publications/DEWNR/Water Licensing Risk Assignment Policy.pdf >

Economic Regulation Authority, 'Final Report Inquiry on Competition in the Water and Wastewater Services Sector' (2008)

Eyre Peninsula Natural Resources Management Board, 'Discussion Paper: Climate Change and Groundwater' (Government of South Australia, 2010) 
Eyre Region Water Resources Planning Commitee, 'Water Allocation Plan for the Musgrave Prescribed Wells Area' (2001)

Foerster, Anita, 'Australian water law: adapting to climate change?' (Paper presented at the IUCN environmental law colloquium 2011)

Foerster, Anita, 'The Murray-Darling Basin Plan 2012: An Environmentally Sustainable Level of Trade-off?' (2013) 16(1) Australasian Journal of Natural Resources Law and Policy 41

Gardner, Alex, 'Mining Access to Water Resources - Traditions and Developing Principles' (Paper presented at the AMPLA, Thirty-Seventh National Conference, Adelaide, South Australia, 2013)

Gardner, Alex, Richard Bartlett and Janice Gray, Water Resources Law (Lexis Nexis Butterworths, 2009)

Garnaut, Ross, The Garnaut Climate Change Review (Cambridge University Press, 2008)

Georgakakos, A. et al, 'Ch 3: Water Resources' in M Melillo, Terese (T.C.) Richmond and G W Yohe (eds), Climate Change Impacts in the United States: The Third National Climate Assessment (U.S. Global Change Research Program, 2014)

GHD et al, 'Guidance for groundwater storage utilisation in water planning' (2012)

Gnangara Coordinating Committee, 'Gnangara Sustainability Strategy: Draft for Public Comment' (Government of Western Australia, 2009)

Goulburn-Murray Water, 'Review of the Katunga Water Supply Protection Area Groundwater Management Plan' (2012)

Goulburn Valley Water, 'Katunga Water Supply System: Drought Response Manual' (2012)

Government of Victoria, 'Groundwater Management Plan for the Katunga Water Supply Protection Area' (2006)

Government of Victoria, 'Loddon Highlands Water Supply Protection Area Groundwater Management Plan' (2012)

Government of Western Australia, 'Clause Notes to the Rights in Water and Irrigation Act 1914 (WA)' (1999)

Government of Western Australia, 'Discussion Paper: Water Resources Management Options' (2009)

Government of Western Australia, 'Government Response to a Blueprint for Water Reform in Western Australia' (2007)

Hardin, Garrett, 'The Tragedy of the Commons' (1968) 162(3859) Science 1243

Hartley, Madelaine, Regulating groundwater use efficiency for sustainable development: the experiences of Colorado, the Namoi Catchment, and the Gnangara Mound (forthcoming) (PhD Thesis, University of Western Australia, 2014)

Horwitz, P. et al, 'Hydrological change escalates risk of ecosystem stress in Australia's threatened biodiversity hotspot' (2008) 91 Journal of the Royal Society of Western Australia

Indian Ocean Climate Initiative, 'Indian Ocean Climate Initiative Stage 3: Summary for Policymakers' (CSIRO and BoM, 2012)

Intergovernmental Panel on Climate Change, 'Climate Change 2014: Impacts, Adaptation, and Vulnerability' (2014)

Ivkovic, KM et al, 'National-scale Vulnerability Assessment of Seawater Intrusion: Summary Report' (2012) 
Langridge, Ruth, 'Confronting Drought: Water Supply Planning and the Establishment of a Strategic

Groundwater Reserve' (2009) 12 University of Denver Water Law Review 295

Lowe, Godfrey, 'The Golden Pipeline' (2004) 2(1) Australian Journal of Multi-disciplinary Engineering 45

Marsden Jacobs Associated, 'Evaluation of mechanisms for releasing unallocated water in Western Australia - Part A: Selection of market instruments' (2010)

McFarlane, Don et al, 'Managing groundwater levels in the face of uncertainty and change: a case study from Gnangara' (2012) 12(3) Water Science \& Technology: Water Supply 321

McKay, Clare and Alex Gardner, 'Water Accounting Information and Confidentiality in Australia' (2013) 41(1) Federal Law Review 127

Metropolitan Region Planning Authority, 'Planning Structure for the North West Corridor' (1977)

Milly, P C D et al, 'Stationarity Is Dead: Whither Water Management?' (2007) 319(5863) Science 573

Morgan, Ruth, 'Dry Horizons: The Responses of Western Australian Water Managers to the Enhanced Greenhouse Effect in the Late 1980s' (2011) 8(3) History Australia 158

Morgan, Ruth A, Running out? An environmental history of climate and water in the southwest of Western Australia, 1829 to 2006 (PhD Thesis, University of Western Australia, 2012)

Murray Darling Basin Authority, 'Guide to the Proposed Basin Plan: Overview' (Murray-Darling Basin Authority, 2010)

Myers, Norman et al, 'Biodiversity hotspots for conservation priorities' (2000) 403 Nature 853

National Water Commission, 'Australian Water Markets Report 2012-13' (2013)

National Water Commission, 'Australian Water Reform 2009: Second Biennial Assessment of Progress in Implementation of the National Water Initiative' (2009)

National Water Commission, 'Ecological water requirements of groundwater systems: a knowledge and policy review' (2011)

National Water Commission, 'National Water Planning Report Card 2011' (2011)

National Water Commission, 'Water Policy and Climate Change in Australia' (National Water Commission, 2012)

Nelson, Rebecca, 'Groundwater: Hidden Promise, Hidden Perils' (Committee for Economic Development of Australia, 2012)

Nelson, Rebecca and Meg Casey, 'Taking Policy from Paper to the Pump: Lessons on Effective and Flexible Groundwater Policy and Management from the Western US and Australia' (2013)

NSW Office of Water, 'Capability and Priority Programs 2013-2015' (2013)

NSW Office of Water, 'NSW Great Artesian Basin Water Auction 2009: Final Report' (2010)

O'Donnell, Erin, 'Australia's Environmental Water Holders: Who is Managing Our Environmental Water' (2013) 28(3) Australian Environment Review 508

Ostrom, Elinor, Governing the Commons: The Evolution of Institutions for Collective Action (Cambridge University Press, 1990)

Pagan, Phil, 'Adaptive Management' in Lin Crase (ed), Water Policy in Australia: The Impact of Change and Uncertainty (Resources for the Future, 2008) 
Panel, Kimberley Expert, 'Options for Bringing Water from Perth to the Kimberley' (2006)

Patashnik, Josh 'All Groundwater is Local: California's New Groundwater Monitoring Law' (2011) 22 Standford Law and Policy Review 317

Petrone, Kevin C. et al, 'Streamflow decline in southwestern Australia, 1950-2008' (2010) 37(11) Geophysical Research Letters

Pitman, A J et al, 'Impact of land cover change on the climate of southwest Western Australia' (2004) 109(D18) Journal of Geophysical Research

Polglase, $\mathrm{P}$ and $\mathrm{R}$ Benyon, 'The impacts of plantations and native forests on water security: Review and scientific assessment of regional issues and research needs' (2009)

Porter, M. G., 'A Tale of Two Cities: Desalination and Drought in Perth and Melbourne' (Alfred Deakin Research Institute, Deakin University, 2013)

Productivity Commission, 'Barriers to Effective Climate Change Adaptation' (2012)

Productivity Commission, 'Market Mechanisms for Recovering Water in the Murray-Darling Basin: Final Report' (2010)

Queensland Government, 'Bowen Groundwater Management Area Water Sharing Rules: Seasonal Water Assignment Rules (WSS/2013/636, Version 4.02)' (2014)

Quiggin, John, 'Uncertainty, Risk and Water Management in Australia' in Lin Crase (ed), Water Policy in Australia: The Impact of Change and Uncertainty (Resources for the Future, 2008)

Sadler, B S, G W Mauger and Stokes R A, 'The water resource implications of a drying climate in south-west Western Australia' in G I Pearman (ed), Greenhouse: Planning for Climate Change (CSIRO Publishing, 1988)

Sadler, Brian, 'Climate Change and Water from the Sea' (2009)

$<$ http://www.connectedwaters.unsw.edu.au/articles/2009/03/climate-change-and-water-sea>

Sadler, Brian, 'Informed Adaptation to a Changed Climate State: Is South-Western Australia a National Canary?' (2005) <http://www.ioci.org.au/publications/cat_view/16-ioci-stage-2/33-generalpapers.html>

Schalk, Tara, Christine Hill and Noel Flavel, 'NSW Great Artesian Basin Water Market Assessment Pre and Post Auction ' (Paper presented at the 54th Annual Conference of the Australian Agricultural and Resource Economics Society, 2010)

Silberstein, R P et al, 'Climate change and runoff in south-western Australia' (2012) 475 Journal of Hydrology 441

Sinclair Knight Mertz, 'Assessment of groundwater licensing, metering and extraction estimation arrangements and techniques in Australia' (2012)

Sinclair Knight Mertz, 'Evolving issues and practices in groundwater-dependent ecosystem management' (National Water Commission, 2011)

Sinclair Knight Mertz, CSIRO and Bureau of Rural Sciences, 'Surface and/or Groundwater Interception Activities: Initial Estimates' (2010)

Skurray, James H., Ram Pandit and David J. Pannell, 'Institutional impediments to groundwater trading: the case of the Gnangara groundwater system of Western Australia' (2013) 56(7) Journal of Environmental Planning and Management 
Skurray, James H., E. J. Roberts and David J. Pannell, 'Hydrological challenges to groundwater trading: Lessons from south-west Western Australia' (2012) 412-413 Journal of Hydrology 256

Stocker, T.F. et al (eds), Climate Change 2013: The Physical Science Basis: Contribution of Working Group I to the Fifth Assessment Report of the Intergovernmental Panel on Climate Change (Cambridge University Press, 2013)

Sundareshan, Priyanka, 'Using the Transfer of Water Rights as a Climate Change Adaptation Strategy: Comparing the United States and Australia' (2010) 27(3) Arizona Journal of International and Comparative Law 911

Syme, G L, B E Nancarrow and J A McCreddin, 'Defining the components of fairness in the allocation of water to environmental and human uses' (1999) 57 Journal of Environmental Management 51

Tarlock, Dan, 'How Well Can Water Law Adapt to the Potential Stresses of Global Climate Change?' (2010) 14 University of Denver Water Law Review 1

Taylor, Richard G. et al, 'Ground water and climate change' (2012) 3(4) Nature Climate Change 322

Tindal, B., J. M. Arblaster and S Power, 'Attribution of the Late-Twentieth-Century Rainfall Decline in Southwest Australia' (2006) 19 Journal of Climate 2046

Van der Gun, Jac and Annukka Lipponen, 'Reconciling Groundwater Storage Depletion Due to Pumping with Sustainability' (2010) 2(11) Sustainability 3418

Vogwill, VIJ et al, 'PRAMS Scenario Modelling for Water Management of the Gnangara Groundwater Mound' (2008)

Water and Rivers Commission, 'Managing the Water Resources of the Gingin Groundwater Area, WA: Interim Sub-Regional Allocation Strategy' (2002)

Water Corporation, 'Annual Report 2013' (2013)

Water Corporation, Water Story: The Battle to Keep Perth Green (Water Corporation, 2007)

Water, Department of, 'Arrowsmith Groundwater Allocation Plan: Evaluation Statement 2010-2011' (2011)

Water, Department of, 'Operational Policy 5.01: Managing Water Reserved for Use by Drinking Water Service Providers' (2011)

Water, Department of, 'South West Groundwater Areas Allocation Plan' (2009)

Water Reform Implementation Committee, 'A Blueprint for Water Reform in Western Australia: Final Advice to the Western Australian Government' (2006)

Winterbourne, Katie, 'Obtaining Access to Water for Mining Purposes in Western Australia' (1997) 16 Australian Mining and Petroleum Law Journal 166

Yesertner, Cahit, 'Assessment of the declining groundwater levels in the Gnangara Groundwater Mound' (Department of Water, 2008)

Young, Michael D. and Jim C. McColl, 'Double trouble: the importance of accounting for and defining water entitlements consistent with hydrological realities' (2009) 53(1) Australian Journal of Agricultural and Resource Economics 19

Young, Mike, 'Sharing Groundwater: Options for the Introduction of Shares as a Means to Define Groundwater Entitlements in the South East of South Australia' (2005)

Zhou, Yangxiao, 'A critical review of groundwater budget myth, safe yield and sustainability' (2009) 370(1-4) Journal of Hydrology 207 
